

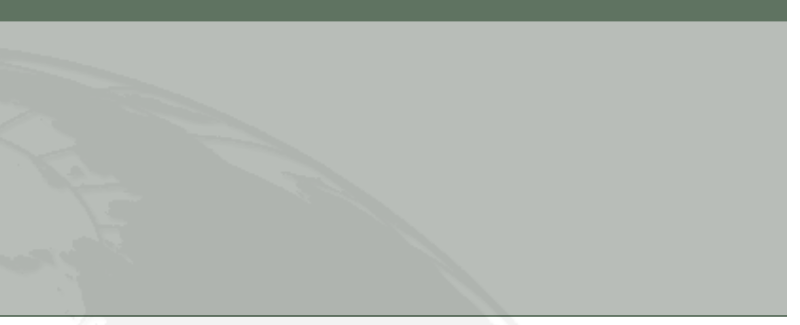

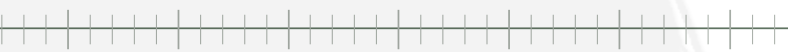




\section{Sodobni vojaški izzivi}

Contemporary Military Challenges

Znanstveno-strokovna publikacija Slovenske vojske

ISSN 2232-2825

UDK 355.5(479.4)(055)

December 2014 - 16/št. 4

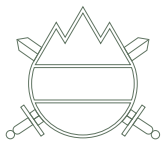

REPUBLIKA SLOVENIJA

MINISTRSTVO ZA OBRAMBO

GENERALŠTAB SLOVENSKE VOJSKE 


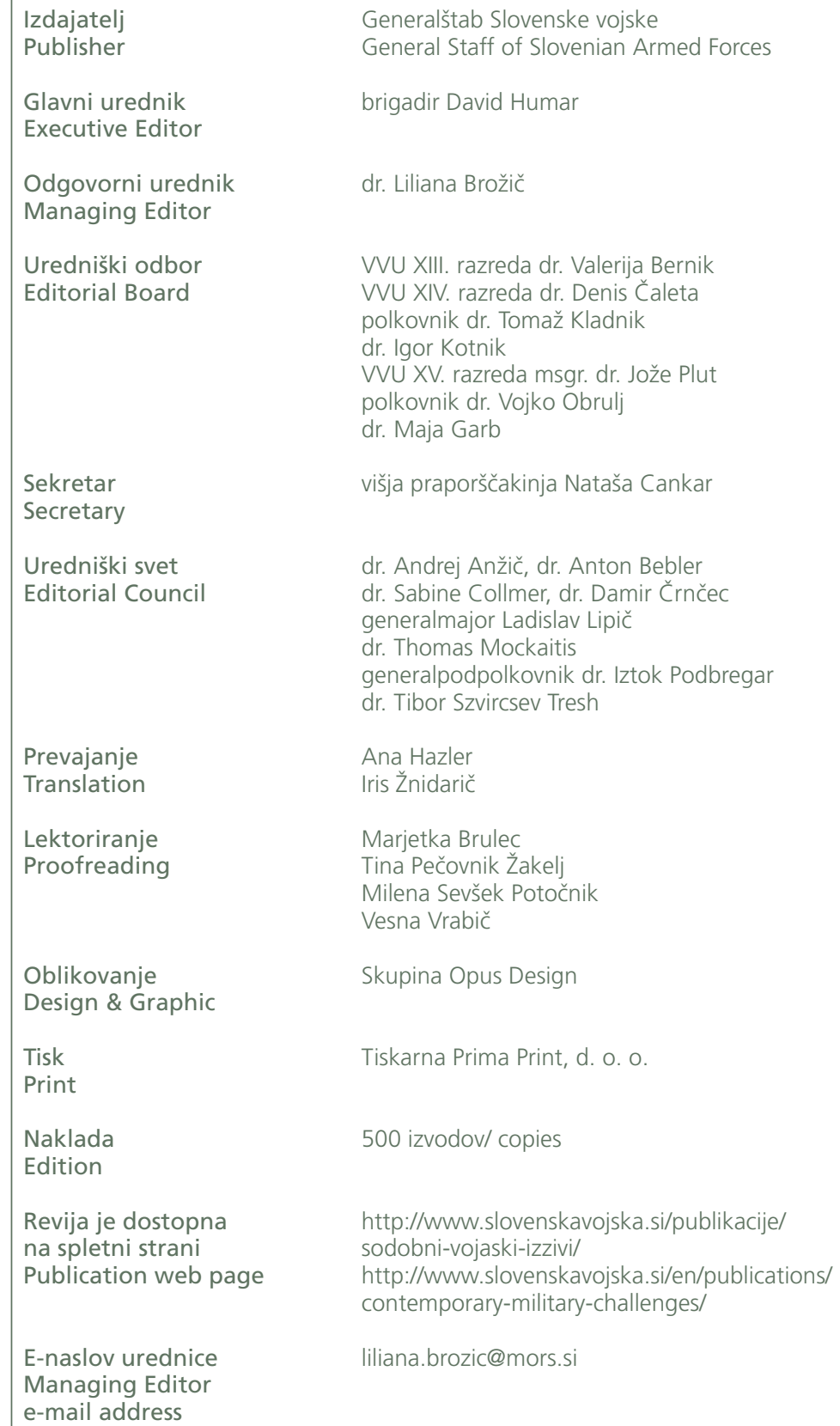

VVU XIII. razreda dr. Valerija Bernik VVU XIV. razreda dr. Denis Čaleta polkovnik dr. Tomaž Kladnik dr. Igor Kotnik VVU XV. razreda msgr. dr. Jože Plut polkovnik dr. Vojko Obrulj dr. Maja Garb

višja praporščakinja Nataša Cankar

dr. Andrej Anžič, dr. Anton Bebler dr. Sabine Collmer, dr. Damir Črnčec generalmajor Ladislav Lipič dr. Thomas Mockaitis generalpodpolkovnik dr. Iztok Podbregar dr. Tibor Szvircsev Tresh

Ana Hazler

Iris Žnidarič

Marjetka Brulec

Tina Pečovnik Žakelj

Milena Sevšek Potočnik

Vesna Vrabič

Skupina Opus Design

Tiskarna Prima Print, d. o. o.

$500 \mathrm{izvodov} /$ copies

http://www.slovenskavojska.si/publikacije/ sodobni-vojaski-izzivi/ http://www.slovenskavojska.si/en/publications/ contemporary-military-challenges/

liliana.brozic@mors.si

Prispevki, objavljeni v Sodobnih vojaških izzivih, niso uradno stališče Slovenske vojske niti organov, iz katerih so avtorji prispevkov.

Publikacija je uvrščena v bibliografsko zbirko podatkov COBISS.SI in PAIS International.

Articles, published in the Contemporary Military Challenges do not reflect the official viewpoint of the Slovenian Armed Forces nor the bodies in which the authors of articles are employed.

The publication is indexed in bibliography databases COBISS.SI and PAIS International. 


\section{OB STOTI OBLETNICI ZAČETKA PRVE SVETOVNE VOJNE - ALI SMO SE IZ KONFLIKTOV V ZADNJIH STO LETIH KAJ NAUČILI?}

»15. avgust 1916: Ob drugi uri zjutraj pade na naše levo krilo (5. kompanija) nekaj težkih min. Na naši strani dva mrtva in nekaj težko ranjenih. Od pete ure zjutraj je laška artilerija streljala na postojanke našega polka. Ogenj je bil zaradi težkih min bobneč."

Franjo Malgaj, rezervni poročnik 87. celjskega pešpolka, v: Franjo Malgaj, Vojni spomini 1914-1919, zbral in uredil generalmajor v pokoju Marijan F. Kranjc

\section{$100^{\text {TH }}$ ANNIVERSARY OF THE} BEGINNING OF WORLD WAR I HAVE WE LEARNED ANYTHING FROM THE CONFLICTS IN THE PAST 100 YEARS

»15 August 1916: At 02.00, a few heavy mines hit our left wing ( $5^{\text {th }}$ Company). Two dead and several heavily wounded on our side. Since 05.00 a.m., Italian artillery has been firing at our regiment's posts. Because of the mines, the fire was booming."

Franjo Malgaj, Second Lieutenant in Reserve, $87^{\text {th }}$ Celje Infantry Regiment from Franjo Malgaj: Vojni spomini 1914-1919, collected and edited by Major General (Ret.) Marijan F. Kranjc. 


\section{RECENZENTI/REFEREES}

Dr. Zvonimir Bratun

Dr. Damir Črnčec

Dr. Branimir Furlan

Dr. Gregor Garb

Dr. Mojca Pešec 


\section{VSEBINA}

CONTENTS

UVODNIK

OB STOTI OBLETNICI ZAČETKA PRVE SVETOVNE VOJNE ALI SMO SE IZ KONFLIKTOV V ZADNJIH STO LETIH KAJ NAUČIII?

9

Liliana Brožič

EDITORIAL

$100^{\text {TH }}$ ANNIVERSARY OF THE BEGINNING OF WORLD WAR I-

HAVE WE LEARNED ANYTHING FROM THE CONFLICTS IN THE PAST 100 YEARS

13

Uroš Tovornik ČAS OBLIKOVANJA NOVEGA SVETOVNEGA REDA THE TIME OF THE FORMATION OF A NEW WORLD ORDER

31

Valerija Bernik KEMIČNO OROŽE - POSEBNOST PRVE SVETOVNE VOJNE ALI ŠE DANES PRETEČA NEVARNOST

CHEMICAL WEAPONS - PARTICULARITY OF WORLD WAR I OR A STILL IMMINENT DANGER

51

Jože Rozman

VOJAŠKOGEOGRAFSKA RAZSEŽNOST DOBRUDŽE IN (SLOVENSKI)

PROSTOVOUCI NA TEM BOJIŠČU V PRVI SVETOVNI VOJNI

MILITARY GEOGRAPHICAL DIMENSION OF DOBROGEA AND (SLOVENIAN)

VOLUNTEERS IN THIS BATTLEFIELD IN WORLD WAR I 
71

Mircea Tănase

Viktor Potočnik

Tanja Kovač Kremžar

»MARKET GARDEN« - THE EPIC AND THE TRAGEDY OF ALLIED PARATROOPERS IN THE NETHERLANDS

»MARKET GARDEN - JUNAŠTVO IN TRAGEDIJA ZAVEZNIŠKIH PADALSKIH ENOT NA NIZOZEMSKEM

\section{5}

OBSEG IN KARAKTER SLOVENSKE VOJSKE

SLOVENIAN ARMED FORCES SIZE AND CHARACTER

105

VOJAŠKOMEDICINSKA OBVEŠČEVALNA DEJAVNOST Z OMEJENIMI VIRI NA PRIMERU MAJHNIH DRŽAV

MILITARY MEDICAL INTELLIGENCE WITH LIMITED RESOURCES

IN THE CASE OF SMALL COUNTRIES

123

Maja Garb

PROBLEMI VOJAŠKO-VARNOSTNEGA POGODBENIŠTVA V IRAKU IN AFGANISTANU

PROBLEMS OF MILITARY SECURITY CONTRACTORSHIP IN IRAQ

AND AFGHANISTAN

127

SLIKOVNO GRADIVO

PHOTOS

135

AVTORJI

AUTHORS

140

NAVODILA AVTORJEM ZA OBLIKOVANJE PRISPEVKOV

145

INSTRUCTIONS FOR THE AUTHORS OF PAPERS 


\section{UVODNIK}

\section{OB STOTI OBLETNICI ZAČETKA \\ PRVE SVETOVNE VOJNE - \\ ALI SMO SE IZ KONFLIKTOV \\ V ZADNJIH STO LETIH KAJ NAUČILI?}

Tak je naslov tokratne tematske številke, s katero smo želeli poudariti pomembno obletnico. Naš namen ni bil izdati številke na temo vojaške zgodovine, saj je naslov publikacije vendarle Sodobni vojaški izzivi. Kljub temu se nekaterim zgodovinskim temam in dejstvom nismo izognili. Brez proučevanja in predstavitve vsebinskega okvira ne bi mogli ugotavljati, ali smo se iz konfliktov v zadnjih sto letih kaj naučili.

Gre za dolgo in dinamično stoletje. Veliko je bilo napisanega o tem obdobju, še posebno z varnostnega in vojaškoobrambnega vidika. Prva in druga svetovna vojna sta bili zelo obsežni. Dosegli sta nepričakovane razsežnosti v političnem, varnostnem, obrambnem, ekonomskem, družbenem, geografskem in geopolitičnem smislu. Zaznamovali pa sta ga še dve drugi vojni, hladna vojna in vojna proti terorizmu. Ta je sčasoma prešla v boj proti terorizmu, v Sloveniji pa smo dosegli dogovor, da gre na tem področju za zoperstavljanje terorizmu.

Na naštete vojne so pomembno vplivali razvoj tehnologije, informatike, gradbeništva, logistike, inženirstva, letalstva, oborožitve, transporta in še bi lahko naštevali.

Veliko zanimivih posameznikov je vplivalo na razvoj dogodkov v tem obdobju. Vse se je začelo z Gavrilom Principom, ki je usodne nedelje 28. junija 1914 streljal na prestolonaslednika Franca Ferdinanda, Avstro-Ogrska pa se je zato pozneje odločila napasti Srbijo. Veliko imen se je nanizalo na časovni trak zgodovine, nekatera $\mathrm{s}$ pozitivnim, druga z negativnim predznakom. Slovence na tisti čas zagotovo najbolj spomni prvi slovenski general Rudolf Maister, čeprav nekatere generacije v šolah zanj še nikoli niso slišale. Časi se spreminjajo, prav tako naš pogled na zgodovinske spomine in dejstva. Zato je prav, da se nekaterih stvari, oseb in dogodkov spominjamo, jih analiziramo, ovrednotimo, vse zato, da bi se iz njih kaj naučili. Predvsem pa, da ne bi ponavljali vsega tistega, kar je zgodovina pokazala, da je bilo narobe, slabo, škodljivo za posameznika, narode, naravo, države ali svet. 
Na naše vprašanje, ali smo se v zadnjih sto letih kaj naučili, je Uroš Tovornik odgovoril s prispevkom z naslovom Čas oblikovanja novega svetovnega reda, $\mathrm{v}$ katerem trdi, da današnji varnostni problemi večinoma izvirajo iz odločitev, sprejetih na versajski mirovni konferenci, in iz poznejših dogodkov. Avtor v sklepu povzame, da je današnja geopolitična situacija bistveno drugačna od tiste pred sto leti ali pa ji je po drugi strani zelo podobna.

Valerija Bernik se je posvetila temi Kemično orožje-posebnost prve svetovne vojne ali še danes preteča nevarnost. V prispevku predstavi zgodovino uporabe različnih vrst kemičnega orožja, ki so ga sicer prvič preizkusili že avstro-ogrski vojaki na soški fronti v boju z italijanskimi nasprotniki. V nadaljevanju predstavi vse napore mednarodne skupnosti za preprečevanje, omejevanje in zaščito proti kemičnemu orožju.

Danes si je težko predstavljati, da bi kdo od Slovencev šel prostovoljno v vojno daleč stran od svoje domovine in se boril v pokrajini, ki leži na meji med Romunijo in Bolgarijo. O tej posebnosti piše Jože Rozman v prispevku Vojaškogeografska razsežnost Dobrudže in slovenski prostovoljci na tem bojišču v prvi svetovni vojni. Nekoč ozemlje hudih bojev je danes pomembno območje za zavezniške sile, ki rešujejo krizo v Ukrajini.

Mircea Tănase se je posvetil operaciji »Market garden« - junaštvu in tragediji zavezniških padalskih enot na Nizozemskem. Podrobno predstavi in analizira operacijo, ugotavlja, kaj je šlo po načrtih in kaj narobe, na koncu pa poudarja pomen obveščevalne dejavnosti za sedanjost in prihodnost.

Viktor Potočnik je napisal prispevek Obseg in karakter Slovenske vojske. Veliko se je pisalo splošnega o tem, koliko pripadnikov in kakšne enote naj ima Slovenska vojska. Avtor v prispevku pove po resnici. Njegov pregled in izračun sta zelo preprosta in jasna. Je med bralci kdo, ki se z njim ne strinja in je pripravljen to napisati?

Tanja Kremžar Kovač v prispevku z naslovom Vojaškomedicinska obveščevalna dejavnost z omejenimi viri na primeru majhnih držav ugotavlja, da gre pri tej podzvrsti obveščevalno-varnostne dejavnosti za pridobivanje podatkov o zdravstvenih in okoljskih nevarnostih ter o zdravstvenih zmogljivostih in sposobnostih na mednarodnem območju, kjer delujejo pripadniki oboroženih sil. Zakaj je tema pomembna in kako poteka v praksi, je opisala tudi iz svojih izkušenj.

Maja Garb je na podlagi prebranega dela Thomasa R. Mockaitisa Soldiers of Misfortune? napisala recenzijo $\mathrm{z}$ naslovom Problemi vojaško-varnostnega pogodbeništva v Iraku in Afganistanu.

S to številko končujemo leto pomembnih obletnic, kot smo poimenovali leto $2014 \mathrm{v}$ začetku in vabimo k pisanju in branju tem, ki smo jih razpisali za leto 2015 na naši spletni strani http://www.slovenskavojska.si/publikacije/sodobni-vojaski-izzivi/. 


\section{EDITORIAL}

\section{$100^{\text {TH }}$ ANNIVERSARY OF THE BEGINNING OF WORLD WAR I - \\ HAVE WE LEARNED ANYTHING FROM THE CONFLICTS IN THE PAST 100 YEARS}

With this thematic issue the editorial board wishes to commemorate this important anniversary. Our objective was not to discuss military history, for we, as the name says, deal with Contemporary military challenges. However, we cannot avoid mentioning certain military topics and facts, as it is rather difficult to assess what we have learnt from the conflicts in the past one hundred years without examining and presenting the framework of certain events.

It has been a long and dynamic century. A lot has been written about this period, especially from the security as well as military and defence aspects. World War One and Two were unexpectedly extensive in political, security, defence, economic, societal, geographical and geopolitical sense. The twentieth century was also marked by two other wars: the Cold War and the fight against terrorism. The latter was gradually renamed into combat against terrorism. In Slovenia, however, we came to an agreement that this area in fact refers to counter terrorism.

The aforementioned wars were strongly influenced by developments in various fields, such as technology, informatics, civil engineering, logistics, engineering, aviation, armament, transport and so on.

A lot of interesting individuals influenced the course of events in this period. It all started with Gavrilo Princip who fired at the heir to the throne Franz Ferdinand on that fatal Sunday, 28 June 1914. This eventually resulted in Austria-Hungary's decision to attack Serbia. A lot of names found their place on the historical timeline; some of them with a positive and others with a negative connotation. For Slovenians, the best symbol of that time is undoubtedly the first Slovenian General Rudolf Maister, even though some generations never even heard of him in school. The times are changing, and so are our views on certain historical memories and the facts related to them. It is therefore appropriate to remember certain things, persons and events, and it is 
also appropriate to analyse and to assess them in order to learn from them. Especially with the intent of not repeating that which is seen throughout the eyes of the history as wrongful, bad or harmful to an individual, nations, nature, states and the world.

As the answer to our question whether we have learnt anything in the past one hundred years, Uroš Tovornik prepared a paper titled The time of the formation of a new world order, in which he claims that modern security issues originate, in particular, from the decisions adopted at the Versailles Peace Conference and the events that followed. In the conclusion, the author sums up that modern geopolitical situation differs substantially from the one a hundred years ago or, on the other hand, resembles it very much.

In her paper Chemical weapons - particularity of World War I or a still imminent danger, Valerija Bernik takes us through the history of the use of different types of chemical weapons. The latter were first tested by the Austro-Hungarian soldiers on the Isonzo Front in combat with their Italian opponents. Further on she presents all efforts the international community invests in the prevention and limitation of the use of chemical weapons as well as in protection against them.

It is nowadays difficult to imagine that a Slovenian would voluntarily engage in a war far from their homeland and fight in the region that lies on the border between Romania and Bulgaria. Jože Rozman writes about this particularity in his paper titled Military geographical dimension of Dobrogea and (Slovenian) volunteers in this battlefield in World War I. What was once a territory where severe combats took place, is now an area important for the allied forces combating the crisis in Ukraine.

In the paper titled Market Garden - the epic and the tragedy of allied paratrooper units in the Netherlands, Mircea Tănase presents and analyses the mentioned allied operation in World War One in detail, assessing what went according to plans and what went wrong. Tănase concludes the paper by stressing the importance of intelligence both in the present and in the future.

Viktor Potočnik writes about Slovenian Armed Forces size and character. A lot has already been written, in general, about how many members and which types of units the Slovenian Armed Forces should have. In this paper, the author confronts us with facts. His overview and the calculations are very simple and transparent. Is there anyone among the readers who does not share his opinion and would be willing to write an article about it?

In her paper titled Military medical intelligence with limited resources in the case of small countries, Tanja Kremžar Kovač states that essential to this sub-type of intelligence and security activities is the acquisition of data on medical and environmental hazards and the medical capabilities in the international area in which members of the armed forces are engaged. Integrating her experience in the paper, the author also explains why this is an important topic and how this activity takes place. 
Maja Garb read the book of Thomas R. Mockaitis Soldiers of Misfortune? and wrote a peer review titled The challenges of military and security contracting in Iraq and Afghanistan.

With this issue, we conclude the year of important anniversaries, as we have named the year 2014 at the very beginning. We invite you to write on and read about the topics for which we have prepared an open invitation for articles for 2015, which is published on our website http://www.slovenskavojska.si/en/publications/. 


\section{ČAS OBLIKOVANJA \\ NOVEGA SVETOVNEGA REDA}

\section{THE TIME OF THE FORMATION \\ OF A NEW WORLD ORDER}

Povzetek Članek podaja analizo sprememb v strateškem varnostnem okolju od prve svetovne vojne do danes, ki zaznamuje začetek novega svetovnega reda, ter identificira ponavljajoče se vzorce in zakonitosti $\mathrm{v}$ celotnem obdobju, ki so se pojavili kot posledica prve svetovne vojne oziroma dogodkov takoj po njej, in njihovo preslikavo v današnji čas. Avtor trdi, da današnja varnostna vprašanja izvirajo predvsem iz odločitev, sprejetih na versajski mirovni konferenci, in iz dogodkov, ki so ji sledili. Druga svetovna vojna in hladna vojna sta večinoma logični posledici prve svetovne vojne. Ozemeljski spori in mnogi zamrznjeni konflikti v Srednji in Vzhodni Evropi so se ponovno razplamteli takoj po padcu Berlinskega zidu. To območje je ponovno polje geopolitične igre, v katero se vrača združena Nemčija, ki postaja dominantna politična sila v Evropi. S svetovno finančno krizo, ki je oslabila Evropsko unijo, strateško preusmeritvijo ZDA v vzhodno Azijo in na Pacifik ter z nedavno spremembo v varnostnem okolju zaradi krize v Ukrajini in odmika Rusije od Zahoda se nakazujejo težnje strateških premikov v varnostnem okolju. Ali bo to privedlo do novega svetovnega reda, pa je odvisno od naslednjih korakov strateških igralcev in od tega, kakšne so njihove pridobljene in predvsem ponotranjene izkušnje iz preteklega stoletja, ki bi pomagale preprečiti napake, narejene v tem obdobju.

Ključne

Novi svetovni red, prva svetovna vojna, geopolitika, mednarodne organizacije, besede nova Evropa, Nato, Rusija, Nemčija.

Abstract The article analyses the continuous change in the geostrategic security environment in Europe since the beginning of the World War I, which marked the beginning of a new world order. It walks us through the major strategic shifts in Europe during the $20^{\text {th }}$ century as a result of World War I in order to identify repetitive patterns and to see how they come into play today. The author argues that the $21^{\text {st }}$ century strategic issues are rooted in the decisions taken at the Versailles Peace Conference and that World War II and the Cold War were, in most parts, the logical consequences 
of the Great War. Territorial disputes and numerous frozen conflicts, mainly in the Central and Eastern Europe broke up immediately after the fall of the Berlin wall. This region, has been once and again the territory that sparks major geopolitical changes in Europe. Today, the very same region is again the point of departure of a new strategic game, with Germany at its core as the rising dominant power in Europe. The outbreak of the global financial crisis in 2008, which weakened the European Union together with the US pivoting to East Asia and Pacific, and the changed security environment in Europe due to the crisis in Ukraine and Russian geopolitical shift away from Europe, an emerging global strategic shift is shaping. The future will show how and if the strategic players will use the lessons of the past century in order to avoid making the same mistakes.

Key words New world order, World War I, geopolitics, international organizations, New Europe, NATO, Russia, Germany.

Uvod S prvo svetovno vojno je človeštvo pravzaprav vstopilo v 20. stoletje. Če francoska revolucija konec 18. stoletja in pomlad narodov leta 1848 pomenita formalni konec fevdalizma v Evropi, predstavlja prva svetovna vojna njegov geopolitični konec. Z njo se je začelo novo obdobje, ki ga živimo še danes. Dvajseto stoletje se je pravzaprav začelo s prvo svetovno vojno, saj so bili vsi poznejši dogodki v resnici posledica te vojne (povzeto po: MacMillan, 2003) in novega svetovnega reda, oblikovanega na pariški mirovni konferenci v Versaillesu leta 1919.

Bistveni dejavnik, ki je privedel do te velike vojne, je bila, kot ugotavlja tudi Simms, združitev Nemčije v drugi polovici 19. stoletja, ki je začela ogrožati ravnovesje sil, oblikovano po koncu napoleonovskih vojn (Simms, 2013). Ta dogodek je povzročil pretres na evropskem geopolitičnem zemljevidu, saj je dodal igri novega igralca, ki je hipoma zmagal v francosko-nemški vojni v letih 1870 in 1871 (povzeto po: Encyclopedia Britannica, 2014) ter postopoma začel ogrožati interese starih kolonialnih sil v Evropi in svetu. Ta zmaga in skokovit vzpon nemške industrijske proizvodnje, ki je potrebovala svetovno tržišče, sta povzročila strah predvsem v kolonialnih velesilah Franciji in Veliki Britaniji ter v Ruskem carstvu. Njihov odgovor na nemški vzpon je bil samodejen, rezultat pa je bilo oblikovanje vojaškega zavezništva antanta ( $f r$. Entente Cordiale). Na nasprotni strani sta se poleg Nemčije znašla še dva usihajoča večnacionalna imperija, habsburški in otomanski, ki sta navznoter doživljala implozijo, situacija strateškega vkopavanja pa jima je ustrezala predvsem za notranjepolitično konsolidacijo.

Razvoj dogodkov v prejšnjih sto letih avtor označuje kot nenehno geostrateško igro ničelne vsote. Ta se uporablja v teoriji iger, nanaša pa se na igro, v kateri en igralec zmaga, drugi pa izgubi, skupni rezultat igre pa je vedno nič (povzeto po: Ferguson, 2014). Nekako se zdi, da se danes svetovna igra ponovno vrača na izhodiščne položaje pred ubojem avstro-ogrskega prestolonaslednika Franca Ferdinanda v Sarajevu junija 1914, ki sicer ni bil vzrok za vojno, temveč njen sprožilec. Takrat, 
podobno kot danes, je potekal boj za nadzor nad Srednjo in Vzhodno Evropo (povzeto po: Mackinder, 1919). Slednja po Mackinderju ${ }^{1}$ že spada v tako imenovano strateško osrčje (angl. Heartland) (povzeto po: Mackinder, 1919). Natanko stoletje pozneje, leta 2014, je svet prvič po koncu hladne vojne in Natovem bombardiranju Zvezne republike Jugoslavije spomladi leta 1999 ponovno postavljen pred mogoče konflikte velikih razsežnosti v Vzhodni Evropi. Vprašanje je, ali je dovolj ponotranjil pridobljene izkušnje iz 20. stoletja in bo tako zmožen premostiti skušnjave sodobnih varnostnih izzivov.

Namen tega članka je prispevati k širši razpravi o posledicah velike vojne na razvoj dogodkov v 20. stoletju ter odpreti vprašanje, kje smo po sto letih. V okviru tega sicer širokega vprašanja se bomo osredotočili predvsem na dve vprašanji:

- katere so glavne varnostno-politične spremembe, ki jih je prinesla prva svetovna vojna, s čimer se je vzpostavil, kot je to poimenoval takratni predsednik ZDA Wilson ${ }^{2}$, nov svetovni red;

- kako zgodovinsko izkušnjo iz preteklih sto let preslikati v današnjo svetovno stvarnost in ali se svetovni red danes oblikuje na novo.

Izhajali bomo iz teh parametrov: Evropa in svet sta se s prvo svetovno vojno korenito spremenila. Vzroke za drugo svetovno vojno je mogoče iskati v rezultatih in posledicah prve svetovne vojne in sklepov, sprejetih na versajski mirovni konferenci v Parizu. Ustanovitev Društva narodov kot predhodnika večine današnjih mednarodnih organizacij, utemeljenih na načelih OZN, je temelj današnje evropske (in svetovne) varnostno-politične ureditve. Danes je mogoče iskati primerjave z dogodki, ki so se pojavili po letu 1918 in se obdobno ponavljajo. Dogodki, ki se dogajajo od svetovne finančne krize leta 2008, nakazujejo težnje po strateških spremembah. To lahko posledično vodi do oblikovanja novega svetovnega reda.

\section{POSLEDICE PRVE SVETOVNE VOJNE}

\subsection{Kaj se je spremenilo s prvo svetovno vojno}

Poleg geopolitične spremembe v Evropi avtor prispevka med tri bistvene dejavnike, ki so usmerjali razvoj 20. stoletja, prišteva tudi ideološkega. Tretji dejavnik je vstop ZDA v vojno leta 1917 in posledično njihova vojaška in politična zavzetost na stari celini kljub tako imenovani Monrojevi doktrini, ki poudarja pomen nevmešavanja evropskih sil v zadeve Latinske Amerike, v zameno pa daje zavezo o nevmešavanju ZDA v evropske (The Monroe doctrine, 1823).

\footnotetext{
Sir Halford John Mackinder, eden utemeljiteljev moderne geopolitične misli, avtor teorije o osrčju (Heartland) Sodeloval je na mirovni konferenci v Versaillesu leta 1919 in istega leta izdal knjigo z naslovom Democratic Ideals and Reality. Njegova zamisel o vzpostavitvi tamponskih držav med Nemčijo in Rusijo je bila po konferenci uresničena. Leta 1924 je na podlagi izkušenj iz prve svetovne vojne objavil teorijo o atlantski skupnosti, ki se je materializirala po koncu druge svetovne vojne v vojaški različici, v Natu.

2 Wodrow Wilson je bil 28. predsednik ZDA. Predsedoval jim je v letih od 1913 do 1921. Državo je popeljal v prvo svetovno vojno na strani zmagovite antante. Bil je ena najpomembnejših osebnosti na versajski mirovni konferenci leta 1919 in med drugim velik zagovornik pravice do samoodločbe narodov ter eden očetov Društva narodov, za katero je menil, da je temelj novega svetovnega reda.
} 
Z nastankom novih držav na pogoriščih starih imperijev je v geopolitičnem smislu nastal prazen prostor, ki je zahteval novo ravnotežje sil, predvsem v Srednji in Vzhodni Evropi. Ta del sveta je s koncem prve svetovne vojne postal območje za širjenje interesov in to ostal še vse 20. stoletje. Ključna država med obema vojnama na tem območju je bila za Friedmana Poljska, ki je z Romunijo, s katero je imela med obema vojnama ozemeljski stik, predstavljala zid med Baltskim in Črnim morjem, med takrat boljševistično Sovjetsko zvezo in zahodnim svetom (povzeto po: Friedman, 2014). Obe državi sta bili zaveznici Francije in Velike Britanije.

Z drugo svetovno vojno se je ta klasična geopolitična konstelacija spremenila in dobila primarno ideološko razsežnost. Nastavki zanjo so začeli nastajati že sredi prve svetovne vojne, z oktobrsko revolucijo leta 1917 v takratni carski Rusiji. Cesarska Nemčija si je zelo prizadevala zanetiti revolucijo, ki bi Rusijo izločila iz vojne, da bi vse svoje sil lahko premestila na zahodno bojišče in odločila vojno sebi v prid. To se je sicer zgodilo, saj je Rusija po tem, ko so 7. novembra 1917 boljšseviki prevzeli oblast, sklenila premirje s centralnimi silami in 3. marca $1918 \mathrm{v}$ Brest-Litovsku podpisala mir (The Treaty of Brest-Litovsk, 1918).

Vstop ZDA v vojno na strani antante leta 1917 je prevesil zmago na stran antantnih sil. Takrat se je prvič zgodilo, da so ZDA vojaško posredovale v Evropi. Prav tako so kot ena izmed zmagovitih držav dejavno oblikovale novo povojno geografsko podobo Evrope. Ne glede na to, da so se ZDA po koncu Wilsonovega mandata umaknile iz Evrope, ostaja dejstvo, da so se v drugi svetovni vojni ponovno pridružile Veliki Britaniji in Franciji proti centralnim silam, ki so jih sestavljale Nemčija, Italija in Japonska, ki so podpisale trojni pakt (The Three-Power Pact, 1940). Od takrat so ZDA vojaško in politično prisotne v Evropi.

Države udeleženke pariške mirovne konference so junija 1919 podpisale listino, s katero so se obvezale, da ustanovijo Društvo narodov. To je bila mednarodna organizacija, ki je nastala $\mathrm{v}$ upanju, da bo konflikte preprečevala s spodbujanjem politike razoroževanja, odprte diplomacije, mednarodnega sodelovanja in $\mathrm{s}$ sankcijami, ki bi vojno naredile neatraktivno (The Versailles Treaty, Part I., 1919). Društvo narodov je nehalo delovati po koncu druge svetovne vojne, ko so bili ustanovljeni Združeni narodi, čeprav je bilo pravnoformalno vanje vključeno kot njihov predhodnik (UN, 1945).

\subsection{Travma druge svetovne vojne}

Drugo svetovno vojno je po avtorju prispevka mogoče gledati v luči rezultata in posledic prve. Vojne reparacije, izčrpana industrija, politična nestabilnost in izguba ozemelj so bile za Nemčijo travmatična izkušnja. Po drugi strani je takratna Kraljevina Italija pričakovala višjo nagrado za vstop v vojno na strani antante ${ }^{3}$. Poleg tega se je pojavila še Sovjetska zveza, nov ideološki element, ki je po končani državljanski

3 Posledica je t. i. marš na Rim 28. oktobra 1922 in prihod fašistov (in Benita Mussolinija) na oblast. 
vojni v začetku dvajsetih let grozila z izvozom revolucije na zahod ${ }^{4}$ Svetovna gospodarska kriza leta 1929 je takšne nestabilne razmere le še poslabšala in januarja 1933 v Nemčiji povzročila prihod nacistov na oblast, španska državljanska vojna pa se je tik pred začetkom druge svetovne vojne dogajala na območju, na katerem sta se prvič spopadli dve nasprotujoči si ideologiji, nacizem in komunizem (povzeto po: Simms, 2013).

Evropa je iz druge svetovne vojne izšla kolektivno zelo oslabljena. Centralne sile so bile poražene, Francija kot zmagovalka prve svetovne vojne je vojno leta 1940 sicer vojaško zgubila, a se je vanjo vrnila kot zmagovalka, predvsem zaradi pomoči zaveznikov. Velika Britanija se je obdržala predvsem zaradi svoje geografske lege, vojna pa se je obrnila v njeno korist po vstopu ZDA v vojno. Kot pravi Simms, je Evropa, vključno s starimi kolonialnimi silami, predvsem pa Nemčija, po koncu druge svetovne vojne leta 1945 in s hkratnim začetkom hladne vojne v resnici postala potencialno vojskovališče dveh novih velesil, ZDA in Sovjetske zveze, ki sta si razdelili interesna območja na stari celini. To je trajalo do konca hladne vojne leta 1990, ki se je končala tam, kjer se je tudi začela, v Nemčiji (povzeto po: Simms, 2013). Evropske države so po dveh svetovnih vojnah prvič izgubile vodilno vlogo v svetovni politiki in prišle pod območje vpliva tretjih (zunajevropskih) sil. Prišel je čas za gradnjo novih, nadnacionalnih temeljev, ki bi to izgubo nadomestili.

\subsection{Mednarodne organizacije kot posebnost 20. stoletja}

Ustanavljanje mednarodnih organizacij po letu 1945 je nova razsežnost v političnem razvoju človeštva (še posebno Evrope). Po izkušnjah dveh svetovnih vojn in soglasju zmagovalcev v drugi svetovni vojni, da je treba ustanoviti svetovno mednarodno organizacijo, ki bo vključevala vse svetovne države in bo, drugače kot predvojno Društvo narodov, vplivala na države, ki ne bodo spoštovale mednarodnega reda, so bili 24. oktobra 1945 ustanovljeni Združeni narodi. Od ustanovitve so skupaj s specializiranimi agencijami in drugimi povezanimi organizacijami temelj mednarodnih miru in varnosti (UN, 2014).

Ustanovna listina Združenih narodov, posebno njen 51. člen, je služila kot pravna podlaga za ustanovitev regionalnih varnostnih organizacij (UN Charter, 1945), kot sta Organizacija Severnoatlantske pogodbe (v nadaljevanju Nato), ustanovljena leta 1949 (Nato, 1949), in Varšavski sporazum o prijateljstvu, sodelovanju in vzajemni pomoči (v nadaljevanju Varšavski pakt), ustanovljen leta 1955 ter razpuščen leta 1991. Varnostni organizaciji sta odražali takratno hladno vojno, ravnotežje sil, temelječe na dveh velesilah, ZDA in Sovjetski zvezi (Nato, 2014). Bistveno je to, da sta obe velesili postavili pravila igre in igro vodili tudi znotraj Združenih narodov.

Zahodnoevropske države so v obdobju po drugi svetovni vojni pospešeno izgubljale vpliv, ki so ga imele pred njo. Ta proces se je začel že po prvi svetovni vojni, v obdobju hladne vojne pa je bil v boju za svetovna vplivna območja med dvema velesilama

4 Revolucionarno vrenje se je na koncu vojne najradikalneje pojavilo v Nemčiji, Avstriji in na Madžarskem. 
še hitrejši. Evropske države so s poglobljenim gospodarskim sodelovanjem želele preseči nekdanje politične, gospodarske in vojaške napetosti, zato so ustanovile tri nadnacionalne organizacije ${ }^{5}$, ki so se leta 1967 združile v Evropsko gospodarsko skupnost (EU, 1967). Ta skupnost je bila predhodnica današnje Evropske unije, ki je leta 1993 nastala na podlagi sporazuma iz Maastrichta (EU, 1992).

Za Evropo je pomembna še Organizacija za varnost in sodelovanje v Evropi (OVSE), ki je prav tako nastala po načelih Ustanovne listine OZN. Leta 1975 je njena predhodnica Konferenca o varnosti in sodelovanju v Evropi sprejela Helsinško sklepno listino, v kateri so se države med drugim zavezale, da bodo spoštovale nedotakljivost mednarodno priznanih meja (pogosto oblikovanih na rezultatih versajske mirovne konference in po drugi svetovni vojni), suverenost držav podpisnic, ne bodo grozile drugim članicam, uporabljale sile proti njim ali se vmešavale v notranje zadeve drugih držav, spoštovale bodo pravico do samoodločbe narodov ter $\mathrm{v}$ dobri veri izpolnjevale obveznosti, ki izhajajo iz mednarodnega prava (OSCE, 2013).

\section{OBDOBJE GEOSTRATEŠKE TRANZICIJE}

\subsection{Konec hladne vojne in začetek tranzicijskega obdobja}

Hladna vojna se je končala s padcem Berlinskega zidu jeseni 1989, združitvijo obeh Nemčij (vzhodne in zahodne) leta 1990 ter razpustitvijo Varšavskega pakta julija 1991 in Sovjetske zveze decembra istega leta (Nato, 2014). Sovjetska zveza je od konca prve svetovne vojne poosebljala enega svetovnih centrov politične in predvsem ideološke moči, po koncu druge svetovne vojne pa tudi eno izmed dveh vojaških velesil. S padcem Berlinskega zidu se je to spremenilo.

Hkrati s propadom komunizma, ki je bil uveden v državah Srednje Evrope po drugi svetovni vojni, sta razpadli tudi večnacionalni državi, ki sta nastali po prvi svetovni vojni (Jugoslavija 1991 in Češkoslovaška 1993). Geostrateški prostor se je v tem obdobju spremenil. Na območju Srednje in Vzhodne Evrope je nastalo več novih majhnih držav, ki so začele definirati svoj strateški prostor v Evropi. Rešitev so našle v pridružitvi h kontinentalni ekonomsko-politični skupnosti - Evropski uniji in čezatlantski varnostni skupnosti - Natu. Kot ugotavlja Simms, sta s perspektivo o članstvu v obeh organizacijah ta dva projekta uspela združiti države vzhodnega bloka, tako ekonomsko kot politično in varnostno (povzeto po: Simms, 2013). Avtor meni, da se je s tem zmanjšala možnost morebitnih konfliktov v Srednji in Vzhodni Evropi, hkrati pa sta se obe organizaciji razširili v zahodni del strateškega jedra (po Mackinderju).

Po razpadu Sovjetske zveze leta 1991 se je prehodno obdobje začelo tudi v Ruski federaciji, zaznamuje ga predsedovanje Borisa Jelcina. Dejstvo je, da se je v

Skupnost za premog in jeklo leta 1952, Evropska gospodarska skupnost in Evropska skupnost za atomsko energijo (Euratom), obe 1958. 
devetdesetih letih prejšnjega stoletja Rusija začela odpirati proti zahodu. Hkrati je začela osrednja moč Moskve slabeti na račun federalnih enot in regij. Rusija tistega obdobja je doživljala več političnih konfliktov, ki so dosegli vrhunec oktobra 1993, ko je Jelcin z vojsko napadel parlament (Dumo), kar se je zgodilo prvič po letu 1917. Po zasedbi parlamenta je bila v kratkem obdobju sprejeta nova ustava, ki je predsedniku dajala široka pooblastila in uvedla predsedniški sistem. Simms ugotavlja, da je Rusija tudi vojaško doživljala neuspehe, še posebno ob porazu v prvi čečenski vojni leta 1996 (povzeto po: Simms, 2013). Obdobje tranzicije se je v Rusiji v resnici končalo leta 2000 z izvolitvijo Vladimirja Putina, kar avtor razloži v nadaljevanju.

\subsection{Vstop v 21. stoletje in nastanek nove Evrope}

Vstop v 21. stoletje so po avtorjevem mnenju zaznamovali teroristični napadi v ZDA septembra 2001, kot posledica tega pa tudi vojni v Afganistanu 2001 in Iraku 2003. Dejstvo je, da so ZDA vse prvo desetletje pozornost v zunanji in obrambni politiki namenjale predvsem povračilnim ukrepom za teroristične napade v New Yorku in Washingtonu. Za posredovanje v Afganistanu v začetku oktobra 2001 sicer niso imele soglasja Varnostnega sveta OZN, a je bila intervencija pod vodstvom $Z_{D A}^{6}$ širše razumljena kot legitimna oblika samoobrambe, ki je skladna z Ustanovno listino OZN. Boji so bili končani sredi decembra, nekaj dni za tem pa je Varnostni svet OZN odobril uvedbo misije za podporo prehodni afganistanski vladi za pomoč pri ohranjanju miru (Isaf) ${ }^{7}$. Isaf je po napadu na Irak avgusta 2003 prešel pod poveljstvo Nata (Nato, 2014).

Drugače pa je bilo s posredovanjem ZDA v Iraku leta 2003. ZDA so v Varnostnem svetu dosegle sprejetje Resolucije št. 1441, ki je režimu Sadama Huseina dala zadnjo možnost, da izpolni mednarodne obveznosti za nadzor oborožitve (UN, 2002) ${ }^{8}$. ZDA so dokazovale, da Irak tega ni storil in da ima na voljo orožje za množično uničevanje (kar se je izkazalo za neresnično), zato so spomladi 2003 vojaško posredovale ${ }^{9}$ skupaj s tako imenovano koalicijo voljnih ${ }^{10}$.

Vojaškemu posredovanju v Iraku sta nasprotovali najpomembnejši članici EU Francija in Nemčija (povzeto po: The Guardian, 2003). Prvič po drugi svetovni vojni se je zgodilo, da je Nemčija odkrito nasprotovala zunanjepolitični odločitvi ZDA. Tedanji sekretar za obrambo Rumsfeld je zavezništvo Francije in Nemčije poimenoval stara Evropa, ki se od nove Evrope razlikuje po tem, da ne podpira

${ }^{6}$ ZDA so se pridružile še Velika Britanija, Avstralija in Severno zavezništvo (kot opozicijske sile, ki so se bojevale proti Talibskemu režimu v Afganistanu).

International Security Assistance Force (ISAF).

8 Resolucija VS OZN 1441 med drugim prepoznava grožnjo mednarodnemu miru in varnosti, ki jo predstavlja Irak zaradi neizpolnjevanja obveznosti, ki izhajajo iz predhodnih resolucij (ki se nanašajo na prvo vojno v Iraku $v$ začetku 90. let), proliferacije orožja za množično uničevanje in raket dolgega dosega.

9 Povod za napad je bila ocena obveščevalnih služb, da ima Irak orožje za množično uničevanje. Vojni so nasprotovale Francija, Nemčija in Rusija ter večina arabskih držav.

${ }^{10}$ Koalicijo voljnih je sestavljalo 48 držav, od katerih so štiri (ZDA, Združeno kraljestvo, Avstralija in Poljska) prispevale svoje vojaške enote. 
odločitve, ki je ključna za ZDA (povzeto po: Baker, 2003). Z novo Evropo je Rumsfeld označil države Srednje in Vzhodne Evrope, od katerih so Poljska, Češka in Madžarska vstopile v Nato leta 1999, sedem preostalih (Estonija, Latvija, Litva, Slovaška, Slovenija, Romunija in Bolgarija) pa jim je sledilo leta 2004. Države, ki so si prizadevale za članstvo v Natu ${ }^{11}$, so v začetku februarja 2003 podpisale dokument, ki ga označujemo kot vilniuško izjavo, v katerem so podprle namero ZDA po vojaškem posegu v Iraku (povzeto po: Gherghisan, 2003).

Rumsfeldova nova Evropa se je pojavila kot nov geostrateški pojem, ki od tega trenutka, formalno pa z drugo razširitvijo Nata in vstopom teh držav v EU spomladi 2004, vključuje nekdanje ozemlje Varšavskega pakta ${ }^{12}$, s katerim se je Evropa varnostno in politično zaokrožila ter približala ruskim mejam in kamor se je preselilo evropsko geopolitično težišče (povzeto po: Baker, 2003).

\subsection{Svetovna finančna kriza in njene posledice}

Z bankrotom bančnega giganta iz ZDA Lehman Brothers septembra 2008 je bilo dokončno jasno, da se je svet znašel v globalni finančni krizi. Kriza, ki se je nakazala že leta 2007 s krizo nepremičninskega trga, je nastala kot posledica dolgoletnih finančnih špekulacij na svetovnih finančnih trgih. V ZDA je sprožila recesijo in se kmalu razširila po vsem svetu ter se v Evropi spremenila v krizo evra (povzeto po: The Economist, 2013). To je najgloblja finančna kriza po svetovni depresiji, ki se je začela deset let po koncu prve svetovne vojne, leta 1929, in trajala skoraj do druge svetovne vojne. Evropa in svet sta bila nanjo nepripravljena. Prva žrtev krize v Evropi je bila Grčija, ki se je morala spoprijeti s kombinacijo strukturnih pomanjkljivosti v gospodarstvu ter z visokimi proračunskimi primanjkljaji (povzeto po: Nelson, Belkin, Mix, 2011). Podobne težave so imele še Portugalska, Irska, Italija in Španija. Težave z odplačevanjem obveznosti so vplivale tudi na evro, ki je postal zelo nestabilen (povzeto po: The Economist, 2013).

Odgovori na krizo evra se kažejo v manjšanju javnih izdatkov v večini držav članic. Posledično to pomeni manj javnih sredstev za socialo, zdravstveno zavarovanje, kulturo in druge javne službe, ki so po drugi svetovni vojni, predvsem v Zahodni Evropi, predstavljale model za države blagostanja. To jim je po prepričanju avtorja dajalo politično privlačnost, kar je po eni strani prispevalo h krhanju režimov $\mathrm{v}$ vzhodnem bloku in k želji po pridružitvi držav Srednje in Vzhodne Evrope temu modelu zahoda, po drugi pa je prispevalo k povečanju imigracije iz neevropskih držav - nekdanjih kolonij, predvsem iz Severne Afrike in z Bližnjega vzhoda.

Prav tako tudi obrambnim izdatkom pri manjšanju proračunov ni bilo prizaneseno (Nato, 2014). Države so se odzvale različno. V zahodnem delu Evrope so se praviloma odločale za zmanjševanje obrambnih sil in določanje, katere zmogljivosti imajo prednost. Zanimiv je podpis pogodbe o strateškem partnerstvu, ki sta

\footnotetext{
"I To so bile: Albanija, Bolgarija, Hrvaška, Estonija, Latvija, Litva, Makedonija, Romunija, Slovaška in Slovenija.

${ }^{12}$ Razen Slovenije ter Hrvaške in Albanije. Slednji sta v Nato vstopili leta 2009.
} 
jo podpisali Francija in Velika Britanija leta 2010, v kateri sta se sporazumeli o tesnejšem obrambnem sodelovanju. Posebna pozornost v pogodbi je namenjena testiranju novih jedrskih zmogljivosti, vzdrževanju in servisiranju sedanjih jedrskih zmogljivosti obeh držav ter souporabi letalonosilk (UK-France Treaty, 2010). Podpis pogodbe je bil v Veliki Britaniji predstavljen kot ukrep za učinkovito zmanjšanje stroškov v obrambnem sistemu, vendar obenem daje vtis strateškega približevanja obeh držav.

Med pomembnimi posledicami finančne krize v Evropski uniji sta v notranjepolitičnem dogajanju naraščanje evroskepticizma in pojav skrajnih (protievropskih in protipriseljenskih) političnih strank, tako na volitvah v evropski parlament (2014 V primerjavi z volitvami iz leta 2009) kot na nacionalnih volitvah (povzeto po: The Economist, 2014). Še posebno povzročajo skrbi težnje v največjih državah, kot sta Francija (Narodna fronta voditeljice Marine Le Pen) in Velika Britanija (stranka protievropsko naravnanega politika Nigela Faragea, UKIP), v katerih se je evroskepticizem, podžgan s finančno krizo, odrazil v obljubi britanskega predsednika vlade Davida Camerona, da leta 2017 razpiše referendum o izstopu Velike Britanije iz Evropske unije (povzeto po: The Economist, 2013).

\section{GEOSTRATEŠKI PREMIKI}

\subsection{Nova Evropa kot mejno ozemlje za Zahodno Evropo}

V zadnjem času, posebno pa od leta 2014, se prostor nove Evrope ponovno pojavlja kot območje nove geopolitične igre, tokrat med ZDA in Nemčijo na eni strani in vojaško revitalizirano Rusijo ${ }^{13}$ na drugi. Rusija je po ocenah Inštituta za strateške študije iz Londona $\mathrm{v}$ letih od 2008 do 2013 povečala obrambni proračun za 31 odstotkov (povzeto po: The Japan Times, 2014). Na pojav nove geopolitične igre v svojih razmišljanjih namiguje tudi geostrateg George Friedman iz Stratforja. Po Friedmanu (Friedman, 2014) se je s pojavom finančne krize v Evropi spremenil predvsem položaj Nemčije, ki zaradi gospodarske moči ponovno preračunava svojo prihodnjo vlogo v Evropi. Še posebno zaradi strateške preusmeritve ZDA v vzhodno Azijo (US Strategic Guidance, 2012) ${ }^{14}$, s čimer se je manevrski prostor za igro v Evropi razširil. Vanjo je poleg Nemčije odločneje vstopila tudi Rusija. Tradicionalno sta ti dve državi (in habsburški imperij do prve svetovne vojne) odločali o usodi ozemelj in narodov Srednje in Vzhodne Evrope. To pa je območje ki ga je Ramsfeld pred desetletjem poimenoval nova Evropa, za Friedmana je to mejno ozemlje (borderlands), za Mackinderja pa zahodni del strateškega osrčja.

To mejno ozemlje je dobilo pomembno razsežnost po prvi svetovni vojni. Po boljševistični revoluciji v Rusiji leta 1917 in kapitulaciji Nemčije novembra 1918

\footnotetext{
${ }^{13}$ Po ocenah Inštituta za strateške študije iz Londona je Rusija od leta 2008 do 2013 povečala obrambni proračun za $31 \%$.

${ }^{14}$ Nova obrambna strategija ZDA, sprejeta januarja 2012, predvideva prednostno strateško pozornost vzhodni Aziji in Pacifiku.
} 
je Poljska ponovno (po 1795) postala neodvisna država ${ }^{15}$. Friedman poudarja, da je njen prvi voditelj in vojskovodja general Pilsudski poskušal obuditi zamisel nekdanje poljsko-litovske države (Država obeh narodov), ki je nastala sredi 16. stoletja. Obsegala je območje med dvema morjema, Baltskim in Črnim, in je bila nekakšen zid med vzhodom in zahodom, kar je bilo pojmovano kot koncept medmorja ali po latinsko intermarum. Cilj je bil preprečiti vdor sovjetske Rusije v Evropo ter onemogočiti njen stik z Nemčijo (povzeto po: Friedmann, 2014). To se mu ni posrečilo, saj so se preostale države bale izgube nedvisnosti (npr. Litva in takratna Ukrajina), po drugi strani pa je Rdeča armada zasedla Belorusijo in Ukrajino ter ju vključila v novo sovjetsko državo (od 1922 Sovjetska zveza). Poljska se je rešila z vojaško zmago pred Varšavo leta 1920, s čimer se je marca 1921 uradno končala sovjetsko-poljska vojna, začeta februarja 1919.

Posebno poglavje sovjetsko-poljske vojne je bila Ukrajina, ki je bila v načrtih Pilsudskega mišljena kot bistveni element medmorja (Friedman, 2014). Po drugi strani je bil Leninov cilj zasesti vsa ozemlja, ki jih je propadla carska Rusija izgubila z mirom, podpisanim v Brest-Litovsku ${ }^{16}$, vključno s Poljsko. To bi dalo boljševikom dobro izhodiščno točko za svetovno revolucijo, ki je imela široko podporo $\mathrm{v}$ povojnem revolucionarnem vrenju v Nemčiji, Avstriji in na Madžarskem.

Od konca prve svetovne vojne je bilo območje srednje Evrope med Baltikom in Črnim morjem, kot to poimenuje avtor, »lakmusov papir« geostrateških sprememb v Evropi. Od Pilsudskega, nemške okupacije Češkoslovaške leta 1938, napada na Poljsko leta 1939 ter obdobja sovjetske okupacije med hladno vojno pa vse do zloma komunizma, ki se je začel s Solidarnostjo na Poljskem in končal z vključitvijo teh držav $\mathrm{v}$ Evropsko unijo in Nato pred dobrim desetletjem, je to območje sovjetom predstavljalo morebitno bojno polje ter strateško globino. Vseh zadnjih sto let so bile države pod vplivom geostrateških iger velikih igralcev, med katere so bile umeščene. Friedmann je prepričan, da bi bila ponovna obuditev projekta intermarum, ki bi vključeval Poljsko, Slovaško, Madžarsko, Romunijo in pogojno tudi Bolgarijo, ključen geostrateški dejavnik v Evropi, ki bi preprečil ruski vpliv, blokiral stik Nemčije in Rusije ter omejil turški vpliv, ki se po sto letih ponovno krepi v Jugovzhodni Evropi (povzeto po: Friedmann, 2014). Fridmanovo razmišljanje je v delu, ki obravnava Nemčijo in Rusijo, podobno Mackinderjevim zamislim o ureditvi Vzhodne Evrope iz leta 1919 (povzeto po: Mackinder, 1919 in Friedman, 2014).

\subsection{Odnosi med Natom in Rusijo}

V prvem desetletju 21. stoletja se je zdelo, da sta Zahod in Rusija našla skupni jezik o političnem in poslovnem sodelovanju, kar je zagotavljalo stabilnost v Evropi. Še posebno po 11. septembru 2001, ko sta obe državi prepoznali skupno nevarnost $\mathrm{v}$ islamskem terorizmu, in sicer ZDA v Al-Kaidi in z njo povezanih skrajnih islamskih

\footnotetext{
${ }_{15}$ Nemčija se je v začetku prve svetovne vojne in po prodoru centralnih sil v Rusijo odločila oblikovati več držav, med njimi tudi Poljsko, ki bi bile tesno vezane na Nemčijo in bi služile kot vmesno ozemlje med Nemčijo in Rusijo. Ta projekt so imenovali Mittelevropa.

${ }^{16}$ Podpisana marca 1918.
} 
skupinah, Rusi pa v teroristični nevarnosti, ki je izhajala iz posledic dveh vojn $\mathrm{v}$ Čečeniji. Putin in njegov naslednik na predsedniškem položaju Dimitrij Medvedjev sta državo v tem obdobju politično notranje konsolidirala, in to predvsem na račun ugodnih cen pri izvozu nafte in plina, kar je nekajkrat povečalo njen bruto družbeni proizvod $^{17}$. Sodelovanje z Natom se je po letu 1997, ko je bil podpisan Ustanovitveni akt med Natom in Rusijo, poglobilo in od leta 2002 preraslo v strateško partnerstvo (Nato, 2002). Bistveni pomen tega partnerstva je v vzpostavitvi skupne osnove $\mathrm{v}$ obliki Sveta Nato-Rusija, znotraj katere se Nato in Rusija pogovarjata na enakopravni ravni in poglabljata medsebojne odnose ter gradita zaupanje (Nato, 2002).

Na vrhu Nata v Bukarešti aprila 2008 so vodje držav in vlad članic Nata sklenili, da bosta tudi Ukrajina in Gruzija postali članici Nata ${ }^{18}$ (Nato, 2008). Določnost tega dela besedila deklaracije je bilo svojevrstno presenečenje, saj je bilo precedens tako V načinu pošiljanja sporočil mednarodni skupnosti, vključno z Rusijo, kot tudi v diplomatski praksi, ki ji je obljubljanje nekega dejanja vnaprej tuje. Avtor meni, da je bil to po vstopu držav Srednje in Vzhodne Evrope (predvsem Baltskih držav) v Nato eden ključnih trenutkov, ki je v Rusiji obudil tradicionalno nezaupanje do Zahoda (v glavnem ZDA) in Nata kot njegove vojaške platforme.

Odgovor je prišel kmalu. Vrhu Nata v Bukarešti sta še istega leta sledili vojna v Gruziji in začasna zamrznitev Sveta Nato-Rusija. Februarja 2010 je Rusija objavila svojo novo vojaško doktrino, v kateri sta bila nadaljnja širitev Nata na ruske meje in nameščanje njegove vojaške infrastrukture v novih članicah v bližini ruskih meja med drugimi ${ }^{19}$ grožnjami opredeljena kot primarna zunanja grožnja nacionalni varnosti (The Military Doctrine, 2010).

Po začetku krize v Ukrajini so ZDA jeseni 2014 obvestile Severnoatlantski svet o tem, da Rusija krši obveznosti iz pogodbe o jedrskih silah srednjega dometa (INF) ${ }^{20}$, ki zavezuje ZDA in Rusijo, da nimata, ne proizvajata in ne testirata raket dometa med 500 in $5500 \mathrm{~km}$ oziroma nimata in ne proizvajata lansirnih ramp za takšne rakete (Nato, 2014). Cilj te pogodbe je bil zmanjšati grožnje varnosti in stabilnosti v Evropi, še posebno grožnje hitrega napada na tarče, ki imajo strateško vrednost (The INF Treaty, 1987 in Nato, 2014). Ta pogodba je eden izmed temeljev evroatlantske varnosti in stabilnosti. ZDA so vztrajale, da imajo dokaze o tem, da Rusija teh zahtev ne izpolnjuje, zato so jo začele pozivati, da začne izpolnjevati obveznosti iz te pogodbe, saj sicer ruši strateško ravnotežje v Evropi (Nato, 2014).

\footnotetext{
${ }^{17}$ V 90. letih je Rusija gospodarsko stagnirala. Leta 1998 jo je prizadela globoka gospodarska kriza. Po statističnih podatkih, s katerimi razpolaga Trading Economics, je BDP Rusije leta 1990 znašal 516 milijard USD, leta 2000, ko je dosegel dno, pa le še 196 milijard. Deset let pozneje se je dvignil na 1222 milijard, leta 2014 pa je znašal 2096 milijard.

${ }^{18}$ Ta sklep je bil objavljen v uradni deklaraciji na vrhu Nata v Bukarešti 3. aprila 2008.

${ }_{19}$ Druge grožnje vključujejo še ogrožanje strateške stabilnosti, nameščanje tujih vojaških enot v sosednjih drzavah, razvoj balistične raketne obrambe, ki ruši strateško ravnovesje, itn.

${ }^{20}$ INF - Intermediate-Range Nuclear Forces Treaty; pogodba med ZDA in takratno Sovjetsko zvezo je začela veljati leta 1988. Po razpadu Sovjetske zveze je Rusija postala njena pravna naslednica in je prevzela tudi vse mednarodnopravne obveznosti.
} 
To pa ni bilo prvič po hladni vojni, da Rusija ni izpolnjevala pogodbenih obveznosti, ki zagotavljajo strateški mir v Evropi. Leta 2007 je namreč izstopila iz Pogodbe o konvencionalnih silah v Evropi ${ }^{21}$ (OSCE, 2007) in s tem nakazala, da ni zadovoljna $\mathrm{z}$ mednarodno varnostno ureditvijo.

\subsection{Ukrajinska kriza 2014}

Krizo v Ukrajini leta 2014 je treba gledati v okviru širše geostrateške igre, ki se je začela nakazovati že leta 2004 z zmago prozahodnega kandidata za predsednika Ukrajine Viktorja Juščenka. Do leta 2010 je bila v Ukrajini na oblasti prozahodna smer s predsednico vlade Julijo Timošenko. Politično se je njena vlada naslonila na EU in z njo podpisala trgovinski sporazum. Z izvolitvijo Viktorja Janukoviča za predsednika države leta 2010 pa se je to spremenilo (povzeto po: The Economist, 2015). Ukrajinski parlament je junija 2010 izglasoval poseben zakon, s katerim se je Ukrajina zavezala, da ostaja zunaj kakršnega koli vojaškega zavezništva, dopuščal pa je stike z vojaškimi zavezništvi, kot je Nato.

Tako imenovana majdanska revolucija, ki se je končala z odstavitvijo predsednika Janukoviča in izvolitvijo nove vlade konec februarja 2014, je povzročila zavrnitev podpisa pridružitvenega sporazuma z EU novembra 2013. Rusija se je na imenovanje nove prozahodne vlade $\mathrm{v}$ Kijevu odzvala $\mathrm{z}$ intervencijo na polotoku Krim, ki si ga je marca 2014 po hitrem referendumu pripojila, na vzhodu Ukrajine (Doneck in Lugansk) pa je prišlo do upora rusko govorečega prebivalstva, vključno z razglasitvijo neodvisnosti teh dveh regij. To je sprožilo oborožen konflikt $\mathrm{z}$ vlado $\mathrm{v}$ Kijevu (povzeto po: The Economist, 2015).

Ukrajina je od razglasitve samostojnosti decembra 1991 lovila ravnotežje med Rusijo in Zahodom, a je bila do leta 2014 bolj ali manj v ruskem območju vpliva. Z odločitvijo, da se približa Zahodu, je praktično ogrozila ruske načrte o vzpostavitvi Evrazijske unije ${ }^{22}$, ki jo je Rusija načrtovala po vzoru EU (kot njeno protiutež), njena osrednja država bi bila Rusija, Ukrajina, na ozemlju katere je nekoč obstajala kijevska srednjeveška država, ki jo Rusi pojmujejo kot zibelko ruske državnosti, pa njen sestavni del. Kot trdi Neyfakh, si moderna ruska politična elita (pod Putinom in Medvedjevom) s projektom Evrazijske unije in njene vojaške različice (Organizacija Pogodbe o kolektivni varnosti) ${ }^{23}$ prizadeva povrniti geostrateški vpliv, ki ga je izgubila z razpadom Sovjetske zveze (povzeto po: Neyfakh, 2014).

\footnotetext{
${ }^{21}$ The Treaty on Conventional Armed Forces in Europe (The CFE Treaty). Pogodba iz leta 1990 je ena najpomembnejših pogodb o nadzoru oborožitve med hladno vojno. Členi pogodbe natančno določajo najvišje dovoljeno število kosov konvencionalnega orožja, ki je lahko med Atlantikom in Uralom. Pogodba je bila leta 1999 dopolnjena, predvsem z vidika konca hladne vojne in razpustitve Varšavskega pakta.

${ }^{22}$ Pogodba o ustanovitvi Evrazijske unije je začela veljati 1. januarja 2015. Namen te unije je gospodarsko in politično povezovanje držav, ki so nastale po razpustitvi Sovjetske zveze leta 1991. Po ruskih načrtih bi morala biti Ukrajina, poleg Belorusije in Kazahstana, četrta sopodpisnica ustanovitvene pogodbe.

${ }^{23}$ Organizacija je nastala leta 1992 iz držav naslednic Sovjetske zveze. Članice so Rusija, Kazahstan, Tadžikistan, Kirgizistan, Belorusija in Armenija.
} 
Ni povsem jasno, kakšen je dolgoročni cilj priključitve Krima in kakšno ceno bo za ta korak plačala Rusija. Je pa z geostrateškega vidika polotok Krim pomemben

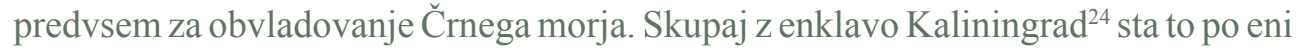
strani dva branika Rusije globoko v Evropi, po drugi pa dve točki, od koder je mogoče usmeriti silo proti Evropi in Natu. Kot navaja Adamowski, je Nato v najnovejši ruski vojaški doktrini ${ }^{25}$, ki je bila objavljena konec decembra 2014, opredeljen kot eden glavnih dejavnikov ogrožanja Rusije (povzeto po: Adamowski, 2015).

\subsection{Severna Afrika in Bližnji vzhod}

Varnost Evrope je bila od nekdaj odvisna tudi od njene neposredne južne in jugovzhodne soseščine. Od 19. stoletja naprej sta predvsem Francija in Velika Britanija obvladovali Severno Afriko, s propadom Otomanskega cesarstva po prvi svetovni vojni pa tudi Bližnji vzhod, ki sta si ga razdelili skladno s Sporazumom Sykes-Picot iz leta 1916 (The Sykes-Picot Agreement, 1916). V to obdobje segajo tudi vprašanje Palestine in ustanovitev Izraela ter razdelitev nadzora nad ozemljem Iraka in Sirije. Slednje sto let pozneje povzroči grožnje Evropi zaradi razglasitve Islamskega kalifata v Iraku in Siriji - ISIL ${ }^{26}$. Dejstvo je, da se je v zadnjih nekaj letih varnostna situacija poslabšala, predvsem pa po arabski pomladi, ki se je začela decembra 2010 v Tunisu, nadaljevala v Egiptu ter privedla do intervencije Nata v Libiji leta 2011 (Nato, 2014). Celotno območje je, predvsem zaradi nedelovanja državnih struktur, postalo varnostno izrazito nestabilno in dolgoročno nevarno za Evropo.

Sklep V minulih sto letih se je Evropa zelo spremenila. Dvajseto stoletje, ki se je politično gledano začelo s prvo svetovno vojno in končalo s terorističnimi napadi 11. septembra 2001 v ZDA, je popolnoma spremenilo geopolitični zemljevid Evrope in sveta. Tako druga svetovna vojna kot tudi hladna vojna sta obe logični posledici prve svetovne vojne, prav tako Društvo narodov, ki ga je Wilson videl kot temelj novega svetovnega reda, in katerega pravni naslednik je Organizacija združenih narodov.

Varnostno-politični izzivi, s katerimi se danes srečujemo, večinoma izvirajo iz odločitev in dogodkov, ki so se zgodili zaradi prve svetovne vojne oziroma njenih posledic. Do konca hladne vojne je bila večina teh konfliktov zamrznjena oziroma jih je nadzorovala ena ali druga velesila. Po koncu hladne vojne pa je prišel čas preurejanja, predvsem v Evropi je prišlo s padcem Berlinskega zidu do največjih geostrateških sprememb, med njimi do združitve Nemčij ter razpada Sovjetske zveze, Jugoslavije in Češkoslovaške. Ti dogodki so v dveh desetletjih povzročili popolnoma drugačno geostrateško sliko v Srednji in Vzhodni Evropi.

\footnotetext{
${ }^{24}$ Kaliningrad je ruska enklava ob Baltskem morju, kjer je sedež ruske baltske flote.

${ }_{25}$ V novi doktrini, ki jo je ruski predsednik Putin podpisal 26. decembra 2014, najdemo odgovor Rusije na sklepe Nata, sprejete na vrhu v Walesu septembra 2014. Šrjenje Natove infrastrukture k ruskim mejam je ena največjih groženj. Kot odgovor na to nova doktrina predvideva tesnejše sodelovanje z državami BRICS (Brazilija, Indija, Kitajska in Južna Afrika). Nova doktrina predvideva tudi povečanje ruske vojaške prisotnosti na območju Arktike in razvoj raketne obrambe, skupaj z ruskimi zaveznicami.

${ }^{26}$ Islamska država v Iraku in Levantu (angl. Islamic State in Iraq and Levant - ISIL).
} 
Današnja združena Nemčija, ki je tudi naslednica nekdanje zahodne Nemčije, je drugačna od tiste izpred leta 1989. Je bolj samozavestna, gospodarsko uspešna, vendar vojaško in geostrateško ostaja previdna in sistematična. Današnja Nemčija je z združitvijo podedovala geostrateške elemente obeh Nemčij, vključno z bremeni prve in druge svetovne vojne. Ob upoštevanju teh dejavnikov je lažje razumeti današnjo nemško strateško postavljanje v središče Evrope, kot most med nekdanjo Zahodno in Vzhodno Evropo, ki vključuje Rusijo in Rumsfeldovo novo Evropo, kar po Mackinderju sovpada z zahodnim delom strateškega osrčja. Izkušnje dveh vojn in obdobja do leta 1990 se logično kažejo v nemški zunanji in obrambni politiki (povzeto po: Kurbjuweit, 2014). Po eni strani (predvsem od napada ZDA na Irak leta 2003) deluje bolj suvereno, po drugi pa si prizadeva za zbližanje gospodarskih in političnih odnosov z Rusijo, na podlagi izkušenj iz obeh svetovnih vojn pa svari pred eskalacijo konfliktov.

Evropskimir, utemeljen naizkušnjah prvein druge svetovnevojne terinstitucionaliziran z Evropsko unijo, temelji predvsem na miru in prijateljstvu med Francijo in Nemčijo. Seveda pa je pri tem treba upoštevati predpostavko, da državi sprejemata ta odnos na enakopravnih temeljih, pri čemer se lahko ta občutek spremeni (povzeto po: Smale, Alderman, 2014), če pride do gospodarske prevlade ene države. Desetletja po drugi svetovni vojni ta mir ni bil ogrožen. Trenutne razmere kažejo na šibkejšo gospodarsko moč Francije in prevladujoč položaj Nemčije, ki se kaže v povečanem političnem vplivu. To je posebno opazno v vzhodnem delu Evropske unije oziroma tako imenovani novi Evropi, v kateri ima Nemčija močan politični vpliv.

Zgodovinsko je takšna pozicija lahko varnostno vprašljiva, saj lahko zrahlja odnose s Francijo in tudi z Veliko Britanijo, ki je na kontinentu tradicionalno poskušala preprečevati prevlado katere koli evropske sile. S podpisom Strateškega sporazuma leta 2010 so se težnje približevanja Francije in Velike Britanije začele jasneje nakazovati. Rahljanje ustaljenega ravnotežja v Evropi, katerega povod (in ne razlog) je finančna kriza leta 2008, se v Veliki Britaniji kaže tudi v zavezi britanskega premierja Camerona, da leta 2017 razpiše referendum o prihodnosti Velike Britanije v Evropski uniji, kar je lahko nevaren precedens za prihodnost Evropske unije.

$\mathrm{Na}$ drugi strani je Rusija, ki hote ali nehote spominja na poversajsko Nemčijo. Zanimivo je, da vladajoče ruske politične elite vidijo Rusijo kot naslednico Sovjetske zveze ne le v pravnem, temveč tudi v političnem in teritorialnem smislu. Neodvisne države, ki so nastale na ozemlju nekdanje Sovjetske zveze, vidijo kot izgubljeno ozemlje (podobno kot je to počela weimarska Nemčija, ki je ozemlje izgubila po letu 1918). Podobnosti v politični anarhiji devetdesetih let v Rusiji in dvajsetih v Nemčiji, v gospodarski krizi v Rusiji leta 1998 ter v Nemčiji takoj po vojni ter predvsem v občutku ponižanja zaradi kapitulacije v prvi svetovni vojni oziroma izgube v hladni vojni se ponujajo same od sebe. $Z$ dogodki, ki smo jim bili priča leta 2014, ter ob dejstvu, da se je Rusija umaknila iz Pogodbe o konvencionalnih silah ter da prav tako ne izpolnjuje obveznosti iz Pogodbe o jedrskih silah srednjega dometa, pomeni, da se geostrateško odmika od preostale Evrope. 
Zanimiva je drža ZDA, ki so januarja 2012 z razglasitvijo novih strateških usmeritev svojo vojaškopolitično pozornost namenile vzhodni Aziji in Pacifiku. S tem so prvič po prvi svetovni vojni svojo primarno strateško pozornost uradno prenesle iz Evrope.

Kitajska, ki je v tem članku nismo podrobneje omenjali, ostaja neznanka. Kljub temu je jasno, da Peking postaja vedno pomembnejši sogovornik Washingtona o globalnih zadevah. Značilen je primer ukrajinske krize, v kateri je bila od stalnih članic Varnostnega sveta Združenih narodov Kitajska edina, ki ni bila neposredno vpletena, kar ji daje manevrski prostor, da, kot pravi avtor, »stopi v čevlje, ki jih je nekdaj nosila Sovjetska zveza«. Kitajska je po začetku ukrajinske krize z Rusijo podpisala sporazum o gradnji plinovoda, s čimer jo je v perspektivi tesneje vezala nase, Rusiji pa omogočila alternativno tržišče ${ }^{27}$. Kot protiutež sankcijam, ki jih je uvedla Evropska unija, ji je, kot piše Rettman, ob koncu leta 2014 ponudila tudi denarno pomoč (Rettman, 2014). Nastaja vtis in o tem piše tudi Zanitti, da se s približevanjem Kitajske in Rusije (ter pogojno tudi Indije) nakazujejo poskusi vzpostavitve novega, večpolarnega sveta (povzeto po: Zanitti, 2015). Ta korak lahko razumemo tudi kot logičen odgovor Pekinga (in Moskve) na preusmeritev ZDA v vzhodno Azijo in na Pacifik.

Kot vidimo pri samooklicani Islamski državi v Levantu(ISIL), pa prazen prostor, ki nastane za propadlimi državami, odpira vrata novim igralcem. Trenutno je težko napovedati, kakšna je prihodnost Bližnjega vzhoda, dejstvo pa je, da dejavniki, kot je ISIL, skupaj s terorističnimi organizacijami, ki so povezane z Al-Kaido, rušijo sedanji red na Bližnjem vzhodu. Dodatno skrb povzročajo tudi njihove aktivnosti v Evropi, kar ima neposreden vpliv na notranjo politiko evropskih držav ${ }^{28}$ in njihovo razumevanje varnosti.

V teh letih, ko se svet spominja stote obletnice začetka prve svetovne vojne, je položaj v Evropi in svetu vse prej kot preprost. Kriza v Ukrajini je svet privedla do največjih napetosti med Rusijo in ZDA (s članicami Nata) po koncu hladne vojne. Ta kriza je razgalila vso krhkost sedanjega svetovnega reda. Trenutno je najšibkejša točka Evrope Rumsfeldova nova Evropa kot del Mackinderjevega osrčja, ki je bila ob vseh velikih svetovnih spremembah predmet geostrateških preigravanj in, kot temu pravi avtor, »lakmusov papir« prihodnjih dogodkov.

V tem trenutku je težko reči, ali smo pred tako velikimi spremembami, da bo v svetu nastal nov red, pojavljajo pa se težnje, ki spominjajo na tiste izpred prve svetovne vojne, predvsem podobnosti v vedenju držav in neformalnem obujanju tradicionalnih zavezništev. Občutiti in opaziti je mogoče veliko dejavnikov, ki so bili našteti v tem članku, ki nakazujejo, da bo obdobje, ki prihaja, drugačno od tistega, ki smo ga živeli do zdaj. Čas bo pokazal, ali smo pridobljene izkušnje iz zadnjih sto let uporabili tako, da smo se v prelomnih trenutkih sposobni izogniti napakam, ki so bile narejene $\mathrm{v}$ stoletju, ki je za nami.

\footnotetext{
${ }^{27}$ Po podatkih Thomas White International je industrija, povezana z nafto in plinom, leta 2010 predstavljala $30 \%$ ruskega BDP in $60 \%$ vsega ruskega izvoza.

${ }_{28}$ Teroristični napadi po Evropi prispevajo $k$ vzponu antiislamističnih strank, kar radikalizira notranjepolitične razmere v evropskih državah.
} 


\section{Literatura}

1. Adamowski, J., 2015. Russia Overhauls Military Doctrine. Defence News International, Vol. 3 No. 1, Gannett Government Media, Springfield, VA, 2015.

2. Baker, M., 2003. U. S.: Rumsfeld's 'Old'And 'New'Europe Touches On Uneasy Divide, Radio Free Europe, http://www.rferl.org/content/article/1102012.html, 15. januar 2015.

3. BBC News, 2007. Russia suspends arms control pact. BBC, http://news.bbc.co.uk/2/hi/ europe/6898690.stm, 15. januar 2015.

4. Encyclopedia Britannica, 2014. European History, Franco-German War, http://www. britannica.com/EBchecked/topic/216971/Franco-German-War, 12. januar 2015.

5. Encyclopedia Britannica, 2013. Sir Halford John Mackinder. http://www.britannica.com/ EBchecked/topic/354948/Sir-Halford-John-Mackinder, 14. januar 2015.

6. European Union, 2014. EU treaties, http://europa.eu/eu-law/decision-making/treaties/ index en.htm, 20. december 2014.

7. Ferguson, S. T., 2014. Game Theory, Mathematics department, UCLA, http://www.math. ucla.edu/ tom/Game_Theory/mat.pdf, 10. januar 2015.

8. Friedman, G., 2014. Geopolitical Journey, Part 2: Borderlands, Stratfor, http://www.stratfor.com/weekly/20101108_geopolitical_journey_part_2_ borderlands\#axzz3PqhmmCx3, 3. junij 2014.

9. Friedman, G., 2014. The Top Five Events in 2014, Stratfor, http://www.stratfor.com/ weekly/top-five-events-2014\#axzz3OssDl2Ds, 7. januar 2015.

10. Gherghisan, M., 2003. Vilnius 10 sign letter on Iraq, EU Observer, https://euobserver. com/enlargement/9269, 16. december 2014.

11. Kurbjuweit, D., 2014. The Merkel Effect: What Today's Germany Owes to Its OnceCommunist East, Spiegel Online International, http://www.spiegel.de/international/ germany/how-east-germany-influences-modern-day-german-politics-a-994410.html, 8 . oktober 2014.

12. Mackinder, H. J., 1919. Democratic Ideals and Reality: A Study in the Politics of Reconstruction, National Defence University, Institute for National Strategic Studies, National University Press Publications, Washington D.C.,1942.

13. Mackinder, H. J., 1904. The Geographical Pivot of History. The geographical Journal, Vol. 23, No. 4, 421-431, The Royal Geographical Society, London, 2004.

14. MacMillen, M., 2003. Paris 1919, Six months that changed the world. The Random House Publishing Group, New York, 2003.

15. National Centre for Strategic Studies, 2014. America needs a Poland that is more self sufficient, Stratfor, http://www.stratfor.com/the-hub/america-needs-poland-more-selfsufficient\#axzz3679aDxI5, 1. julij 2014.

16. Neyfakh, L., 2014. Putin's long game? Meet the Eurasian Union, The Boston Globe, http://www.bostonglobe.com/ideas/2014/03/09/putin-long-game-meet-eurasianunion/1eKLXEC3TJfzqK54elX5fL/story.html, 20. december 2014.

17. NATO, 2014. A short history of NATO, http://www.nato.int/history/index.html, 15. december 2014.

18. NATO, 2009. Article 51 of the Charter of the United Nations, NATO, http://www.nato.int/ cps/en/natolive/official_texts_16937.htm, 17. september 2014.

19. NATO, 2014. ISAF, NATO, http://www.isaf.nato.int/, 1. oktober 2014.

20. NATO, 2014. NATO-Russia Council, NATO, http://www.nato.int/cps/ro/natohq/ topics_50091.htm, NATO Russia Council, 29. december 2014.

21. NATO, 2014. Statement by the Secretary General on the INF Treaty, NATO, http://www. nato.int/cps/en/natolive/news_111823.htm, 29. december 2014.

22. NATO, 2008. Bucharest Summit Declaration, NATO, http://www.nato.int/cps/en/natohq/ official_texts_8443.htm?selectedLocale=en, 29.december 2014.

23. NATO, 1949. The North Atlantic Treaty, http://www.nato.int/cps/en/natolive/official_ texts_17120.htm, 20. december 2014. 
24. Nelson, M.R., Belkin, P., Mix, D.E., 2011. Greece's Debt Crisis: Overview, Policy. Responses, and Implications, Congressional Research Service, http://fas.org/sgp/crs/row/ R41167.pdf, 10. oktober 2014.

25. OSCE, 2013. Conference on Security and Co-Operation in Europe Final Act 1975, http:// www.osce.org $/ \mathrm{mc} / 39501$ ? download=true, 30. september 2014.

26. OSCE, 2007. OSCE Chairman expresses hope for renewed CFE negotiations, http://www. osce.org/cio/49292, 6. december 2014.

27. Rettman, A., 2014. China ignores EU, offers to help Russia, EU Observer, https:// euobserver.com/foreign/127036. 14, in 15. januar 2015.

28. Simms, B., 2013. Europe: The Struggle for Supremacy, from 1453 to the Present, Basic Books, New York, 2013.

29. Smale, A., and Alderman, L., 2014. Growing Imbalance between Germany and France strains their relationship, The International New York Times, http://www.nytimes. com/2014/09/22/world/europe/imbalance-between-germany-and-france-strainsrelationship.html? $r=0$, 13. januar 2015.

30. The Charter of the United Nations, 1945, http://avalon.law.yale.edu/20th_century/ unchart.asp, 1. januar 2015

31. The Covenant of the League of Nations, 1919. http://avalon.law.yale.edu/imt/parti.asp, 1. januar 2015.

32. The Economist, 2013. The origins of the financial crisis, Crash course, The Economist, http://www.economist.com/news/schoolsbrief/21584534-effects-financial-crisis-are-stillbeing-felt-five-years-article, 9. oktober 2014.

33. The Economist, 2013. The road to 2017. What the reshuffle says about David Cameron's plans for Europe, http://www.economist.com/news/britain/21607833-what-reshuffle-saysabout-david-camerons-plans-europe-road-2017, 17. december 2014.

34. The Economist, 2014. Europe's elections. The Eurosceptic Union. The impact of the rise of anti-establishment parties, in Europe and abroad, The Economist, http://www. economist.com/news/europe/21603034-impact-rise-anti-establishment-parties-europeand-abroad-eurosceptic-union, 14 januar 2015.

35. The Economist, 2015. From cold war to hot war, Russia's aggression in Ukraine is part of a broader, and more dangerous, confrontation with the West, http://www.economist.com/ news/briefing/21643220-russias-aggression-ukraine-part-broader-and-more-dangerousconfrontation, 14. februar 2015.

36. The Guardian, 2003. France and Germany unite against Iraq war, The Guardian, http:// www.theguardian.com/world/2003/jan/22/germany.france, 01. oktober 2014.

37. The Military Doctrine of the Russian Federation, 2010. http://www.sras.org/military_ doctrine_russian_federation_2010,29. december 2014.

38. The Monroe doctrine, 1823. http://web.archive.org/web/20120108131055/http:/eca.state. gov/education/engteaching/pubs/AmLnC/br50.htm, 10. januar 2015.

39. The Sykes-Picot Agreement, From WW I Document Archive, 1916. http://www.saylor.org/ site/wp-content/uploads/2011/08/HIST351-9.2.4-Sykes-Picot-Agreement.pdf, 12. januar 2015.

40. The Three-Power Pact between Germany, Italy, and Japan, 1940. http://avalon.law.yale. edu/wwii/triparti.asp, 1. januar 2015.

41. The Treaty on Elimination of Intermediate-Range and Shorter-Range Missiles- between USA and USSR (The INF Treaty text 1987), http://cns.miis.edu/inventory/pdfs/aptinf.pdf, 29. december 2014.

42. The Japan Times, 2014. Russian military regain its clout, http://www.japantimes.co.jp/ news/2014/02/28/world/russian-military-regains-its-clout/\#.VMPUakfF_ht, 1. januar 2015 . 
43. Thomas White International, 2011. Oil \& Natural Gas Sector in Russia: Fueling Growth, http://www.thomaswhite.com/global-perspectives/oil-natural-gas-sector-in-russia-fuelinggrowth/, 10. januar 2015.

44. Trading Economics, 2015. Russia GDP 1989 - 2015, http://www.tradingeconomics.com/ russia/gdp, 2. januar 2015.

45. UK, 2010. The Treaty between the United Kingdom of Great Britain and Northern Ireland and the French Republic for Defence and Security Co-operation, https://www.gov.uk/ government/uploads/system/uploads/attachment_data/file/238153/8174.pdf, 14. januar 2015.

46. UN, 2014. Structure and organization of the United Nations, UN, http://www.un.org/en/ aboutun/structure/\#Others, 17. september 2014.

47. UN, 2002. United Nations Security Council Resolution 1441 (2002), http://www.un.org/ depts/unmovic/documents/1441.pdf, 1. oktober 2014.

48. U.S. Department of Defence, 2012. Sustaining US Global Leadership: Priorities for 21st Century Defence, US Department of Defence, http://www.defense.gov/news/defense strategic_guidance.pdf, 3. julij 2014.

49. U.S. Department of State, 2014. Adherence to and Compliance with Arms Control, Nonproliferation, and Disarmament Agreements and Commitments, http://www.state.gov/ documents/organization/230108.pdf, 30. september 2014.

50. Wilson, W., 2015. The Biography.com website, http://www.biography.com/people/ woodrow-wilson-9534272, 14. januar 2015.

51. Zanitti, B. F., 2015. Russia, China and India building new multipolar world order, http:// english.pravda.ru/world/asia/15-01-2015/129526-russia_china_india-0/, 15. januar 2015. 


\section{KEMIČNO OROŽJE - POSEBNOST PRVE SVETOVNE VOJNE ALI ŠE DANES PRETEČA NEVARNOST}

\section{CHEMICAL WEAPONS - PARTICULARITY OF WORLD WAR I OR A STILL IMMINENT DANGER}

Povzetek Kemično orožje je svoj največji razmah doživelo med prvo svetovno vojno, ko so ga uporabljale sile obeh v vojno vpletenih strani, čeprav je bila s haaškimi deklaracijami uporaba strupov v bojne namene prepovedana že pred vojno. Med prvo svetovno vojno je bilo razvitih in uporabljenih več vrst kemičnega orožja, pri čemer so največjo uporabnost ter uničevalno moč pokazali klor, fosgen in iperit. Odziv na uporabo smrtonosnega tihega orožja je bil razvoj zaščitnih mask, pri čemer pa mnoge niso zadoščale standardom in so se $\mathrm{v}$ kriznih trenutkih pokazale kot neučinkovite. Uporaba kemičnega orožja je v prvi svetovni vojni povzročila veliko žrtev, vendar ni odločilno vplivala na končni izid vojne. Zaradi izjemne smrtonosnosti in uničujočih fizioloških ter psiholoških posledic, ki jih je povzročilo kemično orožje v času tako imenovane Velike vojne, so si mednarodne sile po letu 1918 prizadevale zagotoviti, da se ta tihi ubijalec ne bi več uporabljal v bojne namene. To je bil tudi eden izmed vzrokov, zakaj ni prišlo do večjega razmaha uporabe kemičnega orožja po tem letu. Prizadevanja mednarodne skupnosti po izkoreninjenju bojnih strupov pa niso preprečila razvoja znanosti, ki je v 20. stoletju prinesel odkritja novih strupenih orožij, ki jih v prvi svetovni vojni še niso poznali.

\section{Ključne Kemično vojskovanje, orožje za množično uničevanje, zaščita pred kemičnim} besede vojskovanjem, prva svetovna vojna, kemični terorizem.

Abstract Chemical weapons saw their largest growth during World War I, when it was used by the forces of both involved parties despite the fact that the use of casualty agents had been banned by Hague declarations even before the war. Several types of chemical weapons were used and developed during World War I with chloride, phosgene and mustard gas proving to be most useful and destructive. As a response to the use of this lethal silent weapon protection masks were developed. However, many of them did not meet the standards and proved to be ineffective during crisis. 
The use of chemical weapons in World War I caused numerous casualties, but did not decisively impact the final outcome of the war. Due to the extremely lethal nature and devastating physiological and psychological consequences caused by chemical weapons during the Great War, international forces after 1918 made every effort to never use this silent murderer in combat again. This was also one of the reasons why chemical weapons did not see too large of a development after this period. However, international efforts to root out casualty agents did not prevent the scientific development, which in the $20^{\text {th }}$ century brought the discovery of new toxic weapons which had not been known during World War I.

\section{Key words Chemical warfare, weapons of mass destruction, protection against chemical} warfare, World War I, chemical terrorism.

Uvod Leta 1914 je Evropo zajela težko pričakovana vojna. Želja po vojni v Evropi je bila velika, saj človeštvo do tedaj še ni izkusilo spopada svetovnega obsega. Obe sprti strani, centralne sile in antanta, sta verjeli v svoje vojaške zmožnosti in bili prepričani, da bosta v vojni zmagali. Kmalu pa se je izkazalo, da vojna ne bo izpolnila pričakovanj vpletenih. Namesto da bi se končala v nekaj mesecih, se je morija zavlekla v nekaj let. Postala je vojna izčrpavanja. Vojna je potekala na stabiliziranih frontah strateškega obsega, ki brez močne industrije v zaledju ne bi obstale. V ospredje je prišlo preizkušanje industrijske moči vpletenih strani. Pomembno vlogo v vojni agoniji je imelo artilerijsko orožje, ki je med drugim tudi precej prispevalo k temu, da se je vojna spremenila v pozicijsko. Nobeno izmed konvencionalnih orožij ni bilo sposobno prebiti fronte in doseči večjega premika, zato so bile vojaške oblasti dovzetne za kakršne koli bojne izume, ki bi prinesli spremembo. Napredek kemične znanosti v 19. in začetku 20. stoletja sta s pridom izkoristili obe vojskujoči se strani.

\section{METODE}

Vodilo prispevka je predstaviti obseg uporabe kemičnega orožja v prvi svetovni vojni in uporabo po koncu Velike vojne. V drugem delu nas je zanimalo, koliko kemično orožje še danes pomeni grožnjo za človeštvo. V pomoč so nam bili predvsem nemški, francoski, britanski in ameriški viri, saj je kemična vojna potekala predvsem na zahodni fronti. Tako so viri in literatura, ki se ukvarja s kemičnimi agensi v prvi svetovni vojni na zahodni fronti, precej obsežni. Obravnav uporabe kemičnih agensov na drugih frontah je manj, kljub temu pa vendarle najdemo informacije o kemičnih napadih na primer na slovenskih tleh. V zvezi s tem nas je zanimalo tudi, kako obsežne so bile posledice uporabe teh strupenih snovi za prihodnje generacije.

$\mathrm{Z}$ metodo primerjalne analize smo raziskali, koliko je bila izkušnja prve svetovne vojne na področju kemičnih napadov poučna za človeštvo. Tako smo se posvetili uporabi kemičnih agensov po prvi svetovni vojni in primerjali množičnost uporabe. 
V ožjem pogledu nas je zanimalo, ali ukrepi mednarodne skupnosti za kemično razoroževanje res pomenijo varnost pred morebitnim neslišnim in nevidnim sovražnikom. Analiza se posveča vzrokom, zaradi katerih so bile prepovedi uporabe kemičnih agensov upoštevane oziroma niso bile upoštevane $\mathrm{v}$ različnih časovnih obdobjih.

\section{RAZVOJ KEMIČNEGA OROŽJA}

Razvoj kemije kot znanosti se je začel šele v 19. stoletju in proizvodnja kemikalij je kmalu pokazala, da je veliko teh snovi v določenih količinah za človekovo zdravje in življenje nevarnih (Broyles, 2005). V napredku kemične znanosti in industrije je prednjačila Nemčija. Po mnenju Andréja Moureuja brez svoje industrije in še posebej brez kemične industrije ne bi napovedala vojne Franciji leta 1914. André Moureu je leta 1920 izdal delo Kemija in vojna (fr. La Chimie et la Guerre), v katerem je analiziral razvoj kemične industrije v Nemčiji pred Veliko vojno in ugotavljal veliko zaostajanje Francije za nemškim napredkom leta 1914 (po Lejaille, 2013, Introduction).

Generalštabi vpletenih držav leta 1914 niso predvidevali dolgotrajne vojne in nanjo tudi niso bili pripravljeni. Ko se je vojna spremenila v pozicijsko in bojevanje $\mathrm{v}$ agonijo, so vsi upali na izum »čudežnega orožja«, ki bi s svojo izjemno uničevalno močjo omogočilo hiter preboj fronte in zmago na bojišču (Lejaille, 2013, Introduction). 14. septembra 1914 je vodenje nemškega generalštaba iz rok ostarelega generala von Moltkeja prevzel general von Falkenhayn, ki je takoj ukazal začetek raziskav za iznajdbo učinkovitega kemičnega orožja (Legg in Parker, 2002).

Vojna je že jeseni 1914 postala pozicijska in med položaji sovražnikov je bilo pogosto le nekaj sto metrov razdalje, zato je imela artilerija težave, saj je pogosto povzročila precej škode tudi lastni pehoti. Poleg tega je artilerija s težavo dosegala rove $\mathrm{v}$ skritih predelih, saj so postajali nasprotnikovi rovi vse bolje utrjeni in vse globlje skopani. Te težave artilerije bi lahko premostilo novo skrivnostno orožje, ki bi se nevidno in tiho širilo v nasprotnikove položaje in onesposobilo moštvo. O tem orožju so razmišljali na obeh straneh, v raziskavah pa so prednjačili Nemci pod vodstvom Fritza Haberja (Legg in Parker, 2002). ${ }^{1}$

\footnotetext{
Fritz Haber je bil znamenit kemik in pozneje Nobelov nagrajenec, ki je vodil nemški raziskovalni program kemičnega vojskovanja. Poimenovali so ga »oče kemične vojne«, Nobelovo nagrado za kemijo je dobil leta 1918 za sintezo amoniaka (Fitzgerald, 2008). Z njim je kemijska znanost postala ne samo nosilka napredka človeštva, temveč tudi uničujoča sila ekstremnih razsežnosti. Njegov moto je bil, da mora znanost v miru služiti človeštvu, v vojni pa domovini (nem. Im Frieden für die Menschheit, im Krieg für das Vaterland). Čeprav je Haber služil domovini, mu je ta pozneje obrnila hrbet in je moral leta 1933 bežati v Anglijo, saj je bil judovskega porekla. Veliko njegovih sorodnikov je končalo svojo življenjsko pot v nemških koncentracijskih taboriščih. Nekateri izmed njih so bili žrtve njegovega lastnega izuma-ciklona B (Hofmann, 2014).
} 


\section{PRVA UPORABA KEMIČNEGA OROŽJA V PRVI SVETOVNI VOJNI}

Čeprav prevladuje mnenje, da so prvi uporabili kemično orožje Nemci na zahodni fronti, pa je dejstvo, da so to orožje leta 1914 prvi uporabili Francozi. Francozi so želeli z uporabo kemičnega orožja doseči, da bi sovražnikove enote pregnali s položajev, ki jih artilerija ni dosegla (Lejaille, 2013, Introduction). Že avgusta 1914 so francoske sile na zahodni fronti uporabljale 26-milimetrske granate, imenovane cartouches suffocantes, polnjene s solzivcem etil bromoacetatom. ${ }^{2} \mathrm{Na}$ bojišču je bil njegov učinek tako zanemarljiv, da nemške sile uporabe kemičnega agensa niso niti zaznale (Hutchinson, 2004, str. 200). Prvi poskusi uporabe kemičnega orožja niso bili obetavni.

Odgovor nasprotnih sil pa je vendarle prišel v samo nekaj mesecih. 27. oktobra 1914 so Nemci izstrelili 3000 artilerijskih izstrelkov s kodnim imenom Ni-Schrapnell, polnjenih z dražljivcem dianisdin klorosulfonatom, na britanske enote $\mathrm{v}$ bližini Neuve-Chapelle, vendar je bil kemični napad brez učinka. Najverjetneje je bilo kemično sredstvo uničeno že z eksplozijo ob stiku z bojiščem. Koncentracija strupenega agensa je bila premajhna, da bi povzročila škodo sovražniku (Wietzker, 2006, str. 30). Na vzhodni fronti pa so nemške sile kemično orožje prvič uporabile 30. januarja 1915 v obliki mešanice ksililbromida, ksililenbromida (s kodnim imenom T-Stoff) in benzilbromida pri Bolimówu na območju današnje Poljske, vendar so nizke temperature preprečile širjenje strupa, zaradi česar ni imel posebnega učinka (Hutchinson, 2004, str. 199).

\section{KLOR IN ZAČETEK KEMIČNE VOJNE}

Leta 1915 so nemški znanstveniki pod vodstvom Fritza Haberja v Inštitutu cesarja Viljema v Berlinu (nem. Kaiser Wilhelm Institut) razvili klor za bojno uporabo. ${ }^{3}$ Klor so vstavili v posebej za to izdelane jeklenke, da bi ga iz njih izpustili na bojišče $\mathrm{v}$ rove nasprotnikovih vojakov. Nemško vrhovno poveljstvo je od tega orožja pričakovalo, da bo pregnalo vojake iz strelskih jarkov, ne pa množičnega smrtonosnega učinka (Fitzgerald, 2008). Klor je težji od zraka, kar je zagotavljalo, da se bo dlje časa zadrževal na bojnih položajih (Cobb, 2000, str. 43). Aprila 1915 so bili Nemci pripravljeni na prvi večji napad s klorom. Francoske sile so prejele obvestila belgijske vojske in poročila nemških zajetih vojakov, da se pripravlja nemški napad s kemičnim orožjem, vendar jih niso jemale resno. Do tedaj se raba kemičnega orožja na bojišču ni izkazala kot učinkovita in ni povzročila resnih posledic. Druga bitka pri Ypresu v Belgiji pa je prinesla veliko presenečenje (Duffy, 2009) in dokazala, da so bojni strupi orožje za množično uničevanje (Brezina, 2005, str. 23). 22. aprila 1915 je nemška vojska ob primernem vetru nad strelske jarke antantnih sil izpustila 180 ton klora iz 5730 jeklenk (A short History of CW

Ta solzivec je francoska policija uporabljala za začasno onesposobitev in ni imel smrtonosnega učinka. Ne glede na to so strokovnjaki menili, da ga je vredno preizkusiti tudi na fronti (Hutchinson, 2004, str. 200).

3 Klor je močan dražljivec - dušljivec, ki poškoduje oči in dihalne poti ter organe. Ob večji koncentraciji in daljšsem času vdihavanja tega agensa pride do smrti. Dušljivce so Nemci poimenovali tudi zeleni križ (Grünkreuz), saj so izstrelke s tem strupom označevali z zelenim križem. 
during WWI., online) (po drugih virih pa 150 ton, gl. npr. Lejaille, 2013; oziroma 168 ton). Na francosko stran je veter zanesel 6 kilometrov dolg in od 600 do 900 metrov globok plinski oblak. Alžirski vojaki, ki so se bojevali na strani Francije, so bili prve žrtve. V paniki so bežali iz rovov pred smrtonosnim oblakom, ki se je tiho širil po njihovih položajih (Wietzker, 2006, str. 45). Klor se je zaradi svoje teže nakopičil v strelskih jarkih, francoske sile pa so bile zaradi številnih žrtev prisiljene v umik, kar so Nemci izkoristili in zavzeli francoske položaje (Brezina, 2005, str. 23).

Presenečeni antantni branitelji so v drugi bitki pri Ypresu v enem samem dnevu izgubili 18.000 mož, 2000 pa so jih zajele nemške sile. Rumeno-zeleni oblak bojnega plina je uničil vse, česar se je dotaknil. Nad izjemno uničevalno močjo novega orožja niso bili presenečeni samo branitelji, pač pa tudi napadalci. Nemci so si sicer želeli, $\mathrm{v}$ resnici pa niso pričakovali takega uspeha, zato niso imeli pripravljenih dovolj sil, da bi prebili fronto in v celoti izkoristili sovražnikovo presenečenje (Duffy, 2009). Napredovali so 4,5 milje v nasprotnikove položaje, dokler jih ni ustavila hitro improvizirana obramba antantnih sil. Imeli so le primitivno zaščito pred strupenim orožjem, kar je še dodatno oteževalo njihov prodor (Heller, 1984, str. 10). Nemci so v naslednjih dneh napad s klorom še nekajkrat ponovili. Napadli so 24. aprila 1915 kanadske položaje in 2. ter 5. maja britanske, vendar z manj uspeha, saj je bila količina uporabljenega agensa bistveno manjša kot usodnega dne (Hutchinson, 2004, str. 199). Število žrtev plinskega napada še danes ni popolnoma jasno. Antantne sile so imele v enem dnevu vsaj 2500 mrtvih oziroma 4200 pogrešanih (Lejaille, 2013, Vagues allemandes), po nekaterih drugih virih pa so imele približno $5000 \mathrm{mrtvih}$ in od 10.000 do 15.000 ranjenih (Wottke, 2014).

Antantne sile so obsojale nemško uporabo bojnih strupov ${ }^{4}$, po drugi strani pa so tudi same pospešile razvoj kemičnega orožja, da bi ga lahko čim bolj učinkovito uporabile na bojišču (Brezina, 2005, str. 23). Tako pomeni »črni dan Ypresa« trenutek, ko je »duh ušel iz steklenice«, saj so po tem napadu uporabljali kemično orožje v večji meri na obeh straneh. Ta dan je dokazal, da je kemično orožje res učinkovito bojno sredstvo in ima potencial orožja za množično uničevanje. Nemška stran je do konca vojne izvedla še približno 50 plinskih napadov s klorom, pri čemer pa je imela zaradi nenadnih sprememb vetra žrtve tudi v svojih vrstah. Klor so uporabili tako na zahodni kakor tudi na vzhodni fronti. 6. avgusta 1915 so uporabili klor proti ruskim enotam, ki so branile trdnjavo Osowiec, vendar je branilcem kljub plinskemu napadu uspelo obdržati trdnjavo v svojih rokah. Največji napad s klorom so nemške sile izvedle v noči z 19. na 20. januar 1916 pri Reimsu, kjer so izpustili v ozračje 550 ton klora iz 25.000 jeklenk (Duffy, 2009).

\footnotetext{
Svoj protest proti uporabi novega orožja je izrazila tudi žena izumitelja Fritza Haberja Clara Immerwahr, prva promovirana kemičarka v Nemčiji. Po uspešni uporabi klora pri Ypresu si je demonstrativno zadala smrtni udarec in se ustrelila v prsi. Po njenem mnenju bi morala znanost služiti miroljubnemu razvoju človeštva in ne njegovemu uničenju (Brezina, 2005, str. 23).
} 
Po nemškem uspehu pri Ypresu so si tudi Britanci prizadevali uporabiti klor kot orožje. Prvič jim je to uspelo 25. septembra 1915 pri kraju Loos, kjer so izvedli napad s 150 tonami klora. V tem napadu so prvič uporabili možnar, s katerim so izstreljevali projektile s smrtonosnimi kemičnimi agensi, imenovanimi s kodnim imenom rdeča zvezda (angl. Red Star). Nemci so bili na napad slabo pripravljeni. Strupeni plin je preprečil nemškim častnikom in podčastnikom, da bi iz zaščitnih mask dovolj glasno poveljevali, zaradi česar njihovi podrejeni niso slišali njihovih ukazov (Heller, 1984, str. 11). Sicer pa je bil kemični napad polom, saj se je zaradi šibkega vetra plin zadržal na območju nikogaršnje zemlje, deloma pa ga je zaneslo celo Britancem v lastne vrste. Zaradi te grozljive izkušnje so Britanci pospešili raziskave na področju zaščite in izdelali flanelasto plinsko masko. 9. in 19. januarja so uporabili v napadu pri Fromellesu mešanico iz 80 odstotkov klora in 20 odstotkov žveplovega klorida (A short History of CW during WWI., online). Francozi so prve obrate za proizvodnjo klora odprli leta 1915 z britansko pomočjo. Prvi plinski napad s klorom pa so izvedli šele 15. februarja 1916 pri Reimsu. V primerjavi z Britanci niso izpuščali plina iz jeklenk, temveč so kot glavno orožje uporabljali granate s kemičnimi agensi (A short History of CW during WWI., online). Zaradi žrtev v lastnih vrstah so si na obeh straneh prizadevali razviti izstrelke, s katerimi bi izstrelili kemične agense na nasprotnikove položaje in ne bi ogrožali svojega moštva (Duffy, 2009).

\section{FOSGEN - TIHI UBIJALEC}

Fosgen je leta 1812 odkril angleški kemik John Davy, ki ga je uporabljal kot kemično barvilo za blago. ${ }^{5} \mathrm{~V}$ bojne namene so ga prvi preizkusili Francozi pod vodstvom kemika Victorja Grignarda. Z njim so želeli preseči pomanjkljivosti klora na bojišču. Klor se na prostem zadržuje kot zeleno-rumen oblak in ga je zelo lahko opaziti, fosgen pa je brezbarven, kar je oteževalo njegovo detekcijo (Lejaille, Introduction). Fosgen je prvič uporabila nemška vojska 31. maja 1915 pri Ypresu na zahodni fronti. Uporabili so mešanico iz 95 odstotkov klora in 5 odstotkov fosgena. Pozneje so nemške enote uporabljale v napadih čisti fosgen (Wottke, 2014). Francozi so fosgen prvič uporabili 21. februarja 1916 pri Verdunu in za njimi so ga za bojevanje uporabljale vse v vojno vpletene države (Ochsenbein, 2007). Maja 1915 so Nemci uporabili fosgen tudi proti ruskim silam pri Bolimówu na Bzuri. Uporabili so 240 ton klora, ki mu je bilo dodanega še 5 odstotkov fosgena. Napad z mešanico klora in fosgena je povzročil več tisoč smrtnih žrtev. Velik napad z mešanico klora in fosgena so izvedli Nemci 19. decembra 1915 pri Wieltjeju v Flandriji, kjer so proti Britancem izpustili 180 ton strupenega plina iz 4000 jeklenk (Brezina, 2005, str. 25). 1. septembra 1917 so na vzhodni fronti na reki Dvini pred Rigo uporabili kombinacijo obeh agensov in pobili tisoče ruskih vojakov, ki so bili zaščiteni le s

\footnotetext{
Fosgen se uvršča v skupino dušljivcev in povzroči hude poškodbe pljuč, pljučni edem, pogosto tudi smrt. V človeško telo prodira izključno skozi dihalne organe. Je brezbarven in negorljiv plin z značilnim vonjem po sveže pokošenem senu. Uporablja se za sintezo pesticidov, barvil, umetnih smol in plastičnih mas (Ušeničnik, 1999, str. 290-291). V prvi svetovni vojni je fosgen povzročal visoko smrtnost zaradi pljučnice, za katero $v$ tistem času še ni bilo antibiotikov (Crone, 1992, str. 18). Posebna lastnost fosgena je, da se učinki navadno pokažejo šele nekaj ur po izpostavitvi. Simptomi so hudo kašljanje in davljenje žrtve (Cobb, 2000).
} 
slabim in neučinkovitim respiratorjem (Heller, 1984, str. 25). Na bojišču so Nemci uporabljali tudi difosgen, s kemijskim imenom triklorometil kloroformat. Fosgenu so dodali kloroform, ki je prehajal skozi tedanje zaščitne maske, in tako pridobili še bolj strupen agens (Jane's, str. 297). Mešanico klora in fosgena so uporabljale tudi antantne sile. Britanci so od junija do novembra 1916 izvedli 110 plinskih napadov z mešanico klora in fosgena na zahodni fronti. Nemci so leta 1917 fosgen spuščali tudi iz letal (Fitzgerald, 2008). V prvi svetovni vojni je fosgen povzročil okoli 80 odstotkov smrti, povzročenih z bojnimi plini (Cobb, 2000).

\section{GORČIČNI PLIN - IPERIT - KRAL BOJNIH STRUPOV}

Iperit je v 19. stoletju odkril angleški kemik Samuel Guthrie, ki je zmešal klor z Žveplom. ${ }^{6}$ Prvič so na bojišču iperit uporabili Nemci ponoči z 12. na 13. julij 1917 pri Ypresu v Belgiji. Tekočino bojnega strupa so uskladiščili v artilerijske granate, ki so jih izstrelili proti sovražniku, in ob eksploziji se je tekočina pretvorila v plinasto stanje. ${ }^{7}$ Antantni zavezniki so po francoskem prizadevanju že v enem letu začeli izdelovati svoj iperit, kar je med drugim pomembno pripomoglo k nemškemu spoznanju, da leta 1919 ne bodo zmogli vojaško parirati močnejši antantni produkciji nevarnega kemičnega sredstva. Poleg tega je bilo na strani zaveznikov tudi dejstvo, da je na zahodni fronti veter v večji meri pihal z zahoda na vzhod, kar je Nemce še dodatno oviralo pri vodenju kemične vojne (Jones, 2014a).

Do konca vojne je iperit zahteval največ smrtnih žrtev med vsemi uporabljenimi kemičnimi orožji tedanjega časa (Cobb, 2000). Nemci so ga uspešno uporabljali na bojišču predvsem v hladnejših mesecih, poleti pa se je izkazal za manj uspešnega (Jones, 2014a). Leta 1918 je kemična vojna dosegla vrhunec. Povprečno vsaka tretja granata je bila polnjena s kemičnim agensom. V spomladanskih ofenzivah leta 1918 so se Nemci še posebej zatekali k uporabi kemičnega orožja. Z njim so blokirali nasprotnikovo logistično oskrbo, onemogočili delovanje artilerije, nevtralizirali močnejše točke nasprotnika in njihove enote so vse pogosteje zahtevale, da bojni strupi spremljajo streljanje pehote in artilerije (Heller, 1984, str. 25). Slikovit primer

\footnotetext{
Zaradi vonja, ki je spominjal na gorčico, so novo sredstvo imenovali tudi gorčični plin in spada v skupino mehurjevcev (angl. mustard gas, nem. Senfgas). Pravzaprav iperit ni plin, temveč slabo hlapljiva tekočina, vendar se je uveljavil tudi za to sredstvo izraz plin (Crone, 1992, str. 18). Francozi so ga poimenovali iperit (fr. Yperite) po mestu, v katerem je bil prvič uporabljen, Nemci pa rumeni križ (nem. Gelbkreuz) po znaku, s katerim so označevali izstrelke, polnjene s tem agensom (Heller, 1984, str. 13). Manjše koncentracije tega strupa povzročijo slepoto, vnetje kože in mehurje, večje pa poškodbo pljuč in zadušitev. Iperit ima grozljivo lastnost, da ne prehaja $v$ telo samo skozi dihala kakor klor, pač pa poškoduje tudi kožo ter povzroči mehurje po vsem telesu, poškodbe vidnih sluznic, dihal ter kostnega mozga in limfatičnega sistema. Gre za tako agresiven agens, da prodira ne samo v človeško tkivo, pač pa celo v materiale, kot so usnje, les, guma ipd. Poleg tega je iperit obstojen tudi pri nizkih temperaturah, pri višjih temperaturah se obstojnost zmanjšuje, poveča pa se možnost nastanka hlapov. Za zaščito ni dovolj plinska maska, potrebna je tudi zaščita kože po celem telesu, za kar pa navadna obleka ni dovolj (Ivanuša, 2008, str. 148). Znaki kontaminacije se lahko pojavijo šele več ur pozneje, tako da žrtve sprva niti ne slutijo, kaj jih je doletelo (Brezina, 2005, str. 25).

Po poročilu Wilhelma Westphala je Haber opozoril generala Ludendorffa, naj Nemčija uporabi iperit le, če namerava $v$ enem letu zmagati $v$ vojni. V nasprotnem primeru bi se po opozorilu Haberja lahko zgodilo, da bi zavezniki izdelovali to smrtonosno orožje sami, zaradi česar Nemčija ne bi bila sposobna nadomestiti kontaminiranih uniform in industrijsko proizvesti zadosti oblačil za vojake. Že samo to dejstvo bi bilo lahko usodno za Nemčijo (Jones, 2014a).
} 
nemške uporabe strupenega orožja je bil aprila 1918 ob zavzetju mesta Armentières. Mesto so bombardirali z iperitom tako silovito, da so priče omenjale tekoči iperit, ki je tekel po ulicah. Britanci so evakuirali prebivalce mesta, ki je bilo tako kontaminirano, da Nemci še dva tedna niso mogli vstopiti (Heller, 1984, str. 27). Leta 1918 so iperit uporabljali tudi Britanci proti nemškim vojakom. Tako so ga med drugim uporabili 13. oktobra 1918 v bližini belgijske vasice Werwick. Med žrtvami je bil tudi pehotni desetnik Adolf Hitler, ki je utrpel začasno oslepitev in ožganine na koži (Hutchinson, 2004, str. 209).

Zaradi zastrašujočih posledic ostaja iperit nevarno bojno sredstvo še danes, čeprav je prepovedan z mednarodnimi konvencijami (Hutchinson, 2004, str. 210). Nekateri vojaški strokovnjaki menijo, da je gorčični plin najbolj nevaren od vseh kemičnih agensov. Iperit je namreč zelo obstojen in po uporabi nevaren za okolico še dolgo časa (Browne, 1995). ${ }^{8}$

\section{PREOSTALI KEMIČNI AGENSI PRVE SVETOVNE VOJNE}

V prvi svetovni vojni so na obeh straneh preizkusili več različnih bojnih strupov, vendar so $\mathrm{v}$ velikih količinah proizvajali in uporabljali samo nekatere izmed njih: klor $(\mathrm{Cl})$, fosgen (karbonilklorid $-\mathrm{CCI}_{2} \mathrm{O}$ ), difosgen (triklorometil kloroformat $-\mathrm{C}_{2} \mathrm{CI}_{4} \mathrm{O}_{2}$ ), klorpikrin (trikloronitrometan $-\mathrm{CI}_{3} \mathrm{CNO}_{2}$ ), hidrogen cianid (cianovodikova kislina - pruska kislina - HCN), cianogen klorid (CCIN) in iperit (bikloroetil sulfid $-\mathrm{C}_{4} \mathrm{H}_{8} \mathrm{CI}_{2} \mathrm{~S}$ ). Slednji so se izkazali za najbolj učinkovite in uporabne na bojiščih. Klorpikrin je prvič uporabila Rusija avgusta 1916, pozneje pa so ga uporabljale vse vojskujoče se sile. Cianovodikovo kislino so prvič na bojišču preizkusili Francozi 1. julija 1916 na Sommi, pozneje so jo uporabljali tudi Britanci in Francozi (Ochsenbein, 2007). Na seznamu agensov, ki so jih še sintetizirali in preizkusili na bojišču, najdemo: brom $(\mathrm{Br})$, hidrogen sulfid $\left(\mathrm{H}_{2} \mathrm{~S}\right)$, cianogen bromid (bromcianid - $\mathrm{BrCN})$, diklorometil eter $\left(\mathrm{C}_{2} \mathrm{H}_{4} \mathrm{Cl}_{2} \mathrm{O}\right)$, metil cianoformat $\left(\mathrm{C}_{3} \mathrm{H}_{3} \mathrm{NO}_{2}\right)$, etil cianoformat $\left(\mathrm{C}_{4} \mathrm{H}_{5} \mathrm{NO}_{2}\right)$, metansulfonil klorid $\left(\mathrm{CH}_{3} \mathrm{CIO}_{2} \mathrm{~S}\right)$, etansulfonilklorid $\left(\mathrm{C}_{2} \mathrm{H}_{5} \mathrm{ClO}_{2} \mathrm{~S}\right)$, etildikloroarzin $\left(\mathrm{C}_{2} \mathrm{H}_{5} \mathrm{AsCl}_{2}\right)$, metildikloroarzin $\left(\mathrm{CH}_{3} \mathrm{AsCl}_{2}\right)$, etildibromoarzin $\left(\mathrm{C}_{2} \mathrm{H}_{5} \mathrm{AsBr}_{2}\right)$, Clark I (difenilarzinklorid - $\mathrm{Cl}_{2} \mathrm{H}_{10} \mathrm{AsCI}$ ), Clark II (difenilarzincianid $-\mathrm{Cl}_{3} \mathrm{H}_{10} \mathrm{AsN}$ ), adamzit (difenilaminoklorarzin $-\mathrm{C}_{12} \mathrm{H}_{9} \mathrm{AsCIN}$ ), kloracetofenon $\left(\mathrm{C}_{8} \mathrm{H}_{7} \mathrm{ClO}\right.$ ) idr. (A short History of $\mathrm{CW}$ during WWI., online in Ochsenbein, 2007).

V začetku vojne Rusija ni bila sposobna proizvajati svojega kemičnega orožja in je bila odvisna od britanske pomoči. Pozneje je razvila tudi svojo industrijo klora, klorpikrina in fosgena, vendar je šlo za bistveno manjšo produkcijo kot v Nemčiji. Rusi so izvedli prve kemične napade pri Kunilovem septembra in oktobra 1916, vendar so imeli velike težave z lastno zaščito, saj niso imeli učinkovitih plinskih mask (A short History of CW during WWI., online).

\footnotetext{
Na območju zahodne fronte so francoski kmetje še 40 let po koncu prve svetovne vojne poročali, da so drevesni štori, kontaminirani z iperitom, še vedno tako nevarni, da sedenje na njih povzroča poškodbe na koži (Browne, 1995).
} 
Američani so se sicer aktivno vključili v vojno šele aprila 1917, dve leti po prvem uspešnem nemškem plinskem napadu na zahodni fronti. Čeprav so se zavedali povečane uporabe kemičnega orožja na evropskih bojiščih, so se začeli na kemično vojno pripravljati šele dva meseca, preden so vstopili v vojno na strani antantnih sil. Tako so prispele prve ameriške enote v Francijo brez znanja in opreme za kemično vojno. V tem pogledu so bili popolnoma odvisni od zaveznikov. Prizadevali so si čim hitreje nadomestiti primanjkljaj z urjenjem vojakov in razvojem protikemične zaščite, vendar v tem niso bili vedno uspešni. Na bojišču so se srečevali s krutim in neslišnim sovražnikom, ki se je širil vsepovsod - zalezel se je v uniforme, hrano, vodo, opremo, orožje in celo v blato v jarkih (Heller, 1984). Zaostajanje v razvoju kemičnega vojskovanja so Američani želeli prekiniti tudi z znanstvenimi raziskavami. Sintetizirali so novo kemično orožje, imenovano levizit (angl. lewisite) po kemiku, ki ga je prvi izdelal, stotniku Winfordu Lee Lewisu. ${ }^{9}$ Šele v zadnjih mesecih vojne so začeli masovno proizvajali to sredstvo in prva pošiljka je prispela na zahodno fronto, ko je bilo že sklenjeno premirje. Zaradi nenadnega premirja je nevarni tovor pristal v Atlantiku (Hutchinson, 2004, str. 210).

\section{PLINSKA VOJNA NA SOŠKI FRONTI}

Kemično orožje sta imeli tudi Avstro-Ogrska in Italija, tako da so bili kemični agensi uporabljeni tudi na slovenskih tleh, saj je bila glavnina ofenzivnega delovanja obeh sil osredotočena prav na soško bojišče. Prvi plinski napad je bil na soški fronti izveden 29. junija 1916 na Debeli Griži (Monte San Michele), ko so avstro-ogrski vojaki odprli jeklenke, napolnjene $\mathrm{z}$ mešanico klora in fosgena. Iz jeklenk so skozi svinčene cevi plin usmerili proti italijanskim položajem. Italijanska vojska ni imela plinskih mask in žrtve so bile velike. Avstrijci izkušenj z uporabo bojnih strupov pred tem niso imeli, pa tudi plinske maske so imele samo posebne enote, zaradi česar je umrlo tudi 40 avstro-ogrskih vojakov. Avstrijska vojska je uporabila to orožje v obupu, saj je italijanska artilerija silovito napadala njihove položaje. Italijani so bili na ta napad popolnoma nepripravljeni. Po njihovih ocenah so v napadu izgubili $6700 \mathrm{mož,} \mathrm{od}$ katerih je bilo 2700 mrtvih. Italijanskega topništva pa strupeni agens ni dosegel in to je odločno odgovorilo na avstrijski plinski napad. Avstrijsko vojaško vodstvo zato napada s plinom ni imelo za posebno uspešnega (Klavora, 2010, str. 133).

Italijanske enote so na soškem bojišču skladiščile bojne strupe, vendar ni zanesljivih poročil, da bi jih res uporabili v boju. Po vojni so na območju fronte odkrili večje število plinskih granat italijanskega izvora (Klavora, 1993). ${ }^{10}$

\footnotetext{
Levizit je sredstvo s podobnim učinkom kot iperit (Crone, 1992, str. 18). Gre za arzenov mehurjevec, ki je v tekoči obliki brez vonja, kadar pa vsebuje nekaj nečistoč, ima vonj po geraniji. Poškoduje kožo in sluznice, težja zastrupitev pa lahko povzroči slepoto (Ivanuša, 2008, str. 153).

${ }^{10}$ Septembra 1998 so v Soči pod mostom nad Avčami odkrili večje število neeksplodiranih italijanskih plinskih granat, napolnjenih s fosgenom. Akcija uničenja je imela zahtevne priprave in precejšen finančni vložek, saj je odlagališče plinskih granat pomenilo resno nevarnost za okolico. Posamezne granate so bile že korodirane, tako da bi bojni strup ob višji temperaturi lahko uhajal v okolje (Ǔ̌eničnik, 1999, str. 289).
} 
Avstro-ogrska vojska je ponovno uporabila fosgen na soški fronti v začetku znamenite dvanajste ofenzive v sodelovanju z zavezniki Nemci. Ofenziva je potekala v Zgornjem Posočju, med Bovcem in Tolminom, temeljila pa je na presenečenju, uporabi bojnega plina in bliskoviti skupni akciji pehote in topništva. Namen plinskega napada je bil doseči gorske hrbte, strma pobočja in ozke doline, v katerih so bile nevarne italijanske topniške kaverne in opazovalnice. Granate in mine z bojnim strupom so prispevali Nemci. Da bi onesposobili italijanske položaje, so centralne sile uporabile granate, polnjene $\mathrm{z}$ dvema kemičnima agensoma, in sicer s plinom difosgenom in agensom, imenovanim tudi clark (difenilarzinklorid). Kombinacija obeh plinov je bila namenska: clark so uporabili, ker je prehajal tudi skozi filter tedanjih plinskih mask. Povzročil je močno kašljanje, kihanje, bolečine v prsih in tudi bruhanje, zato je bila žrtev prisiljena sneti masko. Takoj, ko je vojak snel masko, je vdihnil še difosgen, kar je ob primerni koncentraciji povzročilo smrt. Difosgen so uporabili, ker je obstojen tudi pri nizkih temperaturah. Nemci so vedeli, da imajo Italijani slabe plinske maske ali pa jih sploh nimajo (Klavora, 2010, str. 134). Poleg plinskih min in granat so Nemci pripeljali v Bovško kotlino še plinomete. ${ }^{11}$ Hkratna izstrelitev večjega števila min je omogočila tolikšno koncentracijo plina, da celo plinske maske niso zadostovale. Poleg plinometov so uporabili tudi topove, ki so izstreljevali plinske granate (Klavora, 2010, str. 134). Centralnim silam je bilo v dvanajsti ofenzivi naklonjeno tudi vreme, saj se je megla kot pokrov spustila nad kotlino in še povečala učinek plinskega napada. Plinski napad je trajal dve uri in pol. Plinske enote in artilerija so imele navodila, da v tem času izstrelijo celotno količino granat, najprej tiste z modrim križem, nato pa še tiste z zelenim križem. V tem času se je prostor med Bovcem in Sočo spremenil v eno samo pokopališče. Plinska smrt je pokosila vojake, podgane in tovorne živali (Klavora, 1993). Prizadet je bil predvsem bataljon italijanske brigade Friuli in čeprav po mnenju Klavore plinski napad ni bil odločilen dejavnik, da se je italijanska obramba na Bovškem polju sesula, je oslabil moralo in bojno moč italijanskih vojakov s strahom in paniko, ki ju je povzročil (Klavora, 2010, str. 134).

\section{PSIHOLOŠKI UČINKI}

Zaradi zastrašujočih posledic uporabe kemičnega orožja je to postalo tako fizično kakor tudi psihološko orožje. V vojaških vrstah se je povečeval strah pred plinskim napadom, ki se je v posameznih primerih stopnjeval tudi do panike in živčnega zloma. Vojaki obeh strani so bili prepričani, da je kemično vojskovanje nečloveško, da krši pravila vojskovanja in s svojo krutostjo presega načela humanosti. Vojaki tudi niso bili prepričani, ali je njihova zaščitna maska zares učinkovita ali pa je morda filter že neuporaben. S stopnjevanjem uporabe kemičnega orožja je negotovost povzročala vse več psiholoških težav. Nemški izum iperita je negotovost in strah še povečeval (Fitzgerald, 2008). Psihološki učinek bojnih strupov je nastajal tudi zaradi nevidnega in neslišnega delovanja kemičnih agensov. Problematična je bila zaznava

\footnotetext{
${ }^{\prime \prime}$ Plinomet je bila cev, ki so jo pred uporabo zabili v zemljo in napolnili s plinsko mino, vžig mine pa je bil električni. Plinomete so prvič uporabili že Britanci 4. avgusta 1917 pri Arrasu v Franciji. Plinomet je bila cev, ki so jo pred uporabo zabili v zemljo in napolnili s plinsko mino, vžig mine pa je bil električni (Klavora, 2010).
} 
prisotnosti tega tihega ubijalca oziroma je prepozno odkritje povzročilo tisoče žrtev. Vsi ti dejavniki so ustvarjali vtis misterioznosti bojnih strupov in povečevali strah pred njimi (Burck in Flowerree, 1991, str. 14).

\section{0 ŽRTVE KEMIČNE VOJNE}

Jeklenke, granate in izstrelki, napolnjeni s kemičnim orožjem, so v prvi svetovni vojni pomenili okoli 25 odstotkov uporabljenega streliva na obeh straneh. Kljub izboljšavam plinskih mask in druge zaščitne opreme so strupeni plini zahtevali več kot milijon smrtnih žrtev, kar je slabih pet odstotkov vseh žrtev zaradi orožja. V precej primerih so žrtve sicer preživele napad s plinom, vendar so pozneje zaradi različnih poškodb umrle zaradi bolezni. Po navedbah Prentissa je v prvi svetovni vojni kemično orožje povzročilo 1.296 .000 žrtev, od katerih je bilo 91.000 smrtnih. Te ocene najbrž niso zanesljive, saj je resnično število žrtev verjetno večje. Upoštevati moramo, da so se pri veliko veteranih posledice kemične vojne pokazale šele po vojni, in vprašanje je, koliko teh žrtev je vključenih v uradne številke (A short History of CW during WWI., online).

Med vsemi vojskujočimi se silami so Rusi utrpeli najhujše izgube zaradi kemičnega orožja, in sicer 56.000 mrtvih od skupaj 420.000 žrtev (okoli 11 odstotkov), predvsem zaradi slabe opremljenosti z zaščitnimi maskami. Tabela spodaj prikazuje število žrtev uporabe kemičnih agensov v prvi svetovni vojni po državah. Prikazuje razliko med številom vseh prizadetih in številom smrtnih žrtev, pri čemer je treba upoštevati, da je približno 12 odstotkov vseh prizadetih in preživelih vojakov čutilo posledice kemičnega napada vse življenje, torej tudi po končani vojni (Hutchinson, 2004, str. 210-211).

\begin{tabular}{rl|l|c|}
\multirow{2}{*}{$\begin{array}{c}\text { Tabela: } \\
\text { Žrtve kemičnih } \\
\text { agensov v prvi } \\
\text { svetovni vojni }\end{array}$} & Država & Vse žrtve (smrtne in preživeli) & Smrtne žrtve \\
\cline { 2 - 4 } & Rusija & 420.000 & 56.000 \\
\cline { 2 - 4 } & Nemčija & 191.000 & 9000 \\
\cline { 2 - 4 } & Francija & 182.000 & 8000 \\
\cline { 2 - 4 } & Velika Britanija (vključno s Kanado) & 180.597 & 8109 \\
\cline { 2 - 4 } & Avstro-Ogrska & 100.000 & 3000 \\
\hline & ZDA & 69.975 & 1462 \\
\cline { 2 - 4 } & Italija & 60.000 & 4627 \\
\cline { 2 - 4 } & Skupaj & 1.203 .572 & 90.198 \\
\hline
\end{tabular}




\section{KEMIČNI AGENSI PO PRVI SVETOVNI VOJNI}

Uporaba kemičnega orožja v prvi svetovni vojni je sicer povzročila ogorčenje mednarodne javnosti, vendar je bilo kljub temu med obema vojnama nekaj primerov uporabe kemičnega orožja. Britanci so uporabili kemični agens adamzit v boju proti boljševikom v ruski državljanski vojni leta 1919. Boljševiki so uporabili strupeni plin pri zatiranju upora pod vodstvom Aleksandra Antonova pri Tambovu leta 1920. Tudi španske oblasti so istega leta s kemičnim orožjem zatrle upor v Maroku. Iperit so uporabili Italijani v italijansko-abesinski vojni (danes Etiopija) leta $1935 \mathrm{v}$ razpršeni obliki iz letal, zaradi česar je umrlo ali bilo poškodovanih približno 150.000 ljudi. Prav tako so kemično orožje uporabili Japonci v Mandžuriji proti kitajskemu civilnemu prebivalstvu in vojaškim silam v letih od 1937 do 1945 (Hutchinson, 2004, str. 212-214).

Napredovala je tudi kemijska znanost. Nemški znanstveniki, ki so se ukvarjali z insekticidi, so sintetizirali prve živčne strupe: leta 1936 tabun, leta 1938 sarin in leta 1944 soman. ${ }^{12} \mathrm{Na}$ srečo Nemčija v drugi svetovni vojni tabuna in sarina iz različnih vzrokov ni uporabila na bojišču. Zaloge bojnih strupov, ki so jih imele države med drugo svetovno vojno, so bile ogromne: ZDA so proizvedle 135.000 ton kemičnega orožja, Nemčija 70.000 ton, Velika Britanija 70.000 ton in Japonska 7500 ton. Vse zaloge kemičnega orožja, ki so bile izdelane med drugo svetovno vojno, se ocenjujejo na več kot 600.000 ton (Hutchinson, 2004, str. 216). Nemčija po količini sicer ni prednjačila, vendar je imela kemične agense s precej večjo učinkovitostjo od drugih držav in je napačno predvidevala, da so sovražne države z raziskavami enako napredovale kot nemška kemijska znanost. Razlogi, da večje uporabe kemičnega orožja v drugi svetovni vojni kljub obilnim zalogam ni bilo, so različni. Po eni strani je bila uporaba kemičnega orožja prepovedana, po drugi strani pa so se vpletene strani bale nasprotnikovih povračilnih ukrepov. ${ }^{13}$ Nemčija se je v drugi svetovni vojni bala povračilnih ukrepov zaveznikov, ki so imeli premoč v zraku in bi jo lahko izkoristili za napad na nemško prebivalstvo. Nemške sile so napačno predvidevale, da imajo zavezniki kemično orožje enake uničevalne sile kot Nemci in so se tudi zato bale povračilnih ukrepov (Cobb, 2000, str. 48).

Po vojni so se države spraševale, kako kemično orožje uničiti. Vse do 60. let prejšnjega stoletja je bilo veliko naloženega na zastarelih ladjah in potopljenega sredi oceanov in morij. Od novembra 1945 do aprila 1946 so tudi v Jadranskem morju Američani potopili veliko fosgena, iperita, hidrogen cianida, levizita in cianogen klorida (Baker, 2006, str. 13). Američani so zastarelo kemično orožje potapljali v oceane še leta 1970. S potopitvijo postanejo živčni strupi neučinkoviti in se raztopijo v vodi, toda iperit je netopljiv, oksidira in tvori debelo plast okoli osrednjega dela mase, ki ostane nevarna tudi pod vodo. Ribiči so pogosto poročali o zastrupitvah rib

12 Živčni agensi trajno blokirajo prenos živčnih dražljajev po telesu in povzročajo izgubo nadzora mišic, odpoved dihalnih organov in smrt. Problematični so še posebej, ker učinki niso takojšnji, nimajo vonja in jih je težko izslediti (Cobb, 2000, str. 47).

${ }^{13}$ Nekateri menijo, da Hitler (razen ciklona B proti Judom v koncentracijskih taboriščih) kemičnega orožja ni uporabljal, ker je bil kot vojak v prvi svetovni vojni sam žrtev zastrupitve s plinom (Broyles, 2005). 
z iperitom. Okoljevarstveniki menijo, da so potopljene ladje, nakopičene s kemičnim orožjem, ekološka časovna bomba, ki tiktaka na tleh svetovnih morij in oceanov. Ocene so, da je na morskih tleh odvrženih okoli 500.000 ton kemičnega orožja. Podvodne raziskave so sicer potrdile le majhen vpliv na lokalni ekosistem, vendar se nevarnost z leti ne zmanjšuje (Hutchingson, 2004, str. 225).

Medtem ko je bila uporaba kemičnega orožja po prvi svetovni vojni razmeroma omejena, pa so raziskave na tem področju napredovale tudi po drugi svetovni vojni. Čeprav so nekateri menili, da bo v atomski dobi po iznajdbi in uporabi jedrskega orožja postalo kemično orožje odveč, so kemiki menili drugače (Kessler, 1948). Leta 1953 so odkrili živčni bojni strup, imenovan VX, ${ }^{14} \mathrm{~V}$ 80. pa binarno kemično orožje, ki omogoča lažje uničenje, hkrati pa se strupenost kemikalije s časom skladiščenja ne zmanjšuje (Cobb, 2000, str. 48). ${ }^{15}$

Tudi v spopadih po drugi svetovni vojni so bile odločitve za uporabo kemičnega orožja precej redke (na primer Irak, ki je uporabil kemično orožje v vojni proti Iranu (Jogan, 1993)). Prav tako je leta 1988 Saddam Hussein uporabil kemično orožje (najverjetneje iperit, VX in sarin) v napadu na Kurde v Severnem Iraku (Broyles, 2005). V času hladne vojne so Sovjetska zveza in ZDA imele več kot 100.000 ton kemičnega orožja, kar naj bi zadostovalo za uničenje celotne človeške populacije na zemlji (Jerič, 2013). Za bojne namene naj bi bili v tem obdobju najbolj uporabni iperit in živčni strupi (Crone, 1992). V vietnamski vojni so ZDA v boju proti silam Viet Conga uporabile herbicide oziroma defoliante v obilnih količinah (več deset milijonov litrov). Pri tem je bil posebej uničevalen herbicid s kodnim imenom Agent Orange, ki so ga prašili po gozdovih in poljih. Namen je bil uničiti gozdove, ki so dajali zavetje vietnamskim vojaškim silam. Tako je bilo uničeno rastlinje na okoli 13 odstotkih površine Južnega Vietnama. Čeprav so ZDA trdile, da so uporabile kemikalije samo v obrambne namene, so z njimi povzročile resne zdravstvene težave in številne zastrupitve ter telesne poškodbe, zaradi katerih je trpelo več sto tisoč ljudi. Uporabile so namreč pesticid, ki vsebuje dioksin, ta pa povzroča raka, razvojne nepravilnosti pri novorojenčkih in druge trajne zdravstvene težave (Brezina, 2005, str. 26). Izkazalo se je, da je imela raba tega pesticida posledice tudi za zdravje ameriških vojakov, njihovih potomcev in ne le vietnamskih prebivalcev (Broyles, 2005). ${ }^{16}$

\footnotetext{
${ }^{14}$ VXje po učinkih podoben tabunu in sarinu, vendar precej bolj nevaren zaradi večje obstojnosti. Kot plin lahko ostane aktiven še tri do štiri tedne po uporabi, smrten pa je že v majhnih koncentracijah (Cobb, 2000, str. 48).

${ }^{15}$ Gre za dve prekurzorski spojini, ki se tik pred uporabo zmešata, pri čemer nastane strupena oblika spojine (Cobb, 2000, str. 48).

${ }^{16}$ Kemično orožje je izdelovala tudi socialistična Jugoslavija v skrivnih obratih Jugoslovanske ljudske armade, v največjih količinah v 80. letih prejšnjega stoletja. Najbolj znani so obrat v vasi Potoci v bližini Mostarja, obrat $v$ Lučanih v Srbiji in tovarna Prva iskra v Bariću v Srbiji (Tihi, 2001). Prednost so dajali predvsem sarinu, ki so ga izdelovali $v$ večjih količinah, druge bojne strupe pa so sintetizirali predvsem eksperimentalno. Sarin je JLA prodajala arabskim državam, med drugim tudi Iraku za boj proti Kurdom (Jurilj, 2013).
} 


\section{UPORABA KEMIČNEGA OROŽJA V TERORISTIČNE NAMENE}

Kemično orožje za svojo izdelavo ne zahteva izjemno visoke tehnologije, pa tudi posebno visokih finančnih sredstev ne, zato je privlačno za uporabo v teroristične namene. Po Barnabyju je kemično orožje najbolj dosegljivo teroristom. Za izdelavo zadostuje znanje kemije in dostop do laboratorija - nekateri bojni strupi pa se lahko izdelajo celo v kuhinji ali kleti. Poleg tega je mogoče proizvodnjo bojnih strupov prikriti v civilni kemični ali farmacevtski industriji. Zato velja kemično orožje za jedrsko bombo siromakov (v Šket Jarm, 2006, str. 45). Kemikalije, iz katerih se lahko kemično orožje izdela, uporablja kemična industrija za najbolj vsakodnevne namene (npr. za izdelavo zobne paste, pesticidov, kozmetike, v tiskarnah, medicini itn.) (Ciraj, 1999). Znanih je več kot 50.000 različnih kemikalij, ki bi se jih lahko uporabilo kot kemično orožje (na primer klor). Izdelava bomb je precej preprosta in v knjižnicah je dostopna literatura s shematičnimi opisi tega orožja iz časa prve svetovne vojne (Reddy, 2007). Kemični agensi se lahko uporabijo v zaprtih prostorih ali se z njimi kontaminirata hrana in voda (Cobb, 2000, str. 33). Kemično orožje tako predstavlja »orožje prihodnosti« in ima potencial destabilizacije varnostnega sistema ter njegovega zloma (Podbregar in Ivanuša, 2013).

V 20. stoletju je bilo kemično orožje uporabljeno leta 1946, ko je skupina Maščevanje izraelske krvi (hebrejsko Dahm Y'Israel Nokeam) želela z arzenikom zastrupiti pripadnike SS v vojaškem kompleksu zaporov blizu Nürnberga, da bi maščevala žrtve holokavsta (Tucker, 2000, 250). Kemično orožje je v terorističnih akcijah večkrat uporabila tudi japonska verska sekta Aum Shinrikyo. Najbolj odmevna je bila njena akcija leta 1995 na podzemni železnici v Tokiu, ko je bilo zaradi uporabe živčnega bojnega strupa sarina poškodovanih 5510 ljudi, umrlo pa jih je 12 (Seto, 2001). Pripadniki sekte so sarin izdelovali sami ${ }^{17}$, zato njegova koncentracija ni bila največja in je bilo število smrtnih žrtev razmeroma nizko, ob boljši kakovosti pa bi povzročil tisoče mrtvih (Cobb, 2000, str. 55).

Primer Aum Shinrikyo odkriva tudi negativne strani uporabe kemičnega orožja. Problematično je namreč razprševanje strupenega sredstva, pa tudi skladiščenje $\mathrm{v}$ ohišju, ki preprečuje izhlapevanje. To so dejavniki, ki otežujejo morebitno izdelavo kemičnega orožja manjšim skupinam brez posebnega znanja in materialov. Teroristi lahko razširijo kemično orožje po prostoru s pomočjo ventilatorjev (Matsumoto, 1994), vrečk s strupi (Tokio, 1995), bomb s strupi (npr. v avtomobilih), razpršilcev, ki so nameščeni na letalih (npr. za škropljenje njiv) itn. Kemično orožje lahko tudi primešajo hrani in vodi (Burck in Flowerree, 1991, str. 585).

Kemično orožje pa ni bilo uporabljeno samo za teroristične namene, temveč tudi za nekatere protiteroristične akcije. Najbolj odmevna je bila akcija ruskih specialnih sil v moskovskem gledališču Dubrovka oktobra 2002, ko je bilo v boju proti čečenskim teroristom uporabljeno kemično orožje neznane sestave. Čečenski teroristi so

\footnotetext{
${ }^{17}$ Sarin namreč odlikujeta enostavna izdelava in dostopnost sestavin. Recept za izdelavo sarina je bil podoben tistemu, ki ga je uporabljala sovjetska armada in najverjetneje so ga pripadniki kupili od visokega predstavnika ruskih oblasti (Kaplan, 2000, 213-216).
} 
ugrabili kar 850 gledalcev in igralcev ter jih imeli v gledališču kot talce. Po uporabi skrivnostnega kemičnega orožja je bilo vseh 40 do 50 čečenskih teroristov mrtvih in poleg njih še 129 talcev. Čečenski teroristi so bili sicer žrtve strelnega orožja specialnih sil, toda talci so podlegli neznanemu kemičnemu plinu, ki je poškodoval tudi nekaj pripadnikov specialnih sil (Krechetnikov, 2012).

\section{PRAVNE PREPOVEDI UPORABE KEMIČNEGA OROŽJA}

Ob koncu 19. stoletja so se evropske sile že zavedale morebitne nevarnosti novega orožja in so hotele omejiti njegov razvoj in uporabo. Primer je sprejetje Haaške konvencije leta 1899 in Haaške konvencije o kopenskem vojskovanju leta 1907, ki sta prepovedali uporabo projektilov, polnjenih s strupi, in strupenih plinov v bojne namene (Höfer, 2002). Ne glede na sprejetje obeh konvencij pa je bilo do konca prve svetovne vojne proizvedenih več kot 124.000 ton bojnih strupov. Izrazoslovje obeh konvencij je bilo slabo izbrano in zato so določila dopuščala različne interpretacije, ${ }^{18}$ konvencij pa niso upoštevale niti centralne niti antantne sile (Fitzgerald, 2008).

Po Veliki vojni je mednarodna skupnost želela urediti področje pravnih omejitev uporabe kemičnega orožja. Z mirovno pogodbo v Versaillesu leta 1919 je bila tako Nemčiji prepovedana proizvodnja kemičnega orožja (Broyles, 2005). Leta 1925 je bil v Ženevi podpisan Protokol o prepovedi vojaške uporabe plinov in bakterioloških metod vojskovanja. Ta protokol, znan kot Ženevski protokol, je prepovedal uporabo kemičnega orožja v vojni, ni pa prepovedal skladiščenja, proizvodnje in razvoja kemičnega orožja (Ciraj, 1999, str. 285). Protokola nista podpisali Japonska in ZDA. Ženevski protokol so ZDA ratificirale šele leta 1975, potem, ko so uporabile pesticide v vietnamski vojni v vojaške namene (Brezina, 2005, str. 25-27).

Odločitev za pripravo bolj obvezujočega dokumenta o prepovedi kemičnega orožja je bila sprejeta na konferenci o razoroževanju leta 1980. Pogajanja so se zavlekla vse do 90. let, zaradi česar je bil Ženevski protokol edina mednarodna pravna omejitev uporabe kemičnega orožja vse do leta 1993 (Brezina, 2005, str. 27). Konvencijo o kemičnem orožju (Chemical Weapons Convention) je 13. januarja 1993 slovesno podpisalo 150 držav, med njimi tudi Slovenija. V svetovnem merilu je začela veljati 29. aprila 1997. Konvencija določa prepoved razvoja, proizvodnje kemičnega orožja in obvezno uničenje njegovih zalog. Dovoljuje rabo nekaterih kemičnih agensov, na primer solzivca, v policijske namene, vendar zahteva, da imajo sredstva, uporabljena $\mathrm{v}$ te namene, le kratkotrajne učinke, ki ne puščajo resnih zdravstvenih posledic. Leta 1997, ko je začela konvencija veljati, sta ZDA in Rusija posedovali okrog 95 odstotkov svetovnih zalog kemičnega orožja. ZDA načrtujejo, da bodo uničile vse zaloge kemičnih agensov do leta 2021, Rusija pa do leta 2015 (Jane's, str. 11 in 12). Za uresničevanje določb konvencije na svetovni ravni je bila ustanovljena Organizacija za prepoved kemičnega orožja (Organisation for the Prohibition of Chemical Weapons; v nadaljevanju OPCW) (Ciraj,1999, str. 285). OPCW ima sedež v Haagu

18 Tako so Nemci trdili, da so pri Ypresu uporabili jeklenke, iz katerih se je širil klor, česar po njihovem mnenju konvenciji nista prepovedovali, saj sta omenjali le projektile z bojnimi strupi (Hutchinson, 2004, str. 199). 
na Nizozemskem, njena naloga pa je preverjati, kako države spoštujejo Konvencijo o kemičnem orožju, lahko pa v posamezno državo pošlje tudi inšpektorje (Jerič, 2013). Vsaka država podpisnica omenjene konvencije je tudi članica OPCW, kar pomeni, da so zunaj organizacije le še štiri države, in sicer Angola, Egipt, Severna Koreja in Južni Sudan.

\section{KEMIČNA NEVARNOST DANES}

Danes poskuša mednarodna skupnost z delovanjem Organizacije za prepoved kemičnega orožja zmanjšati nevarnost nastanka zaradi kemičnih agensov škodljivih posledic za človeštvo. Ne glede na pravne prepovedi pa zveza Nato pojmuje nevarnost kemičnih sredstev in JRKB-orožij kot še vedno prisotno in celo bolj nevarno od klasičnega orožja. Toksične industrijske nevarnosti so samo del tega. Skladno s tem zahteva Nato od svojih članic tudi, da poskrbijo za ukrepe JRKB-obrambe (AJP-3(B), str. 1-16). Koncept upravljanja naravnih in industrijskih nevarnosti (angl. Concept for the Management of Environmental Industrial Hazards) vključuje širok spekter tveganj na območju delovanja oboroženih sil. Nevarnosti se nanašajo na nameren ali nenameren izpust toksičnih kemičnih agensov v okolje. Pristop k upravljanju vseh vidikov JRKB-nevarnosti opredeljuje tudi Natova doktrina AJP 3.8 Allied Joint Doctrine for NBC Defence. Doktrina zahteva od članic, ki prispevajo svoje enote v operacije zavezništva, sposobnost identifikacije, opozarjanja in poročanja v enotah ranga čete, ob toksičnih industrijskih incidentih pa zagotoviti primerno individualno in kolektivno zaščito. Tako ostaja naloga vsake posamezne države, da poskrbi za sredstva za protikemično zaščito, detekcijo in dekontaminacijo ter ohranja znanje o njihovi uporabi (Ivanuša, 2008, str. 156).

Sklep Izkušnja o uporabi kemičnega orožja v prvi svetovni vojni in o njegovih uničevalnih lastnostih je pomembna tudi za današnji čas. Po eni strani nam kaže učinek posameznih bojnih strupov na ljudeh, po drugi strani pa pripomore k razvoju zaščitnih sredstev in potrebnih medicinskih ukrepov za pomoč prizadeti civilni in vojaški populaciji. Ne glede na prepoved proizvodnje, kopičenja in uporabe kemičnega orožja pa njegova razmeroma poceni in preprosta izdelava pomeni stalno grožnjo za zdravje in življenje tako civilnega prebivalstva kakor tudi vojaških oseb. Posledice rabe nekaterih bojnih strupov so danes popolnoma enake kot tiste iz obdobja od 1914 do 1918, kar potrjuje, da so izkušnje iz prve svetovne vojne neprecenljive in še vedno uporabne.

Obdobje prve svetovne vojne je pomenilo preizkušanje različnih vrst kemičnega orožja in pokazalo njegove učinke in uspešnost rabe v boju. Izkazalo se je, da ima kemično orožje sicer lahko močnejše učinke na nasprotnikove enote, vendar je precej odvisno od vremenskih razmer, saj ob spremembi vremena lahko povzroči žrtve v lastnih vrstah, kar pomeni, da ni popolnoma zanesljivo. Izjemen razmah uporabe kemičnega orožja v prvi svetovni vojni ni vplival na končni izid vojne, saj se bojni strupi na bojišču niso vedno izkazali kot najbolj učinkoviti in še manj zanesljivi. Pokazalo se je, da so kemikalije, ki so ostale v vodi in zemlji, prav tako 
nevarne za napadalce kakor za sile v obrambi. To so tudi najpomembnejši vzroki, da se kemično orožje po letu 1918 ni več uporabljalo v takem obsegu, kot je značilno za prvo svetovno vojno. Čeprav si je mednarodna skupnost prizadevala z deklaracijami čim bolj omejiti proizvodnjo in uporabo kemikalij v bojne namene, pa sta glavna dejavnika, ki sta odvračala od njegove uporabe, nepredvidljivost in nevarnost tega orožja tudi za tistega, ki je bojne strupe uporabil. Prva svetovna vojna je že pokazala, da ima kemično orožje močan psihološki učinek in deluje zastraševalno ter povzroča zmedo in negotovost. Kemično orožje se je pozneje izkazalo za manj uporabno v vojaške namene, po drugi strani pa ima lastnosti, ki ga delajo učinkovitega za teroristične akcije. Izdelava kemikalij je precej poceni, njena uporaba pa povzroči paniko, močan odziv javnosti in posledice lahko ostanejo na prizadetem območju še daljši čas. Podzemni objekti, v katerih se zadržuje veliko ljudi, so še posebej privlačna tarča za kemični terorizem, saj se v njih kemične snovi zadržujejo dalj časa in lahko povzročijo več žrtev. Tako pomenijo kemični agensi danes nevarnost predvsem za uporabo $\mathrm{v}$ teroristične namene in manj kot bojno sredstvo, predvsem zaradi prizadevanja mednarodne skupnosti po globalnem izničenju teh nevarnih snovi.

1. A short History of Chemical Warfare during World War I. The Wayback Machine. https:// web.archive.org/web/19991023051711/http://www.mitretek.org/mission/envene/chemical/ history/ww1.html, 25. 8. 2014.

2. AJP-3(B), 2011. Allied joint doctrine for the conduct of operations. str. 1-16, http://www. cicde.defense.gouv.fr/IMG/pdf/20110316_np_otan_ajp-3b.pdf, 12. 8. 2014.

3. Baker, D., 2006. Biological, Nuclear \& Chemical Weapons. Florida: Rourke Publishing by Discovery Books.

4. Brezina, C., 2005. Weapons of Mass Destruction. Proliferation and Control. New York: The Rosen Publishing Group.

5. Browne, W. M., 1995. Terror in Tokyo: the Poison; Sarin Just One of Many Deadly Gases Terrorists Could Use. The New York Times. http://www.nytimes.com/1995/03/22/world/ terror-tokyo-poison-sarin-just-one-many-deadly-gases-terrorists-could-use.html, 17. 7. 2014.

6. Broyles, J., 2005. Chemical and Biological Weapons in a Post-9/11 World. New York: The Rosen Publishing Group.

7. Burck, M. G. and Flowerree, C. C., 1991. Chemical Weapons Proliferation. New York: Greenwood Press.

8. Ciraj, M., 1999. Konvencija o kemičnem orožju in njeno uresničevanje v Republiki Sloveniji. Ujma - revija za vprašanja varstva pred naravnimi in drugimi nesrečami. Str. 284-288.

9. Cobb, B. A., 2000. Biological and Chemical Weapons. The Debate Over Modern Warfare. New York: The Rosen Publishing Group.

10. Crone, D. H., 1992. Banning chemical weapons. The scientific background. Cambridge: University press.

11. Duffy, M., 2009. Weapons of War-Poison Gas. http://www.firstworldwar.com/weaponry/ gas.htm, 6. 8. 2014.

12. Fitzgerald, J. Gerard, 2008. Chemical Warfare and Medical Response During World War I. Am J Public Health. http://www.ncbi.nlm.nih.gov/pmc/articles/PMC2376985, 6. 8. 2014. 
13. Heller, E. C., 1984. Chemical Warfare in World War I: The American Experience, 19171918. V: Leaveanworth Papers, št. 10. Fort Leavenworth: Combat Studies Institute. http:// webharvest.gov/peth04/20041017045619/http://www.cgsc.army.mil/carl/resources/csi/ Heller/HELLER.asp, 28. 8. 2014.

14. Höfer, M., 2002. Chemische Kampfstoffe. V: Chemie in unserer Zeit. Št. 3, str. 148-155. http://www.cci.ethz.ch/vorlesung/de/Chemiegeschichte/Chemiewaffen.pdf, 28. 8. 2014.

15. Hofmann, S. J., 2014. Der erste Einsatz von Giftgas als Kriegswaffe. http://www.dw.del der-erste-einsatz-von-giftgas-als-kriegswaffela-17053767, 15. 7. 2014.

16. Hutchinson, R., 2004. Weapons of Mass Destruction. London: Cassell Military Paperbacks.

17. Ivanuša, T., 2008. Kemično orožje. V: Terorizem in jedrska, radiološka, kemična ter biološka obramba. Ljubljana: PDRIU, str. 137-172.

18. Jane's Nuclear, Biological and Chemical Defence 2011-2012, Surrey: IHS Jane's, IHS Global Limited, Sentinel House, Alexandria: Jane's Information Group Inc.

19. Jerič, P. A., 2013. Kemično orožje-jedrska bomba revnejših držav, http://www.rtvslo.si/ svet/kemicno-orozje-jedrska-bomba-revnejsih-drzav/317585, 20. 8. 2014.

20. Jogan, S., 1993. Začetek konca orožja za množično uničevanje. Teorija in praksa. 9-10, str. 999-1003.

21. Jones, S., 2014a. Yellow Cross: the advent of Mustard Gas in 1917. http:// simonjoneshistorian.wordpress.com/2014/02/04/yellow-cross-the-advent-of-mustard-gasin-1917/, 18. 8. 2014.

22. Jurilj, Z., 2013. Kako je otrov sarin iz Mostara završio u Iraku. Što je ostalo od tvornice bojnih otrova bivše JNA u Potocima kod Mostara. Večernji list. http://www.vecernji.ba/ kako-je-otrov-sarin-iz-mostara-zavrsio-u-iraku-613914, 25. 8. 2014.

23. Kaplan, E. D., 2000. Aum Shinrikyo. V: Toxic terror : assessing terrorist use of chemical and biological weapons. Cambridge: MIT Press, str. 207-226.

24. Kessler, F., 1948. Der chemische Krieg. V: Protar, št. 1-2, ETH-Bibliothek, Zürich, http://retro.seals.ch/cntmng?pid=zbk-001:1948:14::171, 15. 7. 2014.

25. Klavora, V., 1993. Plavi križ: Soška fronta: Bovec 1915-1917. Koper: Lipa.

26. Klavora, V., 2010. Uporaba bojnih plinov na soškem bojišču v letih 1916-1917. V: Soška fronta 1915-1917. Kultura spominjanja. Dunaj: Slovenski znanstveni inštitut; Ljubljana: Založba ZRC.

27. Krechetnikov, A., 2012. Moscow theatre siege: Questions remain unanswered. BBC News Europe. http://www.bbc.com/news/world-europe-20067384, 23. 7. 2014.

28. Legg, J., Parker, G., 2002. The Germans develop a new weapon: the gas cloud. The Great War. http://www.greatwar.co.uk/battles/second-ypres-1915/prelude/gas-development.htm, 30. 7. 2014.

29. Lejaille, A., 2013. Introduction: Prelude a la Grande Guerre Chimique. http://www. guerredesgaz.fr/these/Introduction/introduction.htm, 1. 9. 2014.

30. Lejaille, A., 2013. Vagues allemandes. http://www.guerredesgaz.fr/Agression/Lesvagues/ Allemandes/Allemandes.htm, 1. 9. 2014.

31. Ochsenbein, A., 2007. Dossier Chemische Kampfstoffe. Kampfstoff Ersteinsätze während dem 1. Weltkrieg. http://www.dtig.org/docs/BCW_3.pdf, 1. 9. 2014.

32. Podbregar, I. in Ivanuša, T., 2013. Proliferacija orožja za množično uničevanje - JRKB/E: novodobni izziv varnostnim silam v boju proti terorizmu. Sodobni vojaški izzivi. 4, str. 121-128.

33. Seto, Y., 2001. The Sarin Gas Attack in Japan and the Related Forensic Investigation. http://www.opcw.org/news/article/the-sarin-gas-attack-in-japan-and-the-related-forensicinvestigation/, 28. 7. 2014.

34. Šket Jarm, V., 2006. Orožje za množično uničevanje v Iranu, Iraku in Severni Koreji. Magistrsko delo. Ljubljana: Fakulteta za družbene vede. 
35. Reddy, C., 2007. The Growing Menace of Chemical War. http://www.whoi.edu/page. do? pid $=7342 \&$ tid $=282 \&$ cid $=25749$.

36. Tihi, Z., 2001. Kemijsko oružje iz Mostara. http://www.aimpress.ch/dyn/pubs/archive/ data/200111/11120-001-pubs-sar.htm, 18. 8. 2014.

37. Tucker, B. J., 2000. Lessons from the Case Studies. v: Toxic terror : assessing terrorist use of chemical and biological weapons. Cambridge: MIT Press, str. 249-269.

38. Ušeničnik, B., 1999. Odstranjevanje plinskih granat iz reke Soče. Ujma-revija za vprašanja varstva pred naravnimi in drugimi nesrečami, str. 289-294.

39. Wietzker, W., 2006. Giftgas im Ersten Weltkrieg. Was konnte die deutsche Öffentlichkeit wissen? Inaugural-Dissertation. Düsseldorf: Die Philosophische Fakultät der HeinrichHeine-Universität Düsseldorf.

40. Wottke, D., 2014. Kampfgas. http://www.alstergymnasium-hu.de/content/ProjektGeschichte/sites/mtg_kampfgas.html\#blaukreuz, 25. 8. 2014. 


\title{
VOJAŠKOGEOGRAFSKA RAZSEŽNOST DOBRUDŽE IN (SLOVENSKI) PROSTOVOLJCI NA TEM BOJIŠČU V PRVI SVETOVNI VOJNI
}

\author{
MILITARY GEOGRAPHICAL DIMENSION \\ OF DOBROGEA AND (SLOVENIAN) VOLUNTEERS \\ IN THIS BATTLEFIELD IN WORLD WAR I
}

Povzetek Predstavljena je Dobrudža, geografska regija v jugovzhodnem delu Evrope, ki ima pomembne vojaškogeografske, geostrateške in geopolitične značilnosti. Določajo jih bližina kriznih žarišč, občasna mednacionalna trenja na širšem območju Podonavja, zgodovinska dediščina in geoprometna pomembnost. V prispevku so predstavljene splošne in fizične geografske danosti območja. Prikazan je razvoj prostorskih struktur, ki odločilno vplivajo na geoprometni položaj regije. Osrednji del prispevka predstavlja Dobrudžo kot bojišče operativnih razsežnosti in udeležbo Slovencev v bojih ter operacijah prve svetovne vojne na vzhodnem in jugovzhodnem bojevališču. Nakazane so nekatere sodobne geopolitične in geostrateške značilnosti območja. Zadnji del prispevka opozarja na vojaškogeografsko razsežnost in pomen Dobrudže zaradi bližine kriznih žarišč in nestabilnosti obrobja Črnega morja.

Ključne Prva svetovna vojna, vzhodna fronta, prostovoljci, Dobrudža, površje, geopolitika, besede vojaška geografija, vojaška zgodovina, smeri, prometne povezave, pristanišča, vojaške baze, podnebje, hidrologija.

Abstract We are presenting Dobrogea, a geographical region in south-eastern part of Europe with important military geographical, geostrategic and geopolitical characteristics. These are determined by the proximity of crisis areas, occasional international frictions in the wider Danube Basin, historical heritage and geostrategic importance. The article presents general and physical geographic resources of the area. It illuminates the development of spatial structures which decisively impact the geotraffic situation of the region. The main part of the article presents Dobrogea as a battlefield with operational dimensions, and the participation of Slovenians in World War I battles and operations in eastern and south-eastern battlefields. It points to some of the contemporary geopolitical and geostrategic characteristics of the region. The final part of the article, however, brings attention to the military geographical 
dimension and the importance of Dobrogea due to the proximity of crisis areas and instabilities of the Black Sea fringe.

Key words World War 1, Eastern Front, volunteers, Dobrogea, relief, geopolitics, geostrategy, military geography, military history, routes, transport networks, ports, military bases, weather, hidrology.

Uvod Dobrudža ${ }^{1}$ je pomembna geostrateška, geopolitična in vojaškogeografska regija, ki jo pri nas slabo poznamo. Njen pomen se je povečal po spremembi vojaškega, geostrateškega in geopolitičnega razmerja z rusko zasedbo in priključitvijo polotoka Krima.

Letos mineva sto let od začetka prve svetovne vojne. Ta je zelo zaznamovala tudi Slovence. Kot vojaki avstro-ogrske monarhije so bili poslani na vzhodno fronto, kjer so jih veliko tudi zajeli. Iz ruskega ujetništva so se kot prostovoljci vključili v sestav zavezniške srbske vojske ter skupaj z ruskimi in romunskimi enotami sodelovali v odločilnih spopadih proti nemškim, bolgarskim in turškim oboroženim silam na poljanah Dobrudže.

Pri nastajanju tega prispevka ${ }^{2}$ so bili uporabljeni zgodovinski viri in zapisi udeležencev spopadov leta 1916, pogovori in intervjuji s prebivalci posameznih krajev v Dobrudži, ogled in primerjava posameznih območij z zapisi ter neposredno iskanje ostalin prve svetovne vojne.

\section{GEOGRAFSKI POLOŽAJ, VELIKOST IN OBLIKA TER MEJE OBMOČJA}

Dobrudža je mejna geografska regija med Romunijo in Bolgarijo, južno od spodnjega toka Donave in obalno območje ob zahodnih obalah Črnega morja. Leži v pasu $44^{\circ}$ severne geografske širine in $28^{\circ}$ vzhodne geografske dolžine. Meri $23.262 \mathrm{~km}^{2}$ (Klemenčić, 1997, str. 433). Je nekoliko večja od Slovenije in trapezaste oblike. Nima izrazitega središča. Na vzhodu jo omejuje obala Črnega morja. Njen skrajni severovzhodni del sega od delte Donave ${ }^{3}$ med mestom Tulcea ${ }^{4}$ in krajem Murighiol. Romuni ta del Dobrudže, ki obsega pokrajino proti jugozahodu do kanala DonavaČrno morje med krajem Cernavodă in mestom Constanca, poimenujejo Dobrogea de Nord. Upravni središči tega območja sta Tulcea in Constanca. Proti jugozahodu sega

\footnotetext{
Ime Dobrudža je zapisano fonetično in je enako, kot se izgovori v bolgarščini. V romunščini je zapisano kot Dobrogea. Za lažje branje je v nadaljevanju uporabljen izraz Dobrudža.

2 Zahvaljujem se doc. dr. Zvonimirju Bratunu, ki je prvotno sodeloval pri sestavi in oblikovanju tega prispevka. Zaradi nestrinjanja z recenzenti se je umaknil iz nadaljnjih postopkov ter dejanj, povezanih s prispevkom. Kljub temu mi je prepustil svoj del v prispevku, fotografije in Dnevnik potovanj.

3 Nekateri romunski avtorji k Dobrudži prištevajo tudi delto Donave. Glej zemljevid Dobrudže v: http://en.wikipedia.org/wiki/Dobruja\#mediaviewer/File:Dobrudja_topographic_map-en.svg.

${ }^{4}$ Vsa geografska imena za del Dobrudže, ki je v Romuniji, so zapisana enako kot na karti Dobrogea de Nord si Delta Dunării v merilu 1 : 100.000, Cartografie digitalila, Georgata, DURA, 2005 in na karti Romănia - Harta Rutieră v merilu 1 : 850.000, Florina Folea, Cartografgeograf Elena Grigore.
} 
osrednji romunski del Dobrudže od vzhodnega obrobja mesta Silistra ob Donavi do kraja Varna Veche na obali Črnega morja. Na severu jo omejuje desni breg Donave med mestom Silistra in krajem Cernavodă. Upravno administrativno središče tega dela Dobrudže je Constanca. Geografsko središče obeh delov Dobrudže v Romuniji je Medgidia 5 .

Bolgarski del Dobrudže se razteza od meje z Romunijo, na črti Silistra6 - Varna Veche, do vznožja gričevnatega sveta Ludogorja pri kraju Tervel na zahodu. Nato proti jugu meja poteka v ravni črti do kraja Bjlči dol, obkroži Dobrudžanski plato na vzhodu in doseže Balčik ob Črnem morju. Upravno in geografsko središče bolgarskega dela Dobrudže je mesto Dobrič ${ }^{7}$.

Dobrudžo seka državna meja med Romunijo in Bolgarijo ${ }^{8}$. Od mesta Silistra ob Donavi se mejna črta vleče lomljeno zahodno od območja Oltinaplateu in Negruvodā plateu, tako da večina porečja Suhe ostaja na bolgarski strani. Pri tem seka dolino reke Darea in deset kilometrov južno od pristanišča Mangalia doseže morsko obalo. Najpomembnejši mejni prehodi med Romunijo in Bolgarijo v Dobrudži so Silistra na vzhodnem obrobju istoimenskega bolgarskega mesta, Yovkovo na pol poti med krajema General Toševo in Negruvodā ter Durankulak, kakih 10 kilometrov južno od pristanišča Mangalie.

\section{NARAVNE DANOSTI OBMOČJA}

Dobrudža je planotasta uravnava s podlago iz krednih apnencev. Uravnava je posledica peneplenizacije v terciarju, razen delte Donave in Ludogorja.

Zaradi odprtosti in ravninskega reliefa so v ledenih dobah severni vetrovi na njeno površje nanesli plast rodovitne puhlice. V kvartarju so se v kraško podlago zarezali erozijski jarki in ustvarili vijugave doline. Nanosi gline in ilovice so omogočili zložne prečne prehode dolin in dostope do morske obale v severni Dobrudži. Rudnin v geološki podlagi ozemlja Dobrudže ni. Južna Dobrudža ima zaradi abrazijske moči morja erozijsko in odsekano obalo9 ${ }^{9}$, razen doline Batove zahodno od Balčika.

Površje Dobrudže dosega med 200 in 300 metri nadmorske višine. Najvišja točka je hrib Tutuiatu s 467 metri nadmorske višine. Proti zahodu se uravnava zložno dviguje

\footnotetext{
Bolgarsko poimenovanje tega mesta je Medžižija. To poimenovanje je uporabljeno v nadaljevanju prispevka $v$ delu, ki opisuje vojaške operacije v Dobrudži leta 1916.

${ }^{6}$ Vsa geografska imena za del Dobrudže, ki je v Bolgariji, so zapisana enako kot na karti: Пъmha kapma Българрія (Pytna karta Blgaririja) 1 : 540.000, ДОМИНО (DOMINO), 2008, Cmapa 3aгорa (Stara Zagora).

Na karti Romănia - Harta Rutieră je mesto Dobrič poimenovano kot Tolbuhin (po priimku maršala Rdeče armade, ki je leta 1944 zasedla Dobrudžo) in z romunskim imenom Bazargic.

8 Meja med Romunijo in Bolgarijo je bila v tem delu določena leta 1940 pod patronatom Nemčije. Potrjena je bila s Pariškim dogovorom leta 1947 (Klemenčić, 1997, str. 433). Mejni režim je po vstopu Bolgarije in Romunije v Evropsko unijo enoten.

Glej sliko 2 v prilogi.
} 
v Ludogorje, ki je v večjem delu zunaj obravnavanega območja. Reliefne oblike ${ }^{10}$ površja Dobrudže ne ovirajo močno premika in manevra vojaških vozil. Nakloni površja njenega osrednjega dela dosegajo do $5^{\circ}$. Oklepna prehodnost je dobra, razen pet do deset kilometrov širokega dela pasu vzdolž desnega brega Donave. Izrazitih orografskih ločnic za vkopavanje in izdelavo obrambnih linij ni. Reliefni hrbti ${ }^{11}$ nad dolinami in na stiku geoloških prelomnic z ostanki živoskalnih štrlin pod plastjo preperin omogočajo vkopavanje in hitrejšo izdelavo okopov za ognjene položaje. Prehod z obale proti osrednjemu delu Dobrudže je kanaliziran in omejen zaradi od petdeset do sto metrov visokih klifov med Balčikom, rtom Kaliakra ${ }^{12}$ in jezerom Durankulak. Klifi na tem delu obale se krušijo in niso primerni za plezanje. V pasu med deset in petdeset metri pod površjem so v klifih ostanki kraških jam, ki omogočajo prikrito opazovanje morske površine. Preglednost preostalega območja je dobra. Omejujejo jo dolinski in erozijski jarki med uravnanimi deli ravnine.

Podnebne razmere $\mathrm{v}$ Dobrudži določajo vetrovne razmere in majhna količina padavin. Posledica temperaturnih razlik je premikanje zračnih mas in tokov med kopnim in morjem ${ }^{13}$. Majhna količina padavin je posledica reliefnih pregrad Balkana in jugovzhodnih Karpatov. Njuni gorovji prestrežejo večino padavin, ki jih nosijo fronte iznad Sredozemlja in Atlantika proti Črnemu morju. Izrazito malo padavin pade februarja, septembra pa pade v povprečju 120 mm dežja. Število deževnih dni niha od pet do deset dni na mesec. Povprečne januarske temperature nihajo od -1 do $6{ }^{\circ} \mathrm{C}$, najvišje letne, za julij in avgust, pa od 18 do $27^{\circ} \mathrm{C}$.

Večina površinskih vod v zahodnem delu Dobrudže so ponikalnice. Znaten del teh vodotokov je reguliranih in zajezenih z akumulacijskimi jezeri, ki omogočajo namakanje poljedelskih površin v sušnem obdobju. Pomembnejši kraški vodotoki so Suha v vznožju Ludogorja na bolgarski ter Negrasti in Negruvoda na romunski strani. V Črno morje se izlivajo Gatava, Albesti in Ascila. Večina vodotokov na severovzhodu je speljana v kanal Donava-Črno morje, ki od kraja Murfatair poteka po dolini reke Negru vodā. V kanal se stekajo številni bočni pritoki s planote nad krajem Medgidia (Medžižje $\left.{ }^{14}\right)$.

Proti severu se zaradi zložno spuščajočega se reliefa k obalam Črnega morja širi pas lagunskih jezer $\left(\right.$ limanov $^{15}$ ) vse do delte Donave. Pritoki Donave v Dobrudži so kratki in hudourniški. Višinske razlike med izviri in izlivi hudournikov na desnem bregu Donave ustvarjajo svet grap in erozijskih jarkov. Med mestom Silistra in krajem Cernavodă sta pomembnejša pritoka Donave Valea Mare in Peştera. Vodotoki imajo nihajoč pretok in so večino leta prehodni tudi zunaj mostov. Izjema sta kanal Donava-Črno morje in

${ }^{10}$ O učinkih reliefa na premik in manever vozil glej podrobneje v: Bratun, 1998, str. 67.

" Glej sliko 1 v prilogi.

12 Glej sliko 2 v prilogi.

${ }_{13}$ Zračni tokovi poganjajo številne vetrnice za pridobivanje električne energije predvsem v zaledju rta Kaliakra. Glej sliko 2 v prilogi.

${ }^{14}$ V starejši literaturi najdemo bolgarski izraz Medžižija.

${ }^{15}$ Lagune in jezera, ki imajo na stiku z morjem nasipe peska in mivke, so poimenovani v geografski literaturi za območje Črnega morja z izrazom limani. 
Grafa 1 in 2:

Razporeditev in

količina padavin

ter temperatura

za Dobrič

Vir:

http://www.

worldweathe-

ronline.com/

Dobric-weather averages/

Dobrich/BG. aspx
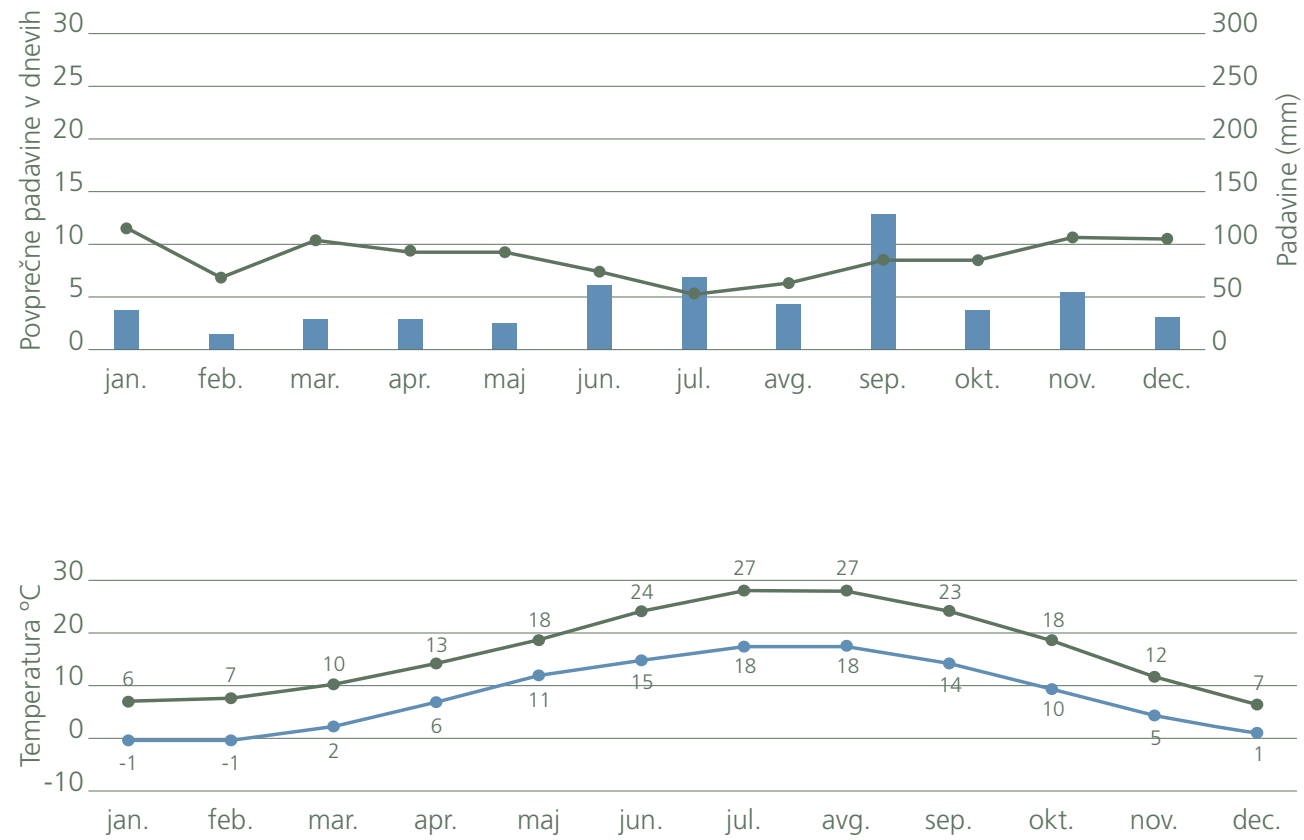

sistem limanov na severozahodu, ki prehajajo v močvirno delto Donave. Posledica take hidrografske mreže, kraških vodotokov, erozijskih jarkov in kanaliziranosti dolin je zgostitev ugodnih prečnih prehodov čez Dobrudžo po dolini Cernavodă-Constanca in vzdolžnih po uravnavi med mestoma Medgidia in Dobrič.

\section{RAZVOJ PROSTORSKIH STRUKTUR}

Osrednji del Dobrudže je agrarna kulturna krajina, v kateri so prvotne izstopajoče reliefne oblike odstranili, zravnali, zaoblili naklone in meliorirali površje. Tako so površje prilagodili masovni uporabi kmetijske mehanizacije ${ }^{16}$. Zaobljene površine so danes obsežni kmetijski kompleksi. Prehodnost in preglednost teh kompleksov ovirajo pasovi zaraslih gozdnih mej med sklenjenimi območji kmetijskih površin in vzdolž cest. Slednje poleg ločevalne funkcije zmanjšujejo učinke vetra in eolsko erozijo. Industrijski kompleksi so se razvili v obmorskem delu. Izstopajo pristanišča Varna, Mangalia in Constanca. Ob Donavi sta razviti industrijski središči ter rečni pristanišči Silistra in Tulcea. V osrednjem delu Dobrudže se je industrija razvila V mestih Medgidia in Dobrič.

${ }_{16}$ Tovrstni agromelioracijski posegi so bili še posebno izraziti v romunskem delu Dobrudže v 70. in 80. letih prejšnjega stoletja. Tak je primer pokrajine okoli kraja Amzacea (bolgarsko Amzača), kjer kljub podrobnemu opisu pokrajine, Kladivarji, 1936, str. 271-273, ni bilo mogoče najti območja spopadov leta 1916, saj opisan videz reliefnih oblik (aprila 2014) zaradi poznejšega preoblikovanja ni bil prepoznaven (Bratun, 2005, Dnevnik potovanj). 
Zaradi intenzivnega kmetovanja in ugodnih podnebnih razmer je razvita predelovalna industrija. Obilje gradbenih surovin, kot so prod in mivka iz strug rokavov Donave, apnenec, lapor ter glina, je omogočilo razvoj industrije cementa in opekarn, zato pomembno mesto zavzema gradbeništvo. Ladjedelništvo v Varni in Constanci se krči zaradi nekonkurenčnosti in zastarele tehnologije. Povečuje se pomen turizma V obmorskih letoviščih. Po vstopu Romunije in Bolgarije v Evropsko unijo se je okrepil transport. Iz prejšnjih obdobij je ostal v Dobrudži del elektroindustrije, tekstilne in nekaj težke industrije. Celotna Dobrudža je energetsko odvisna. Elektrocentrale so le na akumulacijskem jezeru na reki Suha in na pretočnih pregradah kanala pri kraju Cernavodă in mestu Medgidia. Naftnih polj in črpališč plina ni. Energetski potencial je v vetrni energiji vzdolž obale Črnega morja in solarni energiji zaradi dobre osončenosti regije.

Geoprometne razmere v Dobrudži so dobre. Cestno omrežje zaradi razmeroma ugodnih reliefnih razmer povezuje vse kraje. Pomen železniških povezav se je zaradi preusmeritve transporta na ceste zmanjšal. Kljub temu železniške proge povezujejo vsa pomembnejša mesta v Dobrudži s preostalimi predeli v Bolgariji in Romuniji. Najpomembnejša geoprometna os Dobrudže ostajajo kana $1{ }^{17}$ in vzporedno potekajoča elektrificirana železniška proga ter avtocestna povezava med krajem Cernavodă in Constanco. Čezmejne povezave so osredotočene na mednarodna pristanišča ob Črnem morju in Donavo.

\section{BOJI NA VZHODNI FRONTI, VZROKI ZA SPOPADE V DOBRUDŽI LETA 1916}

Na vzhodni fronti so si ob začetku nasproti stale šibkejše oborožene sile kot na zahodni fronti. Tako naj bi proti Rusiji glavno breme nosila avstro-ogrska vojska. Rusi so kljub začetni pobudi avgusta 1914 doživeli hud poraz pri Tannebergu. Večji uspeh so dosegli proti avstro-ogrski vojski, ko je ta pod vodstvom Conrada von Hötzendorfa z ofenzivo želela dopolniti nemške uspehe z ofenzivo na reki Visli 23. 8. 1914, toda enote generala Brusilova so jih zadržale in jim zlasti v Galiciji zadale velike izgube, okoli 900.000 vojakov $^{18}$. Posebej znamenite so bile bitki pri Lvovu avgusta in septembra 1914 ter bitka pri Ravi Ruski. Fronta se je ustalila na obrobju Karpatov do aprila 1915, ko so Avstrijci začeli znova prodirati z juga. Po začetnih

\footnotetext{
${ }^{17}$ Kanal je dolg 64,2 kilometra in skrajšuje plovbo po Donavi za okoli 400 kilometrov glede na plovno pot Črno morje-Izmail-Tulcea-Cernavodă. Glavna pomanjkljivost kanala je v omejeni globini ugreza za ladje (do 5000 bruto registrskih ton) glede na reko Donavo, po kateri plujejo ladje z nosilnostjo do 25.000 bruto registrskih ton (Klemenčić, 1997, str. 432-433).

${ }^{18}$ Prav v tem času, 16. 5. 1916, je bil sklenjen tajni sporazum med zavezniškimi državami, tako imenovani sporazum Sykes-Picot o delitvi Otomanskega cesarstva po končanju vojne.V skladu s sporazumom bi Velika Britanija pridobila nadzor nad območjem današnjega Izraela, Jordanije in Iraka ter večjim delom območja ob Perzijskem zalivu. Francija bi dobila nadzor na območju današnjega Libanona, Sirije, severnega Iraka in jugovzhodne Turčije. Rusija bi tako dobila območje Istanbula, morskih ožin Bosporja in Dardanel ter armenski del Otomanskega cesarstva. Za Rusijo bi neoviran dostop v Egejsko morje in do Soluna omogočil edinstveno geopolitično pozicijo na postbizantinskem območju, kar bi pospešilo neizogiben razpad Otomanskega cesarstva v obliki, ki ne bi bila pod nadzorom Zahoda. Grčija bi lahko postala del ruske geopolitične orbite, oblikovale bi se velike slovanske pravoslavne države z restavriranim verskim središčem v Konstantinoplu (po Naročnicka, 2011, str. 79-89; http://www. militaryhistoryonline.com/wwi/articles/ romania duringwwi.aspx).
} 
bojih so jih Rusi ustavili. Več uspeha so imele nemške enote na severu, ko so rusko armado potisnile skoraj za 500 kilometrov nazaj. Centralne sile so v tej ofenzivi od maja do decembra 1915 tako v bitkah pri Tarnovu in Gorlicah osvojile Galicijo in Bukovino, Rusi pa so se morali umakniti iz Poljske in Litve. Fronta se je ustalila na črti od Černovic na jugu prek Pinska in Baranowicza do Rige na severu. Zajetih je bilo okoli 300.000 ruskih vojakov in 3000 topov, zaradi slabega položaja v ruski vojski je poveljstvo prevzel ruski car Nikolaj II. Zaradi teh uspehov so Nemci napotili rezerve na zahodno fronto v boje pri Verdunu. Ruski general Brusilov je z ofenzivo do oktobra 1916 avstro-ogrsko vojsko potisnil daleč nazaj v Volinijo in Galicijo. Zajel je okoli 70.000 vojnih ujetnikov in pošteno načel moralo centralnih sil (Naročnicka, 2005; Nećak, 2005; Tomac, 1973; Willmott, 2008).

Romunija se je od začetka vojne pogajala z obema vojskujočima se stranema za vstop v vojno in hkrati čakala na razplet dogodkov, predvsem na vzhodni fronti $^{19}$. Odločilnega pomena so bile Brusilova ofenziva ${ }^{20}$ in obljube Antante, da bodo Romuniji po vojni pripadali Transilvanija ter deli Banata in Bukovine (Stone, 1998; Tomac, 1973; Nećak, 2005; Vojna enciklopedija, 9. zvezek, 1967; http://www.militaryhistoryonline.com/wwi/articles/).

Z vstopom Romunije ${ }^{21}$ se je vzhodna fronta podaljšala za okoli 500 kilometrov, vse do Črnega morja. Vloga Romunije v zavezništvu je bila vojaško udejstvovanje v Transilvaniji, od koder bi se ofenziva podaljšala proti Budimpešti in Banatu. Njena Tretja armada bi sprejela sprva obrambne naloge do prihoda ruskih enot v Dobrudžo z zavezniško Vzhodno armado z juga oziroma iz Soluna, obkolila Bolgarijo in jo izločila iz vojne ${ }^{22}$. Centralne sile so podpisale konvencijo, v kateri so za vojno proti Romuniji predvidevale udejstvovanje glavnih sil iz Transilvanije prek mesta Sibiu. Pomožne sile bi vpadle v Dobrudžo iz Bolgarije, zavzele mostišči pri krajih Tutrakan in Silistri, z globokim prodorom ogrozile zaledje romunske vojske in

19 Septembra 1914 sta ruski zunanji minister Sazanov in njegov romunski kolega Daimandy podpisala tajni sporazum med državama, s katerim se je Rusija obvezala k obrambi romunske ozemeljske celovitosti in priznala romunske ozemeljske zahteve proti Avstro-Ogrski. Romunija pa se je obvezala ostati nevtralna (http://www. militaryhistoryonline.com/wwi/articles/romania duringwwi.aspx).

${ }^{20}$ Druga (septembra in oktobra 1916) in tretja (od oktobra do decembra 1916) ofenziva Brusilova ter četrta ofenziva Brusilova in Kerenskega niso bile uspešne. K temu so pripomogle demoralizacija ruske vojske in težave z oskrbo, zato se je začela vojna sreča na vzhodu obračati na nemško stran. Julija 1917 so centralne sile pridobile nazaj vso Galicijo in Bukovino, septembra 1917 so zavzeli tudi Rigo in oktobra 1917 otoke Ösel, Dag in Moon. Eden izmed vzrokov za vstop Romunije v vojno na strani Antante je bila tudi 6. soška bitka oziroma italijansko zavzetje Gorice (po Nećak, 2005, str. 118).

${ }^{21}$ Pred začetkom operacij je imela romunska vojska štiri armade: 23 pehotnih divizij, dve konjeniški diviziji in pet konjeniških brigad, 1300 topov, skupaj s teritorialnimi enotami in zaledjem pa okoli 813.000 pripadnikov oboroženih sil. Opremljenost vojske je bila zastarela, primanjkovalo je težkega topništva, streliva in konj, nerazvita železniška struktura je oteževala oskrbo in podporo, primanjkovalo je tudi častniškega kadra (Vojna enciklopedija, 9. zvezek, 1967, str. 386).

${ }^{22}$ Po sporazumu med Francijo, Rusijo in Romunijo se je slednja obvezala, da bo branila Dobrudžo in reko Donavo pred morebitnim napadom Bolgarije. Hkrati je Francija pričakovala, da bo vstop Romunije v vojno zmanjšal pritisk Nemčije na zahodni fronti, zato je še pred prihodom ruskih oboroženih sil v Dobrudžo 28. 8. 1916 napovedala vojno Avstro-Ogrski. Naslednji dan je Romuniji napovedala vojno Nemčija, 30. 8. 1916 Turčija in 1. 9. 1916 še Bolgarija (http://www. firstworldwar.com/source/romania_wollman.htm). 
prekinile stik z ruskimi enotami. V severni Bolgariji ${ }^{23}$ je bila oblikovana armadna skupina pod poveljstvom nemškega generala Mackensena. Njegov cilj je bil prodreti v Dobrudžo pred prihodom ruskih enot, premagati romunske enote in se z delom armadne skupine ob ustju Donave pripraviti na obrambo. Preostali del bi prečkal Donavo pri Svištovu in proti Bukarešti sodeloval z nemško 9. armado, ki bi prodirala iz Transilvanije. Pred začetkom spopada je bila ob spodnji Donavi in v Dobrudži razporejena vzhodna skupina romunske 3 . armade ${ }^{24}$. Ruski 47. korpus (61. pehotna in 3. konjeniška divizija) ter 1. srbska dobrovoljska divizija sta bila nastanjena ob rusko-romunski meji pri Reniju (Vojna enciklopedija, 1959; Vojna enciklopedija, 1967; Stone, 1998).

\section{PROSTOVOLJSKO GIBANJE LETA 1916 IN FORMIRANJE ENOT PROSTOVOLJCEV}

Prostovoljsko gibanje med Slovenci je v Rusiji sprva nastalo iz spontane akcije avstro-ogrskih Jugoslovanov, ki so padli v rusko ujetništvo in vzpostavili stik ${ }^{25}$ s srbskim veleposlaništvom v Petrogradu. Toda prostovoljsko gibanje je sprva naletelo na oviro, saj se carska Rusija ni takoj odločila za zbiranje prostovoljcev zaradi prepovedi mednarodnega vojnega prava o uporabi zajetih vojakov proti lastni državi; prav tako so se bali represalij nemških in avstro-ogrskih oblasti proti ruskim ujetnikom. Kljub temu so srbski predstavniki v Rusiji dosegli, da so bili iz ujetništva izpuščeni tisti »Jugoslovani«, ki so se prijavili kot prostovoljci.

Januarja 1916je ruski car Nikolaj II. odobril formiranje vojaških enot iz prostovoljcev, ujetnikov avstro-ogrske vojske. Tako so srbski predstavniki v začetku leta 1916 načrtno obiskovali ruska ujetniška taborišča, v katerih so bili Srbi, Hrvati in Slovenci kot zajeti pripadniki avstro-ogrske vojske. Zagotavljali so jim, da se bodo bojevali za svobodo svoje domovine v okvirih skupne jugoslovanske države. Zaradi pritiska Rusije in Jugoslovanskega odbora ${ }^{26}$ je Srbija začela organizirano ustanavljati prostovoljske enote iz prebeglih oziroma ujetih avstro-ogrskih vojakov slovanskega porekla. Te enote naj bi pozneje premestili na solunsko fronto, da bi sodelovale pri osvoboditvi Srbije.

\footnotetext{
${ }^{23}$ Glavnino je predstavljala bolgarska 3. armada (1. sofjiska divizija, koncentrirana pri Isperihu-Kemanlarju, 4. preslavska divizija pri Kubratu-Balbunarju, deli 6. bdinske divizije severno od Novega Pazarja do Jerd Pazarja, 1. konjeniška divizija severno od Brestaka-Kara Agač, Varnski odred severno od Varne, posadka Ruse-Ruščnk in nemški odred Kaufmann proti Tutrakanu; pozneje naj bi se vključile še dve turški diviziji in nemška brigada Bode.

${ }^{24}$ 17. divizija na mostišč u pri Tutrakanu, 9. divizija pri Silistru, 19. divizija v okraju Dobrič in 5. konjeniška brigada pri Balčiku. Ruski 47. korpus (ruska 61. pehotna in 3. konjeniška divizija) ter 1. srbska dobrovoljska divizija so bili nastanjeni ob rusko-romunski meji pri Reniju.

${ }_{25}^{25}$ To je že leta 1915 prejelo okoli 10.000 prošenj z zahtevami po izpustitvi iz ujetništva in dovoljenjem za vstop v srbsko vojsko.

${ }^{26}$ Jugoslovanski odbor, ki so ga sestavljali predvsem politični emigranti iz Avstro-Ogrske, je bil ustanovljen 30. aprila 1915 v Londonu.
} 
Prva četa, iz katere je pozneje nastala prostovoljska divizija, je nastala iz enote »dobrovoljcev « ${ }^{27}$, ki je varovala skladišče srbske delegacije v Odesi, ki je kupovala žito v južni Rusiji za srbske enote. Decembra 1915 je bilo v tej četi že 200 vojakov in 7 častnikov. V tem času so začeli izdajati tudi svoj časopis Slovenski Jug, ki je širil propagando med Jugoslovani, vojnimi ujetniki, in dodatno pripomogel k vse večjemu odzivu prostovoljcev, ki so se zbirali okoli srbske delegacije v Odesi. Nastal je odred. Zaradi vse te množice prišlekov so voditelji prostovoljskega gibanja prosili vlado kraljevine Srbije, da izvede vojaško organizacijo nad prostovoljci (Turk, 1936; Turk, 1978; Švajncer, 1998, Sekulić, 2010; Slovenska novejša zgodovina 1).

V tem času se je zaradi velikega dotoka prostovoljcev srbska vlada odločila za formiranje še ene dobrovoljske divizije, zato je bil 26. 7. 1916 formiran Srbski dobrovoljski korpus ${ }^{28}$, ki sta ga sestavljali 1. in 2. srbska dobrovoljska divizija. Zaradi bojev 1. srbske dobrovoljske divizije v Dobrudži in velikih potreb po nadomeščanju izgub se je formiranje 2. srbske dobrovoljske divizije zavleklo za vsaj pol leta. Do 20. 11. 1916 je imela 2. srbska dobrovoljska divizija že dobrih $11.000 \mathrm{mož}^{29}$.

Aprila 1916 so prispeli srbski višji častniki s Krfa pod vodstvom polkovnika Stevana Hadžića in začeli uriti prostovoljce. Maja 1916 so jih obiskali predsednik srbske vlade Nikola Pašić, ruski general Brusilov in ruski car Nikolaj II. Junija 1916 je bila v Odesi uradno ustanovljena 1. srbska prostovoljska divizija ${ }^{30}$, ki je bila organizirana po ruskem vzoru ${ }^{31}$. Štela je 555 častnikov ter 18.457 podčastnikov in vojakov. V drugem polku so bili vsi častniki prvega bataljona Hrvati, razen enega Slovenca in enega Srba; drugi bataljon je imel večinoma slovenske častnike z enim Srbom in enim Hrvatom; tretji bataljon pa tako srbsko večino in po enega Hrvata oziroma Slovenca med častniki (Turk, 1978; Dobrovoljci kladivarji Jugoslavije, 1936). Carska Rusija je tudi priskrbela orožje ${ }^{32}$.

\footnotetext{
${ }^{27}$ Izraz dobrovoljec je starinski izraz za prostovoljec in ga v besedilu uporabljam zaradi prepisa originalnega izrazoslovja $v$ uporabljenih virih in literaturi.

${ }^{28}$ Njegov poveljnik je bil general Živković. Pozneje je korpus sestavljal še polk Matije Gubca v Tomsku v Sibiriji (Sekulić, 2010).

29 Od tega je bilo 6200 Srbov, 3144 Hrvatov, 1556 Slovencev, osem Poljakov, 13 Malorusov in 84 vojakov preostalih narodnosti. 2. srbsko dobrovoljsko divizijo so formirali iz dopolnilnega bataljona in (ne) prostovoljcev, ki so jih nabrali med oktobrsko (nasilno) mobilizacijo, zato jih je veliko želelo nazaj v ujetništvo ali v rusko vojsko. Tako so novembra 1916 ustanovili tako imenovano vzgojno šolo, v kateri so častniki prostovoljci predavali prostovoljcem o jugoslovanskem vprašanju in pomenu oboroženega boja proti AvstroOgrski za osvoboditev in združitev jugoslovanskih narodov (Grašič, 1984).

${ }^{30}$ Glej sliko 3 v prilogi; Postroj častnikov 1. srbske dobrovoljske divizije in obisk carja Nikolaja II., junij 1916 (Ratni album 1914-1918).

${ }^{31}$ Imela je dve prostovoljski brigadi (vsaka s po dvema polkoma), gorski topniški oddelek, konjeniški divizijski oddelek, vod za oskrbo in oddelek za zveze.

${ }_{32}$ Dobili so majhno število poljskih topov, z različnih bojišč nabrane avstrijske puške na en naboj ter zarjavele strojnice, sestavljene iz različnih modelov (Turk, 1936; Dobrovoljci kladivarji Jugoslavije, 1936). Poleg tega je Rusija imela v prvih dveh letih vojne težave s proizvodnjo pušk, ki ni zadostila potrebam na frontah. Tako so morali orožje uvoziti iz držav zaveznic, kar pa je na terenu povzročilo logistične težave, saj so enote imele v uporabi kar deset različnih pušk (Willmott, 2008). Oblečeni so bili v ruske uniforme in srbsko »šajkačo«.
} 


\section{BOJI (SLOVENSKIH) PROSTOVOLJCEV V DOBRUDŽl ${ }^{33}$}

Ko je Romunija pristopila na stran zavezništva Antante, se je rusko vrhovno poveljstvo sporazumno s srbsko vlado odločilo, da se srbska prostovoljska divizija skupaj z ruskimi in romunskimi enotami uporabi za bojne operacije v Dobrudži. Skupaj z rusko pehotno in konjeniško divizijo je sestavljala 47. korpus ruske armade in bila pod ruskim vrhovnim poveljstvom generala Zajončkovskega.

Junija 1916 je 1. srbska dobrovoljska divizija zasedla območje med Belgarodom in Renijem $^{34} \mathrm{v}$ jugozahodnem delu Besarabije. Avgusta tega leta je divizija nadaljevala pot na vlačilcih po Donavi do mesta Cernavodă in se nato zbirala v Medgidiji. Kljub protestu poveljnika divizije, polkovnika Hadžića, zaradi pomanjkanja topništva in tehničnih čet, je morala divizija oditi na fronto. Njeno operativno območje je bilo jugozahodni del Dobrudže vzdolž železniške proge med mestom Constanca in bolgarskim obmorskim mestom Varna (Turk, Dobrovoljci kladivarji Jugoslavije, 1936).

Mackensenove enote so prečkale mejo v noči z 31. 8. na 1. 9. 1916. Varnski odred in deli 6. divizije so v bojih proti romunski 19. armadi 4. 9. 1916 zavzeli Dobrič. Nemška 1. konjeniška divizija je presekala povezavo med Dobričem in Silistro, 6. 9. 1916 so 1. sofijska in 4. preslavska divizija z nemškim odredom Kaufmann zasedli Tutrakan, zajeli večji del romunske 17. divizije in ustavili napad romunske 15. divizije, ki je poskušala $z$ leve obale Donave osvoboditi Tutrakan. Medtem je na območje Dobriča prispel 47. ruski korpus, ki je 5. 9. 2014 z 61. pehotno divizijo in romunsko 19. divizijo napadel bolgarski Varnski odred in dele 6. divizije, da jih potisne z Dobriča. 7. 9. 1916 se je v boje vmešala tudi 1. srbska dobrovoljska divizija, ki je s svojima 3. in 4. polkom razbila 36. polk bolgarske 6. divizije pri Osmanfakiju, medtem ko je bil napad ruske 61. in romunske 19. divizije severno od Dobriča odvrnjen. Istega dne so se deli bolgarske 1. konjeniške divizije in 2. bataljona 16. lovskega polka zapletli v boje s 4. polkom srbske dobrovoljske divizije, ki je s težkim bojem odbil bolgarski napad. 1. srbska dobrovoljska divizija se je zaradi razbitosti po celi fronti umaknila na začetni položaj, zaradi neuspeha in velikih izgub so se v noči s 7. na 8. 9. 1916 vse sile Vzhodne skupine in 47. ruskega korpusa umaknile na črto Oltina Jezero-Mangalija, kjer so vse romunske sile prešle pod neposredno poveljstvo ruskega generala Zajončkovskega. Te sile so bile t. i. Dobrudžanska armada (Turk, 1936; Dobrovoljci kladivarji Jugoslavije, 1936, Vojna enciklopedija 1959).

Mackensenove enote so po prerazporeditvi in popolnitvi 13. 9. 1916 spet začele z ofenzivo: 6. divizija, 1. konjeniška divizija in Varnski odred so napadli odsek romunske 19. in ruske 61. pehotne divizije; 4. preslavska divizija je napadla odsek 1. srbske dobrovoljske divizije, 1. sofijska divizija pa romunsko 9. divizijo. Prostovoljska divizija je zadala 1. sofijski in 4. preslavski diviziji hud udarec pri

\footnotetext{
${ }_{33}$ V prilogi je shema večjih bojev 1. srbske dobrovoljske divizije leta 1916.

${ }^{34}$ Glej sliko 4: Prostovoljci na ladjah in vlačilcih na Donavi pri kraju Reni, poleti 1916 (Ratni album 1914-1918).
} 
Tekederesiju, saj ju je čelno napadla in tako preprečila napad na rusko in romunsko divizijo na desnem oziroma levem krilu. Ob tem je zaplenila pet poljskih topov, več mitraljezov, pušk, streliva in prehrambnih zalog. Najbolj je bil zaslužen 2. polk dobrovoljske divizije, ki ga je obiskal sam general Zajončkovski in se jim s priklonom zahvalil za to junaško dejanje (Kladivarji, 247).

Zaradi uspehov Varnskega odreda in delov 6. bolgarske divizije proti ruski 61. pehotni diviziji in 3. ruski konjeniški diviziji ter nevarnosti pred zajetjem obeh kril se je Dobrudžanska armada v noči na 15. 9. 1916 umaknila na črto Rašova-KobadinTuzla $^{35}$. Kljub uspehom pri Dobriču in Tekederesiju se je 1. srbska dobrovoljska divizija morala umakniti nazaj na to črto, da se izravna, saj se je pri odseku romunske armade že močno pomaknila proti severu (Turk, 1936; Dobrovoljci kladivarji Jugoslavije, 1936, Vojna enciklopedija, 1959).

Po bojih pri Tekederesiju so se Mackensenove enote ${ }^{36}$ približale položajem enot Zajončkovskega in jih napadle 18. 9. 1916 na celi fronti. Tega dne je nemško brigado Bode zadržala romunska 9. divizija, medtem ko je 1. srbska dobrovoljska divizija odbila napad 1. in 4. bolgarske divizije. Dopoldne so Bolgari ob podpori artilerijskega ognja ponovno napadli 1. srbsko dobrovoljsko divizijo in jo potisnili južno od Idris Kujusa. Bolgari so z ogromno premočjo 28 bataljonov in 96 poljskih topov napadli 12-kilometrski odsek fronte, ki ga je branilo le devet bataljonov s prostovoljsko divizijo vred, ki pa je bila močno oslabljena od prejšnjih spopadov in je še kar čakala na popolnitev svojih razredčenih vrst. Še posebej se je tukaj pokazala pomanjkljiva oborožitev prostovoljskih enot, ki so uporabljale puške brez okvirjev in niso imele večjih možnosti proti bolgarskim »repetirkam«, zato je bil v prvi fazi umik neizbežen, in to kar pet kilometrov severno od prej omenjene utrjene črte.

Naslednji dan, 19. 9. 1916, so 1. srbska dobrovoljska divizija, 9. romunska divizija, ruski 242. polk in romunska 10 . brigada s protinapadom razbili bolgarski 7 . polk in potisnili nazaj 16., 25., 31. polk in del 41. polka ter zavzeli Bujuk Mezarlik Bajra pri Kokardži. Tako je srbska prostovoljska divizija porazila velik del bolgarske 3. armade in jo prisilila v umik in ustavitev prodiranja za skoraj mesec dni. Prostovoljska divizija je $\mathrm{v}$ teh treh dneh po nekaterih podatkih izgubila kar 24 častnikov in 256 vojakov, ranjenih je bilo 96 častnikov in 3258 vojakov, pogrešanih 464 vojakov; skupaj so torej izgubile 120 častnikov in 3970 vojakov, iz bojev pa je bilo izločenih kar 4090 mož (Kladivarji, 263; Pavlović, Pešić, 2006).

\footnotetext{
${ }_{35}$ To črto je Romunija utrdila že ob začetku vojne, če bi prišlo do spopada z Bolgarijo, in bi preprečila prodiranje skozi Dobrudžo ter ogrožanje pomembne prometne povezave Črno morje-Cernavodă-Bukarešta (Kladivarji, 252).

${ }^{36}$ Cilj nemške armade pod vodstvom maršala Mackensena in bolgarske armade pod vodstvom generala Toševa je bil s hitrim napadom presenetiti 3. romunsko armado in ji tako onemogočiti utrditev na postojankah, ki so jih zasedli. Po porazu romunske vojske so nameravali pospešiti ofenzivo v Dobrudži in zasesti železniško progo Cernavodă-Costanca. S tem so nameravali zaključiti bojne operacije v Dobrudži in usmeriti vojaški stroj $v$ severno Bolgarijo.Tam bi se začela ofenziva prek Donave proti Bukarešti, vendar so jim zavezniške enote prekrižale načrte. Zaradi velikih izgub so se enote generala Mackensena umaknile na položaje Enidža-Sofular, kjer so se okrepile s 6. turškim korpusom, nemško 217. divizijo in štirimi eksadriljami.
} 
20. in 21. 9. 1916 je prostovoljska divizija ostala še na utrjenih položajih nad Kokardžo, ko so jo 22. 9. 1916 zamenjale romunske enote in se divizija umakne v armadno rezervo v Mamut Cuius, kjer je bila popolnjena s 16 častniki in 1890 vojaki, ki so prišli iz dopolnilnega bataljona v Odesi (Kladivarji, 263; Pavlović, Pešić, 2006).

Po bitki pri Kokardži so boji za nekaj časa ponehali, vendar je prostovoljska divizija že 2. 10. 1916 dobila ukaz za napad nasprotnika pri Amzači ${ }^{37}$. Dobrudžanska vojska generala Zajončkovskega je napadla centralne sile in zavzela Amzačo, da bi tako olajšali 3. romunski diviziji prehod Donave pri Flamandu v severni Bolgariji. Srditi boji so se razvili v okrajih Engez in Amzača, vendar se zaradi poraza romunske 1. armade Zajončkovskega 6. 10. 1916 umaknejo na obrambne položaje. Ko se je tako Mackensen osvobodil pritiska 3. romunske divizije v ozadju, je z močno artilerijsko podporo 19. 10. 1916 krenil v napad, in sicer z vzhodno skupino ${ }^{38}$ na odseku Amzača-Donava. Boji so se začeli 19. 10. 1916 z močnim napadom bolgarske pehote ob močni podpori topništva Zborne divizije. Strelski rovi prostovoljske divizije so bili tako zasuti z ogromnimi količinami zemlje. V teh težkih razmerah so se prostovoljci dobro držali in uspelo jim je celo ustaviti Bolgare pred rovi. Ti so se podnevi poskušali prebiti na levem krilu, vendar je bil z močnim ognjem tudi ta poskus zaustavljen. Na desnem krilu je bila romunska 19. divizija, na katero so Nemci načrtovali odločen napad, kar je pripeljajo do tega, da so se romunske enote začele umikati in zapuščati rove. Tako je ostalo krilo prostovoljske divizije nezaščiteno in izpostavljeno močnemu bočnemu ognju, zato je poveljnik ukazal umik na rezervni položaj na greben Balabanara. Prostovoljska divizija se je umaknila v območje Osmanfaka in vzpostavila zvezo z rusko 61. divizijo in na levem krilu z romunskimi enotami.

Tako je ob umiku dobrudžanske armade 1. konjeniška divizija bolgarske vojske prodrla v ozadje romunskih 9. in 19. divizije ter 22. 10. 1916 zavzela Constanzo. Zajončkovski je poskušal še z dodatno prispelima 3. strelsko in 9. sibirsko divizijo upočasniti Mackensena, ki pa je kljub temu 23. 10. 1916 zavzel Medžižijo in se 25. 10. 1916 ustavil na liniji Boadžik-jezero Tašau. Dobrudžanska armada se je ustavila na liniji Topalo-severno od Tašaua.

Boji so se nadaljevali vse do 26. 10. 1916, vendar brez večjega uspeha, prav tako so ostali brez hrane, saj se je intendantska enota že umaknila daleč v ozadje. V teh okoliščinah je poveljnik divizije polkovnik Hadžić dobil ukaz, da se divizija umakne v Isakči ob spodnji Donavi in zavaruje tamkajšnje mostišče. Poveljniki polkov divizije so zaprosili poveljstvo generala Zajončkovskega za preklic ukaza, saj so bile enote divizije popolnoma izčrpane in zdesetkane. Poveljnik Hadžić se je postavil na stran svojih častnikov, zato je poveljstvo kljub negodovanju ugodilo zahtevam in divizija se je po dveh mesecih in pol umaknila na zasluženi počitek v Odeso. V teh bojih so

\footnotetext{
${ }^{37}$ Glej sliko 5 v prilogi: Spomenik padlim v mestu Amzača.

${ }^{38}$ Vzhodno skupino so sestavljale bolgarska Zborna divizija, trije polki 6. divizije in dva dopolnilna polka, 1. konjeniška in nemška 217. divizija.
} 
padli trije častniki in 125 vojakov, ranjenih je bilo 44 častnikov in 791 vojakov ter pogrešanih 472 vojakov; iz boja izločenih je bilo 1435 mož (Pavlović, Pešić, 2006). 1. srbska dobrovoljska divizija po 26. 10. 1916 ni bila več v neposrednem stiku s Centralnimi silami in je bila napotena v Izmail v sestav Dobrovoljskega korpusa Srbov, Hrvatov in Slovencev.

Tabela 1: 1. srbska dobrovoljska divizija v večjih spopadih proti Centralnim silam leta1916*

\begin{tabular}{|c|c|c|}
\hline Datum & Kraj/Smer & Rezultat \\
\hline $\begin{array}{l}\text { Junij-avgust } \\
1916\end{array}$ & Medgidia & Zbirališče divizije pred začetkom spopadov. \\
\hline 7. 9. 1916 & Dobrič/Osmanfaki & 3. in 4. bataljon divizije razbijeta bolgarski 36. polk 6. divizije. \\
\hline 8. 9. 1916 & Oltina Jezero-Mangalija & $\begin{array}{l}\text { Umik celotnega ruskega } 47 \text {. korpusa zaradi izgub in } \\
\text { razbitosti }\end{array}$ \\
\hline 13. 9.1916 & Tekederesi (Valca Tapului) & $\begin{array}{l}\text { Divizija zada hud udarec 1. sofijski in 4. preslavski diviziji } \\
\text { ter tako prepreči napad na rusko in romunsko divizijo, dobi } \\
\text { osebno pohvalo generala 47. ruskega korpusa. }\end{array}$ \\
\hline 15. 9.1916 & Rašova-Kobadin-Tuzla & $\begin{array}{l}\text { Umik na to frontno črto zaradi strnitve enot 47. ruskega } \\
\text { korpusa }\end{array}$ \\
\hline 18. 9.1916 & Idris Cuius & $\begin{array}{l}\text { Divizija sprva odbije napad 1. in 4. bolgarske divizije, vendar } \\
\text { se zaradi bolgarske premoči umakne z drugimi enotami } \\
\text { korpusa } 5 \text { km severno od utrjene frontne črte. }\end{array}$ \\
\hline 19. 9. 1916 & Kokardža & $\begin{array}{l}\text { 1. srbska dobrovoljska divizija je skupaj z romunskima } \\
\text { divizijama porazila velik del 3. bolgarske armade in jo ustavila } \\
\text { za skoraj mesec dni. }\end{array}$ \\
\hline 22. 9. 1916 & Mamut Cuius & 1. srbska dobrovoljska divizija se umakne v armadno rezervo. \\
\hline $\begin{array}{l}\text { 2.-19. } 10 . \\
1916\end{array}$ & Amzača-Engez & $\begin{array}{l}\text { Umik celotne dobrudžanske armade zaradi bolgarske in } \\
\text { nemške premoči. 1. dobrovoljska divizija se umakne na } \\
\text { območje Asmanfaka. }\end{array}$ \\
\hline 26. 10. 1916 & Isakča-Odesa & $\begin{array}{l}\text { Poveljnik 1. srbske divizije zavrne ukaz za zavarovanje } \\
\text { mostišča pri Isakči zaradi izčrpanosti divizije. Divizija se } \\
\text { umakne v Odeso. }\end{array}$ \\
\hline
\end{tabular}

*Kraji so prikazani v Shemi bojev 1. srbske dobrovoljske divizije leta 1916. 


\section{USIHANJE PROSTOVOLJSKEGA GIBANJA PO SPOPADIH V DOBRUDŽl}

Med bojevanjem 1. srbske dobrovoljske divizije v Dobrudži so na pobudo Jugoslovanskega odbora začeli ustanavljati Srbski dobrovoljski korpus, ki je bil 16. 9. 1916 ustanovljen samo iz poveljstva in nekaj štabnih enot. Zaradi slabšega odziva prostovoljcev ${ }^{39}$ so odredili prisilno mobilizacijo med avstro-ogrskimi vojaki, ki so bili v ruskem ujetništvu. Tako so v Odeso pripeljali okoli 9000 Hrvatov in okoli 4000 Slovencev, kar je povzročilo odpor in ustanovitev tako imenovanega disidentskega gibanja z močno podporo avstro-ogrske obveščevalne službe.

Skupina hrvaških in slovenskih častnikov, ki so marca 1917 poslali poveljniku dobrovoljskega korpusa peticijo, s katero so zahtevali, da se ime Srbski dobrovoljski korpus spremeni v Jugoslovanski dobrovoljski korpus. Zahtevali so tudi zamenjavo srbskih emblemov in oznak za jugoslovanske, da se slovenski in hrvaški vojaki razporedijo $\mathrm{v}$ homogene narodnostne enote, ki jim bodo poveljevali slovenski oziroma hrvaški častniki, da se prostovoljci pravno štejejo kot vojaki prihodnje Kraljevine Jugoslavije, da se enot prostovoljcev ne sme uporabljati za bojne naloge zunaj domovine oziroma meja prihodnje Jugoslavije in za gmotno in finančno izenačenje s pripadniki redne srbske vojske. Nezadovoljstvo, ki je sprožilo odpor, je številne vojake in častnike spodbudilo k izstopu iz enote. Po februarski revoluciji so ti zahtevali pravno in materialno ureditev svojih statusnih vprašanj in da se korpus ne šteje kot srbska vojska, temveč kot jugoslovanska revolucionarna vojska. Tako je srbska vojska dovolila v enotah ustanovitev vojaških svetov in divizijo preimenovala v 1. prostovoljsko divizijo Srbov, Hrvatov in Slovencev, vendar kljub temu ni uspelo preprečiti spomladi 1.1917 izstop približno 150 častnikov in 12.735 vojakov. Med disidenti je bilo 42 slovenskih častnikov in 1241 vojakov; korpus je še vedno štel približno 30.000 vojakov $^{40}$. Razmere so se delno uredile šele po odhodu glavnine korpusa (okoli 24.000 vojakov) na solunsko fronto avgusta 1917 (Sekulić, 2010; Slovenska novejša zgodovina 1, 2005).

1. srbska dobrovoljska divizija je 27. 9. 1917 dobila ukaz za premik na solunsko fronto v smeri Odesa-Arhangelsk-Francija-Solun. Ob odhodu je štela 13.066 vojakov, med katerimi je bilo tudi 86 slovenskih vojakov. Po prihodu v Solun je divizija imela le še 2545 vojakov in 158 častnikov ${ }^{41}$.

\footnotetext{
${ }^{39}$ Poraz 1. srbske dobrovoljske divizije je slabo vplival tudi na nadaljnji razvoj prostovoljskega gibanja v Rusiji. Številni so zapuščali prostovoljska zbirališča, prehajali na rusko stran, nekateri nekdanji ujetniki pa so se vračali v avstro-ogrsko vojsko. Vpliv je imela tudi okrepljena propagandna in obveščevalna dejavnost avstroogrske vojske na fronti in $v$ domačih krajih, ki je podpirala tudi disidente.

40 To je bil močan udarec za prostovoljsko gibanje, saj je samo 2. srbsko dobrovoljsko divizijo zapustilo 45 odstotkov vojakov in častnikov, celotni srbski dobrovoljski korpus pa 40 odstotkov. Disidentom se je sredi leta 1917 pridružilo 3787 slovenskih dobrovoljcev, med njimi 42 slovenskih častnikov.

${ }^{41}$ Od aprila 1917 do maja 1918 so iz Rusije na solunsko fronto prepeljali 640 častnikov in 12.500 podčastnikov in vojakov. Že od junija 1916 pa je bilo v srbski vojski na solunski fronti 3380 dobrovoljcev, do aprila 1918 pa je iz obeh Amerik prišlo okoli 4000 dobrovoljcev izseljencev in iz Italije okoli 300. Po podatkih Milisava Sekulića je pri preboju solunske fronte in osvoboditvi Srbije sodelovalo skupno 20.180 dobrovoljcev, od tega vsaj 194 Slovencev.
} 
Vzroke za takšen osip je mogoče iskati v velikih izgubah v Dobrudži, disidentskem gibanju in splošnih razmerah v Rusiji. V srbski vojski je bilo identificiranih 567 slovenskih prostovoljcev, od teh jih je padlo 42, največ ravno v Dobrudži, in sicer 14, enako število tudi na solunski fronti (Sekulič, 2010).

Prostovoljci so pokazali izjemen pogum in požrtvovalnost, vendar rezultati niso bili dobri, saj zaradi pomanjkljive izurjenosti zavezniških romunskih enot in tudi slabše vojaške opreme niso bili kos številčnejšim in bolje opremljenim enotam Centralnih sil.

Težave so bile tudi znotraj divizije, saj je bila večina častniškega kadra srbske narodnosti, ki niso bili navajeni na nesrbske podčastnike. Povelja so prihajala v treh jezikih: ruskem, romunskem in celo v francoskem. Večina nižjih častnikov in podčastnikov pa je razumela le nemška povelja in znake. Operativno je bila divizija del 47. ruskega korpusa, ki pa je bil podrejen romunski armadi, zato ni bilo enotnih operativnih načrtov in taktičnih ciljev. Velike težave so pomenili tudi pomanjkljiva opremljenost, zastarelo orožje (puške brez okvirjev), zaradi slabe oskrbe pa so bili prostovoljci velikokrat tudi po več dni lačni. Zaradi pomanjkanja topništva in konjenice, ki ju divizija ni imela, je bila manevrsko omejena (Sekulič, 2010).

\section{POMEN PROSTOVOLSKEGA GIBANJA V DOBRUDŽI}

Krvni davek prostovoljske divizije ${ }^{42}$ in s tem tudi slovenskih prostovoljcev ni bil zaman, saj je bolgarski armadi prizadejal usoden poraz, ki je prišel do izraza šele v bitki za Kajmakčalan na solunski fronti, ko so demoralizirane bolgarske enote utrpele velike izgube. Slovenski prostovoljci so bili med prvimi v srbski vojski, in to v okoliščinah, ko so jih najbolj potrebovali. Njihovo število presega povprečje drugih narodov v srbski vojski, posebej izstopa tudi izobrazbena oziroma intelektualna struktura, saj je bilo med njimi veliko zdravnikov, aktivnih častnikov, pravnikov, profesorjev, novinarjev, književnikov itn. Iz seznama dobrovoljcev (Sekulić, 2010) je razvidno veliko priimkov, ki so se pojavljali oziroma se še danes pojavljajo visoko v slovenskem družbenopolitičnem prostoru.

Prostovoljci so bili v celotnem 47. ruskem korpusu poznani kot pogumni, požrtvovalni in disciplinirani vojaki, podčastniki in častniki. Deset izmed njih jih je dobilo tudi najvišje srbsko kraljevo priznanje - Karadžordževo zvezdo z meči ${ }^{43}$. To tudi danes potrjuje neko povezanost, ko pripadniki Slovenske vojske dobro sodelujejo na mirovnih misijah po svetu in so zelo dobro sprejeti tudi med lokalnim prebivalstvom.

Nekateri zgodovinarji menijo, da bi prostovoljce morali uvrstiti med slovenske vojne veterane. Politični pomen skupnega boja slovenskih prostovoljcev v srbskih enotah je pokazal velesilam jasno željo po odpravi avstro-ogrske nadoblasti in združitvi v samostojno državo.

\footnotetext{
${ }_{42}$ Glej sliko 6 v prilogi, Spomenik - piramida na pokopališču v mestu Medgidia (avtor Z. Bratun, april 2014).

${ }^{43}$ Podatek velja za prostovoljce v vseh srbskih osvobodilnih vojnah (Sekulić, 2010).
} 


\section{SODOBNE GEOPOLITIČNE, GEOSTRATEŠKE IN VOJAŠKOGEOGRAFSKE POTEZE DOBRUDŽE}

Sodobne geopolitične razmere v Dobrudži so zaznamovane s pogostimi menjavami meje med Romunijo in Bolgarijo in nasilnimi preselitvami prebivalstva v preteklosti. Pestra je nacionalna struktura prebivalstva. Po letu 1878 je Dobrudža prešla izpod turške pod romunsko in bolgarsko oblast. Ena izmed posledic II. balkanske vojne je bila priključitev južne Dobrudže Romuniji. V posesti Romunije je Južna Dobrudža ostala do sporazuma v Craiovi leta 1940. Tedaj sta se Romunija in Bolgarija pod patronatom Nemčije dogovorili o priključitvi Južne Dobrudže k ozemlju Bolgarije. Navedena meja je bila potrjena s Pariško mirovno konferenco leta 1947 (Klemenčić, 1997, str. 127), po tem pa se meja ni več spreminjala. Obe državi sta bili članici Varšavskega pakta do njegove razpustitve. V tem obdobju je imela Bolgarija vlogo trojanskega konja na Balkanu. Pristanišče Varna je bilo glavna logistična baza in izhodišče za krepitev navzočnosti enot Rdeče armade v zaledju Dobrudže (Faringdon, 1989, str. 127).

Po padcih komunističnih režimov v Romuniji in Bolgariji sta se obe državi pospešeno prilagajali spremembam ter izpolnjevanju zahtev za vključitev v Nato in Evropsko unijo. Od leta 2007 sta Romunija in Bolgarija članici Evropske unije. Na njunih zunanjih mejah je vzpostavljen šengenski mejni režim. Carinskih kontrol na mejah ni več. Nadzor meje je skupen ${ }^{44}$. Mejni pas severnega dela Dobrudže je poseljen z Romuni ${ }^{45}$.

$\mathrm{V}$ povezavi s spreminjanjem mejne črte so tesno povezane številne selitve prebivalstva. Južna Dobrudža je danes večinsko poseljena z Bolgari. Spremembe v narodnostni strukturi Dobrudže so prikazane v tabeli 2.

Pomembne geostrateške poteze Dobrudže so povezane s položajem ob obali Črnega morja, plovni poti po Donavi, prehranskim dejavnikom in nadzorom ilegalnih migracij.

Geografski položaj Dobrudže ob jugozahodni obali Črnega morja omogoča nadzor plovnih poti in plutja ladij do pristanišč Varna, Mangalia in Constanca. Bolgarija in Romunija v sodelovanju s Turčijo v tem delu nadzirajo promet po Črnem morju. Romuni nadzorujejo rečni promet v spodjem delu in delti Donave ${ }^{46}$. Dobrudža je ugodneje kopensko in pomorsko povezana z Bolgarijo. Geostrateško pomanjkljivost

\footnotetext{
${ }^{44}$ Zaznana je bila neenakopravna delitev mejnih opravil. Na mejnem prehodu Yovkovo so 22. 4. 2014 zunaj delali pripadniki bolgarskih mejnih organov. Romunski mejni policisti so med tem sedeli v kabinah in nadzirali delo (Bratun, 2005, Dnevnik potovanj).

${ }^{45}$ Sporazumevanje s prebivalci tega dela Dobrudže ob iskanju zapuščin prve svetovne vojne je bilo naporno. Angleško niso znali, razen treh oseb v mestu Mangalia. Bolgarsko ali rusko niso znali ali niso hoteli razumeti. Predvsem starejši so se raje obrnili stran ali preslišali vprašanje in odšli (Bratun, 2005, Dnevnik potovanj).

${ }^{46}$ Del tega nadzora si zaradi priključitve Besarabije Sovjetski zvezi danes lasti Ukrajina. Ob glavnem toku Donave je večje pristaniško mesto Izmail, od koder je mogoč nadzor rečnega prometa. To dejstvo je pospešilo romunsko odločitev za gradnjo kanala med Cernovodo in Constanco. Kanal je bil zgrajen leta 1983. Zaradi krajše plovne poti in bližine geoprometnih prostorskih struktur je večina ladijskega transporta z Donave v Črno morje in obratno zgoščena prav na ta kanal. Zaradi višinskih zapornic je plovba nekoliko počasnejša.
} 
Tabela 2:

Severna Dobrudža

Pregled narodnostne strukture $v$ Dobrudži ${ }^{77}$

\begin{tabular}{|c|c|c|c|}
\hline Narodnost & $1913^{[1]}$ & $1930^{[2]}$ & $2002^{[3]}$ \\
\hline Romuni & $216.425(56,8 \%)$ & $282.844(64,7 \%)$ & $883.620(90,9 \%)$ \\
\hline Bolgari & $51.149(13,4 \%)$ & $42.070 \quad(9,6 \%)$ & $135(0,01 \%)$ \\
\hline Turki & $20.092 \quad(5,3 \%)$ & $21.748 \quad(5 \%)$ & $27.580 \quad(2,8 \%)$ \\
\hline Tatari & $21.350 \quad(5,6 \%)$ & $15.546 \quad(3,6 \%)$ & $23.409 \quad(2,4 \%)$ \\
\hline Rusi-Lipovanci & & $26.210 \quad(6 \%)$ & $21.623(2,2 \%)$ \\
\hline Rutenci & & $33(0,01 \%)$ & $1.465 \quad(0,1 \%)$ \\
\hline Nemci & $7.697 \quad(2 \%)$ & $12.023(2,75 \%)$ & $398(0,04 \%)$ \\
\hline Grki & $9.999 \quad(2,6 \%)$ & $7.743 \quad(1,8 \%)$ & $2.270(0,23 \%)$ \\
\hline Romi & $3.263 \quad(0,9 \%)$ & $3.831 \quad(0,88 \%)$ & $8.295(0,85 \%)$ \\
\hline Vsi & 380.430 & 437.131 & 971.643 \\
\hline
\end{tabular}

Južna Dobrudža*

\begin{tabular}{|l|r|r|r|}
\hline Narodnost & 1910 & $1930^{*}[2]$ & \multicolumn{1}{|c|}{$2001^{[4]}$} \\
\hline Bolgari & $134.355(47,6 \%)$ & $143.209(37,9 \%)$ & $248.382(69,5 \%)$ \\
\hline Turki & $106.568(37,8 \%)$ & $129.025(34,1 \%)$ & $76.992(21,6 \%)$ \\
\hline Romi & $12.192(4,3 \%)$ & $7.615(2 \%)$ & $25.127(7 \%)$ \\
\hline Tatari & $11.718(4,2 \%)$ & $6.546(1,7 \%)$ & $4515(1,3 \%)$ \\
\hline Romuni & $6.348(2,3 \%)$ & $77.728(20,5 \%)$ & $591(0,2 \%)$ \\
\hline Vsi & 282.007 & 378.344 & 357.217 \\
\hline
\end{tabular}

* Med letoma 1926 in 1938 je ta del Dobrudže pripadal Romuniji.

Severne Dobrudže predstavlja ločenost ozemlja od preostalega dela Romunije zaradi struge Donave. Povezave z osrednjim delom Romunije so omejene na mostove čez Donavo pri kraju Cernavodă in v bližini kraja Hărşova. Južna Dobrudža je pokrajinsko zlita s preostalim ozemljem Bolgarije. To ji omogoča nemotene geoprometne povezave proti jugozahodu in osrednjemu Balkanu ter Trakiji. ${ }^{47}$

\footnotetext{
${ }^{47}$ Vir: http://en.wikipedia.org/wiki/Dobruja\#mediaviewer/

Podatki so povzeti po:

${ }^{[1]}$ Roman, IN (1919). »La population de la Dobrogea. D'apres le recensement du 1 er janvier 1913«. In Demetrescu, A. La Dobrogea Roumaine. Études et documents (in French). Bucarest. OCLC80634772.

${ }^{[2]}$ Calculated from results of the 1930 census per county, taken from Mănuilă, Sabin (1939). La Population de la Dobroudja (in French). Bucarest: Institut Central de Statistique. OCLC1983592.

${ }^{[3]}$ Calculated from statistics for the counties of Tulcea and Constanța from »Populația după etnie la recensămintele din perioada 1930-2002, pe judete« (PDF) (in Romanian). Guvernul României - Agenţia Națională pentru Romi. pp. 5-6, 13-14. Retrieved 2007-05-02.

${ }^{[1]}$ Calculated from the results of the 2001 Bulgarian census for the administrative regions of Dobrich and Silistra, from »Население към 01.03.2001 г. по области и етническа група« (in Bulgarian). Националния статистически институт. Retrieved 2007-05-02.
} 
Celotna Dobrudža je kmetijsko razvita regija. Še zlasti za zahodno Dobrudžo velja, da je žitnica Bolgarije. Prehranska samozadostnost in viški kmetijskih pridelkov v povezavi s klimatskimi pogoji omogočajo ugodno logistično oskrbo. Po vključitvi Bolgarije in Romunije v Evropsko unijo je območje Dobrudže postalo privlačno za migrante. Bližina turške vzhodne obale in kopenska povezava Bolgarije z Grčijo ter Romunije z Madžarsko pomenijo mogoče koridorje ilegalnim migrantom na poti v Srednjo in Zahodno Evropo. Pristanišča omogočajo prikrit pretovor in transport prepovedanih snovi v preostale dele Evrope (http://rrgp.uoradea.ro/art/2010-2/19 RRGP-183-Nicoara+Urdea.pdf).

Dobrudža je vojaškogeografsko umeščena $\mathrm{v}$ operativno raven ${ }^{48}$. Njena lega in velikost sta pomembni za koncentracijo vojaških sil in mostišče v črnomorskem bazenu. Vojaškogeografski položaj Dobrudže je zaznamovan s članstvom Bolgarije in Romunije v Natu.

Pomembne vojaškogegrafske točke Dobrudže in njenega obrobja so vojaške baze Varna $^{49}$, Kaliakra, Mangalia, Constanca in Medgidia. V Varni sta osrednja vojaška pomorska baza Bolgarije in letališče. Na rtu Kaliakra je telekomunikacijska vojaška postojanka, s katere nadzirajo in spremljajo pomorski promet med Bosporjem in pristanišči na obalah Črnega morja. Mangalia je sedež pomorskih enot Romunije. Kopenske enote so razmeščene v vojašnicah v kraju Medgidia in Constanci ${ }^{50}$. Letalska baza je pri letališču Constanca.

Nerešena mejna vprašanja zaradi priključitve Besarabije k Ukrajini in spori o lastništvu Kačjega otoka zaznamujejo pomen Severne Dobrudže.

Zaradi nove geopolitične in ekonomske situacije se je pojavila težnja po zavarovanju zunanje meje Evropske unije, tako na Donavi, na meji z Ukrajino in morski obali. Romunija in Bolgarija sta povečali obmejne policijske in carinske enote. Ta intenzivnejša obmejna kontrola bi lahko $\mathrm{v}$ prihodnosti povzročila napetosti med Romunijo in Ukrajino (http://rrgp.uoradea.ro/art/2010-2/19_RRGP-183Nicoara+Urdea.pdf).

Hkrati je Dobrudža primerna za razmestitev večjih vojaških enot. To omogočajo učinkovite in obsežne prometnice, zmogljivosti pristanišč za pretovor blaga in ljudi, prostori za namestitev vojaških baz in reka Donava z delto kot naravna pregrada proti severovzhodu na meji z Moldavijo in Ukrajino. Hkrati je Dobrudža tudi operativno izhodišče za posege zaradi odprtosti in bližine obal ter pristanišč Črnega morja proti severovzhodu (Odesa, Herson, Sevastopol, Soči in Batumi).

\footnotetext{
${ }^{48}$ Umestitev in vojaškogeografska raven območja sta povzeti po metodologiji v Bratun; 1997, str. 8, in Brinkerhof; 1993, str. 1056.

${ }^{49}$ Čeprav je Varna zunaj ozemlja Dobrudže, jo zaradi bližine in razvitih vojaških prostorskih struktur umeščam v ta sklop.

50 Tu ima sedež 9. mehanizirana brigada (Vienna document 2011; str. 7, pridobljen v Verifikacijskem centru Slovenske vojske, Ljubljana, november 2014).
} 
Zaradi naštetih dejstev je ozemlje Dobrudže ob širitvi konfliktov v operativnem območju med Kavkazom, Kaspijskim morjem in Dnjeprom pomorsko in kopensko koncentracijsko območje za vojaške sile Nata.

Sklep Dobrudža je geografska regija na jugovzhodu Evrope, ki ima pomembne vojaškogeografske, geostrateške in geopolitične poteze. Bližina kriznih žarišč, občasna mednacionalna trenja na širšem območju Podonavja, zgodovinska dediščina in geoprometne lastnosti določajo sodobni pomen te regije. Naravne značilnosti ustvarjajo pogoje za intenzivno kmetijstvo, gradbeništvo in razvoj prometnih prostorskih struktur. Njena obmorska lega omogoča nadzor znatnega dela Črnega morja in pretovor blaga ter storitev za vzhodni del Evropske unije.

V prvi svetovni vojni je bila Dobrudža bojišče operativnih razsežnosti. Slovenski prostovoljci v 1. srbski dobrovoljski diviziji oziroma Srbskem dobrovoljskem korpusu so v bojih na vzhodnih bojiščih Dobrudže pokazali izjemen pogum in požrtvovalnost, vendar rezultati niso bili zadovoljivi, saj zaradi slabše vojaške opreme niso bili kos številčnejšim in bolje opremljenim enotam Centralnih sil. Težave so bile tudi znotraj divizije, saj se je zaradi nezadovoljstva slovenskih in hrvaških dobrovoljcev pojavilo tako imenovano disidentsko gibanje, ki je zahtevalo enakopravnost s srbskimi vojaki in preimenovanje divizije $\mathrm{v}$ jugoslovansko dobrovoljsko divizijo oziroma jugoslovanski korpus.

Sodobne geopolitične in geostrateške poteze območja so posledice nasilnih spreminjanj meja. Poseben pomen ima Dobrudža zaradi neurejenih razmer $\mathrm{v}$ Pridnestru, spremenjenega vojaškogeografskega položaja v Črnem morju po priključitvi Krima k Rusiji in konfliktov v operativnem prostoru med Kavkazom, Kaspijskim morjem in Dnjeprom.

1. Bratun, Z., 2005, Vojaška geografija I. Ljubljana: Založba Maklen, Fakulteta za družbene vede.

2. Faringdon, H., 1989. Strategic Geography. London, New York: Routledge.

3. Grant, R. G., 2014. 1. svetovna vojna. Ljubljana: Mladinska knjiga Založba.

4. Naročnicka, N., 2011. Ruski narod v bitki civilizacij. Ljubljana: UMco.

5. Nečak, R., 2005. Prelom 1914-1918. Ljubljana: Sophia.

6. Stone, N., 1998. The Eastern Front. London: Penguin books.

7. Turk, E., 1978. Dobrovoljci proti Avstro-Ogrski: med prvo svetovno vojno 1914-1918, Ljubljana: Borec.

\section{Zborniki}

8. Fischer, J., ur., 2005: Slovenska novejša zgodovina 1. Ljubljana: Mladinska knjiga Založba.

9. Klemenčić, M., ur., 1997. Atlas Europe. Zagreb: Leksikografski zavod Miroslav Krleža.

10. Popović, A., ur., 1926. Ratni album 1914-1918. Beograd: Uredništvo Ratnog albuma.

11. Šiljegović, B., ur., 1959. Vojna enciklopedija. Beograd: Redakcija vojne enciklopedije.

12. Šljegović, B., ur., 1967. Vojna enciklopedija. Beograd: Redakcija vojne enciklopedije. 
13. Švajncer, J. J., 1998. Vojna zgodovina. Ljubljana: DZS.

14. Tomac, P., 1973. Prvi svetski rat 1914-1918. Beograd: Vojnoizdavački zavod.

15. Turk, Ernest, ur., 1936. Dobrovoljci kladivarji Jugoslavije, 1912-1918. Ljubljana; Maribor: samozaložba Sreskih organizacij Saveza ratnih dobrovoljaca Kraljevine Jugoslavije.

16. Willmott, H.P., 2008. First world war. Great Britain: Dorling Kindersley.

\section{Članki}

17. Brinkerhof, R. J., 1993. Geography, Military; V T. Dupuy. International Military and Defense Encyclopedia. New Jersey: Macmillan, str. 1055-1062.

18. Grašič, M., 1984. Oris vprašanja jugoslovanskih vojnih dobrovoljcev v času prve svetovne vojne v Rusiji in pojav disidentskega gibanja. VJ. Koropec, ur. C̆asopis za zgodovino in narodopisje. Maribor: Založba Obzorja, številka 2, str. 310-333.

19. Ilešić, S., 1939. Iz današnje Dobrudže. V S. Bajič, ur. Misel in delo. Ljubljana: Nasta, letnik $V$, številka 8-9, str. 259-264.

20. Stanev, N., 1939. Bolgarija in Dobrudža. V S. Bajič, ur. Misel in delo. Ljubljana: Nasta, letnik V, številka 8-9, str. 264-269.

21. Sekulić, M., 2010. Slovenski dobrovoljci v srbskih osvobodilnih vojnah 1912-1918. VM. Kranjc, ur. Vojaška zgodovina. Ljubljana: Ministrstvo za obrambo, številka 1 (17), letnik 11/2010, str. 7-55.

22. Turk, E., 1936. Ob dvajsetletnici bojev 1. dobrovoljske divizije v Dobrudži. V Misel in delo. Ljubljana: Nasta, letnik II, številka 9-10, str. 285-293.

\section{Disertacije}

23. Bratun, Z., 1997: Geografski dejavniki državnovarnostnega sistema Republike Slovenije, Disertacija. Filozofska fakulteta, Univerza v Ljubljani.

Internetni viri

24. Adochitei, L., 2014. Romania and its allies during World War I. http://www.militaryhistoryonline.com/wwi/articles/romaniaduringwwi.aspx, 20. 11. 2014.

25. Pavlović, Pešić, 2006a. Junaci sa Dobrudže. http://www.novosti.rs/dodatni_sadrzaj/clanci.119.html:277691, 22. 11. 2014.

26. Pavlović, Pešić, 2006b. Poraz Romuna. http://admin.novosti.ha.rs/dodatni_sadrzaj/ clanci.119.html:277693, 22. 11. 2014.

27. Pregled narodnostne strukture v Dobrudži. http://en.wikipedia.org/wiki/Dobruja, 22. 11. 2014.

28. Zemljevid Dobrudža, http://en.wikipedia.org/wiki/Dobruja\#mediaviewer/File:Dobrudja topographic_mapen.svg, 22. 11. 2014.

29. Dobric. Monthly Climate Average, Bulgaria. http://www.worldweatheronline.com/Dobricweather-averages/Dobrich/BG.aspx, 24. 11. 2014.

30. Dobruja. An European cross border Region.

http://rrgp.uoradea.ro/art/2010-2/19_RRGP-183-Nicoara+Urdea.pdf, 24. 11. 2014.

Drugo

31. Bratun, Z.: Dnevnik potovanj od 2005 dalje, lastni pisni vir. Šmarje - Sap.

32. Department of the Army, 1994, Intelligence preparation of the battlefield - FM $34-130$, Headquarters, Department of the Army, Ministry of Defense, Washington DC.

33. Vienna Document 2011, na podlagi prvega poglavja Annual exchange of military information, členi od 9. do 14.4 (pridobljen v verifikacijskem centru Slovenske vojske, Ljubljana 2014). 


\title{
"MARKET GARDEN« - THE EPIC AND THE TRAGEDY OF ALLIED PARATROOPERS IN THE NETHERLANDS
}

\author{
»MARKET GARDEN« - \\ JUNAŠTVO IN TRAGEDIJA ZAVEZNIŠKIH \\ PADALSKIH ENOT NA NIZOZEMSKEM
}

Abstract Operation "Market Garden" is an allied military operation fought in the Netherlands and Germany in the Second World War, considered by certain military specialists as the biggest, most daring and most dramatic allied airborne operation during the war. This article highlights two phases of this operation: the "Market" (air) phase, which employed fighters, bombers, transport aircraft and gliders with the objective of seizing and securing the bridges in the targeted area, and the "Garden" (ground) phase of the operation, which was intended to allow the ground troops, supported by tanks and infantry, to cross the Netherlands at highest speed, occupy a bridgehead across the Rhine and enter Germany.

The author details all the steps of the Battle (17-25 September 1944), mentioning the early successes, the logistic shortcomings, the strong controversies among the most important allied military leaders, the landings, the advances and the German reactions, also pointing out the role played by the Polish Parachute Brigade, commanded by Major General Stanislaw Sosabowski.

To conclude, he enumerates the main reasons for the indisputable failure of this Operation, not leaving aside a conspiracy theory belonging to French historian Jacques de Launay.

Key words

Allied airborne operation, phase operations; air landings, General B. L. Montgomery, General George S. Patton, Polish Parachute Brigade.

Povzetek Operacija Market Garden je bila zavezniška vojaška operacija na Nizozemskem in v Nemčiji med drugo svetovno vojno. Po mnenju vojaških strokovnjakov je bila to največja, najbolj drzna in najbolj dramatična zavezniška zračnodesantna operacija v drugi svetovni vojni.

V članku sta opisani dve fazi te operacije: (zračna) Market, v kateri so sodelovala lovska letala, bombniki, transportna ter jadralna letala, ki so imela cilj zaseči in zavarovati mostove na ciljnem območju, in (kopenska) Garden, katere namen je bil 
kopenskim enotam ob podpori tankov in pehote omogočiti, da čim hitreje prečkajo Nizozemsko, zasedejo mostišče čez reko Ren ter vstopijo v Nemčijo.

Avtor natančno opiše vse korake te bitke, ki je potekala od 17. do 25. septembra 1944, ter pri tem izpostavi začetne uspehe, logistične pomanjkljivosti, huda nasprotja med najpomembnejšimi voditelji zavezniških vojsk, pristanke, napredovanje in nemške odzive, opozori pa tudi na vlogo, ki jo je v operaciji imela poljska padalska brigada pod poveljstvom generalmajorja Stanislawa Sosabowskiga.

V sklepu našteje glavne razloge za neuspeh te operacije, pri čemer ne izpusti niti teorije zarote, ki jo zagovarja francoski zgodovinar Jacques de Launay.

\section{Ključne} besede

\section{Zavezniška zračnodesantna operacija, fazne operacije, jadralnoletalsko delovanje, general B. L. Montgomery, general George S. Patton, poljska padalska brigada.}

Introduction The (airborne) parachute troops, developed as a result of the new perspectives that the aviation provided to the spectacular growth of the speed of manoeuvre by transporting troops by air, by completely eliminating the servitudes of the terrestrial communications, and by creating excellent conditions for achieving surprise, attracted a special interest in the period before the Second World War. Their creation and development represents, in fact, the recognition of the virtues of a service that could be deployed quickly and at great distances, over obstacles and improper terrains sometimes totally inaccessible to other services. Surprising the enemy thus became a major advantage, causing considerable losses to the enemy, with important and, why not, even decisive consequences for the development and outcome of military actions in progress.

As the specialists have widely appreciated, the Second World War in the twentieth century was the largest deployment of human forces that fought for over six years on the ground, in the air, as well as on and under the sea.

The outstanding achievements in the field of weapons, ammunition, combat equipment and materials from units and large units, which naturally produced major changes in the military art of belligerents, undeniably marked the progress of war.

In the theatres of military actions of the Second World War, the Germans and the Japanese, followed shortly by the Soviets, the British and the Americans, courageously addressed certain new types of operations that military theorists had imagined in the interwar period. Air, air-naval, air-ground-naval and air-ground operations provided the ones who invested in the new types of forces and means with rapid and sweeping successes on the fronts in Europe, Asia, North Africa and the Pacific.

Thus, the airborne troops affirmed and enhanced themselves within the wide range of military structures in the years of the Second World War, being present in different numbers, from one state to another, depending, first of all, on the capacity to provide the means of air lift. Starting from the operation "Weserübung", launched by the 
German army in the spring of 1940, in order to conquer Denmark and Norway, and until August 1945, when the Soviet troops landed in the Far East, the actions of airborne troops took place in the theatres of military operations at tactical, operational and strategic level. Renowned for their spectacular and bold actions, resulting in impressive, resonant victories, beneficial for all military operations, airborne operations also resulted in failures, which triggered political decisions about the future of these forces.

Unlike the extraordinary development of German airborne troops in the period preceding the war, the Anglo-American troops were developed with great restraint and evolved slowly, but surely and effectively, the German experience in the field being further refined. The operations of allied airborne troops culminated in 1944, in June and September.

The successes gained in previous operations had granted the airborne troops with a posture which, it was believed, suggested their widespread use.

Largely dependent upon the synchronisation of actions of the three components of the battle space (land, air and sea), the success of airborne operations was often uncertain, because the land forces with which they would interconnect failed to fulfil their missions in due time. Hence, the engagement and retaining of airborne troops in actions that exceeded their combat power and strength. The case of the $1^{\text {st }}$ British Airborne Division in Arnherm is, as we shall see, conclusive in this regard.

Operation “Market Garden” in September 1944 was considered by military experts to be the biggest, boldest and most dramatic allied airborne operation of the Second World War (Sainte-Croix, 1978, p. 107) and, at the same time, the last major operation of allied airborne troops in Europe. Yet, "Market Garden" was a failure because of the ambitions of certain vain commanders, and, why not, because of the superficiality in planning operations and a series of wrong decisions, resulting in the unnecessary death of thousands of paratroopers, many of them participants in wellprepared operations launched under what seemed to be successful circumstances.

\section{PRELIMINARY CALCULATIONS}

After the Normandy landings (Operation Overlord, June 1944) and the opening of a second allied front in Europe, the allied terrestrial offensive did not go as easily as the allies would have wanted it, because the Germans put up fierce resistance. The hardships encountered in providing adequate logistic support to the entire allied front required the focusing of the effort on certain directions, which caused strong controversy among allied military leaders (General B. L. Montgomery, Commander of the $21^{\text {st }}$ Army Group, in the North, and General George S. Patton, Commander of the US Third Army, in the South), who each wanted that the main attack and the crossing of the Rhine would take place through the sector of the troops they commanded. 
It was believed that the success in Normandy credited the airborne troops with a status that required their extensive use. After being sent to Great Britain to recover, in early August 1944, the First Allied Airborne Army was activated, consisting of US $13^{\text {th }}, 17^{\text {th }}, 82^{\text {nd }}$ and $101^{\text {st }}$ Airborne Divisions, British $1^{\text {st }}$ Airborne and $6^{\text {th }}$ Parachute Divisions and a Polish $1^{\text {st }}$ Parachute Brigade, the US $9^{\text {th }}$ Troop Carrier Command and Royal Air Force troop carrier units. This great and powerful structure was commanded by American General Lewis H. Brereton who, even though was not a specialist in the use of airborne troops, had great experience in air operations.

Although many airborne operations were planned, most of them were cancelled because the actions on the ground proved many times to be more efficient and less costly in this offensive against the clock towards Berlin.

\section{EXAGGERATED OPTIMISM AND MISTAKEN HYPOTHESES}

The threat posed by the Germans, who could massively launch their new V-2 rockets, as well as the desire to keep the German army under pressure, can be considered among the causes that led to the outbreak of Operation "Market Garden", although the conditions for success were not met basically. Moreover, the range of action of allied transport aircraft, for which airfields in Europe had not been built yet and which therefore had to take off from Great Britain, required that the operation should be prematurely launched. In the atmosphere of optimism that reigned at the Allied Headquarters, it was estimated that the war would end by winter and this would be the last opportunity to highlight the role of airborne troops (Ryan, 1977, pp. 118-119).

This time, same as in Normandy, the allies relied on the element of surprise and on the striking power of the airborne troops which, conquering the bridges over Meuse and Rhine by rapid action, would be immediately supported by the armoured troops that would move quickly on the lines of communication in the region. As we shall see, this premise proved to be wrong, starting right from the fact that the German army was not as weak as the allies would wish it to be.

\section{FORCES, MEANS, MISSIONS, GOALS}

American General Dwight D. Eisenhower, Supreme Commander of the Allied Forces in Europe, assigned the $21^{\text {st }}$ Allied Army Group, US 81 ${ }^{\text {st }}$ and $101^{\text {st }}$ Airborne Divisions, British $1^{\text {st }}$ Airborne Division and Polish Parachute Brigade for this operation, employing a total of 35,000 people, 5,000 aircraft and 1,500 gliders. British General Bernard Law Montgomery, who established the concept of the operation, made the $21^{\text {st }}$ Army Group in charge with the mission to initiate the offensive on the line along the Albert canal, in the direction of Eindhoven, Arnhem and, in cooperation with the air landing launched in the districts of Eindhoven, Nijmegen, in order to seize the crossings over the Meuse and Rhine, free the Netherlands and turn the fortified line "Siegfried" through the north. 
Figure 1: Map of Operation Market-Garden

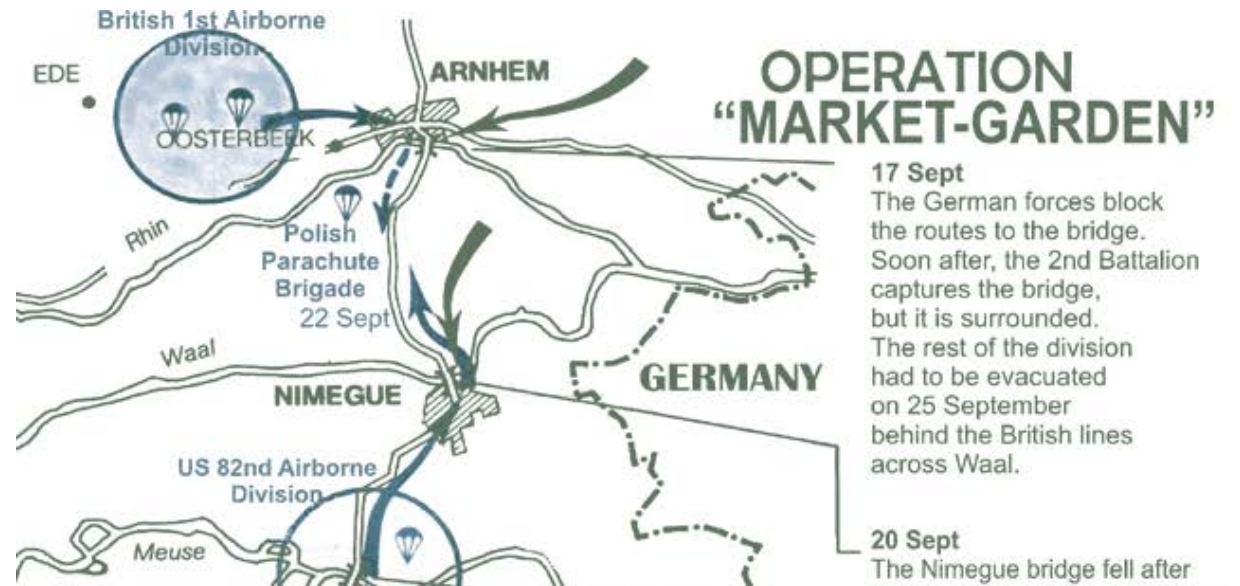

The Nimegue bridge fell after a combined American Parachute Battalion and British 30th Corps attack

17 September, in the afternoon

The bridge is captured.

The British 30 th Corps

makes contact with the paratroopers on 19 September, at 08:20.

\section{Sept}

All bridges are captured. The British 30 th Corps makes contact with paratroopers on 18 September, in the afternoon.
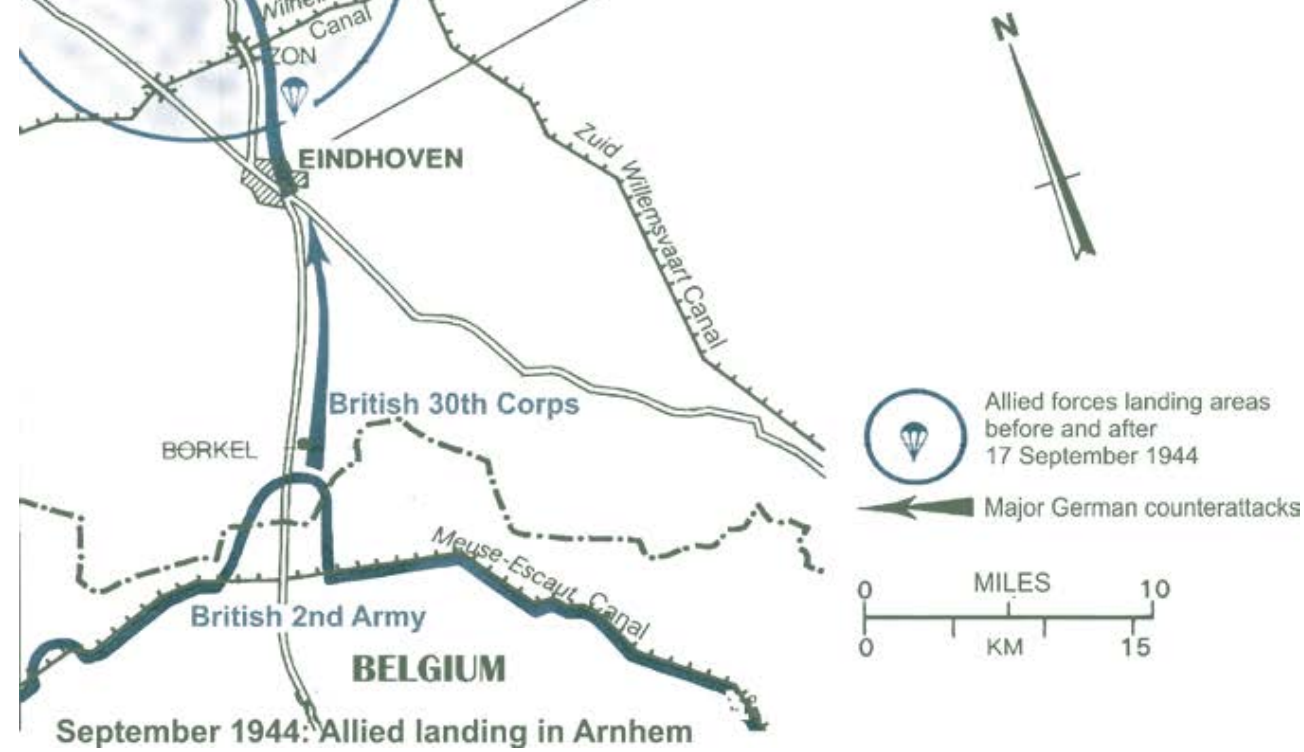
The "Market" (air) phase of the operation stipulated the use of nearly 5,000 fighters, bombers and transport aircraft and over 2,500 gliders. US $101^{\text {st }}$ Airborne Division (General Maxwell D. Taylor), with 501 $502^{\text {st }}$ and $506^{\text {th }}$ Parachute Infantry Regiments, was to be launched north of Eindhoven and to conquer the bridges over the canal and the river, from Son and Veghel, in a sector of $24 \mathrm{~km}$ between Eindhoven and Veghel. The American 82 $2^{\text {nd }}$ Airborne Division (General James M. Gavin), with $504^{\text {th }}, 505^{\text {th }}$ and $508^{\text {th }}$ Parachute Infantry Regiments, had to reach the area between Grave and Nijmegen, in a sector of $16 \mathrm{~km}$, and to conquer the bridges over the rivers Maas and Waal and the 800-metre long bridge in Nijmegen. The British $1^{\text {st }}$ Airborne Division (General Robert "Roy” E. Urquhart), with $1^{\text {st }}$ Airborne Brigade (General Philip “Pip” Hicks), $1^{\text {st }}$ Parachute Brigade (General Gerald Lathbury) and $4^{\text {th }}$ Parachute Brigade (General John “Shan” Hackett) and the Polish $1^{\text {st }}$ Independent Parachute Brigade (General Stanislaw Sosabowski) were assigned with the most difficult part of the job, namely to take action in the northern extreme of the front, near Arnhem, where the road bridge across the lower Rhine was, having a width over $360 \mathrm{~m}$ in this area, and the railway bridge from Oosterbeek, both considered vital to the success of this operation.

The "Garden" (ground) phase of the operation stipulated the advance, in the sector previously open, of the British $30^{\text {th }}$ Corps and the Armoured Division of the British $2^{\text {nd }}$ Army, accompanied by $43^{\text {rd }}$ Wessex and Northumbrian $50^{\text {th }}$ Infantry Divisions and, on a distance of $100 \mathrm{~km}$, starting from the Meuse Canal to the Escaut. These ground forces had four days to reach, one by one, the areas of action of American $101^{\text {st }}$ and $82^{\text {nd }}$ Airborne Divisions, British $1^{\text {st }}$ Parachute Division and Polish Parachute Brigade, the infantry taking over from the paratroopers their defensive missions. According to Montgomery's plan, the ground troops, supported by tanks and infantry, were to cross the Netherlands at highest speed, occupy a bridgehead across the Rhine and enter Germany. Operation "Market Garden" was meant to give the Germans the coup de grace that would eventually lead to the collapse of the Third Reich and end the war by the end of 1944 (Ryan, 1977, p. 24).

\section{ASSUMED, BUT UNJUSTIFIED RISKS}

In order to perform the airborne operation, the allies took into account the fact that the transport of troops was made at over $500 \mathrm{~km}$, requiring no less than 24 airfields to board the more than 35,000 men and heavy pieces of equipment in aircraft and gliders. Moreover, a false landing in another district was part of the plan. It was estimated that the entire operation needed more than 5,000 aircraft of all types, among which over 1,500 fighters and bombers. The use of American Dakota transport aircraft both for transporting troops and for towing gliders and the planning of troops transport based on an incorrect weather forecast extended the forces landing process on two days, with an unacceptably long delay of air support and air resupply. In fact, not even one group of forces was transported in support of paratroopers on the first day! 
A novel aspect was also the decision that the operation was to be carried out in the daytime, contrary to the usual rule that air landings must take place at nighttime, but in the moonlight. Planners thought that all the conditions for a successful landing in daytime were met, as they consider that allied fighters, which had daytime air supremacy, could neutralise the German anti-aircraft defence, and especially that it was very dangerous to deal with the Luftwaffe at nighttime. The lack of moonlight that week, as well as the advantage of easily identifying the launching areas, thus avoiding confusion after landing, were additional arguments to support the decision.

According to Cornelius Ryan, "Certain classic airborne risks had to be accepted: divisions might be dropped or landed by gliders in the wrong areas; crossings might be destroyed by the enemy even as the attack began; bad weather could make air resupply impossible; and even if all the bridges were seized, the corridor might be cut at any point. [...] The planners were gambling on speed, boldness, accuracy and surprise - all deriving from a precise synchronised land-and-airborne plan that, in its turn, gambled on German disorganisation and inadequate strength. Each link in Market Garden was interlocked with the next. If one gave way, disaster might result for all" (Ryan, 1977, p. 117). Even though such risks had to be accepted, according to the allied airborne troops headquarters: "it was not expected that any mobile force larger than a brigade group [about 3,000 men] with very few tanks and guns could be concentrated against the airborne troops before relief by the ground forces. [...] the flight and landings would be hazardous, while the capture intact of the bridge objectives was more a matter of surprise and confusion than hard fighting" (Ryan, 1977, p. 117).

Even though it can be said that the advantage of daytime parachuting was significant, as large units landed and regrouped easily in the planned areas, what the planners did not see and therefore cost the paratroopers a lot was an unexpected presence of German troops in the area. In early September 1944, the German troops from Western Europe were put under the command of Marshal Gerd von Rundstedt (instead of Marshal Walther Model), the German $15^{\text {th }}$ Army was brought from Pas de Calais, where it had waited in vain the June 1944 landings in the Netherlands, while a significant armoured force was sent on 4 September in Arnhem. In addition, the pieces of information received by the allies from the Dutch resistance were misinterpreted or even ignored by the Supreme Allied Headquarters.

\section{TOO MANY BRIDGES IN THE NETHERLANDS!}

Beginning from 13:00 in the afternoon of Sunday, 17 September 1944 (Loghin, 1984, p. 397), the American $101^{\text {st }}$ Airborne Division landed near Eindhoven, without too many launching errors (picture 1). The 501 ${ }^{\text {st }}$ Parachute Infantry Regiment, commanded by Colonel Howard R. Johnson, was headed into the direction of village of Veghel, neutralising the German resistance, and towards the four bridges over the Aa river and the Zuid Willem Canal. The 502 ${ }^{\text {nd }}$ Parachute Infantry Regiment occupied the village of St-Oedenrode and the crossing over the Dommel River quite 
easily, but had difficulties in occupying the village of Best. After the $506^{\text {th }}$ Parachute Infantry Regiment, commanded by Colonel Sink, established a bridgehead on the Wilhelmina Canal, the Division Commander decided to clear the road between Eindhoven and Grave. After heavy fighting with the German tanks, the sector was cleared, but only with the decisive intervention of the British $2^{\text {nd }}$ Army, with which the Regiment made contact (Hedny, Malcros, 1974, pp. 151-152).

The American $82^{\text {nd }}$ Airborne Division, launched at the same day in the Nijmegen region (picture 2), was made in charge of destroying the two bridges in Nijmegen (a road bridge and a railway bridge), the three bridges over the Meuse and two over the Meuse-Waal Canal. The $504^{\text {th }}$ Parachute Infantry Regiment, commanded by Colonel Reuben Tucker, conquered the bridge to the north of the village of Grave, then the one in Heumen. The bridges that were further north, after being destroyed by the Germans, were repaired and reopened for circulation. The $508^{\text {th }}$ Parachute Infantry Regiment, commanded by Colonel Roy E. Lindquist, attacked the two bridges in Nijmegen, through which the road to Arnhem passed. If this bridge, one of the most important ones in the operation, had been attacked from the first day, the chances of conquering it would have been very considerable. Instead, in the second day, the Americans had to face the strong resistance put up by the German $9^{\text {th }}$ Waffen SS Panzer Battalion. After several failed attacks, the $508^{\text {th }}$ and $504^{\text {th }}$ Regiments launched an assault on the bridges, with the help of the British $2^{\text {nd }}$ Army troops. For 8 days, the $82^{\text {nd }}$ Airborne Division controlled this sector by itself, making it possible for the forward elements of the British $2^{\text {nd }}$ Army to advance. The Division lost over 2,000 troops (Hedny, Malcros, 1974, p. 152).

The British $1^{\text {st }}$ Airborne Division was parachuted at the bridge over the Rhine at Arnhem, at $120 \mathrm{~km}$ behind the German front lines. Just as all the other bridges conquered, this one also had to be taken and kept intact until the arrival of ground forces. One hoped that the German reaction would be slow and the British, although they were short of heavy weapons, could resist, but, as General Sir Frederick Arthur Montague Browning, Commander of the British $1^{\text {st }}$ Airborne Corps, said, upon estimating that the allied tanks would not arrive on time to make the connection with the air landing, the bridge was "too far" (Ryan, 1977, p. 99).

Considering the pieces of information according to which a strong air-defence artillery and other defence forces were concentrated near the bridge, which represented the true gateway to Germany, the Division Commander, General Urquhart, chose not to launch paratroopers near the bridge, but in areas at least $10 \mathrm{~km}$ away from it, which turned out to be another critical mistake of the operation.

The British Division had the most numerous forces, receiving support from the Polish Parachute Brigade, and the Scottish 52 ${ }^{\text {nd }}$ Lowland Division had to be sent by air as soon as the runways in the vicinity Arnhem were identified and prepared. However, the poor planning of the operation caused the division to use only half of its forces in the first phase, while the other half landed only the next day (picture 3). 
Moreover, this Division had trouble with the radio communications, because of serious failure in setting them up and providing them.

The British $1^{\text {st }}$ Airborne Division led heavy fighting for nine days to conquer the bridge at Arnhem (picture 4). Although the fact that it was the least experienced large airborne unit was known, the allies made it in charge of the hardest mission, to conquer the most difficult objective, at the greatest distance. The mission to conquer the bridge was assigned to the $1^{\text {st }}$ Parachute Brigade, commanded by General Gerald Lathbury. For this, the $1^{\text {st }}$ Parachute Battalion remained in the parachuting area at the beginning, and then occupied the north of the town of Arnhem. The $2^{\text {nd }}$ Parachute Battalion, commanded by Colonel John Dutton Frost, turned south and reached western Arnhem on the morning of 18 September, but the advance was stopped by the $9^{\text {th }}$ SS Panzer Division, which had railway cannons, among others. Only a few people from the battalion escaped from this confrontation and together with Colonel Frost they managed to establish a support position west of Arnhem. The $4^{\text {th }}$ Parachute Brigade, launched late due to fog, tried to come to their rescue, but having to face a strong German retaliation itself, was reduced to the size of a company and lost a significant number of troops after carrying out a bayonet attack in order to make its way through enemy positions.

On 18 September, the $2^{\text {nd }}$ Parachute Battalion rejected two enemy attacks, but the next day Colonel Frost was seriously injured. The $3^{\text {rd }}$ Parachute Battalion, commanded by Colonel John Fitch, had the mission to attack the target from the north, but encountered strong German resistance. However, the British set up an ambush that led to the capturing of German General Friedrich Kussin, Commander of the Arnhem garrison, while returning from an inspection on the front (Hedny, Malcros 1974, pp. 153-154).

\section{THE POLISH DRAMA IN THE NETHERLANDS}

The Polish Parachute Brigade was launched near the village of Driel, with the mission to cross the Rhine River by ferry through this point and support the action of the British Division. The Germans, being warned of the passing of the aircraft that towed the gliders bringing in vehicles and anti-tank guns of the brigade, opened fire heavily. Still, the supplies and materials of the brigade were poorly parachuted, at a distance of 15 kilometres from the positions held by the Brigade. In addition, the 750 Polish paratroopers led by Sosabowski, having occupied a position on the south bank of the Rhine, were surprised to find that the ferry had been destroyed. The amphibious vehicles "Ducks", with which they tried to cross the river, got stuck and only about 50 paratroopers were able to reach the other shore. Although it was almost entirely destroyed, the Polish Brigade was unfairly accused after the war of playing a big part in the failure in Arnhem (picture 5). 


\section{THE BITTER GLORY OF WITHDRAWAL}

General Urquhart gave the order according to which a single battalion of the British Division should remain in position, the other troops being withdrawn in the Oosterbeek suburb, a few kilometres from Arnhem.

Meanwhile, the German aviation attacked the Nijmegen bridge and cut the supply road of the American $101^{\text {st }}$ Airborne Division, preventing them from making contact with the British $1^{\text {st }}$ Airborne Division. After the eighth day, in the night of 25/26 September, about 2,400 survivors from the Division were withdrawn over the river with assault boats and transported by air to Great Britain, taking off from an airfield set up near Nijmegen.

As historian Liddell Hart writes, "much of the British $1^{\text {st }}$ Airborne Division, parachuted in Arnhem, was isolated and forced to surrender, after trying to hold out until the arrival of aid, with a heroism that became legendary" (Hart, p. 228). The British lost 7,605 men and all procurement in this operation. Only 160 troops remained from the Polish Parachute Brigade (Hedny, Malcros, 1974, pp. 153-154).

\section{WHO IS TO BLAME?}

If one had to establish who was to blame for this, one should look elsewhere. First, among those who planned the operation and credited the Allied $30^{\text {th }}$ Corps with the ability to move quickly through the existing lines of communications in the Netherlands and to arrive on time to make the connection with the airborne troops launched into the enemy disposition and mostly lacking in the heavy weapons. The $30^{\text {th }}$ Corps, which ultimately had to conquer the set targets, moved very slow, on the one hand, because of a flawed concept of action (General Brian Horrocks refused to start moving until he received confirmation that the airborne troops reached their targets) and, on the other hand, because of the difficulty of moving on the single line of communication that connected all operation objectives and that could not be changed with other adjacent or detour routes due to the surrounding marshland, and to the restriction in force at that time that stipulated that tanks should move also at night. Consequently, the Guards Armoured Division and the two Infantry Divisions, which were to support the airborne action and bring the allied victory in this operation, were unacceptably late, thus allowing the Germans, who already had both ends of the bridges, to further strengthen their defensive south of Arnhem.

\section{MAJOR LOSSES, MINOR RESULTS}

According to Cornelius Ryan, the number of total allied casualties in Operation "Market Garden" was over 17,000 dead, wounded and missing. The British lost 13,226 troops (dead, wounded, missing), the $1^{\text {st }}$ Airborne Division being almost completely destroyed, as well as the Polish brigade. Only at Arnhem there were 7,872 dead, wounded and missing, including the aircraft and gliders pilots! The 
Americans lost 3,974 troops, 1,432 from the $82^{\text {nd }}$ Airborne Division and 2,118 from the $101^{\text {st }}$ Airborne Division, and the $9^{\text {th }}$ Troop Carrier Command lost 424 aircraft and glider pilots. The same author estimated the total number of German casualties: over 3,300 people, although he mentioned the number of 7,500-10,000 troops lost by the Army Group " $B$ " of General Model since the beginning of the offensive in Neerpelt, then along the corridor, in the battles at Nijmegen, Grave, Veghel, Best and Eindhoven (Ryan, 1977, p. 532).

Due to poor initial planning (which was not even respected entirely, especially by the $30^{\text {th }}$ Corps), Operation "Market Garden" had minor results. Because of the unacceptably long delay of ground forces, their timely junction with the air landing at Arnhem failed, therefore, they could not benefit from the advantage of surprise, the trump card of airborne operations, because of the precise reaction of the Germans. They gained only a corridor of $80 \mathrm{~km}$, and the bridge at Arnhem was still in German hands. The attempt of reversing the "Siegfried" line fortification by surprise failed (Ciobanu, Popa, Pricop, 1988, p. 154).

\section{THE CAUSES FOR A ... PLANNED FAILURE}

Among the reasons for this indisputable failure, one may be mentioned:

- incorrect assessment of enemy's possibilities: the Germans had the $2^{\text {nd }}$ and $9^{\text {th }} \mathrm{SS}$ Panzer Divisions in the area, transferred from France, as well as the $10^{\text {th }}$ and $16^{\text {th }}$ SS Panzer Divisions, which were moving from Denmark to Westphalia; a series of information from the Dutch resistance, about the existence of several tanks formations sent from Germany in the Arnhem area, could not be verified due to the short time available. Such pieces of information were not included in the research briefings that were sent to the Higher Allied Headquarters. Although extremely careful and thorough in everything he did his entire career, Marshal Montgomery seemed to have ignored or undervalued the possibilities for retaliation of the Germans this time:

- the engagement of numerous, interconnected forces, in an area with limited communication system; it was believed that once the bridges were conquered, the tanks of the British $30^{\text {th }}$ Corps could easily go through this narrow corridor and enter Germany with no difficulty (Ryan, 1977, pp. 118-119). However, the allied tanks were not able to move outside the ordinary roads, due to the many canals in the area. On the only existing road, which was quite unpredictable, the tanks could move only in single file, and the infantry was unable to accompany them and intervene when necessary;

- German General Walther Model, Commander of Army Group "B”, was at that time only a few kilometres from Arnherm, at Oosterbeck, and could respond immediately. Moreover, the Germans were organising an airborne army at that moment, consisting of six divisions of paratroopers who, even though lacked the combat experience of the veterans from Crete, were still able to react 
immediately; General Kurt Student, Commander of this army that was undergoing an organisation process, obtained the Operation "Market-Garden" Plan, found onboard of one of the gliders shot down by German anti-aircraft artillery, and thus had the opportunity to properly retaliate against allied airborne troops;

- the inclement weather hindered the planned development of actions, and the fact that paratroopers were launched far from their targets, as was the case in Arnhem, created a great difficulty: the troops were engaged in battle and lost their combative capacity long before reaching the target. The second air transport to Arnhem (troops, equipment, ammunition) arrived only the following day, at 14:00, therefore, the subsequent resupply of the forces engaged in combat and the restoring of their capacity was very delayed.

\section{THE CONSPIRACY OF ... ERRONEOUS AND IGNORED INFORMATION}

Of course, the conspiracy theory was present as well. French historian Jacques de Launay showed that, in order to justify the failure, allied intelligence services came up with the idea of betrayal, on the part of a member of the Dutch resistance, Cristiaan Lindemans, who was said to have sent to the service Abwehr III F a letter addressed to British fighters from the Dutch resistance who were ordered to wait for weapons and instructions before triggering the insurrection. De Launay believes that this "King Kong" (as the Dutch was called) could not have sent the message before 15 September, when the two German tank divisions were already in motion since 8 September, and the message contained only the information of a possible offensive area and not a certainty (Launay, 1988, p. 219).

Therefore, even if it represents one of the pages of glory of airborne troops, Operation "Market Garden", one of the most controversial military operations, meant a serious error of allied strategy.

\section{THE LAST JUDGMENT}

After the war, Montgomery called "the battle of Arnhem 90\% successful” (Ryan, 1977, p. 8), yet, he also said bitterly "every allied victory is an American success and every allied defeat a British failure". Winston Churchill said "the battle of Arnhem involved high risks, but they were justified by the intended purpose, so close to being reached. [...] The battle was a decided victory, although the vanguard division, asking in vain for reinforcements, was destroyed" (Ryan, 1977, p. 9). D.D. Eisenhower, in turn, said that "the attack began well and unquestionably would have been successful except for the intervention of bad weather. This prevented the adequate reinforcement of the northern spearhead and resulted finally in the decimation of British airborne division and only a partial success in the entire operation. We did 
not get our bridgehead but our lines had been carried well out to defend the Antwerp base" (Eisenhower, 1975, p. 415).

American historian Charles B. MacDonald disagrees, saying the operation was a failure, even if at first glance it would seem that this failure "was to blame on the Goddess of Fortune: the number of SS tank divisions, the active presence of German Generals Model and Student, the capturing of the operational order of allies, the bad weather". However, the American historian believes that "Operation $<$ Market Garden> could have succeeded if the British infantry column had attacked with greater vigour the southern Eindhoven and the region of northern Waal and if the American $82^{\text {nd }}$ Division had shown the verve and vigour expected from such troops and had assigned at least a small force to support those who fought at the big bridge on the Waal at Nijmegen” (Eisenhower, 1975, p. 10).

In turn, Jacques de Launay says with certainty that "the Battle of Arnhem, the largest airborne action in history, ended in an undeniable defeat", pointing out that although the American $82^{\text {nd }}$ and $101^{\text {st }}$ Airborne Divisions were maintained in the sectors Nijmengen and Eindhoven, making the contact with ground troops, the main goals of Operation “Market Garden” were not achieved, as the Germans continued to hold the entire area along the Rhine and resist in the Netherlands until 27 March 1945. The V-2 rocket bases remained intact, and the port of Antwerp remained unusable (Launay, 1988, p. 219).

The words of Romanian historian Cristian Popişteanu written in Cornelius Ryan's book foreword seem to be extremely meaningful in this respect: "In Arnhem, an epic was written and a tragedy was played" (Ryan, 1977, p. 9).

The failure of allied airborne forces in the Netherlands was not an end of road, as in the case of the German troops after operation "Mercury", but a new beginning whose results were mostly seen on the active theatres of military actions after the Second World War.

Conclusion Contrary to all expectations, Operation "Market Garden" had minor results. Planned and originally credited as one of the most spectacular military operations of the Second World War, although part of a page of (bitter!) glory of airborne troops, it remains controversial, being a serious strategy error of allies, in which the omission, ignorance or lack of adequate capitalisation on the intelligence gathered had significant effects.

The role of intelligence in military actions is a truism and I do not want to go into all the details right now, but by bringing to the attention of our contemporaries the importance of intelligence in designing, planning, implementing and exploiting the results of an already famous military action of the Second World War, I tried to emphasise the need for detailed knowledge and for taking into consideration, during the strategic planning, all the elements that can influence, in one way or another, the 
conduct of an operation, regardless of its objectives and scope. This is a principle whose validity is further validated by the successes and sometimes failures of a military action conducted in various areas of post-war conflict.

The nature and real dimension of current and future threats cannot be predicted accurately, but obtaining, identifying and sending them to the beneficiaries certainly creates the possibility of a well-documented evaluation and the development of a political-military course of action with real chance of success.

Intended to support the decision-making process, the intelligence will often have to act as a replacement for the lack of sufficient data about the enemy, but by an optimal management of all information networks and an effective cooperation between the related services, at national and international level, information superiority will be ensured (Botoş, 2014, p. 66). Acquiring strategic intelligence timely and before the opponent, choosing the right time and procedures appropriate to surprise the opponent, exploiting certain geophysical and environmental characteristics able to benefit own troops and seriously assessing the risks and threats are all vital to the success of any military action.

1. Botoş, Ilie, 2014. Adaptarea informaţiilor pentru apărare în funcţie de riscurile şi ameninţările noului mileniu. In Infosfera, no. 2/2014, p. 66.

2. Ciobanu, Nicolae, Popa, Costică, Pricop, Vasile, 1988. Curs de istoria artei militare, vol. III, Bucureşti: Editura Academiei Militare.

3. Eisenhower, Dwight D., 1975. Cruciadă în Europa, Bucureşti: Editura Politică.

4. Hedny, Philippe, Malcros, Christian (coord.), 1974. Histoire mondiale des parachutistes, Paris: Société de Production Littéraire.

5. Launay, Jacques de, 1988. Mari decizii ale celui de-al doilea război mondial, vol. II, Bucureşti: Editura Ştiințifică şi Enciclopedică.

6. Loghin, Leonida, 1984. Al doilea război mondial, Bucureşti: Editura Politică.

7. Ryan, Cornelius, 1977. Un pod prea îndepărtat, Bucureşti: Editura Politică.

8. Sainte-Croix, Philip de, 1978. Histoire des opérations aéroportèes. Brussels: Elsevier Sequoi (French edition, translated and adapted after Airborne Operations, 1979, London: Salamander Books Ltd.). 
Viktor Potočnik

\title{
OBSEG IN KARAKTER SLOVENSKE VOJSKE
}

\author{
SLOVENIAN ARMED FORCES SIZE \\ AND CHARACTER
}

Povzetek Besedilo obravnava vprašanji o obsegu in karakterju Slovenske vojske (SV). Že nekaj časa se namreč pojavljajo zamisli o nadaljnjem zmanjševanju stalne sestave SV, ki zaradi omejenih finančnih sredstev dobivajo še dodaten zagon. V članku je kratek zgodovinski pregled obsega oboroženih formacij slovenskega naroda v luči izpolnjevanja nalog SV, kot so zapisane v Zakonu o obrambi (ZoObr). Obravnavam tudi karakter SV in osrednjega vira njene bojne moči, in sicer pehote. Vojske v zavezništvu in širše poznajo več tipov pehote, kar je treba upoštevati, ko razmišljamo o tem, kakšno pehoto bomo v SV imeli. Seveda se zavedamo finančnih omejitev, ki jim je SV izpostavljena, zato v sklepnem delu predstavljamo nekaj predlogov, kako uresničiti predlagana obseg in značaj SV, ki so namenjeni dodatni razpravi in bi bili potrebni bolj poglobljene analize.

Ključne Obseg oboroženih sil, Slovenska vojska, Nato, pehota, stalna sestava, vojaška besede strateška rezerva.

Abstract The text deals with the questions of the size and character of Slovenian Armed Forces (SAF). For some time now one has been able to track ideas of decreasing the size of the SAF active component, which have additionally gained momentum due to the limited defence resources. The texts looks at the size of Slovenian armed structures from the historic perspective in the light of the tasks set before SAF by the Defence Act. The article also deals with the SAF's character and the source of its fighting power - the infantry. Allied and other armies list several types of infantry, the fact which should be taken into consideration when deliberating on the type of infantry in the SAF. Of course, we are aware of the financial restrictions imposed on the SAF; therefore the conclusion includes some suggestions on how to achieve the proposed size and character of the SAF. The suggestions, however, are intended more as a base for a discussion and would have to be further analysed. 


\section{Key words Size of armed forces, Slovenian Armed Forces, NATO, infantry, active component, military strategic reserve.}

Uvod Teritorialna obramba Republike Slovenije (v nadaljevanju TORS) je na vrhuncu moči obsegala vojno sestavo z več kot 80.000 pripadniki. V resnici jih nikoli ni bilo toliko tudi mobiliziranih, toda njena vojna formacija je omogočala tolikšen obseg. Po končani osamosvojitveni vojni in pozneje, s koncem oboroženih spopadov na ozemlju nekdanje Jugoslavije, se je obseg TORS in pozneje SV postopoma spreminjal. Z vojne sestave 54.000 pripadnikov leta 1994 do največ 73.000 leta 2001 in 39.000 v letih 2002 in 2003 in 16.000 leta 2004 (Grizold, 2005, str. 125, 127) do zdaj dovoljenih 10.000. Ob tem sta SV in prej TORS večino časa ohranila karakter lahke pehotne vojske $\mathrm{z}$ majhno manevrsko in večjo prostorsko strukturo. ${ }^{1}$ Že nekaj časa se pojavljajo tudi bolj ali manj uradne zamisli o tem, da bi bilo treba obseg in strukturo SV še zmanjšati. Ob tem se večinoma omenja številka okoli 5000 pripadnikov. Hkrati znotraj SV in tudi v zainteresirani javnosti potekajo neuradne razprave o tem, kakšen naj bo sploh karakter SV.

Obseg in karakter SV se ugotavljata z nalogami, ki so zaupane SV, z grožnjami, ki jim je RS izpostavljena, in z njeno vključenostjo v zavezništvo. Upoštevati pa moramo tudi zgodovinske izkušnje oziroma obseg in karakter oboroženih sil slovenskega naroda od začetka 19. stol. naprej. SV je in bo predvsem kopenska vojska s pehoto kot njenim osrednjim rodom, ki je osrednji vir njene bojne moči. Drugi rodovi in službe so v funkciji podpore ali zagotovitve delovanja pehote v omejenem obsegu, delujejo pa lahko tudi samostojno. V okviru pehote kot osrednjega rodu in izvora bojne in nebojne moči SV se zastavlja vprašanje, kakšno pehoto sploh potrebujemo. Ni namreč vsak tip pehote primeren za naloge in vire, ki jih ima SV.

\section{NALOGE SLOVENSKE VOJSKE IN NATA}

Naloge SV izhajajo iz ZoObr (37. člen) in so:

- izvajanje vojaškega izobraževanja in usposabljanja za oboroženi boj in druge oblike vojaške obrambe;

- zagotavljanje potrebne ali zahtevane pripravljenosti;

- ob napadu na državo izvajanje vojaške obrambe;

- ob naravnih in drugih nesrečah skladno s svojo organizacijo in opremljenostjo sodelovanje pri zaščiti in reševanju (ZiR);

- izvrševanje obveznosti, ki jih je država sprejela v mednarodnih organizacijah in z mednarodnimi pogodbami.

\footnotetext{
$V$ devetdesetih je veljala delitev na manevrske in prostorske sile, nato se je leta 2001 delitev spremenila $v$ sile za posredovanje, glavne sile in dopolnilne sile, da bi se leta 2004 dokončno poenotila z zavezništvom. Zdaj delimo sile SV glede na vlogo v sistemu bojevanja na sile za bojevanje, sile za bojno podporo, sile za zagotovitev bojnega delovanja in sile za podporo PINK, in sicer glede na sposobnost premeščanja (premestljive in nepremestljive sile) in glede na stopnjo pripravljenosti (sile v visoki stopnji pripravljenosti, sile v nizki stopnji pripravljenosti in sile z daljšim časom vzpostavitve pripravljenosti) (Grizold, 2005, str. 134, 135, 136).
} 
Naloge iz ZoObr so jasne. SV mora izvajati vojaško obrambo ob napadu, ob večjih nesrečah sodeluje v ZiR in izpolnjuje mednarodne obveznosti, ki jih vojska lahko izpolnjuje. Zato mora izvajati usposabljanje in zagotavljati ustrezno pripravljenost. Poslanstvo SV je z različnimi strateškimi dokumenti različno opredeljeno.

Resolucija o splošnem dolgoročnem programu razvoja in opremljanja SV do leta 2025 (ReSDPRO) opredeljuje kot namen SV, da »z vojaškimi zmogljivostmi prispeva $\mathrm{k}$ uresničevanju interesov in nacionalnovarnostnih ciljev Republike Slovenije« (DZRS, 2010, str. 10), kot poslanstvo SV pa ReSDPRO SV 2025 v bistvu povzame naloge iz ZoObr.

Obrambna strategija RS kot poslanstvo SV navaja, da »z vojaškimi zmogljivostmi zagotavlja vojaško moč RS, kot najmočnejši in skrajni instrument države za uveljavljanje oz. uresničevanje njenih nacionalnih interesov in nacionalnovarnostnih ciljev.« (Vlada RS, 2012, str. 9).

Vojaška doktrina iz leta 2006 kot poslanstvo SV navaja: »Poslanstvo Slovenske vojske je v sodelovanju z zavezniki odvrniti vojaško agresijo na Republiko Slovenijo in prispevati $\mathrm{k}$ mednarodnemu miru in stabilnosti v mejah in zunaj meja zavezništva. $\mathrm{V}$ primeru vojaške agresije Slovenska vojska samostojno in $\mathrm{V}$ sodelovanju $\mathrm{z}$ zavezniki izvaja vojaško obrambo Republike Slovenije s ciljem pregona sovražnika in vzpostavitve suverenosti na celotnem ozemlju države.« (Furlan, 2006, str. 24).

Na podlagi omenjenega lahko ugotovimo, da strateški dokumenti poslanstva SV ne opredeljujejo enotno, kar ima lahko negativne posledice. Poslanstvo, kot je zapisano v ReSDPRO SV 2025 in Obrambni strategiji, se nanaša na tako imenovano veliko strategijo $^{2}$ države in obravnava njeno vlogo $\mathrm{v}$ odnosu do nacionalnovarnostnih interesov oziroma ciljev. Poslanstvo, povzeto iz vojaške doktrine, pa bolj konkretizira način delovanja SV pri sledenju tem ciljem in pomeni boljši okvir za razpravo o karakterju in obsegu SV.

Na podlagi strateških dokumentov torej lahko sklenemo, da je obrambna strategija RS odvračalna in da se za zagotavljanje lastne varnosti večinoma zanaša na zavezništvo. Pri tem se lahko hitro znajde v pasti prevelikega prelaganja odgovornosti za lastno varnost na druge članice zavezništva, zato je treba dobro razumeti, kakšno in kolikšno varnost daje zavezništvo. Menim, da je v tem pogledu ključno poznavanje in razumevanje 3. in 5. člena Severnoatlantske pogodbe.

Peti člen pogodbe pravi: »Pogodbenice soglašajo, da se oboroženi napad na eno ali več pogodbenic v Evropi ali Severni Ameriki šteje za napad na vse pogodbenice, in zato soglašajo, da bo v primeru takega oboroženega napada vsaka od njih ob uresničevanju pravice do individualne ali kolektivne samoobrambe, ki jo priznava 51. člen Ustanovne listine Združenih narodov, pomagala tako napadeni pogodbenici ali pogodbenicam $s$ takojšnjim individualnim in $z$ drugimi pogodbenicami

2 Pojem uporablja Barry Posen v svoji knjigi in se nanaša na nacionalnovarnostne strategije držav. 
dogovorjenim ukrepanjem, ki se ji zdi potrebno, vključno z uporabo oborožene sile, da se ponovno vzpostavi in ohranja varnost severnoatlantskega območja. ${ }^{3}$

Peti člen sicer res govori o tem, da je napad na eno članico zavezništva napad na vse, toda hkrati vsaki posamezni državi omogoča, da se na njej lasten način odzove na ta napad. Oborožena sila je le eden izmed načinov, na katerega se lahko odzovejo, kar pomeni, da napad na RS ne bi nujno pomenil pomoč zavezništva v obliki, kakršno bi pričakovali. Zavezništvo nima lastnih oboroženih sil, temveč gre za sile, ki jih prispevajo v skupna poveljstva posamezne članice. Zavezništvo nas dela varnejše le v povezavi z globalnimi grožnjami, ki bi ogrožale tako Slovenijo kot večino zaveznic oziroma vsaj najmočnejše države zaveznice. Ob lokalni grožnji pa je zanašanje na zavezništvo vprašljivo.

Tretji člen Severnoatlantske pogodbe pravi: »Za učinkovitejše doseganje ciljev te pogodbe bodo pogodbenice $\mathrm{z}$ nenehno in učinkovito samopomočjo ter vzajemno pomočjo vsaka zase in skupaj vzdrževale in razvijale svojo individualno in kolektivno sposobnost upreti se oboroženemu napadu. $\ll^{4}$

Tretji člen pogodbe jasno postavlja zahtevo, da vsaka država članica sama razvija lastne zmogljivosti za obrambo pred oboroženim napadom. Zato se ne moremo strinjati z dr. Grizoldom, ki trdi, da »delitve vojaških zmogljivosti na nacionalnoobrambne potrebe in na tiste, ki so na voljo Natu, skoraj ni več«. (Grizold, 2005, str. 187). Članice, med njimi tudi RS, morajo razvijati lastno sposobnost za obrambo pred napadom. ${ }^{5}$ Če članica ne izpolnjuje zahtev tega člena, tudi ne more pričakovati, da bodo druge članice zapolnjevale manke v njenih obrambnih zmogljivostih.

Zavezništvo ima svojo ceno in nobena članica si ne bi smela dovoliti, da zanemarja lastne obrambne zmogljivosti in se pri tem sklicuje na varnost, ki naj bi jo zagotavljal 5. člen pogodbe. Zavezništvo je lahko učinkovito le takrat, če vse zaveznice izpolnjujejo svoje zaveze. Realnost je seveda drugačna in kaže, da politika pogosto prelaga odgovornost za varnost lastne države na druge zaveznice in s tem zanemarja lastne zmogljivosti. Članstvo je lahko izjemno koristno zaradi deljenih zmogljivosti in zmanjševanja stroškov v skupnih projektih. Če se torej RS odpove na primer oklepnim (tankovskim) zmogljivostim, zračni obrambi (ZO), vojaškemu letalstvu in

\footnotetext{
"The Parties agree that an armed attack against one or more of them in Europe or North America shall be considered an attack against them all and consequently they agree that, if such an armed attack occurs, each of them, in exercise of the right of individual or collective self-defence recognised by Article 51 of the Charter of the United Nations, will assist the Party or Parties so attacked by taking forthwith, individually and in concert with the other Parties, such action as it deems necessary including the use of armed force, to restore and maintain the security of the North Atlantic area ... " (http://www.nato.int/ cps/en/natolive/official_texts_17120.htm)

4 "In order more effectively to achieve the objectives of this Treaty, the Parties, separately and jointly, by means of continuous and effective self-help and mutual aid, will maintain and develop their individual and collective capacity to resist armed attack." (http://www.nato.int/cps/en/natolive/ official_texts_17120.htm)

5 Ob najnovejšem valu terorističnih groženj, po napadu na francoski satirični časopis, sta Francija in Belgija na ulice za zagotavljanje varnosti napotili svoje vojake, neodvisno od zavezništva. To so lahko hkrati iste zmogljivosti, ki so na voljo zavezništvu, a dejstvo je, da so nacionalnovarnostne potrebe ločene od zavezništva, kot je dokazal tudi Afganistan, kjer je kljub aktivaciji petega člena trajalo skoraj dve leti, preden se je preostanek zavezništva dejavno vpletel $v$ konflikt.
} 
drugemu, mora imeti jasen načrt, kako bo primanjkljaj teh zmogljivosti nadomestila znotraj zavezništva: ali bo investirala v boljše protioklepne zmogljivosti, skupni sistem zračne obrambe, regionalne zračne sile itn. Slovenija je znotraj zavezništva že našla rešitve za popolnitev primanjkljajev nekaterih zmogljivosti, vsega pa se ne da rešiti skozi zavezništvo. Zagotovo ne z obrambnimi izdatki v višini 1,1% BDP, pri čemer gre za potrebe SV le 0,74 \% BDP. Preostalo gre za druge udeležence obrambnega sistema RS, za civilno zaščito, gasilce idr. (predavanje NGŠSV http:// youtu.be/tEHYGFWO7pQ, od 12.30 do 12.45).

Čeprav v zavezništvu države delijo tveganja, stroške in koristi vojne, pa prinaša zagotavljanje varnosti znotraj zavezništva tudi velike nevarnosti. Države znotraj zavezništev odgovornost za lastno varnost prepuščajo drugim, kar vodi v nerealno zmanjševanje lastnih virov za potrebe varnosti. Druga past zavezništva je pristajanje na vojaško doktrino vodilne nacije, čeprav ta morda ni primerna za majhno državo (Posen, 1984, str. 73). Menimo, da je primer takega zavezništva tudi Nato, pri čemer ZDA, ki imajo izrazito ofenzivno vojaško doktrino, bolj ali manj odkrito vodijo tudi vse druge zaveznice v podobno doktrino. Tako je tudi SV kljub svoji deklarativni zavezanosti odvračalni doktrini strukturno bolj podobna vojski, ki razvija ofenzivno doktrino. ${ }^{6}$

Slovenska politika in javnost se morata jasno zavedati, da smo za varnost lastne države odgovorni predvsem sami in da bo ekstremno varčevanje na obrambnih zmogljivostih pustilo resne posledice.

\section{VARNOSTNE GROŽNJE IN IZZIVI REPUBLIKE SLOVENIJE}

Družba v postmoderni dobi se srečuje s številnimi bolj ali manj verjetnimi grožnjami. Moskos pravi, da »bodo najverjetnejša grožnja državi v postmoderni družbi še dolgo različna revolucionarno/teroristična gibanja« (Moskos v Bebler, 2005, str. 316). Vendar ob tem ne moremo odpisati groženj, ki jim je bila država izpostavljena $\mathrm{v}$ tradicionalni in moderni dobi. ${ }^{7}$ Kot pravi Dandeker, imajo postmoderne oborožene sile »izjemno širok spekter obrambnih nalog in vlog « ter morajo imeti temu primerno strukturo poklicne in rezervne sestave, da bi vse to lahko opravljale (Dandeker v Moskos, 2000, str. 45). Moskos za postmoderne vojske poleg drugih značilnosti izpostavlja tudi spremembo v namenu vojske od zmage v vojni do nalog, ki niso vojaške $\mathrm{v}$ tradicionalnem smislu, in udeležbo vojske na misijah z mednarodno legitimnostjo (Moskos, 2000, str. 2).

\footnotetext{
Ob tem ne smemo zamenjevati ofenzivne doktrine na strateški ravni z ofenzivnostjo na taktični ravni. Tudi vojske, ki na strateški ravni razvijajo defenzivno ali odvračalno doktrino, lahko in celo morajo razviti ofenzivno doktrino na taktični ravni, pri čemer je treba $v$ boju prevzemati iniciativo in posegati v nasprotnikov cikel odločanja. To zagovarja funkcija poveljevanja in kontrole na podlagi poslanstva, kot jo pozna tudi Vojaška doktrina SV, in o kateri sem več pisal v SV junij $2014-16$, št. 2.

Tradicionalne družbe naj bi obstajale do konca druge svetovne vojne, zanje so bile značilne množične nacionalne vojske, moderne družbe pa od konca druge svetovne vojne do konca hladne vojne, zanje so bile značilne vojske s profesionalnim častniškim zborom, zmanjšanim obsegom in naprednim izobraževanjem. Za postmoderne družbe po koncu hladne vojne so značilne vojske, v katerih so meje med civilno in vojaško sfero zabrisane (Moskos v Bebler, 2005, str. 313).
} 
Ne gre za to, katera od groženj je verjetnejša ali pomembnejša. V svetu, ki je tako medsebojno povezan in nestabilen, kot je današnji, je grožnje na dolgi rok nemogoče prioritizirati. Grizold ugotavlja, da je v svetu po hladni vojni grožnjam skupno nekaj elementov (Grizold, 2005, str. 22, 23):

1. povezovanje, prepletanje in medsebojno učinkovanje vojaških in nevojaških groženj varnosti;

2. preraščanje nacionalne varnosti v mednarodno varnost in obratno. Varnost ima danes globalne razsežnosti v prostorskem in vsebinskem smislu. Tako je tudi varnost posamezne države vse bolj domena globalnega mednarodnega sistema;

3. znatno sta se okrepili povezanost in odgovornost med subjekti zagotavljanja varnosti, kot so država, meddržavne in naddržavne organizacije, nevladne organizacije, multinacionalne korporacije, skupine pritiska idr.;

4. instrumenti in mehanizmi za zagotavljanje varnosti so bolj zapleteni in se povezujejo v sistem tako na ravni države kot na ravni mednarodne skupnosti.

Treba je imeti sistem, ki bo zasnovan tako, da se bo lahko ustrezno odzval na vse grožnje in bo finančno vzdržljiv.

Tudi strateški obrambno-varnostni dokumenti RS ugotavljajo podobno in groženj ne prioritizirajo. Ugotavljajo, da je na kratki in srednji rok verjetnost neposredne vojaške grožnje RS majhna, toda ne izključujoča. Hkrati pa asimetrični značaj groženj in njihove hibridne oblike zahtevajo tako nevojaško odzivanje na vojaške grožnje kot vojaško odzivanje na nevojaške grožnje (Obr. strat. RS, 2012, str. 3). Če bi se lahko kaj naučili iz sodobnih kriz in spopadov, je to, da so nepredvidljive. Predvsem pa je nepredvidljiva smer razvoja, ki jo bodo izbrale - bodo ostale lokalne, se bodo razvile v regionalne ali postale celo širše in ne nazadnje globalne. Mednarodni varnostni sistem je preprosto preveč nepredvidljiv in interesi, ki bodo prevladali, niso vnaprej določljivi, da bi lahko z veliko gotovostjo ocenili razvoj dogodkov. To potrjujeta zadnja dva primera krize v Ukrajini, ki je stresla in še vedno stresa celotno Evropo, in uspehi sil Islamske države (ISIL) v Iraku in Siriji.

Če povzamemo dr. Grizolda »sodobno ogrožanje varnosti vključuje poleg konvencionalnih groženj (npr. vojna, oboroževalne tekme, širjenje jedrskega orožja idr.) tudi nevojaške grožnje, ki postajajo vse bolj aktualne, na primer množično nespoštovanje temeljnih človekovih pravic in svoboščin, onesnaževanje okolja in posledično segrevanje ozračja, lakota, nalezljive bolezni, trgovina z drogami in belim blagom, nenadne migracije idr. Omenjene grožnje varnosti so skupaj z mednarodnim terorizmom, orožjem za množično uničevanje ter tako imenovanimi nefunkcionalnimi državami, ki ne ogrožajo le lastnega prebivalstva, temveč destabilizirajo celotno regijo, postali temeljni viri ogrožanja sodobne varnosti. Tovrstne kompleksne grožnje varnosti pa zahtevajo enako kompleksne rešitve.« (Grizold, 2005, str. 24).

Obrambno-varnostni sistem Republike Slovenije in predvsem SV mora tako težiti k čim večji fleksibilnosti njene strukture in posameznikov, ki jo sestavljajo. SV mora 
biti pripravljena tako na vojaške grožnje nacionalnemu ozemlju kot na naravne in druge nesreče ter na kibernetske grožnje in delovanje na kriznih območjih po svetu. Ni je organizacije, ki bi se bila sposobna odzivati na vse te grožnje hkrati, in tudi vojska ne bo v vseh primerih prevzemala vodilne vloge. So pa grožnje, pri katerih je treba prevzemati pobudo. To so tradicionalne vojaške grožnje nacionalnemu ozemlju in sodelovanje v mednarodnih operacijah in na misijah. Povsod drugod bo Slovenska vojska sodelovala, ponekod pretežno z moštvom in tehniko, na primer ZiR, drugje s posameznimi specializiranimi elementi, kot je kibernetska obramba, ali specializiranimi posamezniki, na primer v boju proti terorizmu.

Ključ je fleksibilnost, ki mora biti vgrajena v sistem in del vsakega posameznika v sistemu.

\section{OBSEG SLOVENSKE VOJSKE}

Izbira vojaške doktrine posamezne države v okviru tako imenovane velike državne strategije je odvisna od tega, kakšni naj bi bili karakter, obseg in struktura njenih oboroženih sil. Posen razlikuje med ofenzivnimi, defenzivnimi in odvračalnimi vojaškimi doktrinami. Cilj ofenzivnih doktrin je razorožitev nasprotnika oziroma uničenje njegovih oboroženih sil, cilj defenzivnih doktrin pa je, da se nasprotniku prepreči doseganje zastavljenih ciljev. Odvračalne doktrine imajo kot cilj kaznovanje nasprotnika, in sicer tako, da povečujejo njegove stroške (materialne, kadrovske in finančne), ne da bi pri tem zmanjševale svoje vire (Posen, 1984, str. 14).

Vojaška doktrina SV je, glede na veljavne strateške dokumente in veljavno vojaško doktrino, odvračalna. V vojaški doktrini piše, da je »Poslanstvo $S V$... odvrniti vojaško agresijo ...« (Furlan, 2006, str. 24). SV bi torej s svojim značajem, strukturo in obsegom morala služiti predvsem odvračanju morebitne nevarnosti. Seveda na SV in vojaško varnost Republike Slovenije ne moremo gledati ločeno od zavezništva. Dejstvo je, da članstvo v zavezništvu deluje odvračalno vsaj do konvencionalnih agresorjev. Se pa v delovanju zavezništva še vedno kaže kriza identitete (Grizold, 2005, str. 92, 93), ki je nastala ne le s koncem hladne vojne, temveč predvsem s spremenjeno percepcijo tega, kaj koncept varnosti po 11. septembru v resnici pomeni. Zavezništvo se po vrhu v Walesu jasneje zaveda, da se mora odločneje spopasti z novimi oblikami groženj ${ }^{8}$, in se je zavezalo, da bo odločneje pristopilo k razvoju zmogljivosti za spoprijemanje z njimi (Declaration, 2014, t. 64). Zavezništvo ima med svojimi temeljnimi nalogami navedeno odvračanje in obrambo pred grožnjo z agresijo kateri koli članici, a hkrati ugotavlja, da je konvencionalna agresija velikih razsežnosti proti zaveznicam malo verjetna, se je pa na daljši rokne da odpisati (NATO, AJP-01(D), str. 2-2 in 2-3). Doktrinarni dokumenti ugotavljajo, da so verjetnejše operacije odzivanja na krizne situacije ter transnacionalne in hibridne nasprotnike.

\footnotetext{
8 Zavezništvo govori o transnacionalnih in multidimenzionalnih grožnjah, o hibridnih grožnjah, terorizmu in nevarnosti, ki jo pomenijo balistični izstrelki (Declaration, 2014, t. 13, t. 32, t. 55). Tem grožnjam je skupno to, da za tarče nimajo le vojaških ciljev, temveč predvsem politične. Tako hibridne grožnje obsegajo mešanico odkritih in prikritih vojaških, paravojaških in civilnih groženj, skladno s trenutno situacijo.
} 
Tako je zavezništvo tudi strukturirano in v tej smeri bo potekalo njegovo nadaljnje preoblikovanje (Declaration, 2014, t. 64), taka pa bodo tudi pričakovanja do vseh članic. Skladno s Posnovimi definicijami vojaške doktrine menim, da je doktrina zavezništva ofenzivna, saj predvideva kratke in bliskovite spopade na ozemlju, ki ni domače, in daje velik poudarek silam, ki so visoko odzivne in strateško premestljive.

Temu sledi tudi SV, katere trenutni mirnodobni obseg in struktura sledita usmeritvam zavezništva, razen vojaške strateške rezerve9. Nikakor pa ne zadošča odvračanju morebitnih nasprotnikov z lastnimi oboroženimi silami, pri čemer bi morebitnemu nasprotniku lahko povzročali toliko izgub in tako dolgo, da oborožena agresija zanj ne bi bila smiselna. Tudi doktrina VSR RS navaja, da »morajo biti možne koristi potencialnega agresorja bistveno manjše od škode, ki mu jo lahko ... povzročimo kot morebitna žrtev napada« (MO RS, 2012, str. 6). Zavezništvo je v tem trenutku edini odvračalni element obrambne doktrine RS, SV pa v zdajšnji obliki ni primerna za doktrino odvračanja. Za Republiko Slovenijo in SV je odvračalna doktrina edina smiselna, saj majhne države z zelo omejenimi viri nimajo pogojev, da bi razvile ofenzivne ali defenzivne doktrine. Hkrati Republika Slovenija nima druge možnosti, kot da svojo varnost zagotavlja znotraj zavezništva. Druga možnost je še nevtralnost, vendar bi morala za to pridobiti ustrezna varnostna zagotovila $\mathrm{v}$ mednarodni skupnosti, ki pa je dolgoročno nepredvidljiva in anarhična. Za kaj takega Slovenija nima realnih možnosti in tveganje, ki bi se mu ob tem izpostavila, je nesprejemljivo.

Trenutni koncept strateške rezerve SV predvideva povečanje njenega obsega do 25.000 pripadnikov v enem letu (Doktrina VSR RS, 2012, str. 10, 24). Menim, da je to nerealno, saj SV nima več nobene rezerve, razen pogodbene rezerve (v nadaljevanju PPRS), ki pa ni namenjena rasti vojaške strateške rezerve, temveč zapolnitvi aktivne sestave SV. Uprave za obrambo sicer vpisujejo v vojaško evidenco, vendar vpisani državljani ne prejmejo obvestila o vojaškem usposabljanju, niti se ne spremlja njihova sposobnost za opravljanje vojaške službe. SV tudi nima načrtov, kako te evidence uporabiti in kaj storiti, če pride do tega, da jih bo treba uporabiti. Ob upoštevanju tempa sodobnega vojskovanja in razvijanja kriznih situacij SV ne bo imela leto dni časa, da se pripravi na morebitno grožnjo. Prav tako se ne ve, kako bi politika sprejela tako radikalno odločitev, kot je mobilizacija vojaške strateške rezerve leto dni vnaprej, ob tem, da ni nikakršnega zagotovila, da bo neka kriza oziroma vojna prerasla v spopad takih razsežnosti, ki bi ogrožal tudi Slovenijo. SV prav tako nima dovolj vodij, ki bi lahko usposobili 25.000 pripadnikov. Od kje bi namreč prišel kader, ki bi v enem letu usposobil vodje za strateško rezervo. Zavedati se je treba, da bi se velik del SV, predvsem njen najbolj usposobljeni del, ukvarjal z izvajanjem operativnih nalog, ki bi jih bilo v krizi gotovo veliko (med drugimi tudi izpolnjevanje obvez do zavezništva). Drugorazredni kader pa lahko usposobi kvečjemu tretjerazredni starešinski kader strateške rezerve. Morebitno usposabljanje v razmerah okupacij bi bilo tudi izjemno oteženo, predvsem pa počasno.

Koncept vojaške strateške rezerve (VSR) je le formalen, zapisan na papirju, in ni natančno razdelan niti preizkušen, zato ne more in ne bo zaživel. 
Načrti za povečevanje obsega SV, ki so znani samo v obliki koncepta, ne bodo delovali. Če resno razmišljamo o povečevanju obsega SV s strateško rezervo, moramo imeti vzpostavljen sistem, ki bo živel in bo vsaj deloma periodično preizkušen.

Slovenska vojska ima trenutno 8319 pripadnikov, od teh je 7169 pripadnikov stalne sestave (v nadaljevanju StaS), preostalih 1150 pa je pripadnikov PPRS. Številke veljajo za december 2014 (http:// www.slovenskavojska.si/o-slovenski-vojski/). Skupni dovoljeni obseg SV je do 10.000 pripadnikov, vendar SV tega ne dosega zaradi vladnih kadrovskih omejitev in tudi zaradi razmer na trgu delovne sile in lastne nekonkurenčnosti. Največja dovoljena številka za stalno sestavo je 7600 pripadnikov in 1500 pripadnikov za PPRS, skupaj torej 9100 pripadnikov.

Manevrski del SV, torej del, ki je namenjen temu, da se spoprime z nasprotnikom na bojišču in ga premaga v oboroženem boju, obsega štiri pehotne polke s 700 pripadniki po formaciji, skupaj torej približno 2800 pripadnikov ${ }^{10}$. Preostali predstavljajo bojno podporo, zagotovitev delovanja in poveljevanje in kontrolo (PINK) ter vojaško izobraževanje in usposabljanje. Ameriški general Georg C. Marshall je v intervjuju leta 1956 izjavil, da »je čisto napačna predpostavka, da je pehoto lahko izuriti« (Bolger, 1999, str. 29). Bližinski boj z nasprotnikom je za pehotnega vojaka izjemno osebno in stresno početje. Manj kot ima družba teh vojakov, boljši morajo biti. Dobra pehota je posebej izbrana, dobro usposobljena in predvsem sposobna sprejemati hitre odločitve in dobre presoje v boju (Bolger, 1999, str. 31).

To bi morala biti najpomembnejša kakovostna razlika med naborniško in poklicno pehoto. Naborniki opravljajo svoje naloge, ker jih morajo, poklicni vojaki pa načeloma to želijo delati. Če naborniška vojska natančno sledi programom, ki imajo vsebine predpisane s številom ur, mora poklicna vojska slediti doseganju standardov. Njihovo urjenje je in mora biti težje, realnejše in boljše.

Ena izmed prednosti naborniške vojske je številčnost. Vendar kakovost ne more vedno nadomestiti količine. Ob tem se nam zastavi vprašanje, kolikšna je ta številka za SV.

Kot navaja Doktrina VSR RS, se je vsaj od časa turških vpadov do osamosvojitve samoobrambna sposobnost prebivalstva na Slovenskem večkrat potrdila kot koristna. Kratek zgodovinski pregled oboroženih sil Slovenskega naroda v zadnjih 100 letih nam pokaže:

1. Vojska generala Maistra, leta 1918, približno 12.000 pripadnikov (http://www. slovenskavojska.si/o-slovenski-vojski/zgodovina/).

2. Slovenska narodnoosvobodilna vojska in partizanski odredi (SNOV in PO), avgust 1944, približno 21.700 pripadnikov (http://www.slovenskavojska.si/oslovenski-vojski/zgodovina/), do konca vojne naj bi to število naraslo na okoli 35.000 (Guštin v Bebler, 2005, str. 59-95).

\footnotetext{
${ }^{10}$ Gre za spletne vire, ki se nikjer ne sklicujejo na uradne vire in jih zato ne navajam posebej. Žal vsi meni znani uradni viri, povezani s številčnim obsegom enot SV, nosijo oznako zaupnosti in jih zato na tem mestu ne morem navesti. Za potrebe članka sklepam, da so dostopni spletni viri vsaj približno točni.
} 
3. Slovensko domobranstvo (SD), približno 13.500 (ibid).

4. Mobilizirani v nemško vojsko, 1941-1945, približno $50.000{ }^{11}$.

5. Teritorialna obramba RS, junij 1991, približno 35.000 pripadnikov (http://www. slovenskavojska.si/o-slovenski-vojski/zgodovina/).

Ob tem je treba upoštevati, da je vojska generala Maistra delovala skoraj izključno V severnem in SV delu Slovenije, torej na nekaj manj kot polovici današnjega slovenskega ozemlja.

Slovensko domobranstvo ${ }^{12}$ je bilo omejeno na tako imenovano Ljubljansko pokrajino oziroma operacijsko cono Jadransko Primorje, torej spet na nekaj manj kot polovico slovenskega ozemlja. Šele slovenska narodnoosvobodilna vojska in partizanski odredi so delovali na praktično celotnem ozemlju Slovenije, pri čemer pa je v njihovem primeru treba razumeti, da je šlo za gverilsko vojsko. ${ }^{13} \mathrm{SNOV}$ in PO so bili organizirani v dva korpusa in eno operativno cono, vendar sta številčnost in tudi bojna moč partizanskega korpusa bolj ustrezali enakovredni zavezniški pehotni diviziji. To lahko vidimo, če primerjamo številčnost in strukturo 7. korpusa SNOV in 2. pehotne divizije ZDA. ${ }^{14}$ Hkrati je treba vedeti, da sta tako slovensko domobranstvo kot slovenska narodnoosvobodilna vojska zajemala svoje pripadnike iz istega kadrovskega bazena slovenskega naroda med letoma 1941 in 1945, kamor pa je očitno zelo učinkovito in organizirano posegala tudi nemška vojska.

TO je leta 1991 s svojo prostorsko strukturo uspešno pokrila celotno slovensko ozemlje in uspešno onemogočala $\mathrm{v}$ doktrini manevrsko naravnanega nasprotnika, ni pa bila namenjena manevrskemu bojevanju pri obrambi teritorija. Njen končni obseg je bil junija 1991 približno 35.000 pripadnikov. Temu je treba prišteti še približno 10.000 miličnikov.

Zgodovinsko gledano torej lahko govorimo o 35.000 pripadnikih oboroženih formacij kot o tisti sili, ki lahko učinkovito onemogoča nasprotnikove sile na ozemlju velikosti Republike Slovenije. Prav sposobnost onemogočanja oziroma oviranja je tisto, kar dela vojaško doktrino države odvračalno, saj tako nasprotniku preprečujemo, da bi uresničil svoje cilje, in povečujemo njegove stroške (materialne, kadrovske in finančne) (Posen, 1984, str. 14). To potrjuje predpostavke iz ReSDPRO (do 10.000) in Doktrine vojaške strateške rezerve (do 25.000), ki skupaj predstavljata oboroženo silo 35.000 pripadnikov.

" Podatki o tem, koliko ljudi je bilo mobiliziranih v nemško vojsko, se zelo razlikujejo glede na vir. Seničar v svojem diplomskem delu navaja številko 28.000 do leta 1943 samo za Štajersko, hkrati pa navaja kot končno številko 150.000, kar vključuje vse, ki so bili mobilizirani v vojaške in paravojaške formacije okupatorja. Moja ocena je torej približna in se nanaša samo na mobilizirane v nemško vojsko.

12 V prispevku uporabljam oznako slovensko domobranstvo kot splošen naziv za enote, ki so sodelovale z okupatorjem, saj so se njihovi nazivi in organiziranost med vojnimi leti precej spreminjali.

${ }_{13}$ Brigade SNOV so bile enote, namenjene manevrskemu bojevanju. Preostanek SNOV so bile tako imenovane prostorske sile.

${ }_{14}$ Partizanske čete so štele od 30 do 80 borcev, bataljoni od 100 do 250 in brigade od 300 do 800 borcev (Guštin $v$ Bebler, 2005, str. 59-95). Enote SNOV bi lahko kljub temu samo številčno primerjali z zavezniškimi enotami eno raven nižje, nikakor pa ne tudi po ognjeni moči, po kateri so bile enote SNOV še šibkejše. 
Ob tem je razmerje med stalno sestavo in predvidenim številom vojne sestave oziroma tako imenovano strateško rezervo bistveno. Za ilustracijo lahko pogledamo nemško vojsko, ki je bila po prvi svetovni vojni omejena na številko 100.000, kar ni ustrezalo obrambnim potrebam Nemčije, če bi se ponovila vojna v Evropi. S tem namenom si je nemški generalštab prizadeval čim hitreje povečati obseg. Tako so ustvarili vojsko vodij s konceptom poveljevanja, pri čemer se je skoraj od vseh pripadnikov vojske pričakovalo, da bodo lahko prevzeli poveljniške dolžnosti do dve ravni višje, kot so ga v resnici opravljali v strukturi 100.000 pripadnikov. To jim je, ko so bile razmere za to primerne, omogočilo hitro rast, ne da bi se pri tem poslabšala kakovost. Tako se je po letu 1935 število zelo hitro povečalo s 100.000 najprej na 300.000 in nato na 1.000.000 leta 1938. Težava je bila, da temu industrija ni bila sposobna slediti in da je politično vodstvo zahtevalo še hitrejšo rast, in sicer 4.000.000 leta 1939. To je nato privedlo do poslabšanja kakovosti oboroženih sil (Craig, 1964). Ta zgodovinska izkušnja kaže, da je hitro povečanje oboroženih sil sicer mogoče, a morajo biti za to izpolnjeni nekateri pogoji, kot so vgrajen presežek usposobljenih vodij, pripravljena infrastruktura in zagotovljena materialna baza. Po drugi strani pa ima hitra rast kljub izpolnjevanju vseh pogojev tudi svoje omejitve, ki se kažejo predvsem v rasti, ki bi bila večja od trikratne.

Če bi SV morala vzpostaviti vojni obseg okrog 35.000 pripadnikov, kar kažejo zgodovinske izkušnje in strateški dokumenti, njena stalna sestava ne sme biti manjša od 10.000, pri čemer pa mora izpolnjevati tudi vse prej navedene pogoje. Najpomembnejše pri tem je, da ima ustrezno število usposobljenih vodij za prevzemanje dolžnosti v vojaški strateški rezervi.

\section{KARAKTER SLOVENSKE VOJSKE}

Slovenska vojska je z zadnjo transformacijo dobila novo strukturo, ki kaže pretežno pehotno organizacijo. Bojna moč SV temelji na štirih pehotnih polkih, ki imajo znotraj brigad na voljo še več bojnih »multiplikatorjev $\aleph^{15}$. Z njihovo pomočjo je vsaka izmed pehotnih brigad, vsaj v teoriji, sposobna oblikovati bataljonsko bojno skupino za potrebe zavezništva. Kakršna koli že je ali bo struktura SV v prihodnje, je dejstvo, da njena bojna moč temelji na pehotnih enotah ranga bataljona oziroma brigade. Vprašanje pa je, kakšno vrsto pehote naj bi te enote imele.

Zavezništvo pozna več različnih tipov pehote, od mehanizirane, motorizirane, mornariške, zračnodesantne, zračnopremične do gorske. Doktrinarno pojma lahka pehota zavezništvo ne pozna. Poznajo pa posamezne države zavezništva še druge specializirane tipe, kot so na primer ameriški rangerji, ki jih lahko obravnavamo kot lahko pehoto.

Če prepoznamo pehoto kot temelj bojne moči SV, se moramo vprašati tudi, kakšen tip pehote bi ustrezal obrambnim potrebam Republike Slovenije. V preteklosti so se

\footnotetext{
${ }_{15}$ To so enote bojne podpore, ki so v teoriji sicer res na voljo polkom, vendar o tem, kaj, če sploh kaj, dobijo polki, odloča izključno njihov poveljnik.
} 
pojavljale različne zamisli, od zračnodesantne pehote do zračnopremične in ranger bataljonov. Ideje so sicer zanimive in za marsikoga zelo privlačne, vendar menim, da se moramo najprej vprašati, čemu je posamezen tip pehote sploh namenjen, kakšne so njegove odlike in pomanjkljivosti ter kako se SV namerava bojevati z nasprotnikom ${ }^{16}$.

Naloge SV so zelo široke, od zaščite in reševanja do obrambe pred zunanjim napadalcem. Ni tipa pehote, ki bi idealno ustrezal vsem tem nalogam, menim pa, da moramo izhajati iz najbolj zahtevne naloge, torej izvajanja vojaške obrambe, in nato ugotoviti, kako to pehoto uporabiti tudi za druge naloge.

Zračnodesantna pehota: ima zelo specifično vlogo strateške projekcije vojaške sile ${ }^{17}$ na razdaljah, ki so zunaj dosega običajnih transportnih sredstev (prim. Granada). Kot taka je najboljša, ko skoči neposredno na nasprotnika, saj je najboljša prav v elementu presenečenja. Ko pa enkrat opravi z nasprotnikom na cilju, je zelo ranljiva (prim. Arnhem v drugi svetovni vojni). Primanjkuje ji mobilnosti (razen strateške), poleg tega pa je vzdrževanje ustrezne pripravljenosti teh enot zelo drago.

Zračnopremična pehota: je najbolj mobilna med vsemi tipi pehote (CC\&CS, 2011, str. A-104). Tako kot zračnodesantna pehota tudi zračnopremična zahteva specializirano urjenje, kajti ne gre le za to, da bi katero koli pehoto vkrcali v helikopterje in jo na določeni točki odložili. Njena moč je v sodelovanju pehote $\mathrm{z}$ letalstvom, a je hkrati to tudi njena največja ranljivost. Helikopterji niso oklepniki in ni treba veliko, da jih sestrelijo. ${ }^{18}$ Padec helikopterja pa je navadno usoden tako za posadko kot potnike. Zračnopremična pehota je močna le, ko in če sodelujejo pehota, artilerija in letalstvo (bojni helikopterji in letala). Helikopterji, predvsem bojni, tudi precej stanejo, ne le nakup, temveč tudi vzdrževanje njihovih zmogljivosti.

Mehanizirana pehota: omogoča napredovanje tankom, kadar zaradi terena ali nasprotnika to ni izvedljivo. Mehanizirana pehota se izkrca le, kadar je to nujno, sicer pa taktične naloge rešuje s svojimi vozili, s katerimi prikuje nasprotnikovo pehoto in omogoči napredovanje svojim tankom. Tako se za mehanizirano pehoto v zavezništvu predpostavlja, da je opremljena z vozili z najmanj 20-milimetrskim topom. ${ }^{19}$ Le ta orožja se namreč lahko bojujejo skupaj s tankovskim topom. Iz tega izhaja, da je mehanizirana pehota smiselna, če obstajajo tudi tankovske zmogljivosti. Samo pri skupnem bojevanju, pri katerem imajo tanki vodilno vlogo, lahko prednosti mehanizirane pehote povsem izkoristimo. Ne smemo namreč pozabiti, da so izkrcni elementi mehanizirane pehote navadno zelo majhni, manjši od lahke,

\footnotetext{
${ }^{16}$ Menim, da sem v članku že pokazal, da je normativna vojaška doktrina RS odvračalna in da je za države, kot je Slovenija, tudi edina mogoča.

${ }_{17}$ CC \& CS, 2011, str. A-104, točka 1.1.

18 Njena poglavitna omejitev je zaščita lastnih sil (CC \& CS, 2011, str. A-104, točka 2.9).

${ }^{19}$ NATO BI-SC Agreed Capability Codes and Capability Statements iz leta 2011 sicer ne opredeljuje eksplicitne zahteve za najmanj 20-milimetrski top v mehanizirani pehoti, vendar pa ta izhaja iz zahteve, da je mehanizirana pehota »sposobna podpore oklepnih enot« (str. A-103, točka 2.10). Drugi ustrezni viri zavezništva imajo oznako zaupnosti in jih kot take $v$ tem prispevku ne morem uporabiti.
} 
zračnodesantne in zračnopremične pehote ter se tako hitro iztrošijo. Oklepne enote so sicer v manevru najbolj učinkovite in najhitrejše, toda bojujejo se lahko le kot del celote $\mathrm{v}$ združenem bojevanju rodov. Kdor torej gradi mehanizirano pehoto, mora imeti tudi vse druge elemente - ustrezne oklepne enote, artilerijo, ki to podpira, in prevlado v zraku. Mehanizirana pehota se lahko bojuje tudi samostojno, brez tankov, in je v tem lahko zelo učinkovita, vendar to ni njen glavni namen. Pri vsem tem pa tako tanki kot bojna vozila pehote tudi precej stanejo, ne le njihova nabava, temveč tudi vzdrževanje zmogljivosti.

Motorizirana pehota: njena glavna odlika je prilagodljivost (Bolger, 1999, str. 259). Odlična je na težje prehodnem terenu (gore, gozd, močvirja, urbana naselja), ponoči in v slabih vremenskih razmerah. Njena glavna pomanjkljivost je, da je v premiku oziroma manevru vezana na noge oziroma motorizirana transportna sredstva ${ }^{20}$. Nima zaščite oklepa, razen, če je opremljena z oklepnimi transporterji. Treba pa je razumeti, da so oklepni transporterji le to, torej transportna vozila. Motorizirana pehota se bojuje brez vozil in je omejena v ognjeni moči, mobilnosti in zaščiti (CC\&CS, 2011, str. A-103). Bremena tovrstnega bojevanja na vojaka so ogromna tako v fizičnem kot psihičnem smislu.

Mornariška pehota: je podobno kot zračnodesantna namenjena strateški projekciji sile. Ker je vezana na ladijski transport, je precej počasnejša, ima pa zato veliko več ognjene moči in daljšo samozadostnost (15 dni na kopnem, na morju v regiji 6 mesecev - taki so podatki za mornariško pehoto ZDA). Mornariška pehota ima na voljo še lastno ladijsko in zračno podporo (CC \& CS, 2011, str. A-91, A-92).

Gorska pehota: je pehota, ki je s svojo usposobljenostjo in opremo specifično prilagojena delovanju v gorskem oziroma arktičnem svetu (CC \&CS, 2011, str. A-103, A-104). V primerjavi z motorizirano pehoto se gorska pehota za svoj premik naslanja bolj na helikopterske kot motorizirane zmogljivosti. Bojevanje v gorskem in arktičnem svetu poleg bojevanja pomeni velik fizični napor, zato je ustrezna selekcija za gorsko pehoto nujna.

Ranger pehota: je sicer del kopenske vojske ZDA, toda ta tip visoko usposobljene pehote najdemo tudi $\mathrm{v}$ drugih oboroženih silah. Rangerji so pehota, zelo dobro usposobljena, vodena in opremljena, pa vendarle samo pehota. V vojski ZDA so ranger bataljoni specializirani za zavzemanje letališč in v tem ni boljših. V specialnih silah ZDA, s katerimi večinoma sodelujejo, pa imajo primarno dve nalogi: sile za hitro posredovanje oziroma tako imenovani QRF in sile za naskok oziroma tako imenovani »raid« (Bolger, 1999, str. 191). Rangerji na bataljonski ravni ne poznajo izvidnikov in minometov, ker niso namenjeni dolgotrajnejšim bojnim operacijam, temveč bliskovitim neposrednim akcijam (Bolger, 1999, str. 212). Rangerji so pehotna elita, ki od svojih mož pričakuje najboljše in ima temu ustrezen selekcijski sistem. Standardi izvedbe osnov so odlični, za kar pa imajo tudi ustrezne pogoje - dovolj streliva za urjenje in časa (neobremenjenost s stražarsko službo in garnizonskimi dolžnostmi).

${ }^{20}$ To so lahko tovornjaki, oklepni transporterji $(4 \times 4,6 \times 6,8 \times 8)$ ali v skrajnosti kakršna koli druga vozila. 
Neodvisno od tipa mora biti sodobna, poklicna in mala pehota odlična $\mathrm{v}$ treh temeljnih prvinah: v fizični pripravljenosti, strelski izurjenosti in taktiki malih enot (Bolger, 1999, str. 234).

Vojaška doktrina SV na deklarativni ravni je torej odvračalna. Kot pa smo ugotavljali že v uvodu, je SV kopenska vojska s pehoto kot njenim osrednjim elementom bojne moči. Kakšna pehota torej ustreza tej doktrini? Takoj lahko izključimo zračnodesantno in mornariško pehoto, saj sta to tipa pehote, ki sta namenjena predvsem strateški projekciji sile in ofenzivni doktrini. Kljub temu to ni vzrok, da posamezne zmogljivosti SV ne bi imele teh sposobnosti. Tu gre predvsem za specialne sile, ki zaradi narave svojega dela vsekakor potrebujejo zračnodesantne zmogljivosti. Poleg tega bi veljalo proučiti tudi formacijo različnih mornariških pehotnih formacij, v smislu dobrih lekcij na področju obsega, oborožitve in ognjene moči.

Prav tako odpade tako imenovana ranger pehota, saj je visoko specializirana in ni namenjena dolgotrajnejšim bojnim operacijam, ki jih predpostavlja odvračalna doktrina. Bi pa veljalo proučiti njihove selekcijske postopke v smislu dvigovanja »esprit de corps«.

Zračnopremična pehota je zelo mobilna, a je hkrati tudi zelo draga. Bojni in transportni helikopterji so zapleteni in zelo dragi oborožitveni sistemi. Toda brez enih in drugih prave zračnopremične pehote ni. Poleg tega so to sistemi, ki so izrazito ofenzivni in namenjeni globokim prodorom oziroma preskakovanju nasprotnika, ne pa kontroli ozemlja.

Slovenska vojska postopoma umika tankovske zmogljivosti iz uporabe. Do izteka življenjske dobe bo zadržala le zmogljivost ene tankovske čete. Vsi preostali tanki in bojna vozila pehote bodo umaknjeni v strateško rezervo (MORS-SOPR, 2012, str. 39), zato je težko razumljiv argument, da SV potrebuje mehanizirano bataljonsko bojno skupino zaradi lastnega razvoja. Brez tankovske zmogljivosti tudi zmogljivost mehanizirane pehote v SV nima smisla, razen v luči izpolnjevanja zavez do zavezništva. Zavezništvo ima tankovske zmogljivosti in potrebuje mehanizirane zmogljivosti v svoji podpori. SV tako sicer lahko razvija mehanizirano zmogljivost, da bi prek nje dosegala večjo povezljivost v zavezništvo, vendar menim, da bi to lahko dosegala tudi na druge, finančno manj obremenjujoče načine - tudi zmogljivosti motorizirane pehote morajo biti povezljive $\mathrm{v}$ zavezništvo, prek informacijske tehnologije, postopkov in procedur, oborožitvenih zmogljivosti in sistema PINK. Največja težava vsakršnega koalicijskega delovanja je vedno vprašanje PINK (Posen, 1984, str. 81).

Na prvi pogled se gorska pehota zdi idealna za potrebe RS in SV. Dejstvo pa je, da visokogorje pokriva le slabo četrtino slovenskega ozemlja. Preostanek predstavljajo sredogorje, gričevje in ravnina. SV ima tudi jasno izražene ambicije z vzpostavitvijo Natovega centra odličnosti v gorskem bojevanju. Toda gorska pehota je premalo prilagodljiva, da bi predstavljala osnovo bojne moči SV. 
Tako ostane še motorizirana pehota. Njena glavna odlika je prav velika prilagodljivost. Na prvi pogled se sicer zdi, da je motorizirana pehota hkrati tudi najcenejša. Morda je res cenejša od večine drugih tipov pehote, a še zdaleč ni poceni. Motorizirana vozila, pa naj bodo to tovornjaki ali oklepni transporterji, niso poceni sistemi. Poleg tega mora motorizirana pehota svoje omejitve v mobilnosti, ognjeni moči in zaščiti nekako nadomestiti. Potrebuje več protioklepnih sredstev, več lažjih minometov in drugega podpornega orožja, poleg tega pa mora biti tudi na področju PINK povezljiva v sisteme zavezništva. Je pa motorizirana pehota tudi zaradi svoje številčnosti in transportnih sredstev še najprimernejša za sodelovanje v sistemu ZiR, kar se je pokazalo tudi ob zadnjih velikih naravnih nesrečah v RS, ob žledu in poplavah.

Sklep Kratek zgodovinski pregled in strateški dokumenti kažejo, da bi morala SV imeti možnost večanja svojega obsega na okrog 35.000 pripadnikov. Hkrati s predlaganim maksimalnim obsegom SV odvračalna vojaška doktrina, širok zakonski nabor nalog in omejena finančna sredstva kažejo na to, da bi morali bojno jedro SV sestavljati motorizirana in lahka pehota.

Seveda bi bilo nesmiselno vzdrževati stalno sestavo v končnem obsegu 35.000, mora pa imeti SV vse sistemske nastavke, da bi lahko ob izraženi potrebi brez večjih naporov narasla do tega obsega. Doktrina VSR RS predvideva le sistemske nastavke, brez pripravljenih načrtov in z malo večinoma prostovoljno usposobljenega kadra. SV hkrati daje eno leto, da se njen obseg poveča za do 25.000 pripadnikov. Ob tem pa se pojavljajo zahteve po še dodatnem zmanjševanju trenutnega obsega SV. Menimo, da slednje ne morejo vzdržati trezne strokovne presoje, razen če ne spremenimo zakonsko opredeljenih nalog SV v smislu zavestne odpovedi učinkovitemu oboroženemu odporu v primeru ogrožanja nacionalne suverenosti. Hkrati menimo, da tudi konceptualne rešitve, ki jih predvideva Doktrina VSR RS, ne bodo vzdržale resnega preizkusa. SV in tudi preostanek obrambnega sistema RS V trenutnem stanju nikakor nista sposobna v enem letu iz trenutnega stanja vzpostaviti sistema, katerega končni rezultat bi bil 35.000 za boj usposobljenih pripadnikov, razporejenih v ustrezne formacije. Nemogoče je tudi pričakovati, da bi SV lahko v trenutnih finančnih in političnih razmerah kakor koli povečevala svoj mirnodobni obseg.

Rešitve bi se morale poiskati nekje vmes. SV bi morala imeti pripravljene načrte uporabe VSR in pripravljene formacije enot $\mathrm{VSR}^{21}$. To bi njej in preostanku obrambnega sistema omogočalo materialno in kadrovsko načrtovanje. To SV tudi praktično nič ne stane, razen delovnih ur štabnih častnikov in uradnikov MO RS, ki morajo te načrte in formacije pripraviti. ${ }^{22}$

\footnotetext{
${ }^{21}$ Skladno z ZoObr bi to predstavljalo vojno formacijo $S V$.

22 VSR bi morala obstajati kot vojna formacija, brez statusnih in plačilnih ugodnosti mirnodobnih formacij. Nanje ne sme biti mogoče predhodno postavljati pripadnikov StaS, ne, dokler ne pride do odločitve o aktiviranju VSR. Pripravljeni morajo biti načrti o popolnjevanju vojnih formacij s pripadniki StaS. V nasprotnem primeru se bo koncept izrodil, kot smo to v preteklosti že poznali in bi se VSR uporabljala za reševanje karier posameznikov. To pa bi bilo kontraproduktivno.
} 
V tem okviru je potreben tudi razmislek o strukturi in namenu PPRS. S PPRS bi lahko zagotovili del najpomembnejšega poveljniškega kadra za VSR.

Bistven je vojaški izobraževalni sistem, ki mora omogočiti trikratno rast mirnodobne strukture SV. To ne pomeni, da mora biti tako obsežen, temveč, da mora $\mathrm{z}$ izobraževanjem in usposabljanjem pripraviti poveljujoči kader mirnodobne sestave na prevzemanje višjih dolžnosti v VSR. ${ }^{23}$

Veljalo bi tudi razmisliti o tem, kako zagotoviti ustreznejše število usposobljenih posameznikov za VSR. Rast z 10.000 do 35.000 brez vnaprej pripravljenih jasno opredeljenih in preizkušenih načrtov ter formacij je nerealen. Nerealen je v 365 dneh, če bi jih bilo sploh toliko na voljo, o čemer pa ob sodobnem tempu razvoja kriznih situacij močno dvomim. Očitno je, da zanašanje na tiste, ki so prostovoljno odslužili vojaški rok, ne bo dovolj. Najlažja bi bila seveda ponovna uvedba neke oblike državljanske obveznosti, ki bi državljanom dala temeljno vojaško znanje, potrebno za hitro vzpostavitev VSR, mogoče v krajši obliki, kot smo jo poznali (do 3 mesece), in ki bi bila dopolnjena $\mathrm{z}$ vsebinami ZiR. ${ }^{24}$ Toda ker je to malo verjetno, bi morali razmisliti o drugih možnostih, kot je uvajanje obrambnih oziroma vojaških vsebin med obvezne vsebine v srednjih šolah in morda celo na fakultetah.

Ob tem mora SV zadržati vsaj trenutni, z ReSDPRO dovoljeni mirnodobni obseg do 10.000 pripadnikov. Vsako zmanjševanje pod ta obseg bo onemogočalo realnoizvedbo ideje o rasti VSR za do 25.000 pripadnikov. Preprosto bo to fizično neizvedljivo V času, ki bi bil lahko na voljo. Ob tem bo treba izvesti ukrepe za pridobivanje kadra za zapolnitev mest v StaS, kar pa bo s seboj nujno prineslo neželene finančne posledice. Varnost pač stane in v nasprotju s krilatico, da se z manj lahko naredi več, so meje, prek katerih je manj pač samo še manj.

Bojno jedro mirnodobne sestave SV bi torej morala sestavljati motorizirana pehota, bojno jedro vojne sestave (obseg 35.000) pa kombinacija motorizirane in lahke pehote (motorizirana v delu, ki bi izvajal manevrsko vojskovanje ${ }^{25}$, in lahka v delu, ki bi pokrival prostor ${ }^{26}$ ).

Motorizirana pehota je dovolj prilagodljiva, da bi lahko izpolnjevala vse zakonsko zastavljene naloge, hkrati pa bi bila finančno vzdržljiva. To, kar Slovenija prispeva v zavezništvo, je vedno stvar pogajanj in bi moralo v prvi vrsti odražati njeno

${ }^{23}$ Poveljniki vodov bi morali imeti znanje za vodenje čete VSR in delo na najpomembnejših štabnih dolžnostih VSR. Poveljniki čet bi morali vedeti, kako voditi bataljone, polke VSR itn.

${ }^{24}$ Taka oblika naborništva ne bi dala bojno uporabnih enot, bi pa zagotovila za ravnanje z orožjem usposobljene posameznike s temeljnim taktičnim znanjem na ravni oddelka, morda tudi voda. Hkrati bi omogočala državljanom aktivnejšo udeležbo v aktivnostih ZiR.

${ }^{25}$ Premestljive in nepremestljive sile v visoki in nizki stopnji pripravljenosti. Oblikovanje teh mora omogočati mirnodobna formacija, pri čemer StaS oblikuje premestljive sile za delovanje v okviru zavezništva (bataljonske bojne skupine in drugi cilji zmogljivosti Nata za SV), kombinacija StaS in PPRS pa omogoča oblikovanje sil za delovanje doma (dve brigadni bojni skupini).

${ }^{26}$ Nepremestljive sile z daljšim časom vzpostavitve pripravljenosti glede na Vojaško doktrino SV. Te sile bi predstavljala VSR. 
odvračalno vojaško doktrino. Izpolnjevanje zavez do zavezništva je pomembno in vpliva na kredibilnost države v mednarodnem okolju. Slovenija mora dati tudi sorazmerni prispevek k skupni varnosti, ki jo zavezništvo daje. Prevečkrat se $\mathrm{v}$ javnosti pojavljajo samo negativne strani članstva $\mathrm{v}$ zavezništvu, hkrati pa se pozablja, da na primer Republika Slovenija z instrumenti zavezništva brez velikih stroškov varuje svoj zračni prostor, uporablja vadišča in strelišča zavezništva, kakršnih sama nima, itn.

Sodobna motorizirana pehota ni poceni sistem. Morda ima kdo v mislih slabo opremljeno in nekakovostno izurjeno oboroženo silo, kar pa ne bi moglo biti dlje od resnice. Sodobna motorizirana pehota je dobro opremljena in dobro usposobljena vojaška sila, ki ima sicer omejitve v mobilnosti, ognjeni moči in zaščiti, a ima tudi sisteme, urjenje in poveljniški kader, ki lahko te pomanjkljivosti nevtralizirajo. Največja odlika motorizirane, pa tudi lahke pehote, je njena prilagodljivost.

Javnofinančna stvarnost je neusmiljena in ob predvidenih trendih virov za potrebe SV se moramo vprašati, kako naprej. Vztrajanje na številkah, ki jih finance ne dovoljujejo, je lahko samo kontraproduktivno. Minimum, pod katerega SV ne sme iti, je sledenje ciljem zmogljivosti, dogovorjenih z zavezništvom. Mogoče bi lahko katerega izmed ciljev zmogljivosti tudi spremenili skozi procese obrambnega načrtovanja zavezništva. Izpolnjevanje ciljev zmogljivosti hkrati z izpolnjevanjem obvez do zavezništva pomeni tudi zadrževanje minimalnega strokovnega znanja in vsaj okostja strukture SV. Ne omogoča pa izpolnjevanje vseh zakonsko določenih nalog SV in močno omejuje celo sodelovanje v sistemu ZiR. Cilji zmogljivosti številčno predstavljajo približno $4100^{27}$ pripadnikov StaS, vendar tudi ti sami zase ne morejo obstajati. Tudi zanje so potrebni zunanji elementi zagotovitve delovanja (vzdrževanje, oskrba, transport itn.), infrastrukture, izobraževanja in usposabljanja ter PINK (tudi PINK z zavezništvom). Ko bi prišteli to, kar je nujno za vzpostavitev CZ, bi verjetno prišli do približno 6500 pripadnikov StaS. A to je lahko le začasna rešitev, ki premošča slabo finančno stanje in v resnici verjetno ne prinaša toliko finančnih koristi, kot povzroča nacionalnovarnostne škode. Bi pa omogočila prenos dela finančnih sredstev iz postavke osebni prejemki pripadnikov na postavke modernizacije in tako zagnala razvoj $\mathrm{CZ}$.

Ob tem se je treba zavedati tudi, kakšna so priporočila zavezništva, povezana s premestljivostjo, visoko stopnjo pripravljenosti in vzdržljivost. Priporočila zavezništva so, da imajo oborožene sile 50 odstotkov premestljivih sil, 10 odstotkov $\mathrm{v}$ visoki stopnji pripravljenosti doma in 0,8 odstotka vzdržljivih. Glede na to, da vse zmogljivosti CZ spadajo med premestljive sile, bi glede na priporočila zavezništva končni obseg SV ne smel biti manjši od okoli 8200 pripadnikov.

\footnotetext{
${ }^{27}$ Gre za spletne vire, ki se nikjer ne sklicujejo na uradne vire in jih zato ne navajam posebej. Žal vsi meni znani uradni viri, povezani z obsegom CZ, nosijo oznako zaupnosti in jih zato ne morem navesti. Za potrebe članka sklepam, da so dostopni spletni viri vsaj približno točni.
} 
SV bi v vsakem primeru morala imeti pripravljene načrte in formacije za strukturo 10.000 StaS ter politična zagotovila za načrte rasti in popolnjevanja formacij, takoj ko bi javnofinančni položaj to dovoljeval.

$\mathrm{Ob}$ tem se mora postaviti jasna prioriteta popolnjenosti enot, ki uresničujejo $\mathrm{CZ}$ in izpolnjujejo zaveze do zavezništva. Preostanek StaS je namenjen najprej vzpostavitvi dveh manevrskih brigad lahke pehote $\mathrm{z}$ vsemi potrebnimi bojnimi multiplikatorji in nato vzpostavitvi VSR v primeru njenega aktiviranja.

SV mora torej odločno in argumentirano nastopiti proti vsakršnim poskusom zmanjševanja njenega trenutnega obsega, hkrati pa aktivno spodbujati javno razpravo o njenem namenu, obsegu, značaju in strukturi. Za potrebe te razprave se mora tudi notranje poenotiti in pripraviti strokovno utemeljene argumente, ki jih bo zagovarjala. Končni rezultat še vedno utegne biti za SV negativen in v tem primeru bomo njeni pripadniki morali tudi tovrstne končne odločitve sprejeti in iz njih iztisniti največ, kar se bo dalo. Ne smemo pa dopustiti, da bi se kakršne koli odločitve o zmanjšanju obsega sprejemale brez jasno slišanih in sprejetih argumentov SV.

\section{Literatura}

1. Bebler, A., 2005. Sodobno vojaštvo in družba. Ljubljana: FDV.

2. Bolger, D. P., 1999. Death Ground - Today's American Infantry in Battle. Random House Publishiing Group.

3. Craig, G. A., 1964. The Politics of the Prussian Army 1640-1945. London: Oxford University Press.

4. Declaration Issued by the Heads of State and Government participating in the meeting of the North Atlantic Council in Wales, Press Release (2014) 120, Issued on 05 Sep. 2014 Last updated: 16.92014.

5. Državni zbor RS, 2010. Resolucija o strategiji nacionalne varnosti Republike Slovenije (ReSVN-1). Ljubljana: MORS.

6. Državni zbor RS, 2010. Resolucija o splošnem dolgoročnem programu razvoja in opremljanja Slovenske vojske do leta 2025 (ReSDPRO SV 2025). Ljubljana: MORS.

7. Furlan, B. (et al), 2006. Vojaška doktrina. Ljubljana: Defensor d.o.o.

8. Grizold, A. 2005. SLOVENIJA V SPREMENJENEM VARNOSTNEM OKOLJU, K razvoju obrambno zaščitnega sistema: Izzivi in spodbude. Ljubljana, FDV.

9. Kuster, J., 1979. Spominski zbornik ob 60-letnici bojev za severno slovensko mejo 19181919. Maribor: ZGEP Pomurski tisk.

10. Moscos, C.C., 2000. The Postmodern Military. New York: Oxford University Press.

11. MORS, 2012. Doktrina vojaške strateške rezerve RS. Ljubljana: MORS.

12. MORS, 2009. Strateški pregled obrambnega resorja 2009. Ljubljana: MORS.

13. NATO, 2010. AJP-01(D) Alied Joint Doctrine. NATO Stardandisation Agency.

14. NATO, 2011. Bi-Sc Agreed Capability Codes and Capability Statements. Belgium: Supreme Allied Commander, Europe.

15. Posen, B. R., 1984. The Sources of military doctrine-France, Britain, and Germany Between the World Wars. Beograd 1992: Vojnoizdavački i Novinski centar.

16. Seničar, M., 2006. Slovenski fantje v vojski tretjega rajha-diplomsko delo. Ljubljana: FDV.

17. Severnoatlantska pogodba na http://nato.gov.si/slo/dokumenti/severnoatlantska-pogodba, 13. 1. 2015. 
18. The North Atlantic Treaty na http://www.nato.int/nato_static/assets/pdf/stock publications/20120822_nato_treaty_en_light_2009.pdjf, 13. 1. 2015.

19. The Wales Declaration on the Transatlantic Bond, Press Release (2014) 122, Issued on 05 Sep. 2014, 10. 9. 2014.

20. Vlada RS, 2012. Obrambna strategija Republike Slovenije. Ljubljana: št. 80000-1/2012/4, 7. 12.2012.

21. Vlada RS, 2013. Srednjeročni obrambni program Republike Slovenije 2013-2018. Ljubljana: št. 80300-1/2013/3 z dne 1. 2. 2013. http://youtu.be/tEHYGFWO7pQ http:// www.slovenskavojska.si/o-slovenski-vojski/.

22. Vlada RS, 2004. Zakon o obrambi (uradno prečiščeno besedilo). Ljubljana: ULRS.

23. O Slovenski vojski, http://www.slovenskavojska.si/o-slovenski-vojski/zgodovina, 13. 1. 2015.

24. http://youtu.be/tEHYGFWO7pQ, 13. 1. 2015. 


\title{
VOJAŠKOMEDICINSKA OBVEŠČEVALNA DEJAVNOST Z OMEJENIMI VIRI NA PRIMERU MAJHNIH DRŽAV
}

\author{
MILITARY MEDICAL INTELLIGENCE WITH LIMITED \\ RESOURCES IN THE CASE OF SMALL COUNTRIES
}

Povzetek Slovenska vojska poleg nacionalne obrambe opravlja naloge v mednarodnih operacijah in na misijah v zahtevnih podnebnih in geografskih razmerah zunaj območja držav članic Nata in EU. Zavezniške sile, ki opravljajo svoje poslanstvo na ozemljih zunaj Natovega območja, so lahko izpostavljene različnim dejavnikom tveganja, ki vplivajo na njihovo zdravje. Za njihovo ustrezno zdravstveno zaščito je treba sprejeti in izvajati učinkovit program, ki naj bo namenjen tako zdravstvenemu osebju kot poveljnikom. Strokovno zdravstveno osebje pridobiva zdravstvene podatke, na primer ocenjuje okoljske in zdravstvene vire ogrožanja, prepozna tveganja in izdela analizo groženj, ter jih vključuje v upravljanje tveganj. MEDINT ima pomembno vlogo $\mathrm{v}$ razmerju med zdravstvenim sistemom in krovno obveščevalno dejavnostjo, uporablja zakonitosti njenega obveščevalnega ciklusa, saj se na nekaterih stopnjah obveščevalni ciklus MEDINT vključuje v obveščevalni ciklus krovne obveščevalne dejavnosti. Končni obveščevalni proizvod MEDINT, ki temelji na oceni zdravstvene ogroženosti, podpira poveljnikov namen in operacijo.

Ključne MEDINT, obveščevalna dejavnost, vrednotenje medicinsko-geografskega prostora, besede Slovenska vojska.

Abstract In addition to providing for national defence, the Slovenian Armed Forces perform tasks in demanding climatic and geographical conditions in international operations and missions outside the territory of NATO and EU Member States. Allied forces performing their mission in the territories outside the NATO area may be exposed to various threats that affect their health. For the protection of the forces' health, it is necessary to adopt and implement an effective program, which should be aimed, both, at healthcare personnel as well as commanders. Professional medical staff obtains medical data, assesses environmental and medical threats, identifies the risks, carries 
out threat analysis and implements them in risk management. Medical intelligence (MEDINT) plays an important role in the relation between the health system and intelligence activities. It also uses the intelligence cycle to ensure that all available information for making assessments is processed. To be fully efficient MEDINT requires the cooperation of experts from different natural science disciplines (medical, scientific or bio-engineering). The final MEDINT product based on the health threat assessment supports the commander's intent and the operation as such.

Key words MEDINT, intelligence, evaluation of medico-geographical environment, Slovenian Armed Forces.

Uvod Vojaška zgodovina nas uči, da so se mnoge bitke končale z velikimi izgubami vojakov, predvsem zaradi nepoznavanja nalezljivih bolezni, nepravilne zdravstvene zaščite sile in nepoznavanja škodljivih vplivov okolja na območju delovanja. Slovenska vojska (SV) kot obrambna sila Republike Slovenije je med operacijami kriznega odzivanja na geografskem območju, ki ni del ozemlja članic Nata, izpostavljena različnim dejavnikom tveganja za zdravje.

»Vnaprejšnja informacija omogoča modrim vladarjem in uglednim generalom, da napredujejo in osvajajo, prinese jim uspeh, ki jim ga številčnost ne more."

(Sunzi, 2009, str. 145)

Za zagotavljanje zdravstvene zaščite sile ima zelo pomembno vlogo medicinska obveščevalna dejavnost (Medical Intelligence - MEDINT), ki je v strukturi podzvrst krovne obveščevalne dejavnosti. V MEDINT sodelujejo strokovnjaki s področja naravoslovnih znanosti, ki pridobivajo medicinske, bioznanstvene, epidemiološke in okoljske podatke, pomembne za zdravje ljudi in živali.

Slovenska vojska sodeluje $\mathrm{v}$ mednarodnih operacijah in na misijah (MOM) tudi v okoljih, ki so z medicinskega in geoprostorskega vidika slabo poznana. Naloga MEDINT je pridobivanje podatkov o zdravstvenih in okoljskih nevarnostih ter o zdravstvenih zmogljivostih in sposobnostih na območju delovanja. Pri pripravi načrta za zagotavljanje zdravstvene zaščite sile sta nujni civilno-vojaško in interdisciplinarno sodelovanje.

Predstavljena sta struktura in delovanje vojaškega zdravstva, prav tako je podan predlog modela MEDINT v SV, v katerem sta opredeljena uporabniško osredotočen model obveščevalnega procesa ter vključitev MEDINT v obveščevalni ciklus osrednje obveščevalne dejavnosti. Menimo, da je pri pripravi pripadnikov, ki sodelujejo v vojaških operacijah ekspedicijskega značaja, vloga MEDINT zelo pomembna. Pri tem ne gre samo za pridobivanje podatkov o zdravstveni ogroženosti sil, temveč za celovito pripravo pripadnikov, ki vključuje tudi pridobivanje podatkov o političnih, vojaških, ekonomskih, socialnih značilnostih ter infrastrukturi in 
informacijskem sistemu (PMESII) ${ }^{1}$. Prav tako je naloga MEDINT pridobivanje in analiziranje podatkov o geografskih, podnebnih in demografskih značilnostih z območij kriznega odzivanja.

Majhne države so na področjih obrambe in za zagotavljanje svoje varnosti razvile različne postopke. Odločitve, ki jih sprejemajo o nacionalni varnosti, zelo pogosto temeljijo na predhodnih izkušnjah. Zavedati se moramo, da majhnost države ne pomeni tudi njene šibkosti in da majhne države svojo »moč« uporabljajo drugače kot velike, saj jo izkazujejo kakovostno in ne količinsko (Mikuž, 2012). Značilnost majhnih držav je krepitev moči na različnih področjih, ki so za vsako državo zelo posebna. Pogosto se te države zaradi zmanjšanih zmogljivosti in sposobnosti na področju obrambe in varnosti povezujejo $\mathrm{z}$ drugimi državami $\mathrm{v}$ zavezništvo ali pa se odločijo za nevtralnost. Danes se v mednarodnem varnostnem okolju podpira večnacionalni razvoj zmogljivosti.

\section{POSLANSTVO IN NALOGE SLOVENSKE VOJSKE}

Zakon o obrambi (ZObr) določa poslanstvo in naloge SV. Slovenska vojska je bila leta 1994 v Zakonu o obrambi prvič imenovana kot obrambna sila RS. Nastala je iz takratne Teritorialne obrambe, katere naloge so bile omejene na nacionalno ozemlje. Danes SV poleg skrbi za nacionalno varnost opravlja naloge v mednarodnih operacijah in na misijah na kriznih žariščih zunaj geografskega območja zavezništva. Namen SV je z vojaškimi zmogljivostmi prispevati $\mathrm{k}$ uresničevanju interesov in nacionalnovarnostnih ciljev RS. Njeno poslanstvo je zagotavljati obrambne sposobnosti in izvajati vojaško obrambo Republike Slovenije, vojaško prispevati $\mathrm{k}$ mednarodnemu miru, varnosti in stabilnosti, sodelovati v sistemu varstva pred naravnimi in drugimi nesrečami ter podpirati druge državne organe in organizacije pri zagotavljanju varnosti.

Glavne naloge SV, ki izhajajo iz njenega poslanstva, so vzpostavitev načrtovanih zmogljivosti in vzdrževanje ustrezne stopnje njihove pripravljenosti, izvajanje nacionalne vojaške obrambe in izpolnjevanje mednarodnih vojaških zavez na podlagi 5. člena Severnoatlantske pogodbe. Med bistvene naloge SV spadata krepitev sodelovanja in zaupanja med SV ter vojskami zavezniških in prijateljskih držav ter uresničevanje interesov in nacionalnovarnostnih ciljev RS s sodelovanjem v MOM. Poleg naštetih nalog imajo bistven pomen tudi naloge zagotavljanja dvonamenskih zmogljivosti, sodelovanja pri zaščiti, reševanju in pomoči ob naravnih in drugih nesrečah ter podpora drugim državnim organom in organizacijam skladno z načrti, usposobljenostjo in opremljenostjo (Resolucija o splošnem dolgoročnem programu razvoja in opremljanja SV do leta 2025, 2010).

\footnotetext{
Angl. PMESII: Political, Military, Economic, Social, Infrastructure and Information.
} 


\subsection{Vloga Slovenske vojske v zavezništvu}

Slovenska vojska se je z vstopom Slovenije v Nato in Evropsko unijo (EU) zavezala $\mathrm{k}$ izpolnjevanju novih vlog in nalog predvsem pri zagotavljanju in ohranjanju mednarodnega miru, varnosti in stabilnosti. Kot pravi Vojaška doktrina (Furlan, 2006, str. 13), je Slovenija kot država članica prevzela odgovornost za skupno varnost. To med drugim zahteva skupno obrambno načrtovanje, sodelovanje pri oblikovanju skupnih odzivnih sil in njeno delovanje na kriznih območjih ter druge oblike vključevanja RS v dejavnosti zavezništva za zaščito stabilnosti severnoatlantskega območja in spoprijemanje z mednarodnim terorizmom ter drugimi nesimetričnimi grožnjami. Zavezništvo temelji na načelu, da je varnost vsake članice odvisna od varnosti vseh. To pomeni, da ogroženost ene članice vpliva na vse druge.

\subsection{Sodelovanje Slovenske vojske v mednarodnih operacijah in na misijah}

Slovenska vojska se spopada $\mathrm{z}$ izzivi in zahtevami za delovanje v MOM, med katerimi prevladujejo operacije v podporo miru. Kot navaja Likar (2009), je bilo prvo sodelovanje SV v operacijah kriznega odzivanja 14. maja 1997. V Albanijo je šlo na takratna krizna območja nekaj pripadnikov SV, med katerimi so bili tudi pripadniki zdravstvene enote (Role 1), ki so skrbeli za zdravstveno oskrbo sil ter evakuacijo poškodovancev.

Velikost slovenskih kontingentov (SVNKON) je zelo različna in se spreminja ter oblikuje glede na naloge in raven delovanja. Tako sta lahko za opravljanje nalog na strateški ravni ali za opravljanje nalog vojaškega opazovalca napotena le dva pripadnika, medtem ko lahko kontingent dosega večje število pripadnikov, tudi do 600 (Furlan v Grozde 2011, str. 34).

Predlog Obrambne strategije RS (2011, str. 2) opredeljuje sodelovanje SV predvsem v MOM znotraj Nata in EU, ki bolj neposredno vplivajo na nacionalno varnost. Tako so območja delovanja SV predvsem Jugovzhodna Evropa, Bližnji vzhod, Srednja Azija in Severna Afrika. Težišče sodelovanja je na območju Jugovzhodne Evrope, kjer ima RS zaradi geografske bližine ter zgodovinske povezanosti poleg varnostnih tudi politične, gospodarske, razvojne in druge interese ter možnosti za uporabo svojih primerjalnih prednosti v okvirih Nata in EU.

Pripadniki SV, ki so bili napoteni v MOM, so okolje, v katerem so delovali, poznali zelo različno - od poznanega do popolnoma nepoznanega. Pri tem opredeljujemo »okolje« kot širši pojem, pri čemer nas ne zanimajo samo geografske značilnosti neke države ali območja delovanja, temveč nas zanimajo tudi področja demografije ter zdravstvenih in socialnih razmer.

Za načrtovanje in vodenje operacij na transnacionalnih območjih delovanja so poleg geoprostorskih informacij pomembne informacije o zdravstvenih grožnjah, kot jih navaja Jurca (2006), med katere spadajo nalezljive bolezni, kontaminacija okolja, endemije, strupene rastline in živali ter težje mikroklimatske razmere. Avtorica 
sklepa na podlagi osebnih izkušanj, ki jih je pridobila v MOM, in glede na naravo dela, ki ga opravlja v odseku za laboratorijsko dejavnost v Vojaški zdravstveni enoti (VZE), da nepoznavanje in podcenjevanje zdravstvene ogroženosti lahko vodita $\mathrm{V}$ neustrezno preventivno zdravstveno načrtovanje ter nezadostno zdravstveno pripravo pripadnikov, kar se posledično lahko kaže z neuspešnostjo operacij na območju delovanja.

\section{PREOBLIKOVANJE OBVEŠČEVALNE DEJAVNOSTI}

Nove globalne grožnje in narava konfliktov, nova krizna žarišča in napredne tehnologije vodijo v nujnost sprememb v varnostnih sistemih in oboroženih silah. Odgovor na sodobne izzive je preoblikovanje vojaške organizacije iz funkcijske strukture v procesno, kar velja tudi za obveščevalno-varnostno dejavnost.

Obveščevalno-varnostna dejavnost se iz klasične ozke štabne organizirane dejavnosti s konceptom razvoja znanja reorganizira v centre znanja, v katerih se védenje in znanje zbirata, ob uporabi človeškega znanja in računalniških programskih orodij sistemsko analizirata ter posredujeta odločevalcem (Henigman in Rode, 2012, str. 84).

\subsection{Produktno osredotočen model obveščevalnega procesa}

Za funkcijsko ali klasično organizacijsko strukturo je značilno, da so pomembnejše navpične (vertikalne) povezave med posameznimi oddelki, med katerimi poteka zelo slaba komunikacija. Slaba stran funkcijske organizacije je, da poteka prek linije vodenja in poveljevanja, pri čemer mine veliko časa za zaprosilo, preverjanje, nadziranje in usklajevanje zahtevka za obveščevalno informacijo. Podatki in informacije so v zaprti arhitekturi ${ }^{2}$ v lasti obveščevalnih organov. Na voljo so samo izbranim naročnikom oziroma uporabnikom.

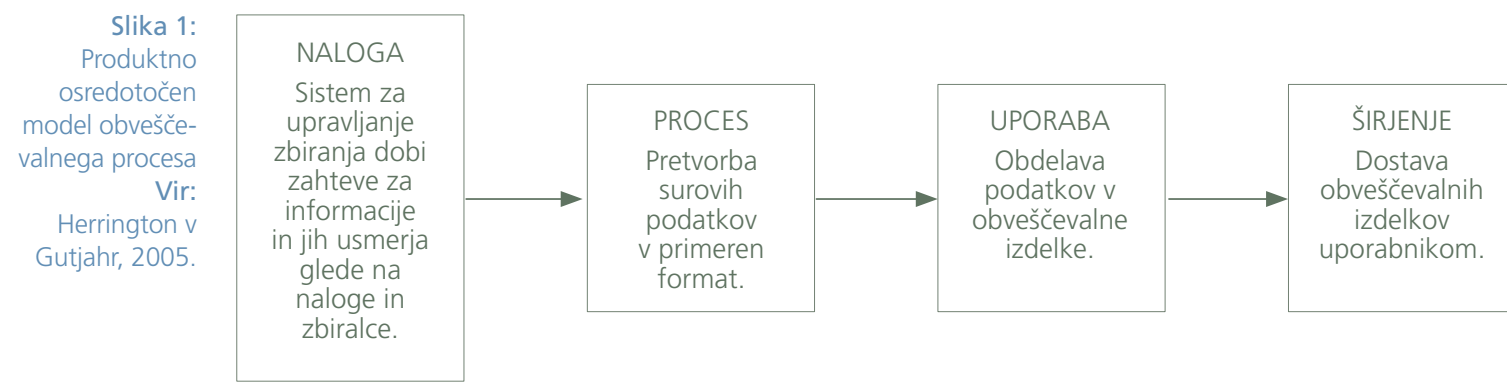

2 Produktno osredotočen model. 
»V funkcionalni oziroma klasični organizaciji so razmejene naloge in odgovornosti glede na organizacijski nivo, pri procesni organizaciji pa so naloge in odgovornosti vezane na celoten obveščevalni proces, ne glede na raven organiziranosti« (Šeme, 2012, str. 16).

\subsection{Uporabniško osredotočen model obveščevalnega procesa}

Procesna (horizontalna) organiziranost obveščevalno-varnostnega sistema vodi $\mathrm{k}$ racionalnejši, preglednejši in učinkovitejši obveščevalni zagotovitvi. Gre za celovito združevanje podatkov in informacij, ki bodo poveljnikom v procesu odločanja oziroma sprejemanja odločitev pravočasno in celovito (holistično) dostavljeni. Za doseganje koncepta procesne organiziranosti je nujna transformacija tradicionalnega produktno osredotočenega modela obveščevalnega procesa v uporabniško osredotočen model, ki predstavlja model prihodnosti.

Slika 2:

Uporabniško osredotočen model obveščevalnega procesa Vir: Herrington v Gutjahr, 2005.

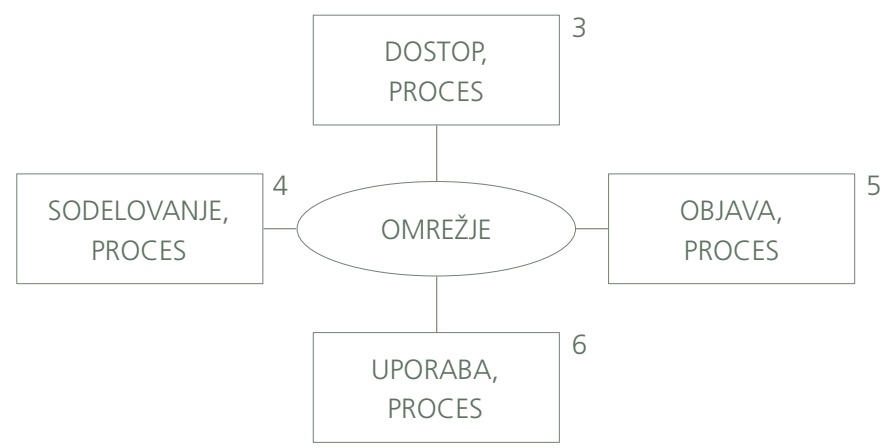

Kot navaja Šeme (2012, str. 18), je koncept »obveščevalne zbirke« eden izmed mogočih konceptov, iz katerega bi lahko dobili vzorec za organizacijo obveščevalne dejavnosti v SV. »Koncept uvaja pojem obveščevalne zbirke, ki odpira nove poglede na filozofijo obveščevalne dejavnosti predvsem na področjih shranjevanja, pregledovanja, načrtovanja in pridobivanja podatkov, funkcijskega, medresorskega in večnivojskega povezovanja s ciljem zagotoviti pravočasne in relevantne obveščevalne produkte, ki se navezujejo na vsebine in so v danem trenutku pomembni za naročnike obveščevalnih informacij.«

\footnotetext{
3 Sprotno zbiranje vseh relevantnih podatkov.

4 Zbiralci, obdelovalci in uporabniki pri zbiranju in obdelavi podatkov združujejo znanje.

5 Pooblaščenim uporabnikom omogočiti čim hitrejši dostop do podatkov.

- Obveščevalni podatki in informacije, katerih namen je dodana vrednost pri odločanju.
} 


\subsection{Obveščevalna dejavnost na področju zdravstva - MEDINT}

Obveščevalna dejavnost na področju zdravstva - MEDINT je bila v preteklosti nekoliko zapostavljena $\mathrm{v}$ primerjavi $\mathrm{z}$ razvojem in uporabnostjo obveščevalnih dejavnosti na drugih področjih. Za uveljavitev in izvajanje MEDINT je bilo treba zagotoviti tudi ustrezno kadrovsko podporo, predvsem strokovnjake s področja naravoslovnih ved.

Glavna naloga MEDINT je prepoznavanje groženj in pridobivanje podatkov s širšega geografskega območja o boleznih, ki ogrožajo zdravje ljudi in živali. Prepoznavanje okoljskih groženj je naloga strokovnjakov naravoslovnih ved, ki s svojim strokovnim znanjem posredujejo medicinske obveščevalne podatke glavni obveščevalni službi in tako pomagajo pri pripravi načrta za zdravstveno zaščito sile.

Zdravstvene podatke, ki so neomejeno dostopni po javnih virih, zbira osebje $\mathrm{z}$ ustrezno medicinsko izobrazbo. Pri tem bi se marsikdo vprašal, zakaj teh podatkov ne more zbirati osebje krovne obveščevalne dejavnosti. Razlog je $\mathrm{v}$ strokovnem znanju analitikov MEDINT, ki lahko pri ogledu zmogljivosti pridobijo izjemno pomembne podatke. V mednarodnih operacijah je med sodelujočimi nujna vsestranska in pospešena izmenjava teh podatkov. V sodobnem času, ko se vojaške operacije in misije izvajajo na ozemljih zunaj Natovega območja, je velika nevarnost zaradi izpostavljenosti zavezniških sil različnim dejavnikom tveganja za zdravje oziroma okoljskim grožnjam. Natov standard AJMedP-3 navaja (2008, str. 5-1), da ima okolje, poleg terorizma in orožja za množično uničevanje, pomembno vlogo pri združeni obveščevalni pripravi bojišča, saj so v njem različni škodljivi vplivi, ki zahtevajo posebno pozornost in so povezani z zemljepisnimi, vojaškimi, političnimi, kulturnimi in socialno-ekonomskimi vplivi.

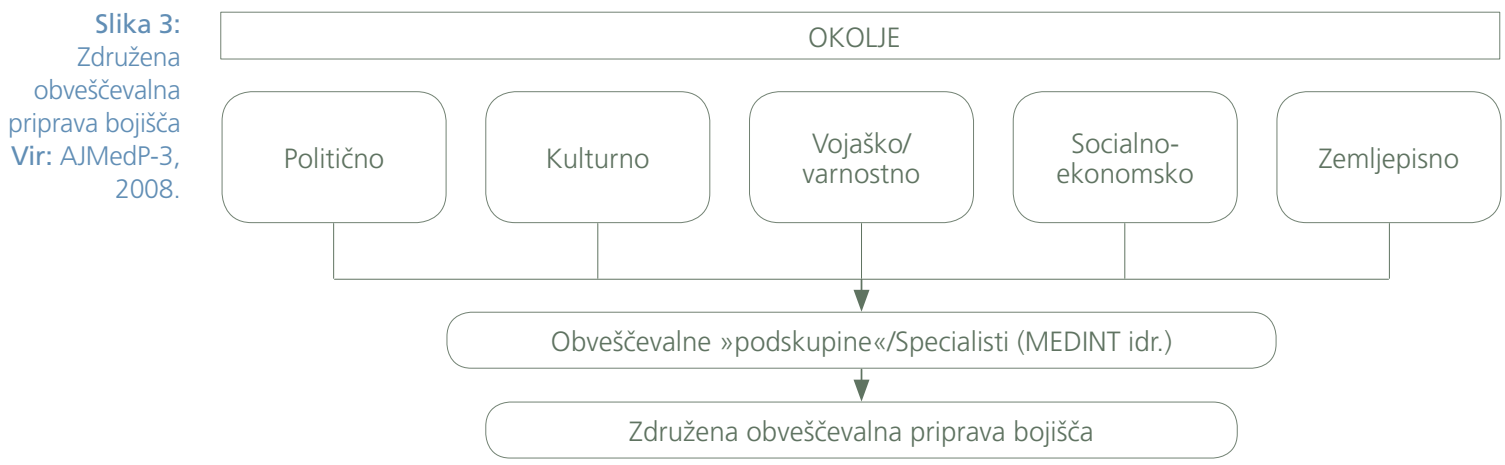


Strokovno zdravstveno osebje ima zelo pomembno vlogo, saj je odgovorno za zdravstveno pripravo sile, poleg tega pa mora zagotoviti obsežen program zdravstvene zaščite, ki temelji na pripravi načrta, ki podpira strateško, operativno in taktično raven operacije.

Za uspešen potek operacije je treba upoštevati dejavnike tveganja, ki škodljivo vplivajo na zdravstveno stanje sile. Ivanuša našteva nekaj kategorij (2012, str. 431) zahtevanih zdravstvenih podatkov, ki jih osebje MEDINT zbira in obdeluje ter posreduje uporabnikom.

Dejavniki okolja: Pripadniki, ki opravljajo naloge in operacije ekspedicijskega značaja, so na različnih geografskih območjih izpostavljeni številnim škodljivim vplivom, ki lahko bistveno vplivajo na njihovo sposobnost pri izvajanju nalog. Med dejavniki okolja, ki škodljivo vplivajo na zdravje ljudi, so kontaminacija tal, zraka, pitne vode in hrane ter prisotnost nekaterih strupenih rastlin in živali. Posebej je treba poudariti območja, na katerih je zaradi industrijskih emisij onesnaženost zraka zelo visoka. Med pomembne dejavnike okolja spadajo tudi težje mikroklimatske razmere.

Infekcijske bolezni: Najpogostejše nalezljive bolezni so tiste, ki jih povzročajo virusi in bakterije; glede na številčnost obolelih jih delimo na posamične, epidemije in pandemije. Kot ugotavlja Likar(2008, str.44), se v primerjavi s civilnim prebivalstvom za epidemijo šteje že 10 odstotkov obolelih vojakov v neki skupini. Posebnost so endemične bolezni, saj se pojavljajo na določenih območjih. Infekcijske bolezni s kratko inkubacijsko dobo omejujejo uspešnost operacije, medtem ko tiste z dolgo inkubacijo lahko povzročijo oslabitev premestljive sile in povzročijo obolevnost šele po vrnitvi v domače okolje.

Pri vojaško-civilnih zmogljivostih gre za zagotavljanje zdravstvenega varstva oboroženim silam in civilnemu prebivalstvu. Ivanuša poudarja (2012), da se ob naravnih nesrečah in v vojnih razmerah na podlagi organiziranosti, učinkovitosti in medsebojne podpore vojaško-civilnega zdravstvenega sistema določi učinkovitost zmogljivosti. Pri tem ne smemo spregledati še zmogljivosti in lokacij bolnišnic ter objektov primarnega zdravstva, saj se na podlagi teh podatkov odločimo, ali so zmogljivosti uporabne ali se jim je bolje izogniti.

»Jedrska, radiološka, kemična in biološka obramba - JRKBO in nova orožja: Podatki o narodni sposobnosti obrambe pred JRKB-agensi in novimi orožji ter njihov strateški in operativni vpliv na narodno ravnovesje so nesporno nujni« (Ivanuša, 2012, str. 432).

Zdravje črede oziroma jate in zmogljivosti veterinarske medicine: Gre za pridobivanje zdravstvenih podatkov širšega pomena, saj so uporabni pri načrtovanju in pri pripravi končnih mnenj. 
Naravoslovno znanje in biotehnologija: Z razvojem nove tehnologije, novega znanja in biotehnoloških postopkov so se uveljavile nove oblike zdravljenja, preizkušajo se nova cepiva in zdravila. Pri tem je treba upoštevati možnost tveganja dvojne uporabe, zato je treba dobiti podatke o novih tehnologijah, znanju in razvoju.

\section{VREDNOTENJE CELOVITE PRIPRAVE PRIPADNIKOV ZA MEDNARODNE OPERACIJE IN MISIJE}

Resolucija o splošnem dolgoročnem programu razvoja in opremljanja Slovenske vojske do leta 2025 (2010, str. 11) navaja, da se je v sodobnem mednarodnem varnostnem okolju verjetnost oboroženega meddržavnega izbruha zelo zmanjšala. $\mathrm{V}$ prihodnje bodo na mednarodno varnost vplivali predvsem neugodne naravne spremembe (podnebje), globalna finančna, demografska, socialna in gospodarska gibanja, omejenost naravnih in drugih strateških virov ter nenadzorovano trgovanje in storitve. Sodobne grožnje varnosti bodo hibridne grožnje, ki poleg konvencionalnih oblik vključujejo tudi terorizem, kriminal in neustaljene oblike delovanja, zlorabe informacijske tehnologije ter različnih gospodarskih in drugih dejavnosti.

Tudi v prihodnje bo SV sodelovala v večnacionalnem vojaškem okviru, v katerem bo delovala tako v konvencionalnih oblikah kot tudi proti hibridnim grožnjam. Kot pravi Grozde (2011, str. 71), bodo pri odzivanju SV na krizna žarišča imele prednost MOM na območjih Jugovzhodne Evrope, Bližnjega vzhoda, Srednje Azije in Afrike. Pripadnikom SV, ki opravljajo in bodo opravljali svoje poslanstvo na različnih geografskih območjih, je njihovo poznavanje PMESII z vidika geografskih in družbenih sistemov, z izjemo Zahodnega Balkana, slabo. Celovit pristop, ki temelji na poznavanju in razumevanju geografskega prostora in družbe kriznega območja, je zelo pomemben za ugotavljanje dejavnikov, ki vplivajo na uresničitev nalog, na prepoznavanje prednosti in slabosti ter tveganja lastnih sil kot tudi sil nasprotnika in drugih udeležencev. Pri napotitvi pripadnikov SV v MOM ima poleg celovite priprave operativnega okolja zelo pomembno vlogo ocena zdravstvenih in okoljskih virov ogrožanja.

Na podlagi intervjujev pripadnikov Vojaške zdravstvene enote, ki opravljajo svoje naloge v oddelku za preventivo, pripadnikov vojaške obveščevalne dejavnosti, pripadnika OVS (Obveščevalno varnostna služba) in poveljnikov kontingentov lahko predstavimo nekatere ugotovitve oziroma dejstva. OVS kot tudi drugi obveščevalno-varnostni organi v SV nimajo razvitih funkcionalnih obveščevalnih disciplin7, kar pomeni, da se v analize lahko vključijo strokovnjaki iz civilnega okolja ali posamezniki specialisti oziroma se informacije pridobijo prek javnih

\footnotetext{
Različna uporaba terminov za načine pridobivanja obveščevalnih podatkov.1. Pridobivanje obveščevalnih podatkov se izvaja z obveščevalnimi disciplinami (http://www.fvv.uni-mb.si/dv2008/zbornik/clanki/GrozdeHenigman.pdf). 2. D. Črnčec V knjigi Obveščevalna dejavnost v informacijski dobi (2009) uporablja termin zvrsti za načine pridobivanja podatkov na obveščevalnem področju. Terminologija ni enotna; kateri izraz oziroma termin je ustreznejši/pravilnejši odpira novo poglavje razprave.
} 
virov $^{8}$. Na podlagi sklenjenih dvostranskih državnih sporazumov se informacije lahko pridobivajo tudi pri partnerskih službah in vojskah.

Po pridobljenih podatkih so pripadniki med pripravami za odhod v MOM precej slabo seznanjeni s podatki, ki se nanašajo na dejavnike tveganja oziroma na oceno tveganja za zdravje. Vedeti moramo, da je geografska razpršenost mednarodnih operacij in misij, v katerih trenutno sodeluje tudi SV, velika, predvsem pa je treba pri dejavnikih tveganja za zdravje razlikovati med operacijo, ki poteka na Balkanu, in tisto v tropski Afriki. Po pripovedovanju pripadnikov imajo ti o cepljenju in antimalarikih zelo različna mnenja. To kaže na dejstvo, da v programu priprav pripadnikov na MOM manjka zelo pomembno področje, ki ga imenujemo medicinska geografija.

V prihodnje se bo SV soočila z izzivi in zahtevami za delovanje v mednarodnih operacijah in na misijah predvsem na ozemljih, na katerih bo izpostavljena različnim boleznim oziroma zdravstvenim grožnjam, ki jih v domačem okolju ni. Te vrste groženj povečujejo zaskrbljenost in zahtevajo učinkovito preventivno delovanje. Za tako zagotovitev je najpomembnejša vzpostavitev medicinske obveščevalne dejavnosti, ki zaradi svojega poslanstva zahteva poleg obveščevalnega osebja tudi osebje z različnim drugim znanjem in obvladovanjem naravoslovnega znanja.

Da bi se izognili nadaljnjemu neučinkovitemu sistemu delovanja, katerega naloga je oceniti geografska in zdravstvena tveganja, ki bi jim bile zavezniške sile lahko izpostavljene, analizirati zdravstvene zmogljivosti in sposobnosti na območju delovanja ter izdelati analize groženj, predstavljamo predlog modela MEDINT v SV. Predlog temelji na modelu, ki ga je predlagal in opisal Grozde (2011) na procesu geoprostorske obveščevalne podpore SV za MOM.

Celovita priprava operativnega okolja v našem modelu vključuje tudi vrednotenje obveščevalnih podatkov s področja zdravstva, ki neizhajajo le iz ciljnega geografskega prostora, temveč tudi iz transnacionalnega prostora. $\mathrm{V}$ tabeli 1 je prikazan predlagan izpopolnjen in nekoliko prirejen proces obveščevalnega vrednotenja geografskega prostora, saj smo v posamezne stopnje dodali sodelovanje medicinske geografske obveščevalne podpore. Proces je razdeljen na štiri dele, ki se naprej delijo na različno število časovnih stopenj. Model predstavlja vključevanje posameznih služb znotraj MO RS (Ministrstvo za obrambo RS) na vseh štirih stopnjah napotitve v MOM.

$\mathrm{Na}$ vseh štirih stopnjah napotitve se začnejo izvajati in dodeljevati naloge na posameznih ravneh. Bistvena sta prepoznavanje in ocena okoljskih in zdravstvenih virov ogrožanja, ki bi jim lahko bile izpostavljene sile SV.

$\&$ Open Source Intelligence (OSINT). 
Tabela 1: Proces medicinskogeografskega vrednotenja prostora napotitve po stopnjah Vir: Grozde, 2011.

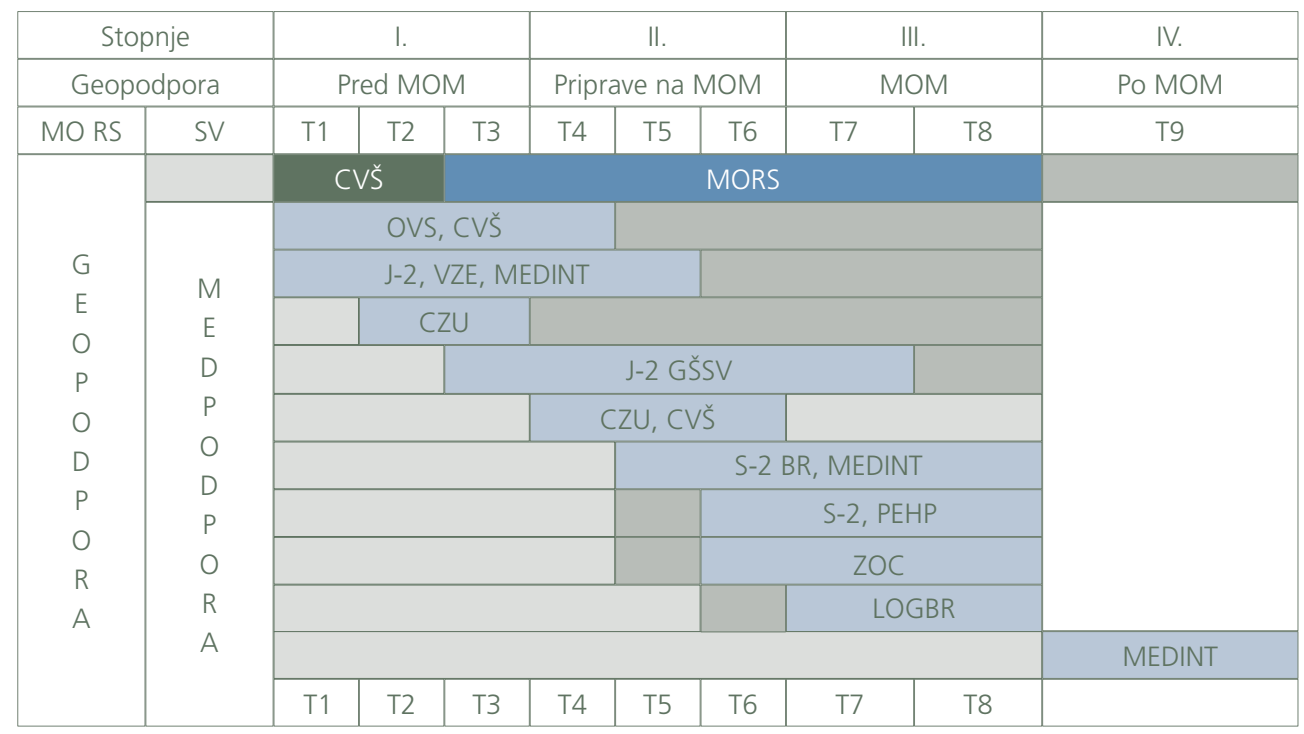

Legenda:

\begin{tabular}{|l|l|}
\hline Sodeluje \\
\hline Sodeluje po potrebi \\
Geoprostorski podatki in informacije \\
Javni viri \\
Ne sodeluje
\end{tabular}

\section{I. stopnja: Pred angažiranjem SV v MOM}

\section{T1: Dokumentarna obveščevalna dejavnost}

Opravi se celovita analiza okolja kriznega žarišča, v katero so vključeni zgodovinska dogajanja, geografske značilnosti geoprostora ter zdravstvena problematika. V tem procesu sodelujejo GŠSV ${ }^{9}, \mathrm{CVS}^{10}$ in OVS, ki izdelajo celovito pripravo operativnega okolja. Na prvi stopnji manjka najpomembnejši del, to je MEDINT, ki naj bi v okviru S-2 VZE ali J-2 ${ }^{11}$ GŠSV opravil poizvedovanje o zdravstvenih in okoljskih virih ogrožanja.

\footnotetext{
9 Generalštab Slovenske vojske.

${ }^{10}$ Center vojaških šol.

"Sektor za obveščevalne zadeve.
} 


\section{T2: Situacijska obveščevalna dejavnost}

Situacijska obveščevalna dejavnost se začne takrat, ko neko območje postane interesno območje zavezništva. V tem procesu sodelujejo OVS, J-2, MO, GEOpodpora, CZU ${ }^{12}$ in MEDINT S-2 VZE/J-2 GŠSV.

T3: V tretji točki prve stopnje se opravi analiza stanja in se zberejo obveščevalni produkti območja. Ob prvi napotitvi na povsem novo območje delovanja SV naj se osebje MEDINT posvetuje s strokovnjaki različnih naravoslovnih področij. Na podlagi pridobljenih podatkov in $\mathrm{v}$ sodelovanju $\mathrm{z}$ nacionalnimi naravoslovnimi ustanovami ter članicami zavezništva naj bi strokovno osebje MEDINT pripravilo analizo začetne presoje groženj in zdravstvenih zmogljivosti ter sposobnosti na območju delovanja. Pripraviti je treba načrt in obseg cepljenja kot preventivnega ukrepa za preprečevanje in obvladovanje nalezljivih bolezni.

\section{II. stopnja: Priprave na MOM}

T4: CZU/CVŠ začne priprave s postavitvijo simulacijskega modela, pri tem aktivno sodelujeta OVS in J-2.

T5: Vključitev enote oziroma izbranega bataljona, katerega sile bodo opravljale naloge v MOM. Proces obsega ogled interesnega območja. OVS preda analize J-2, GEO-podpora MO pa preda bazo UDIGISP ${ }^{13}$ in GEO-portalu. Ciljno zdravstveno osebje MEDINT naj bo vključeno v kratke analize misije in začetne presoje groženj. Po ogledu interesnega območja in pridobljenih podatkih o zdravstvenih in okoljskih grožnjah bi bilo treba oceniti tveganje ter pripraviti epidemiološko poročilo.

T6: Zadnja točka druge stopnje je namenjena usposabljanju, pripravam in preverjanju pripravljenosti pripadnikov v MOM. Pri tem sodeluje GŠSV, in sicer J-2, CVŠ in CZU. V zdravstvenem centru VZE se izvajajo preventivni zdravniški pregledi, ki obsegajo razširjen obseg preiskav. Glede na izvide preiskav se ugotovi zdravstvena sposobnost oziroma nesposobnost pripadnikov za opravljanje nalog na območjih zunaj tradicionalnih meja. Tudi $\mathrm{v}$ tem procesu bi moralo sodelovati strokovno osebje MEDINT, ki bi s svojim strokovnim predavanjem ozaveščalo pripadnike o zdravstvenih grožnjah in ukrepih za zaščito lastnih sil.

\section{III. stopnja: MOM}

T7: Oborožene sile SV opravljajo naloge skladno z navodili nadrejenega poveljstva. J-2 in S-2 brigade aktivno sodelujeta s silami v MOM, prav tako logistična brigada zagotavlja logistično podporo. OVS in J-2 sodelujeta, če je treba, medtem ko CVŠ na tej stopnji nima naloge. Če se zgodijo spremembe na območjih delovanja, morajo enote posredovati informacijo v matično okolje.

\footnotetext{
12 Center za združeno usposabljanje.

${ }^{13}$ Upravljanje in distribucija GIS-podatkov.
} 
T8: S-2 brigade in bataljona aktivno sodelujejo pri podpori vojaške aktivnosti. J-2 in OVS sodelujeta, če je treba. Pri obeh točkah tretje stopnje naj bi sodeloval tudi MEDINT. Gre za spremljanje zdravstvene situacije sile na območju delovanja, spremljanje izbruhov oziroma okoljskih in zdravstvenih groženj ter posredovanje informacij poveljniku kontingenta.

\section{IV. stopnja: Po vrnitvi iz MOM}

T9: Na tej stopnji sodelujoči pripadniki obveščevalne dejavnosti naredijo analizo opravljene naloge. CVŠ predlaga načelniku GŠSV uvajanje primerov dobre prakse in odpravo zaznanih pomanjkljivosti. Ugotovljene spremembe na področju geoprostora in geoinformacij $\mathrm{v}$ operativnem okolju $\mathrm{J}-2 \mathrm{v}$ sodelovanju $\mathrm{z}$ OVS predajo GEO-podpori MO, ki jo vnese $\mathrm{v}$ UDiGISP in centralno geoprostorsko bazo geoportala MO. Dostop do baze je urejen z akti vodenja in poveljevanja. Vsi pripadniki se po vrnitvi iz MOM udeležijo zdravniškega pregleda z razširjenim obsegom laboratorijskih preiskav. Slika 4 prikazuje vključevanje obveščevalnega ciklusa MEDINT v obveščevalni ciklus krovne obveščevalne dejavnosti ter stalno povezavo med MEDINT in zdravstvenim sistemom. MEDINT na prvi in drugi časovni stopnji zagotavlja najpomembnejše podatke za zdravstveno zaščito sile. Končni obveščevalni proizvod, ki vključuje oceno zdravstvene ogroženosti, je glavni proizvod MEDINT, in sicer kot odgovor na poveljnikove zahteve.

\subsection{Organizacija in delovanje vojaškega zdravstva na primeru majhnih držav}

\subsubsection{Republika Hrvaška}

Vojaško zdravstvo Republike Hrvaške je v organizacijski strukturi del logističnomedicinskega podpornega sistema. Kot je navedeno v Almanac of Medical Corps Wordwide (2013), ima Hrvaška tako imenovani integriran nacionalni sistem zdravstvenega varstva $\mathrm{z}$ izjemo Role 1, katerega zmogljivosti pokriva vojaška zdravstvena služba. Kadar je zahtevana višja raven upravljanja zdravstvenih zmogljivosti, to vlogo prevzamejo civilne zdravstvene strukture. Celovita zdravstvena podpora v oboroženih silah Hrvaške je organizirana in usklajena kot poseben funkcionalni sistem, ki temelji na doktrinarnih dokumentih Nata, ki so skladni z zahtevanimi nacionalnimi predpisi. Hrvaška nima vojaške bolnišnice, zato je Vojaški zdravstveni center glavni vojaški objekt v Oboroženih silah Hrvaške, ki je odgovoren za primarno in preventivno zdravstveno varstvo ter veterinarsko medicino. V organizacijsko strukturo spadajo Oddelek za primarno zdravstveno varstvo, Oddelek za veterino, Oddelek preventivne medicine, Poveljstvo Role 2 ter dva inštituta, in sicer Inštitut zračne medicine in Inštitut pomorske medicine.

\subsubsection{Slovaška republika}

Naloga, ki jo opravlja zdravstvena služba Slovaške, je zagotavljanje temeljne zdravstvene oskrbe in specialistične diagnostike, namenjene pripadnikom Slovaške vojske, nekdanjim vojakom in njihovim sorodnikom. V Almanac of Medical Corps Wordwide (2013) Slovaška predstavlja organizacijsko strukturo, v kateri je poveljnik 
oziroma strokovni vodja osrednji organ vojaške zdravstvene dejavnosti (enote) oboroženih sil Slovaške. Bolnišnica v Ružomberoku je največja vojaška bolnišnica na ozemlju Slovaške. Ustanovljena je bila leta 1994 kot vojaška bolnišnica Ružomberok in se je še istega leta preimenovala v Centralno vojaško bolnišnico Ružomberok.

\subsubsection{Irska}

Glavno poslanstvo vojaškega zdravstva (Medical Corps) v oboroženih silah Irske je zagotavljanje zdravstvene podpore, preprečevanje bolezni med pripadniki in dobra zdravstvena pripravljenost pripadnikov, nujna za opravljanje aktivnosti doma in v tujini. Vojaška bolnišnica St. Bricins Military Hospital je v Dublinu in zagotavlja tako bolnišnično kot ambulantno oskrbo. Poleg tega se v njej izvajata radiološka in laboratorijska diagnostika. V okviru vojaškega zdravstva potekajo usposabljanja s področja zdravstvene tematike, ki se jih udeležujejo zdravstveno osebje in drugi pripadniki. Pripadniki vojaškega zdravstva se udeležujejo vseh večjih mednarodnih operacij in misij, na katerih opravljajo pomembne naloge pri zdravstveni in zobozdravstveni podpori. V civilno-vojaškem sodelovanju vojaško zdravstvo izpolnjuje pomembno vlogo pri izvajanju humanitarne pomoči civilnemu prebivalstvu (Almanac, 2013).

»Po pridobitvi podatkov, tudi zelo skopih, glede organizacije in delovanja vojaškega zdravstvenega sistema na primeru nekaterih majhnih evropskih držav, lahko rečemo, da je osnovno poslanstvo primerljivo s poslanstvom Vojaške zdravstvene službe SV. Do razlikovanj prihaja v zdravstvenih zmogljivostih in vojaških zdravstvenih objektih; npr. vojaške bolnišnice, ki jih nekatere zgoraj primerljive države imajo, druge pa jih nimajo. Podatkov glede upravljanja MEDINT zgoraj omenjenih držav nismo uspeli pridobiti, razen za Republiko Hrvaško, ki omenja, da za celovito zdravstveno podporo oboroženih sil Hrvaške poleg nacionalnih predpisov uporablja tudi Natovo doktrino« (Kremžar, 2014, str. 44).

\subsection{Obveščevalni ciklus MEDINT}

Slika 4 prikazuje vlogo MEDINT v razmerju med zdravstvenim sistemom in krovno obveščevalno dejavnostjo. Zbiranje zdravstvenih podatkov mora postati naloga izključno odgovornega in predanega zdravstvenega osebja MEDINT, saj na primer pri ogledu interesnega območja njegovi analitiki pridobijo veliko pomembnih podatkov, ki bi si jih osebje brez strokovnega znanja razložilo povsem drugače. Kot poudarja Ivanuša (2012), se podatki o oceni okoljskih in zdravstvenih virov ogrožanja, o analizi zdravstvenih zmogljivosti in sposobnostih na območju delovanja morajo vključiti v obrazec, ki ga predpisuje STANAG $2481^{14}$. Na podlagi povzetka MEDINT je treba pripraviti osnutek in operacijski načrt zdravstvene podpore sile. Poleg tega je treba skladno z usmeritvami pripraviti strokovno epidemiološko poročilo.

Pomanjkanje strokovnega zdravstvenega osebja v obveščevalnih službah se kaže tudi v tem, da ima osebje obveščevalne dejavnosti težave oziroma premalo znanja o

${ }^{14}$ Medical Information Collection and Reporting. 
Slika 4: Vloga MEDINT v razmerju med zdravstvenim sistemom in krovno obveščevalno dejavnostjo Vir: Ivanuša, 2012.

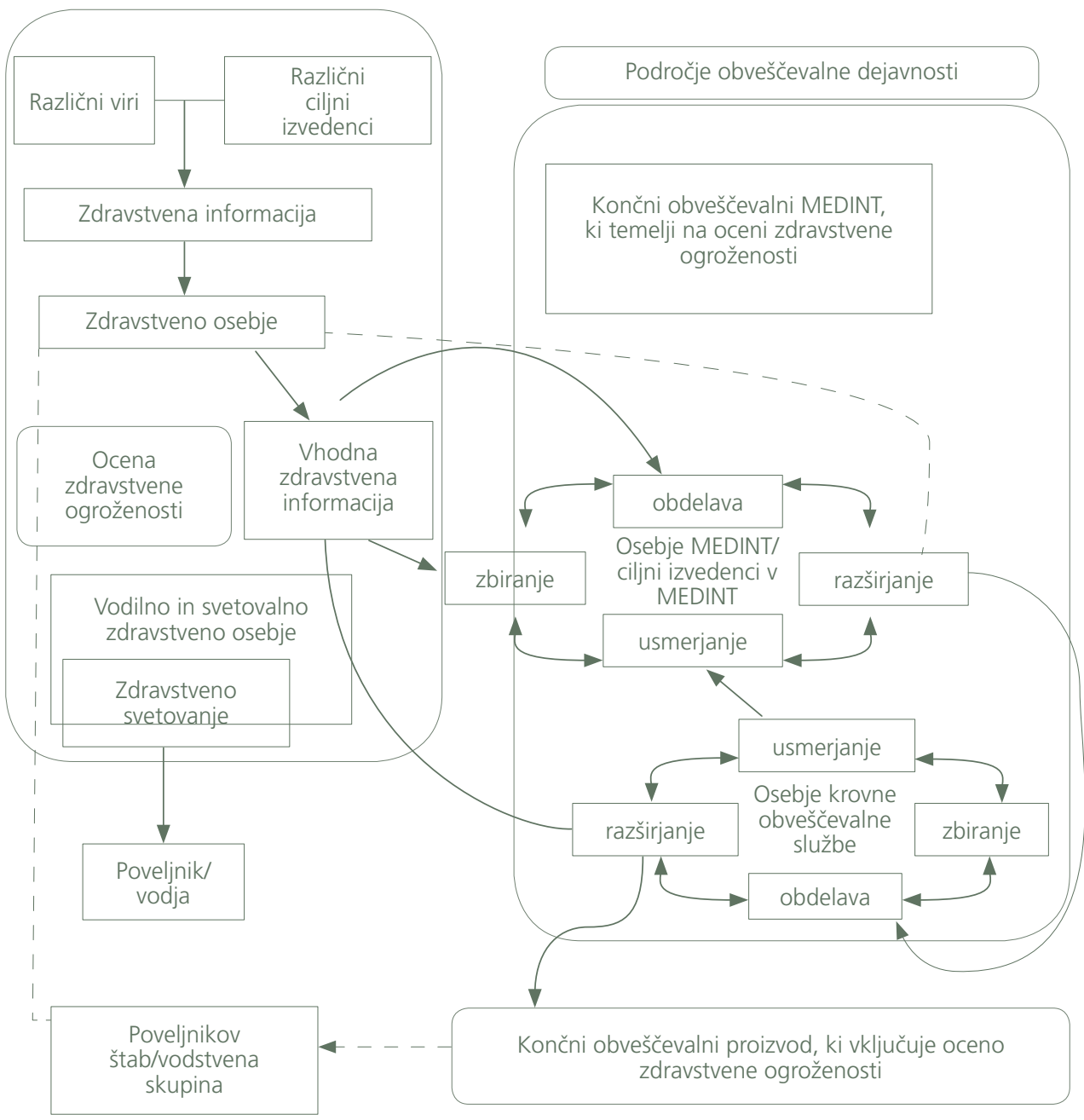

zahtevanju zdravstvenih podatkov. Da je sodelovanje med obveščevalno dejavnostjo, strokovnim zdravstvenim osebjem MEDINT in zunanjim zdravstvenim sistemom nujno, je razvidno že iz prve stopnje obveščevalnega ciklusa MEDINT. Usmerjanje kot njegova prva stopnja je namenjeno načrtovanju in zbiranju zdravstvenih podatkov. Usmerjanje lahko odredi poveljnik ali pa ga osebju krovne obveščevalne dejavnosti predlagajo strokovno osebje MEDINT in strokovnjaki zdravstvenih služb. Druga stopnja obveščevalnega ciklusa je zbiranje zdravstvenih podatkov z uporabo ciljnih strokovnih virov. Kot navaja Ivanuša (2012), moramo biti na tej stopnji posebno pozorni na pravočasno posredovanje zbranih zdravstvenih podatkov na stopnjo obdelave, saj se lahko zgodi, da ti podatki med zbiranjem na območju MEDINT hitro zastarajo, predvsem ko gre za podatke o bioloških agensih. Na stopnji obdelave 
se obveščevalni podatki pridobivajo s primerjanjem, vrednotenjem, analiziranjem in združevanjem podatkov. Gre za presojo zanesljivosti vira in resničnosti podatka. $\mathrm{Na}$ tej stopnji se zdravstveni podatki, zbrani kot odziv usmeritve poveljnika, spremenijo v medicinske obveščevalne podatke. Zadnja stopnja ciklusa MEDINT je razširjanje, ki temelji na pravočasnosti prenosa proizvodov MEDINT obveščevalnemu osebju, ki prevzame odgovornost nadaljnjega razširjanja obveščevalnih informacij.

Menimo, da bi strokovno osebje MEDINT moralo za vsako geografsko območje, na katerem pripadniki SV opravljajo naloge v podporo miru, pripraviti bazo oziroma knjižnico podatkov o boleznih in drugih okoljskih dejavnikih tveganja, ki vplivajo na zdravje ljudi in živali. Ti podatki bi bili seveda klasificirani, saj bi med obdelavo v obveščevalnem ciklu pridobili vrednost medicinsko-obveščevalnega podatka. Tako bi baza podatkov vsebovala seznam bolezni in bi bila na voljo za ogled tako osebju MEDINT kot osebju obveščevalne dejavnosti.

Sklep Slovenska vojska se poleg nalog nacionalne obrambe spopada z izzivi in zahtevami za delovanje $\mathrm{v}$ mednarodnih operacijah in na misijah v okoljih velike geografske razpršenosti in v težkih podnebnih razmerah. Republika Slovenja se s članstvom v EU in Natu zavzema za zagotavljanje in ohranjanje mednarodnega miru, varnosti in stabilnosti. V mednarodnem varnostnem okolju, v katerem delujejo oborožene sile zavezništva, so poleg novih oblik ogrožanja varnosti, tako imenovanih hibridnih groženj, kot vir ogrožanja vedno bolj izraženi podnebne spremembe, naravne in druge nesreče ter različni učinki globalizacije. Zelo pomemben vir ogrožanja, predvsem v okoljih zunaj Natovega območja, ki so jim oziroma jim bodo sile zavezništva izpostavljene, so različne bolezni, ki jih v matičnem okolju ni.

Vojaška obveščevalna dejavnost SV v sodelovanju z OVS omogoča celovito obveščevalno-varnostno podporo pripadnikom SV V MOM. Pravočasno zagotavljanje obveščevalno-varnostnih podatkov omogoča poveljniku podporo pri sprejemanju odločitev in pripravi načrta za zaščito lastnih sil. Geografska razpršenost mednarodnih operacij in misij, predvsem na ozemljih Srednje in Severne Afrike, zahteva zagotavljanje učinkovite obveščevalno-varnostne podpore pripadnikom $\mathrm{SV}$, ki pa je obrambni sistem v celoti ne more zagotoviti, zato se povezuje s tujimi obveščevalnimi službami. Tako se pridobijo podatki, ki obsegajo tudi analizo nasprotnikovih družbenih sistemov PMESII in se uporabijo v pripravah pripadnikov SV v MOM.

SV in sile zavezništva delujejo na območjih, ki so zaradi posledic vojnih razmer doživela izrazito poslabšanje tako na področjih socialne in zdravstvene varnosti kot na področjih gospodarskih, ekonomskih in političnih sistemov. Poškodovana ali uničena infrastruktura in slabe higienske razmere so pogosto vzrok onesnaženosti tal, pitne vode ter izbruhov alimentarnih toksikoinfekcij.

Izpostavljenost različnim zdravstvenim in okoljskim grožnjam se povečuje z večjo geografsko oddaljenostjo od matičnega okolja. Z izjemo Balkana, ki ga ne smemo 
zanemarjati, ko govorimo o dejavnikih tveganja za zdravje, saj se na tem ozemlju še vedno pojavljajo izbruhi nove gripe, so pričakovanja in zaskrbljenost pripadnikov zaradi zdravstvene zaščite večja ob njihovi napotitvi na območja Bližnjega vzhoda, Afrike in Azije.

V procesu medicinsko-geografskega vrednotenja prostora se pri obveščevalni pripravi bojišča oziroma prostora dajejo mnenja in delajo analize (zgodovinske, geografske, politične, vojaške, socialne, ekonomske, itd.) o kriznih žariščih, torej o območjih, ki zanimajo RS za sodelovanje. Pri celoviti obveščevalni pripravi bojišča oziroma prostora bi moral pomagati organ, ki v sestavi strokovnjakov različnih naravoslovnih ved daje mnenje o zdravstveni zaščiti sil (predlog modela). Za tako delovanje je treba uvesti program oziroma dejavnost, ki bo omogočala zagotavljanje zdravstvene zaščite sile pred in med operacijami ter po njih. Obveščevalna dejavnost na področju zdravstva se ukvarja z zbiranjem medicinskih, bioznanstvenih, epidemioloških, okoljskih in drugih podatkov, ki se kakor koli nanašajo na zdravje ljudi in živali.

Ravno zato MEDINT za uspešno delovanje potrebuje v svojem krogu strokovnjake različnih naravoslovnih smeri (zdravnik, biolog, veterinar idr.), ki bi bili dodatno usposobljeni za področja obveščevalnih dejavnosti in bi strokovno ter predano opravljali svoje delo.

Glede na trenutne razmere pri pripravah pripadnikov na MOM in po informacijah, ki smo jih dobili z intervjuji, lahko rečemo, da je zagotavljanje zdravstvene zaščite zavezniških sil učinkovito pri vzpostavitvi strokovne skupine za MEDINT in izvajanju njegovega programa $\mathrm{v}$ sodelovanju $\mathrm{z}$ osebjem obveščevalne dejavnosti znotraj MO ter z nacionalnimi zdravstvenimi ustanovami.

1. Bandekow, L., 2013. Almanac of Medical Corps Worldwide 44-45, Nemčija, str. 8990,140-143.

2. Črnčec, D., 2009. Obveščevalna dejavnost v informacijski dobi. Ljubljana: Defensor.

3. Furlan, B., Rečnik, D., Vrabič, R., Marǎ̌, V., Cerkovnik, J., Špur, B., Šonc, M., Tušak, M., Ivanuša, M., Gorjup, B., Kojadin Lasič, U., Unger, M., 2006. Vojaška doktrina. Ljubljana: Defensor:

4. Grozde, J., 2012. V Geoprostorska podpora obrambnemu sistemu Republike Slovenije. Geoprostorska obveščevalna podpora Slovenski vojski v pripravah na mednarodne operacije in misije. Ministrstvo za obrambo RS. Geodetski inštitut Slovenije. ZRC SAZU. Ljubljana: MO RS, str. 135-150.

5. Grozde, J., 2011. Obveščevalno vrednotenje geografskega prostora območij delovanj Slovenske vojske (Zaključna naloga). Maribor: Poveljniško-štabna šola.

6. Gutjahr, M. H., 2005. The Intelligence Archipelago: The Community's Struggle to Reform in the Globalized Era. The Joint Military Intelligence College.

7. Henigman, Ž., in Rode, A., 2012. Smernice razvoja obveščevalno-varnostne dejavnosti 21. stoletja. Bilten Slovenske vojske. Znanstveno- strokovna publikacija SV, 14(1), str. 69-84.

8. Ivanuša, T., 2012. Obveščevalno-varnostna dejavnost: Procesi, metode, nadzor. VI. Podbregar (ur.), Obveščevalna dejavnost na področju zdravstva - MEDINT. Znanstvena monografija. Ljubljana: Fakulteta za varnostne vede. 
9. Jurca, I., 2006. Vključevanje civilnih zmogljivosti v operacije v podporo miru. $V$ Pipenbaher, B. (ur). Zdravstvene razmere na območju operacij v podporo miru in preventivni ukrepi Ljubljana: Ministrstvo za obrambo, Direktorat za obrambne zadeve, Sektor za civilno obrambo, str. 185-192.

10. Kremžar Kovač, T., 2014. Izvajanje vojaško medicinske obveščevalne dejavnosti z omejenimi viri na primeru majhnih držav. (Magistrsko delo). Ljubljana: Fakulteta za varnostne vede.

11. Likar, S., 2009. Obveščevalno-medicinski podatki v Slovenski vojski. (Diplomsko delo). Ljubljana: Fakulteta za varnostne vede.

12. Mikuž, I., 2012. Strategy Research Project International Fellow. Influence Small State Force Design. United States Army War College.

13. NATO Standardization Agency, 2008. Allied Joint Medical Doctrine for Medical Intelligence (MEDINT) - AJMedP-3. Brussels: NATO Standardization Agency.

14. Resolucija o splošnem dolgoročnem programu opremljanja in razvoja Slovenske vojske do leta 2025 (ReSDPRO), 2010. Uradni list RS, 99/10.

15. Sunzi (2009). Umetnost vojne. Mladinska knjiga Založba,d,d, Ljubljana.

16. Šeme, R., 2012. Učinkovita obveščevalna zagotovitev v Slovenski vojski (Zaključna naloga). Maribor: Poveljniško-štabna šola.

17. Zakon o obrambi, 2004. Uradni list RS, 103/04.

18. Zakon o službi v Slovenski vojski, 2007. Uradni list RS, 68/07. 


\section{PROBLEMI VOJAŠKO-VARNOSTNEGA POGODBENIŠTVA V IRAKU IN AFGANISTANU}

Tematika vojaške privatizacije, pri čemer mislimo tako na privatizacijo oskrbe vojske kot na privatizacijo vojaške dejavnosti v splošnem, je aktualna zlasti v obdobju vojne v Iraku, ki se je začela leta 2003, in po njem. Različna zasebna vojaška podjetja so seveda delovala že prej (na primer zdaj nedelujoči podjetji Executive Outcomes in Sandline International), prav tako vedno več vojaške oskrbe opravljajo zunanji pogodbeniki vse od uvajanja poklicnega popolnjevanja vojsk, vendar pa so se zasebna vojaško-varnostna podjetja zelo razširila med aktualnimi konflikti v Iraku in Afganistanu. Delo Thomasa R. Mockaitisa Soldiers of Misfortune? (Strategic Studies Institute and U. S. Army War College Press, May 2014. ISBN 1-58487-613-1) predstavlja delovanje zasebnih vojaških podjetij v omenjenih konfliktih, pri čemer prav posebej poudarja problematiko oboroženih pogodbenikov. Avtor ugotavlja, da oskrbno-logistična dejavnost (vodenje vojaških baz oziroma prevzem nastanitev, oskrbe s prehrano, pralnic ipd.) večinoma ni težavna, kadar jo izvajajo zasebni pogodbeniki, drugače pa je z vključitvijo oboroženih pripadnikov zasebnih vojaškovarnostnih podjetij $\mathrm{v}$ ameriško delovanje. Na podlagi uradnih poročil predstavi najbolj izpostavljene incidente in probleme (prehitro in nepotrebno odpiranje ognja pri zagotavljanju oboroženega spremstva, vključevanje lokalnih pogodbenikov, plačevanje vaškim vodjem za neoviran prehod, kultura nekaznovanja ipd.) ter tako brutalno razkriva probleme vojaške privatizacije.

Mockaitis omenja predvsem dve ravni, za kateri bi se odločevalci morali zavedati, kaj pomeni vladna pogodba z zasebnim vojaško-varnostnim podjetjem: raven nadzora in raven zakonodaje. Nadzor je otežen, saj pogodb z zasebniki ne sklepa samo ministrstvo za obrambo, temveč jih podpisujejo tudi druge vladne agencije. Nadzor tako ni mogoč z ene točke, oteženo pa je tudi usklajevanje vseh ameriških udeležencev v operaciji. Glede mednarodne zakonodaje in tudi domačih zakonodaj (ameriške in zakonodaje države, v kateri poteka operacija) pa avtor ugotavlja, da 
imajo pripadniki zasebnih vojaško-varnostnih podjetij skoraj kazensko imuniteto. Povsem jasno postane, tako iz dela Mockaitisa kot iz drugih virov, da morajo biti tudi vojaki seznanjeni s problematiko vključevanja pripadnikov zasebnih vojaškovarnostnih podjetij $\mathrm{v}$ operacijo. Kajti za sodelovanje nacionalne vojske (kot zanimivost: Mockaitis piše besedo vojaki, kadar ima v mislih vojake nacionalnih vojsk, z veliko začetnico, torej Vojaki) in pogodbenikov so nujna določena skupna izhodišča. Vojaška usposobljenost je pri tem še najmanj težavna, saj so pripadniki zasebnih vojaško-varnostnih podjetij običajno dobro usposobljeni in vojaško izkušeni. Iz vrste incidentov lahko sklepamo, da predstavljajo pogodbeniki tveganje sami po sebi, saj se pogosto ne držijo načela najmanjše možne uporabe sile, temveč se zelo hitro zapletejo v oborožen incident. Sodelovanje nacionalne vojske s takšnimi strukturami ne samo, da neposredno ogroža varnost vojakov, temveč poslabša odnos lokalnega prebivalstva do vseh prisotnih oboroženih sil. Namesto da bi pogodbeniki pripomogli k uspehu operacije, njen uspeh ogrožajo. Mockaitis sicer poudari, da ne moremo enačiti vseh pogodbenikov. Veliko jih opravlja svoje delo dobro in profesionalno. Žal pa incidenti, ki jih naredi manjšina (kot posebno težavno se je izkazalo podjetje Blackwater), mečejo slabo luč na vsa zasebna vojaško-varnostna podjetja.

V sklepu svojega sicer za tako zanimivo in aktualno problematiko kratkega dela (64 strani) Mockaitis povzame izkušnje iz delovanja zasebnih vojaško-varnostnih podjetij v Iraku in Afganistanu ter predstavi nekaj priporočil, ki bi jih bilo dobro upoštevati pri najemanju teh podjetij za opravljanje vojaškega dela. 
Maja Garb

\section{PROBLEMS OF MILITARY SECURITY CONTRACTORSHIP IN IRAQ AND AFGHANISTAN}

The issue of military privatization, where we refer both to the privatization of military supply and the privatization of military activities in general, has been very topical, especially in the period of Iraq War, which started in 2003, and later. Various private military companies had, of course, been active even before that (e.g. currently inactive companies Executive Outcomes and Sandline International) and external contractors have been increasingly providing for military supply ever since the introduction of the professional soldier recruitment. Nevertheless, Private Military Security Contractors (PMSCs) spread substantially during the topical conflicts in Iraq and Afghanistan. The work by Thomas R. Mockaitis Soldiers of Misfortune? (Strategic Studies Institute and U.S. Army War College Press, May 2014. ISBN 1-58487613-1) presents the functioning of PMSCs in the above-mentioned conflicts, while focusing on the issue of armed contractors. The author finds that, generally, logistics activities (troop housing and facilities, food service operations, laundry operations etc.) do not represent a problem when carried out by contractors. Armed members of PMSCs participating in U.S. operations are, however, something different. Based on the official reports, the author gives account of some of the most exposed incidents and problems (too early and unnecessary firing during armed escorting, inclusion of local contractors, paying warlords for smooth passage, the culture of impunity etc.), thus brutally revealing the problems of military privatization.

Mockaitis mentions two main levels where decision-makers should pay attention to what a government contract with a PMSC means: i.e. control level and legislation level. Control is difficult, since contracts with private companies are not concluded only by the Department of Defense, but also by other government agencies. It is thus impossible to ensure control from one single point, and difficult to coordinate all U.S. stakeholders involved in operations. As far as international and national (U.S. and the country where the operation is taking place) legislations are concerned, the 
author establishes that PMSC members virtually enjoy immunity from prosecution. It becomes perfectly clear, both, from the Mockaitis' monograph as well as from other sources that the military as well should be familiar with the problem of PMSC members' participation in operations. The cooperation of national armed forces (an interesting fact is that Mockaitis capitalizes the word Soldier when referring to members of national armed forces) and contractors necessarily requires certain common bases. In this respect, military competence represents the least of a problem, since PMSC members are usually well-trained and have military experience. It can be established on the basis of a number of incidents that contractors in themselves represent a risk, since they do not abide by the principle of the minimum use of force and very quickly become involved in an armed conflict. The cooperation of national military with such entities does not only pose a direct threat to soldiers, but also worsens the attitude of the local population towards the armed forces in the area. Instead of contributing to the success of the operation, the contractors threaten its success. Mockaitis, however, underlines that all contractors cannot be equated. A number of them do a good and professional job. Nevertheless, the incidents provoked by the minority (Blackwater has proved to be an especially notorious company) reflect unfavorably on all PMSCs.

In the conclusion of his monograph, which is short, though, (64 pages) considering the topicality and appeal of the discussed problem, Mockaitis recaps the experiences drawn from the functioning of military security companies in Iraq and Afghanistan and provides a few recommendations which would be good to take into consideration when hiring these companies to do military work. 
Slikovno gradivo

\section{Photos}


Jože Rozman: VOJAŠKOGEOGRAFSKA RAZSEŽNOST DOBRUDŽE IN (SLOVENSKI) PROSTOVOLCI NA TEM

Slika 1:

Reliefni hrbti

nad dolinami

Vir:

Z. Bratun, april

2014

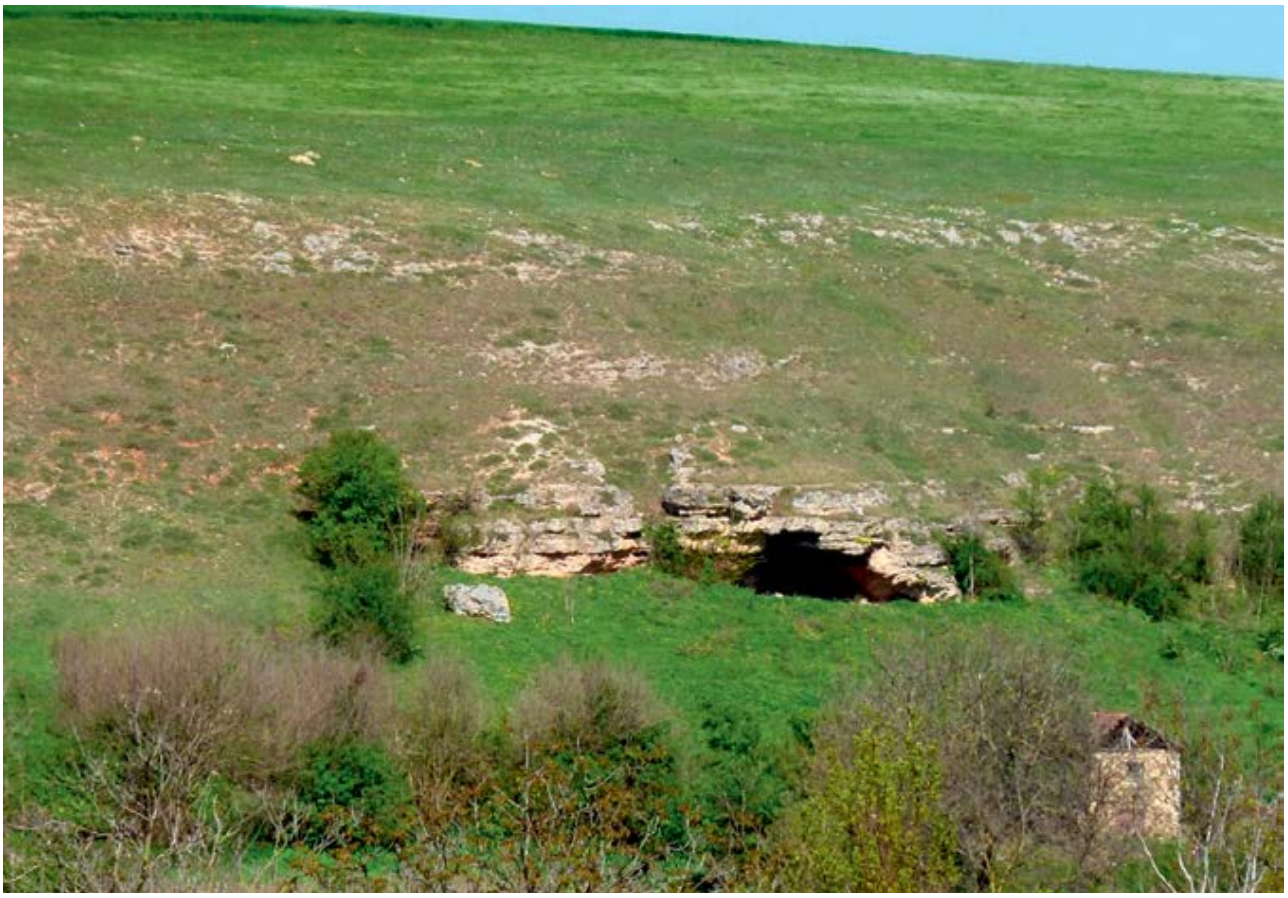

Slika 2:

Erozijska in odsekana obala južne Dobrudže

Vir:

Z. Bratun, april 2014

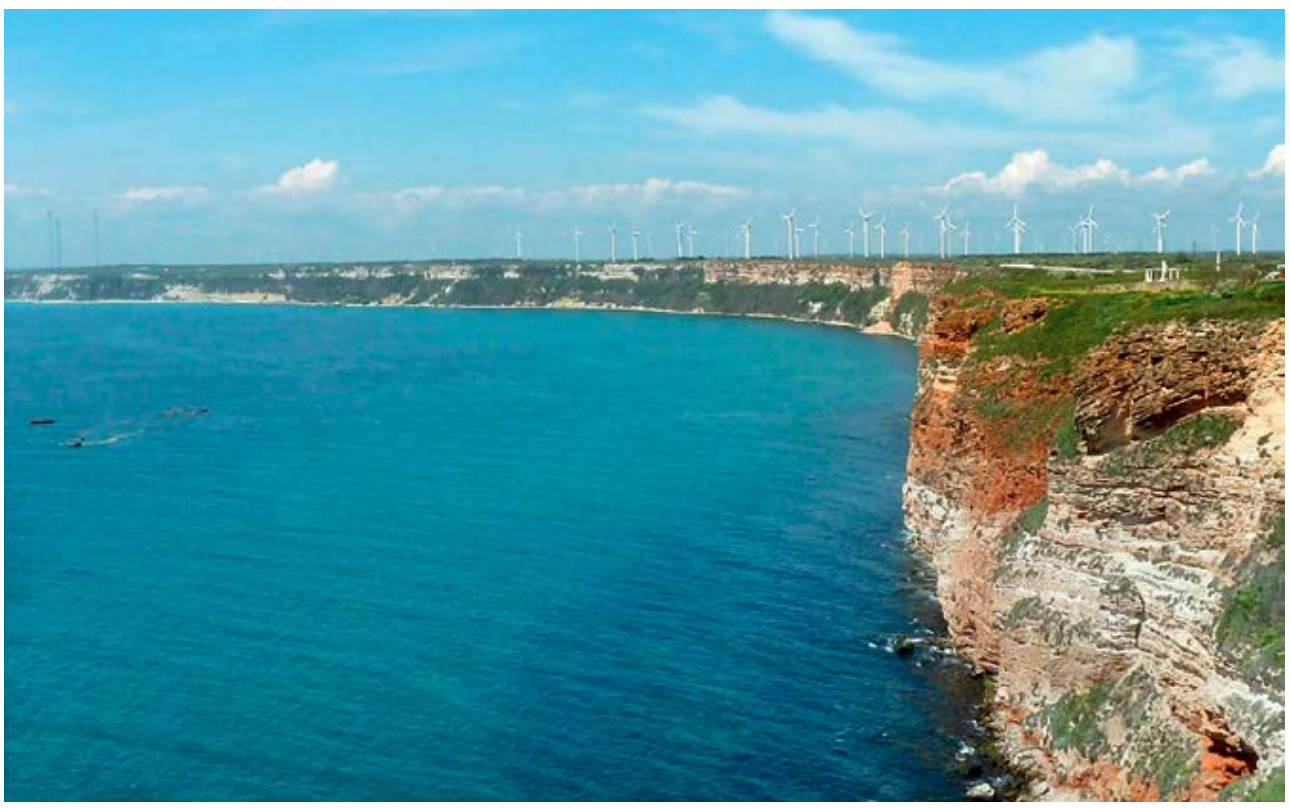


Slika 3: Postroj častnikov 1. srbske dobrovoljske divizije in obisk carja Nikolaja II., junij 1916 Vir:
Ratni album 1914-1918

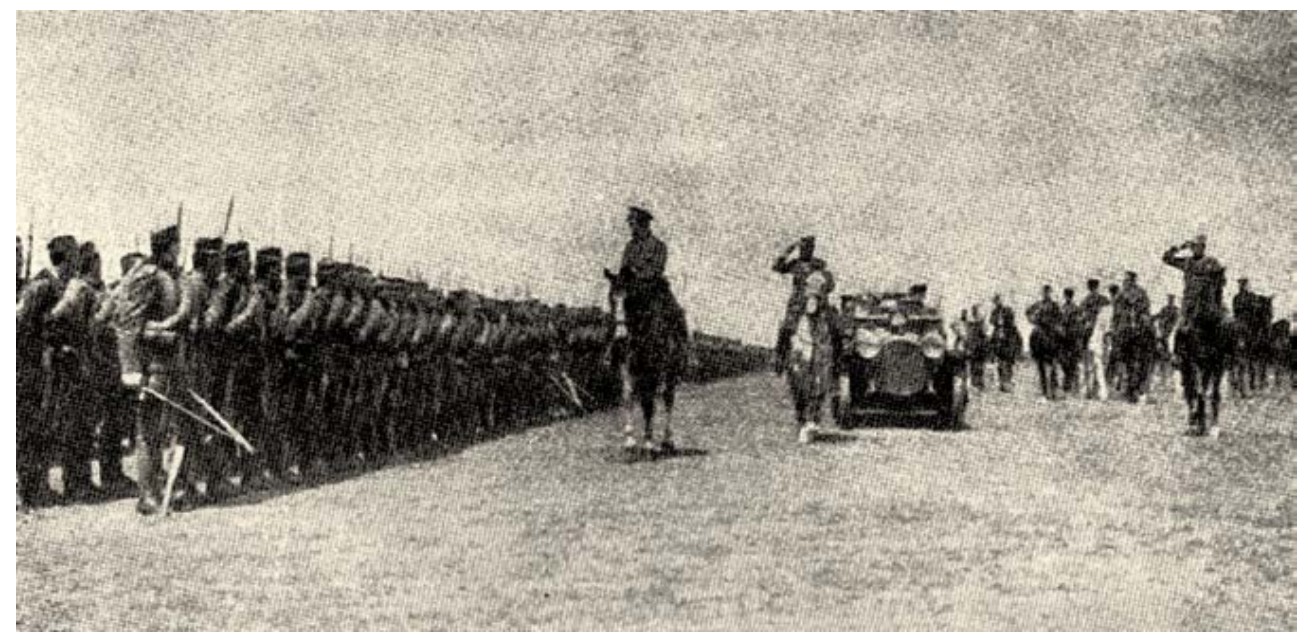

Slika 4: Prostovoljci na ladjah in vlačilcih na Donavi pri kraju Reni, poleti 1916 Vir:
Ratni album 1914-1918

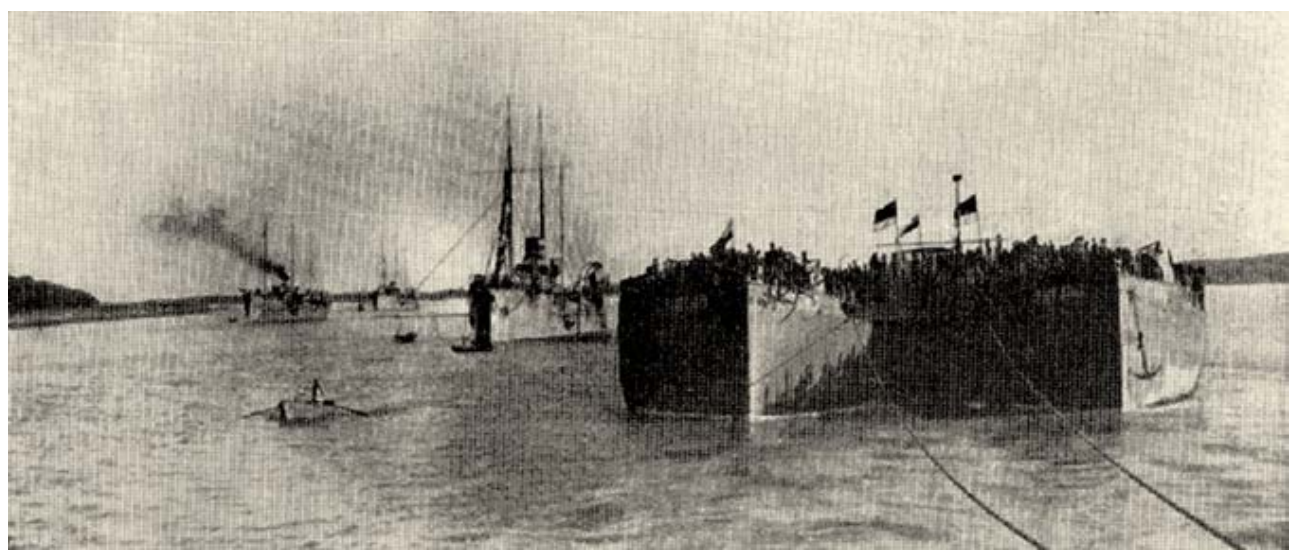


Slika 5:

Spomenik

padlim v mestu

Amzača

Z. Bratun, april

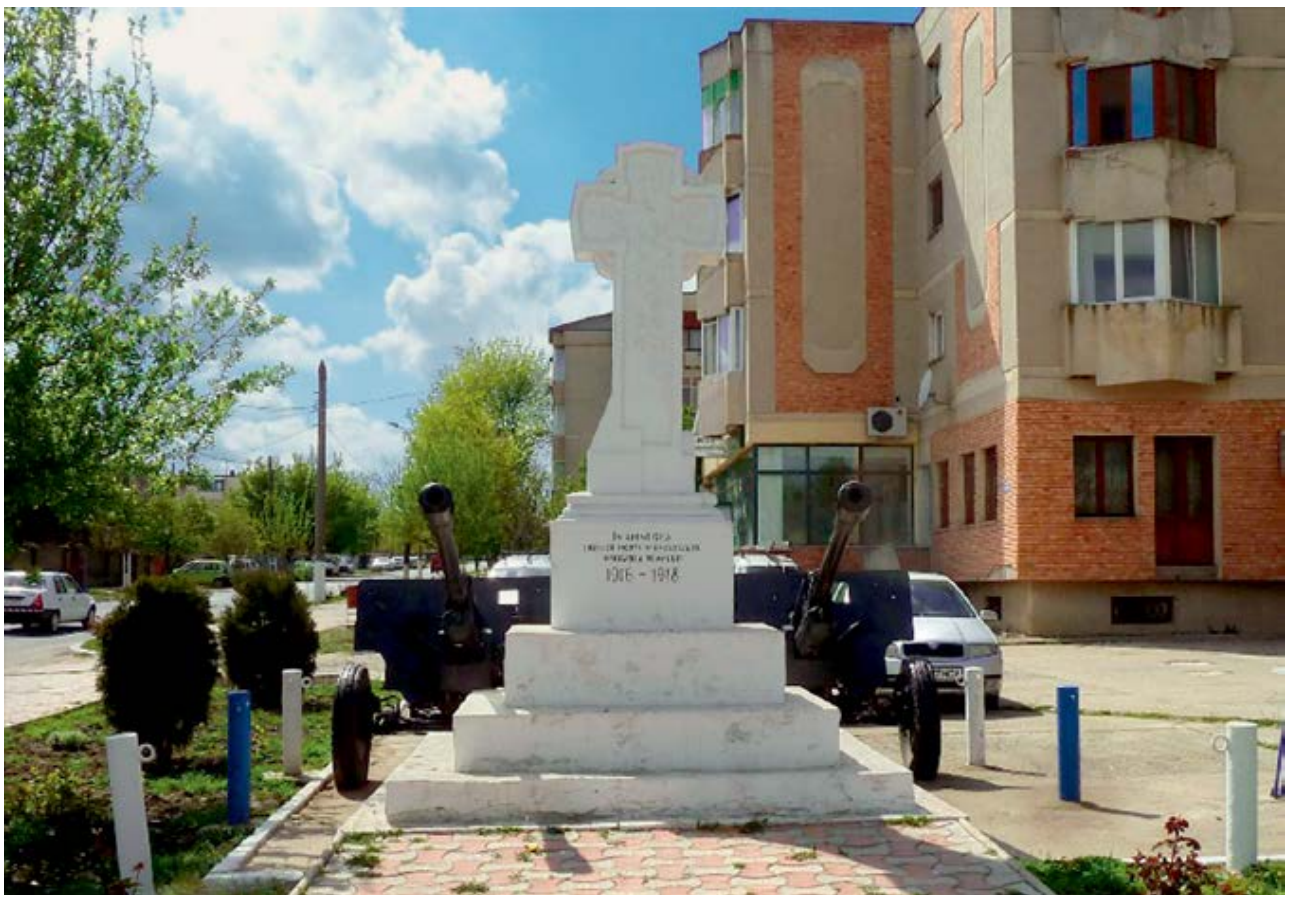

Slika 6:

Spomenik -

piramida na

pokopališču $v$

mestu Medgidia

Z. Bratun, april 2014

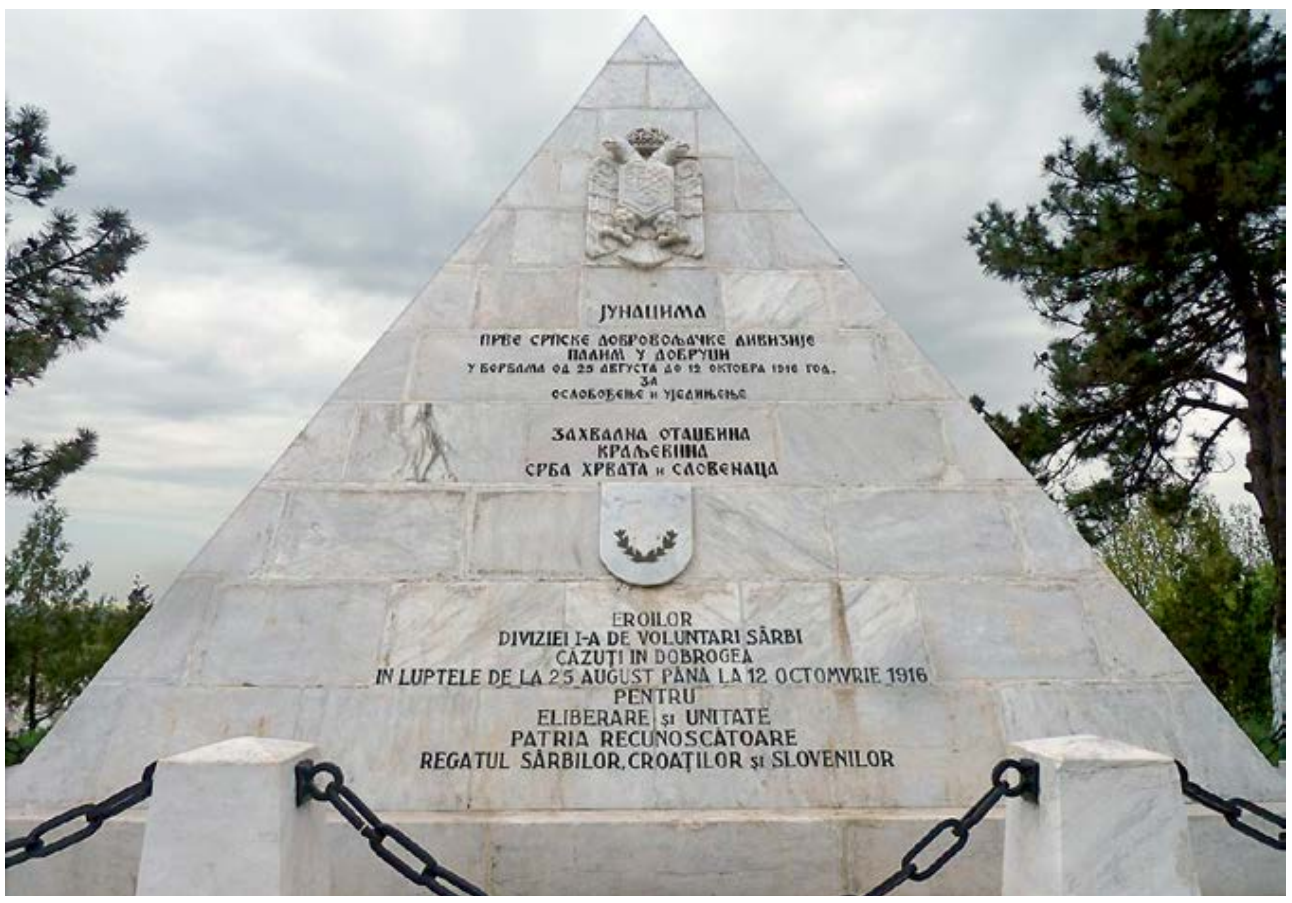


Slika 7: Shema bojev

1. srbske dobrovoljske divizije

(avgust-oktober 1916)

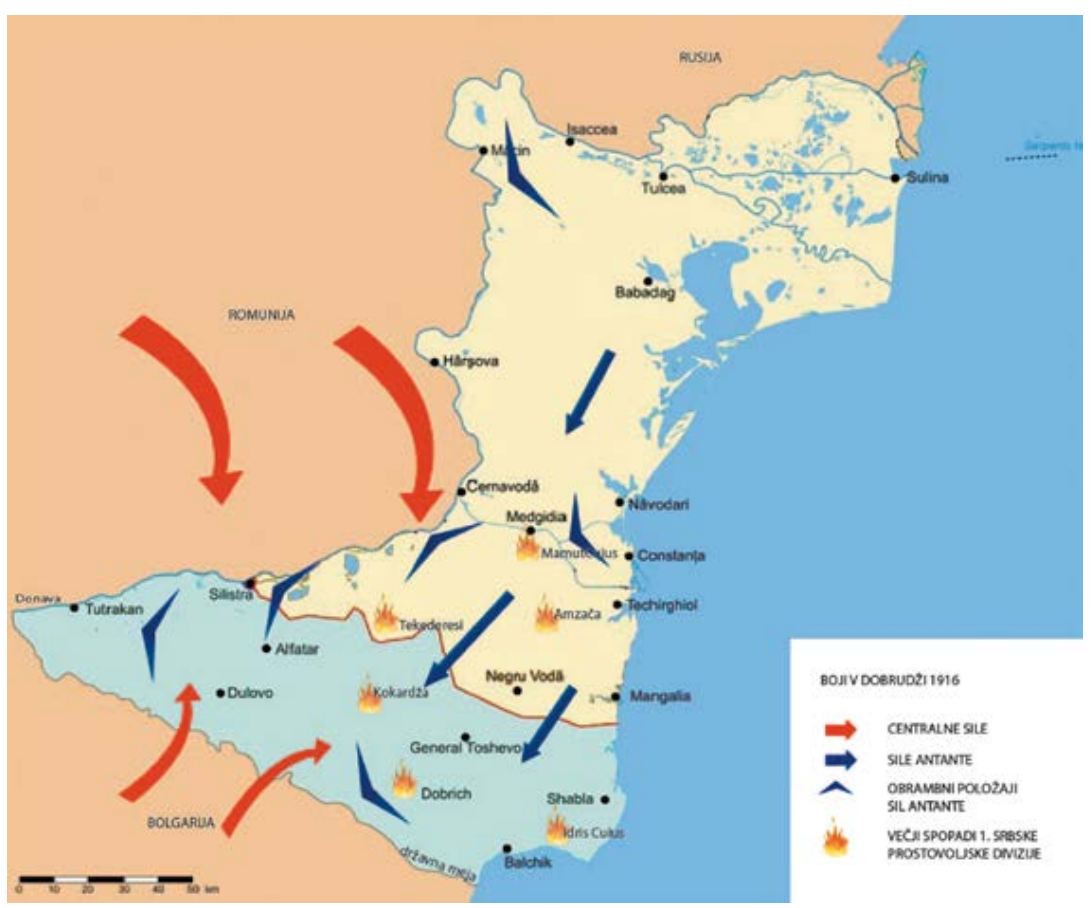



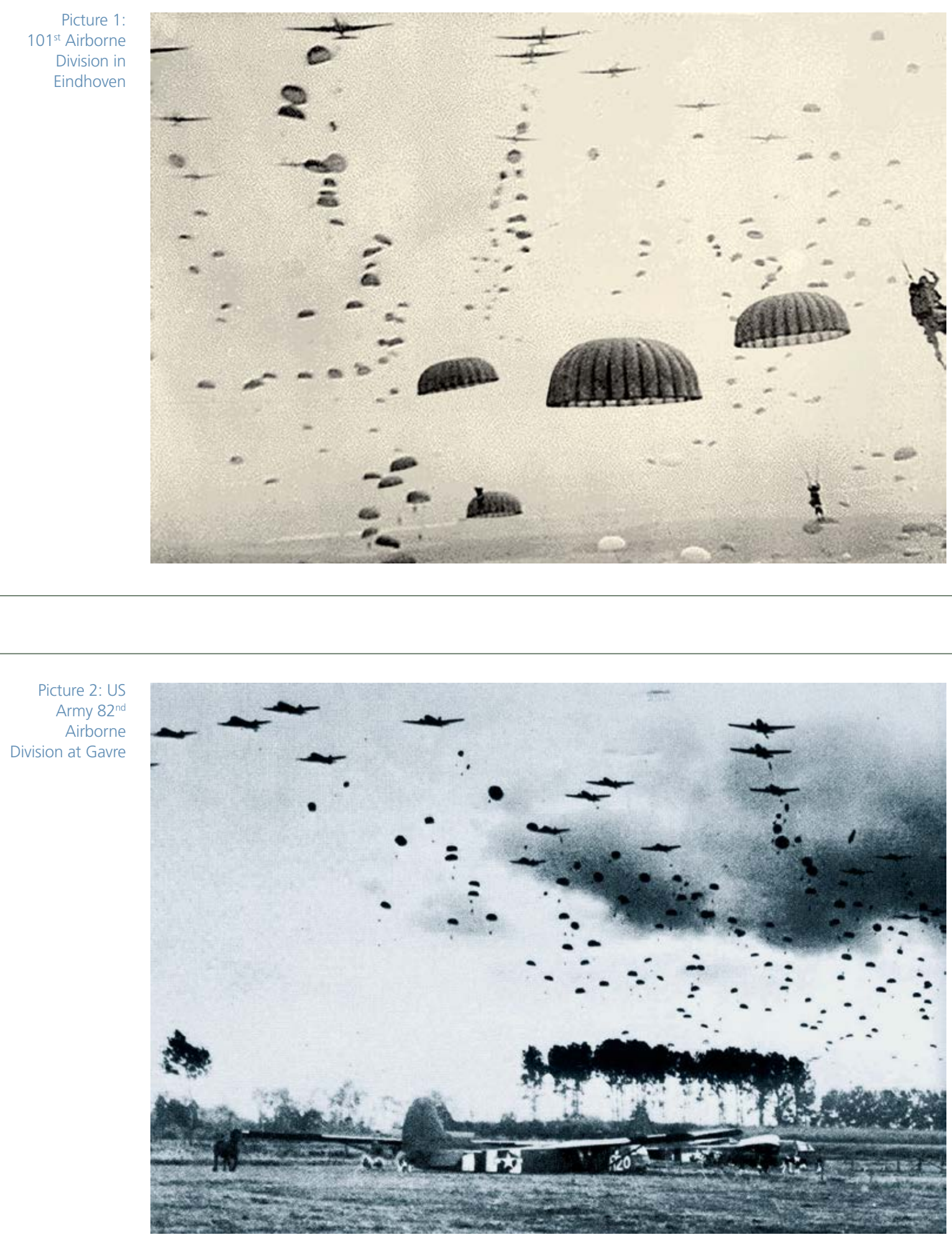
Picture 3: British

$1^{\text {st }}$ Airborne Division paratroopers before climbing into Airspeed Horsa gliders

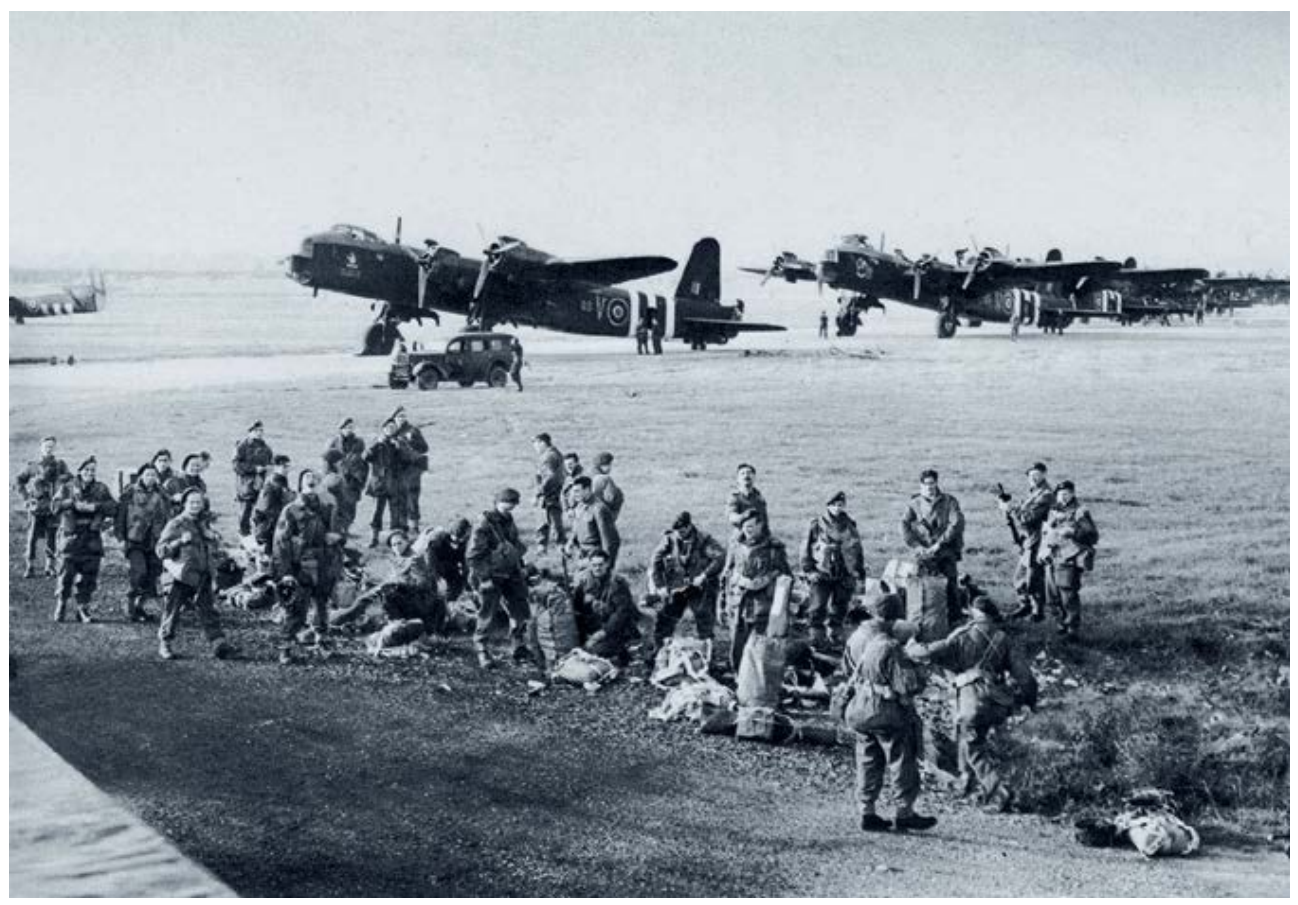

Arnhem Bridge

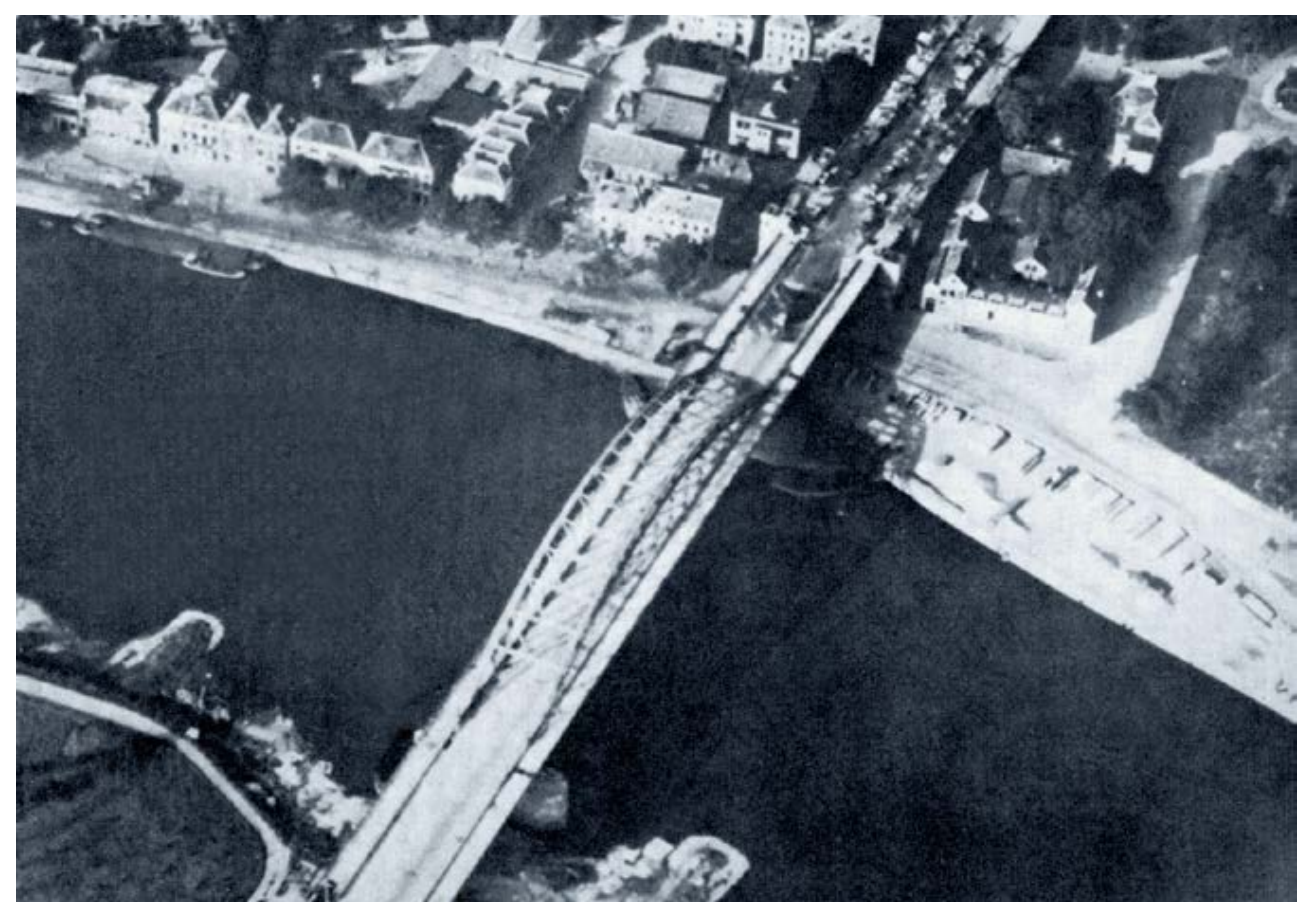


Picture 5:

Major General

Stanislaw

Sosabowski

(centre),

Commander

of the Polish

Parachute

Brigade

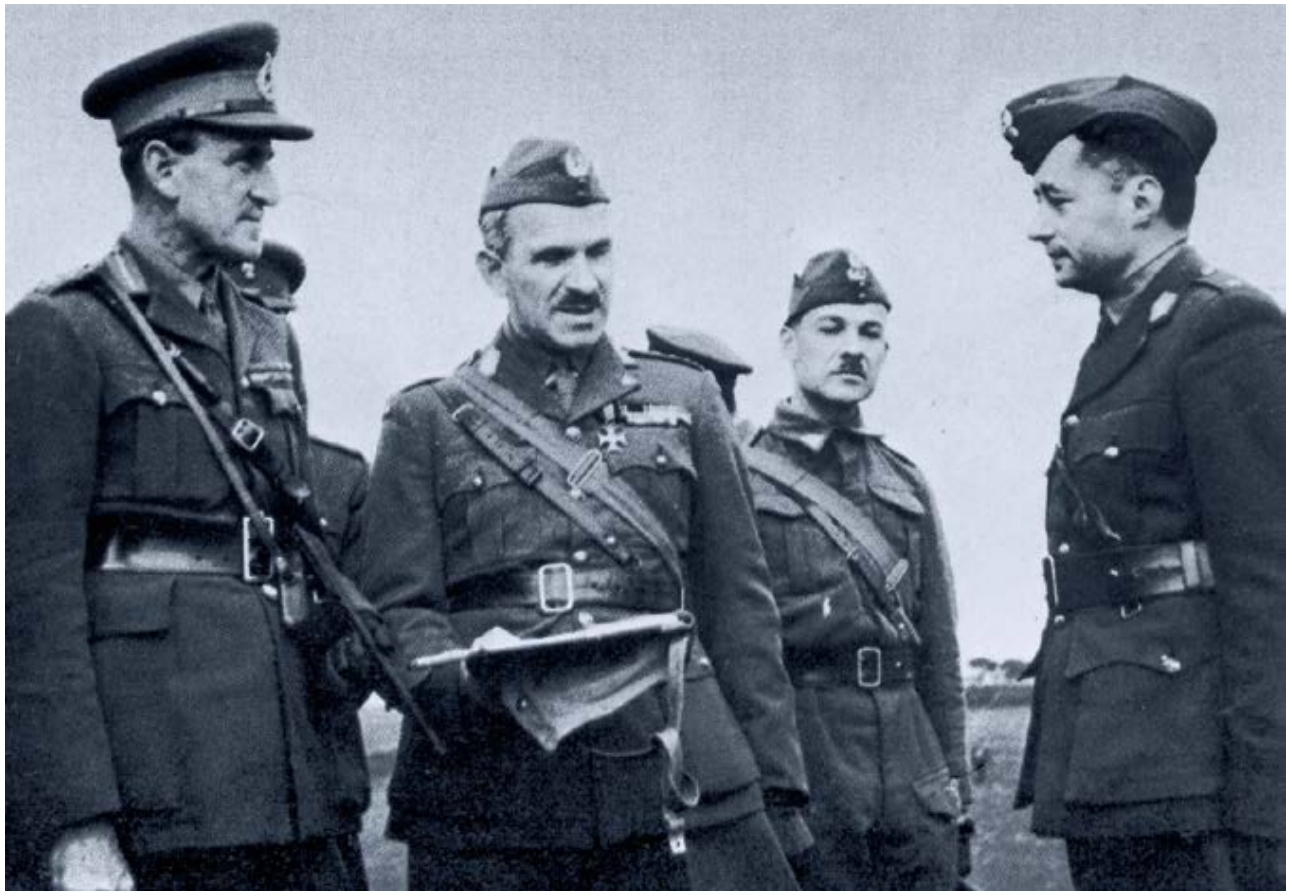

Note: The pictures are from the book Histoire des opérations aéroportèes, Brussels: Elsevier Sequoi, 1979,

the French edition, translated and adapted after Airborne Operations, London: Salamander Books Ltd. 1978. 
Avtorji

Authors 


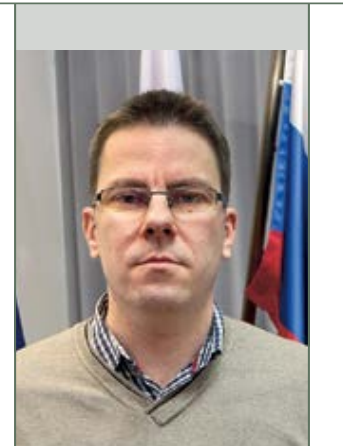

Mag. Uroš Tovornik je na Univerzi v Ljubljani leta 2001 diplomiral in leta 2005 magistriral iz politologije. Delovne izkušnje je od leta 2001 pridobival v zasebnem in javnem sektorju, doma in $\mathrm{v}$ tujini. Od leta 2006 je uslužbenec Ministrstva za obrambo. Sodeloval je pri predsedovanju Slovenije Svetu Evropske unije leta 2008 in delo nadaljeval v Obrambnem oddelku Stalnega predstavništva RS pri Natu kot pomočnik obrambnega svetovalca. Od tod je leta 2013 odšel na delo v Mednarodni sekretariat Nata v Bruslju.

Uroš Tovornik, MSc, holds Bachelor's (2001) and Master's (2005) degrees in political science from the University of Ljubljana, Slovenia. During his professional career, which started in 2001, he has been working in both private and public sectors, at national and international levels. In 2006, he joined the Ministry of Defence of Slovenia. Since then, he has been a member of the Ministry of Defence EU presidency team in 2008, assistant defence advisor within the Slovenian Defence Section at NATO Headquarters and, from mid-2013, part of the NATO International Staff in Brussels.

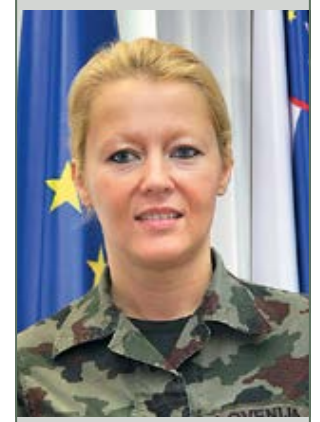

VVU XIII. razreda dr. Valerija Bernik je doktorirala iz zgodovine na Filozofski fakulteti Univerze v Ljubljani. V Slovenski vojski je zaposlena od leta 1997. V Centru za doktrino in razvoj je sodelovala $\mathrm{v}$ več različnih projektih, v Poveljstvu za doktrino, razvoj, izobraževanje in usposabljanje pa je vodila Oddelek vojaško-družboslovnih ved in športa. Trenutno je zaposlena na Katedri vojaških ved na Centru vojaških šol, na kateri se ukvarja predvsem z vojaško zgodovino.

Valerija Bernik

Valerija Bernik, Senior Military Specialist Class XIII, PhD, holds a PhD in history from the Faculty of Arts, University of Ljubljana. She has been a member of the Slovenian Armed Forces since 1997. As member of the then Doctrine and Development Centre, she participated in various projects and headed the Military and Social Sciences and Sports Section. Currently, she works in the Chair of Military Sciences of the Military Schools Centre, where she mainly deals with military history. 


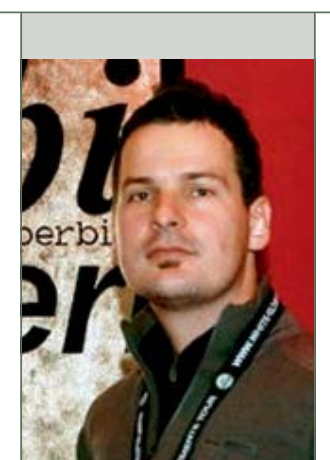

Jože Rozman

Jože Rozman je profesor sociologije in univerzitetni diplomirani politolog - obramboslovec. Področje njegovega raziskovalnega dela je vojaška zgodovina Slovencev v 20. stoletju. Kot avtor vojaškozgodovinskih prispevkov sodeluje z društvom GEOSS pri projektu Vranov let, ki ohranja spomin na sodelovanje slovenskih partizanov, aktivistov in prebivalcev $\mathrm{z}$ zavezniki. Leta 2013 je sodeloval pri nastanku zgodovinskoturistične karte o pohodu XIV. divizije med drugo svetovno vojno.

Jože Rozman is Professor of Sociology and holds a Bachelor's degree in Political Sciences - Defence Studies. As author of several military and history articles, he cooperates with the GEOSS association in the project Vranov let (Raven's Flight), which preserves the memory of the collaboration of Slovenian Partisans, activists and population with the Allies. In 2013, he participated in the preparation of a historic and tourist map of the $14^{\text {th }}$ Division's march in World War II.

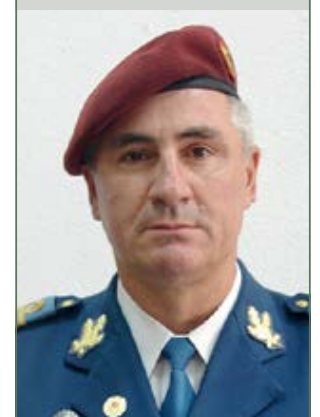

Polkovnik dr. Mircea Tănase je diplomiral na Akademiji za visoke vojaške študije v Bukarešti (1994) in na Fakulteti za zgodovino v Bukarešti (2002). Leta 2007 je doktoriral iz vojaških znanosti. Med vojaško kariero je opravljal različne štabne, poveljniške in pedagoške dolžnosti. Je glavni urednik zbornika Gândirea militară românească (Romunsko vojaško razmišljanje), ki ga izdaja Generalštab Romunskih oboroženih sil, in gostujoči profesor na Nacionalni obrambni univerzi Carol I. v Bukarešti ter na Akademiji kopenskih sil Nicolae Bălcescu v mestu Sibiu. Je avtor številnih knjig in člankov z zgodovinsko, vojaško, varnostno ter obrambno tematiko.

Colonel Mircea Tănase, PhD, graduated from the Academy of Higher Military Studies in Bucharest (1994) and the Faculty of History in Bucharest (2002). He holds a PhD in Military Science (2007). Throughout his military career, he has served in various staff, command and teaching positions. He is Editorin-Chief of the Gândirea militară românească (Romanian Military Thinking Journal) published by the Romanian Armed Forces General Staff and Adjunct Professor at the Carol I National Defence University, Bucharest, and Nicolae Bălcescu Land Forces Academy Sibiu. He has authored several books and articles on history, military, security and defence. 


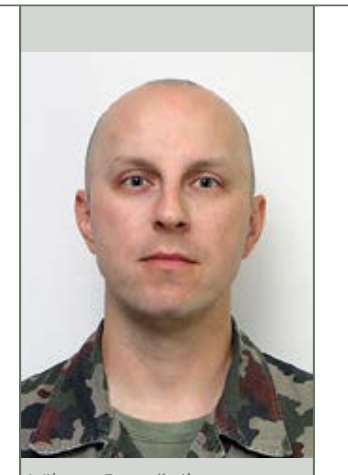

Stotnik Viktor Potočnik je v SV zaposlen od leta 2001. Do zdaj je opravljal več različnih dolžnosti. Sodeloval je $\mathrm{v}$ operacijah Sforja $\mathrm{v} \mathrm{BiH}$ kot poveljnik motoriziranega voda in v operacijah Kforja na Kosovu kot vodja taktičnooperativnega centra. Leta 2011 je končal šolanje na poveljniško-generalštabni šoli Ameriške kopenske vojske in pridobil magisterij iz vojaške znanosti in umetnosti. Trenutno dela kot višji častnik za napredno planiranje v J5/GŠSV.

Captain Viktor Potočnik has worked in the SAF since 2001 and has since held a number of different positions. He has participated in SFOR operations in Bosnia and Herzegovina, acting as the Motorized Platoon Commander, and in KFOR operations in Kosovo as Head of the Tactical Operations Centre. In 2011, he graduated from the US Army Command and General Staff College (Master of Military Art and Science). He currently holds the position of a Senior Advanced Planning Officer at the Joint Strategic Planning Division (J5) at the SAF General Staff.

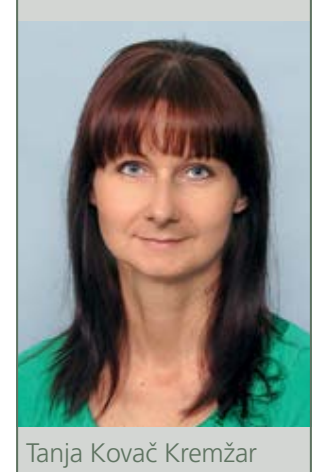

VVU X. razreda Tanja Kovač Kremžar, mag., je univerzitetna diplomirana biologinja. Magistrirala je na Fakulteti za varnostne vede. Na Ministrstvu za obrambo se je zaposlila leta 2003. Dve leti pozneje je bila napotena $\mathrm{V}$ MOM v Afganistan, kjer je v nemškem ROLE 3 opravljala laboratorijsko delo. Od leta 2011 dela v Vojaški zdravstveni enoti v odseku za laboratorijsko dejavnost. Področje, ki ga opisuje v članku, je del njenega magistrskega dela in vsebina, s katero se srečuje pri svojem delu.

Tanja Kovač Kremžar, Senior Military Specialist Class X, MSc, holds a Bachelor's degree in biology and a Master's degree from the Faculty of Criminal Justice and Security. She joined the Ministry of Defence in 2003. Two years later, she was deployed to an international operation in Afghanistan, where she worked in the laboratory of German ROLE 3 unit. Since 2011, she has worked in the Laboratory Detachment of the Military Medical Unit. The subject discussed in the article is a part of her Master's thesis and deals with the content she encounters during her work. 


\section{Navodila avtorjem za oblikovanje prispevkov Instructions for the authors of papers}




\section{NAVODILA AVTORJEM ZA OBLIKOVANJE PRISPEVKOV ZA SODOBNE VOJAŠKE IZZIVE IN VOJAŠKOŠOLSKI ZBORNIK}

\section{Vsebinska navodila}

Splošno

Sodobni vojaški izzivi je interdisciplinarna znanstveno-strokovna publikacija, ki objavlja prispevke o aktualnih temah, raziskavah, znanstvenih in strokovnih razpravah, tehničnih ali družboslovnih analizah z varnostnega, obrambnega in vojaškega področja.

Vojaškošolski zbornik je vojaškostrokovna in informativna publikacija, namenjena izobraževanju in obveščanju o dosežkih ter izkušnjah na področju vojaškega izobraževanja, usposabljanja in izpopolnjevanja.

Kaj objavljamo?

Objavljamo prispevke v slovenskem jeziku s povzetki, prevedenimi v angleški jezik, in po odločitvi uredniškega odbora prispevke v angleškem jeziku s povzetki, prevedenimi v slovenski jezik.

Objavljamo prispevke, ki še niso bili objavljeni ali poslani v objavo drugi reviji. Pisec je odgovoren za vse morebitne kršitve avtorskih pravic. Če je bil prispevek že natisnjen drugje, poslan v objavo ali predstavljen na strokovni konferenci, naj to avtor sporočiti uredniku in pridobiti soglasje založnika (če je treba) ter navesti razloge za ponovno objavo.

\section{Tehnična navodila}

Omejitve dolžine prispevkov

Recenzije Prispevki se recenzirajo. Recenzija je anonimna. Glede na oceno recenzentov uredniški odbor ali urednik prispevek sprejme, če je treba, zahteva popravke ali ga zavrne. Pripombe recenzentov avtor vnese v prispevek.

Zaradi anonimnega recenzentskega postopka je treba prvo stran in vsebino oblikovati tako, da identiteta avtorja ni prepoznavna.

Avtor ob naslovu prispevka napiše, v katero kategorijo po njegovem mnenju in glede na klasifikacijo v COBISS spada njegov prispevek. Klasifikacija je dostopna na spletni strani revije in pri odgovornem uredniku. Končno klasifikacijo določi uredniški odbor. 
Lektoriranje Lektoriranje besedil zagotavlja OE, pristojna za založniško dejavnost. Lektorirana besedila se avtorizirajo.

Prevajanje Prevajanje besedil ali povzetkov zagotavlja OE, pristojna za prevajalsko dejavnost oziroma Šola za tuje jezike Centra vojaških šol.

Navajanje Navajanje avtorjev je skrajno zgoraj, levo poravnano.

avtorjev Primer:

prispevka Ime 1 Priimek 1,

Ime 2 Priimek 2

V opombi pod črto se za slovenske avtorje navede, iz katere ustanove prihajajo. Pri tujih avtorjih je treba navesti tudi ime države.

Naslov Navedbi avtorjev sledi naslov prispevka. Črke v naslovu so velike 16 pik, natiprispevka snjene krepko, besedilo naslova pa poravnano na sredini.

Povzetek Prispevku mora biti dodan povzetek, ki obsega največ 1200 znakov (20 vrstic). Povzetek naj na kratko opredeli temo prispevka, predvsem naj povzame rezultate in ugotovitve. Splošne ugotovitve in misli ne spadajo v povzetek, temveč v uvod.

Povzetek Avtorji morajo oddati tudi prevod povzetka v angleščino. Tudi za prevod povzetka v angleščini velja omejitev do 1200 znakov (20 vrstic).

Ključne Ključne besede (3-5, tudi $\mathrm{v}$ angleškem jeziku) naj bodo natisnjene krepko in $\mathrm{z}$ besede obojestransko poravnavo besedila.

Besedilo Avtorji naj oddajo svoje prispevke na papirju formata A4, s presledkom med vrsticami 1,5 in velikostjo črk 12 pik Arial. Na zgornjem in spodnjem robu naj bo do besedila približno $3 \mathrm{~cm}$, levi rob naj bo širok $2 \mathrm{~cm}$, desni pa $4 \mathrm{~cm}$. Na vsaki strani je tako približno 30 vrstic s približno 62 znaki. Besedilo naj bo obojestransko poravnano, brez umikov na začetku odstavka.

Kratka Avtorji morajo pripraviti kratko predstavitev svojega strokovnega oziroma znanpredstavitev stvenega dela. Predstavitev naj ne presega 600 znakov (10 vrstic, 80 besed). Če avtorjev je avtorjev več, se predstavi vsak posebej, čim bolj zgoščeno. Avtorji naj besedilo umestijo na konec prispevka po navedeni literaturi. 
Struktu- $\quad$ Posamezna poglavja v besedilu naj bodo ločena s samostojnimi podnaslovi in riranje besedila ustrezno oštevilčena (členitev največ na 4 ravni).

Primer:

1 Uvod

2 Naslov poglavja (1. raven)

2.1 Podnaslov (2. raven)

2.1.1 Podnaslov (3. raven)

2.1.1.1 Podnaslov (4. raven)

Oblikovanje V seznamu literature je treba po abecednem redu navesti le avtorje, na katere seznama se sklicujete $\mathrm{v}$ prispevku, celotna oznaka vira pa mora biti skladna s harvardliterature skim načinom navajanja. Če je avtorjev več, navedemo vse, kot so navedeni na izvirnem delu.

Primeri:

a) knjiga:

Priimek, ime (lahko začetnica imena), letnica. Naslov dela. Kraj: Založba.

Na primer:Urlich, W., 1983. Critical Heuristics of Social Planning. Chicago: University of Chicago Press.

b) zbornik:

Samson, C., 1970. Problems of information studies in history. V S. Stone, ur. Humanities information research. Sheffield: CRUS, 1980, str./pp. 44-68. Pri posameznih člankih v zbornikih na koncu posameznega vira navedemo strani, na katerih je članek, na primer:

c) članek v reviji

Kolega, N., 2006. Slovenian coast sea flood risk. Acta geographica Slovenica. 46-2, str. $143-167$.

Navajanje Vse reference se začenjajo enako kot pri natisnjenih virih, le da običajnemu delu virov $\mathbf{z}$ interneta sledi še podatek o tem, kje na internetu je bil dokument dobljen in kdaj. Podatek o tem, kdaj je bil dokument dobljen, je pomemben zaradi pogostega spreminjanja www okolja.

Urlich, W., 1983. Critical Heuristics of Social Planning. Chicago: University of Chicago Press, str. 45-100. http://www.mors.si/index.php?id=213, 17. 10. 2008. Pri navajanju zanimivih internetnih naslovov v besedilu (ne gre za navajanje posebnega dokumenta) zadošča navedba naslova (http://www.vpvs.uni-lj.si). Posebna referenca na koncu besedila $\mathrm{v}$ tem primeru ni potrebna. 
Sklicevanje na vire

Slike, diagrami in tabele
Opombe pod črto

Kratice

Format zapisa prispevka
Pri sklicevanju na vire med besedilom navedite le priimek prvega avtorja in letnico izdaje. Primer: ... (Smith, 1997) ...

Če dobesedno navajate del besedila, ga ustrezno označite z narekovaji, v oklepaju pa poleg avtorja in letnice navedite stran besedila, iz katerega ste navajali.

Primer: ... (Smith, 1997, str. 15) ...

Pri povzemanju drugega avtorja napišemo besedilo brez narekovajev, v oklepaju pa napišemo, da gre za povzeto besedilo. Primer: (po Smith, 1997, str. 15). Če avtorja navajamo $\mathrm{v}$ besedilu, $\mathrm{v}$ oklepaju navedemo samo letnico izida in stran (1997, str. 15).

Slike, diagrami in tabele v prispevku naj bodo v posebej pripravljenih datotekah, ki omogočajo lektorske popravke. V besedilu mora biti jasno označeno mesto, kamor je treba vnesti sliko. Skupna dolžina prispevka ne sme preseči dane omejitve.

Če avtor iz tehničnih razlogov grafičnih dodatkov ne more oddati v elektronski obliki, je izjemoma sprejemljivo, da slike priloži besedilu. Avtor mora $\mathrm{v}$ tem primeru na zadnjo stran slike napisati zaporedno številko in naslov, v besedilu pa pustiti dovolj prostora zanjo. Prav tako mora biti besedilo opremljeno z naslovom in številčenjem slike. Diagrami se štejejo kot slike. Vse slike in tabele se številčijo. Številčenje poteka enotno in ni povezano s številčenjem poglavij. Naslov slike je naveden pod sliko, naslov tabele pa nad tabelo. Navadno je v besedilu navedeno vsaj eno sklicevanje na sliko ali tabelo. Sklic na sliko ali tabelo je: ... (slika 5) ... (tabela 2$) \ldots$

Primer slike: $\quad$ Primer tabele:

Tabela 2: Naslov tabele

Slika 5: Naslov slike

Številčenje opomb pod črto je neodvisno od strukture besedila in se v vsakem prispevku začne s številko 1. Posebej opozarjamo avtorje, da so opombe pod črto namenjene pojasnjevanju misli, zapisanih v besedilu, in ne navajanju literature.

Kratice naj bodo dodane v oklepaju, ko se okrajšana beseda prvič uporabi, zato posebnih seznamov kratic ne dodajamo. Za kratico ali izraz v angleškem jeziku napišemo najprej slovensko ustreznico, v oklepaju pa angleški izvirnik in morebitno angleško kratico.

Uredniški odbor sprejema prispevke, napisane z urejevalnikom besedil MS Word, izjemoma tudi v besedilnem zapisu (text only). 
Naslov Prispevkom naj bosta dodana avtorjeva naslov in internetni naslov ali telefonska avtorja številka, na katerih bo dosegljiv uredniškemu odboru.

Kako poslati Na naslov uredništva ali članov uredniškega odbora je treba poslati tiskano in eleprispevek ktronsko različico prispevka.

Potrjevanje Uredniški odbor avtorju pisno potrdi prejetje prispevka. Avtorjem, ki sporočijo sprejetja tudi naslov svoje elektronske pošte, se potrditev pošlje po tej poti.

prispevka

Korekture Avtor opravi korekture svojega prispevka v treh dneh.

Naslov Ministrstvo za obrambo

uredniškega Generalštab Slovenske vojske

odbora Sodobni vojaški izzivi

Uredniški odbor

Vojkova cesta 55

1000 Ljubljana

Slovenija

Elektronski naslov

Odgovorna urednica:

liliana.brozic@mors.si

Prispevkov, ki ne bodo urejeni skladno s tem navodilom, uredniški odbor ne bo sprejemal. 


\section{INSTRUCTIONS FOR THE AUTHORS OF PAPERS FOR THE CONTEMPORARY MILITARY CHALLENGES AND THE MILITARY EDUCATION JOURNAL}

\section{Content-related instructions}

General The Contemporary Military Challenges is an interdisciplinary scientific expert magazine, which publishes papers on current topics, researches, scientific and expert discussions, technical or social sciences analysis from the field of security, defence and the military..

The Military Education Journal is a military professional and informative publication intended for education and informing on achievements and experiences in the field of military education, training and improvement.

What do we publish?

We publish papers in Slovene with abstracts translated into English. If so decided by the Editorial Board, we also publish papers in English with abstracts translated into Slovene.

We publish papers, which have not been previously published or sent to another magazine for publication. The author is held responsible for all possible copyright violations. If the paper has already been printed elsewhere, sent for publication or presented at an expert conference, the author must notify the editor, obtain the publisher's consent (if necessary) and indicate the reasons for republishing.

\section{Technical instructions}

Limitations The papers should consist of 16 typewritten double-spaced pages or 30,000 charegarding racters. At a minimum they should have 8 pages or 15,000 characters and at a the length of the maximum 24 pages or 45,000 characters.

papers 
Reviews All papers are reviewed. The review is anonymous. With regard to the reviewer's assessment, the Editorial Board or the editor accepts the paper, demands modifications, if necessary, or rejects it. Upon receiving the reviewers' remarks, the author inserts them into the paper.

Due to an anonymous review process, the first page must be designed in the way that the author's identity cannot be recognized.

Next to the title, the author should indicate the category the paper belongs to according to him and according to the classification in the COBISS ${ }^{1}$. The classification is available on the magazine's internet page and at the responsible editor. The Editorial Board determines the final classification.

Proofreading The organizational unit responsible for publishing provides the proofreading of the papers. The proofread papers have to be approved.

Translating The translation of the papers or abstracts is provided by the organizational unit competent for translation or the School of Foreign Languages, Military Schools Centre.

Indicating The authors' name should be written in the upper left corner, aligned left.

the authors Example:

of the paper Name 1 Surname 1,

Name 2 Surname 2,

In the footnote, Slovenian authors should indicate the institution they come from. Foreign authors should also indicate the name of the state they come from.

Title of the The title of the paper is written below the listed authors. The font in the title is paper bold, size 16 points. The text of the title is centrally aligned.

Abstract The paper should have an abstract of a maximum 1,200 characters (20 lines). The abstract should include a short presentation of the topic, particularly the results and the findings. General findings and reflections do not belong in the abstract, but rather in the introduction.

Abstract in The authors must also submit the translation of the abstract into English. The translaEnglish tion of the abstract is likewise limited to a maximum of 1,200 characters (20 lines).

Key words Key words (3-5 also in the English language) should be bold with a justified text alignment.

Text

The authors should submit their papers on an A4 paper format, with 1.5 line spacing, fontArial size 12 points. At the upper and the bottom edge, there should be approx. $3 \mathrm{~cm}$ of space; the left margin should be $2 \mathrm{~cm}$ wide and the right margin $4 \mathrm{~cm}$. Each page consists of approx. 30 lines with 62 characters. The text should have a justified alignment, without indents at the beginning of the paragraphs. 
A brief pre- The authors should prepare a brief presentation of their expert or scientific work. sentation of The presentation should not exceed 600 characters (10 lines, 80 words). If there the authors are several authors, each should be presented individually, as shortly and as comprehensively as possible. These texts should be placed at the end of the paper, after the cited literature.

Text structuring

Individual chapters should be separated with independent subtitles and adequately numbered.

Example:

1 Introduction

2 Title of the chapter $\left(1^{\text {st }}\right.$ level $)$

2.1 Subtitle ( $\left.2^{\text {nd }} l e v e l\right)$

2.1.1 Subtitle $\left(3^{\text {rd }}\right.$ level $)$

2.1.1.1 Subtitle $\left(4^{\text {th }}\right.$ level $)$

Referencing In the bibliography, only the authors of references one refers to in the paper should be listed, in the alphabetical order. The entire reference has to be in compliance with the Harvard citing style.

Example:

Surname, name (can also be the initial of the name), year. Title of the work. Place. Publishing House.

\section{Example:}

Urlich, W., 1983. Critical Heuristics of Social Planning. Chicago: University of Chicago Press.

With certain papers published in journals, the author should indicate, at the end of each reference, a page on which the paper can be found.

\section{Example:}

Urlich, W., 1983. Critical Heuristics of Social Planning. Chicago: University of Chicago Press. pp. 45-100.

Referencing All references start the same as the references for the printed sources, only that internet sources the usual part is followed by the information about the Internet page on which the document was found as well as the date on which it was found. The information about the time that the document was found on the Internet is important, because the WWW environment changes constantly.

Urlich, W., 1983. Critical Heuristics of Social Planning. Chicago: University of Chicago Press. p. 45-100. http://www.mors.si/index.php?id=213, 17 October 2008.

When referencing interesting WWW pages in the text (not citing an individual document) it is enough to state only the Internet address (http://www.vpvs.uni-lj. si). A separate reference at the end of the text is therefore not necessary. 
Citing

Figures, diagrams, tables

Footnotes

Abbreviations

Format type of the paper
When citing sources in the text, indicate only the surname of the author and the year of publication. Example: ..... (Smith, 1997) ...

When making a direct reference to a text, the cited part should be adequately marked with quotation marks and followed by the exact page of the text which the citing is taken from.

Example: ...(Smith, 1997, p.15) ...

Figures, diagrams and tables in the paper should be prepared in separate files which allow for proofreading corrections. The place in the text where the picture should be inserted must be clearly indicated. The total length of the paper must not surpass the given limitation.

Should the author not be able to submit the graphical supplements in the electronic form due to technical reasons, it is exceptionally acceptable to enclose the figures to the text. In this case the author must write a sequence number and a title on the back of each picture and leave enough space in the text to include it. The text must likewise contain the title and the sequence number of the figure. Diagrams are considered figures.

All figures and tables are numbered. The numbering is not uniform and not linked with the numbering of the chapters. The title of the figure is stated beneath it and the title of the table is stated above it.

As a rule, the paper should include at least one reference to a figure or a table.. Reference to a figure or a table is: ... (Figure 5) (Table 2) .........

Example of a figure: $\quad$ Example of a table:

Table 2: Title of the table

Figure 5: Title of the figure

The numbering of the footnotes is not related to the structure of the text and starts with number 1 in each paper. We want to stress that the aim of the footnotes is to explain the thoughts written in the text and not to reference literature.

When used for the first time, the abbreviations in the text must be explained in parenthesis; therefore no additional list of abbreviations is needed. If the abbreviations or terms are written in English, the appropriate Slovenian term should be written along with the English original and possibly the English abbreviation in the parenthesis.

The Editorial Board accepts only the texts written with a MS Word text editor and only exceptionally those in the 'text only' format. 
Author's Each paper should include the author's address, e-mail or a telephone number, so address that the Editorial Board can reach him or her.

Sending A print or an electronic version of the paper should be sent to the address of the the paper Editorial Board or the members of the Editorial Board.

Confirma- The Editorial Board sends the author a written confirmation regarding the tion of the reception of the paper. The authors who also list their e-mails receive the confirreception of mation via e-mail.

the paper

Corrections The author makes corrections to the paper within three days.

$\begin{array}{ll}\text { Editorial } & \text { Ministry of Defence } \\ \text { Board } & \text { Slovenian Armed Forces } \\ \text { address } & \text { General Staff } \\ & \text { Contemporary Military Challenges } \\ & \text { Editorial Board } \\ & \text { Vojkova cesta 55 } \\ & \text { 1000 Ljubljana } \\ & \text { Slovenia } \\ & \text { Electronic address: } \\ & \text { Editor in Chief: } \\ & \text { liliana.brozic@mors.si }\end{array}$

The Editorial Board will not accept papers, which will not be in compliance with the above instructions. 



Sodobni vojaški izzivi - 16/št. 4

Vsebina

Liliana Brožič

UVODNIK: OB STOTI OBLETNICI ZAČETKA PRVE SVETOVNE VOJNE ALI SMO SE IZ KONFLIKTOV V ZADNJIH STO LETIH KAJ NAUČILI?

EDITORIAL: $100^{\text {TH }}$ ANNIVERSARY OF THE BEGINNING OF WORLD WAR I HAVE WE LEARNED ANYTHING FROM THE CONFLICTS IN THE PAST 100 YEARS

Uroš Tovornik ČAS OBLIKOVANJA NOVEGA SVETOVNEGA REDA THE TIME OF THE FORMATION OF A NEW WORLD ORDER

Valerija Bernik KEMIČNO OROŽJE - POSEBNOST PRVE SVETOVNE VOJNE ALI ŠE DANES PRETEČA NEVARNOST

CHEMICAL WEAPONS - PARTICULARITY OF WORLD WAR I OR A STILL IMMINENT DANGER

Jože Rozman VOJAŠKOGEOGRAFSKA RAZSEŽNOST DOBRUDŽE IN (SLOVENSKI) PROSTOVOLCI NA TEM BOJIŠČU V PRVI SVETOVNI VOJNI MILITARY GEOGRAPHICAL DIMENSION OF DOBROGEA AND (SLOVENIAN) VOLUNTEERS IN THIS BATTLEFIELD IN WORLD WAR I

Mircea Tănase »MARKET GARDEN« - THE EPIC AND THE TRAGEDY OF ALLIED PARATROOPERS IN THE NETHERLANDS

»MARKET GARDEN« - JUNAŠTVO IN TRAGEDIJA ZAVEZNIŠKIH PADALSKIH ENOT NA NIZOZEMSKEM

Viktor Potočnik

OBSEG IN KARAKTER SLOVENSKE VOJSKE SLOVENIAN ARMED FORCES SIZE AND CHARACTER

Tanja Kovač Kremžar VOJAŠKOMEDICINSKA OBVEŠČEVALNA DEJAVNOST Z OMEJENIMI VIRI NA PRIMERU MAJHNIH DRŽAV MILITARY MEDICAL INTELLIGENCE WITH LIMITED RESOURCES IN THE CASE OF SMALL COUNTRIES

Maja Garb PROBLEMI VOJAŠKO-VARNOSTNEGA POGODBENIŠTVA V IRAKU IN AFGANISTANU

PROBLEMS OF MILITARY SECURITY CONTRACTORSHIP IN IRAQ AND AFGHANISTAN 